Wask 215ts

$$
\text { LBRARY COPY }
$$

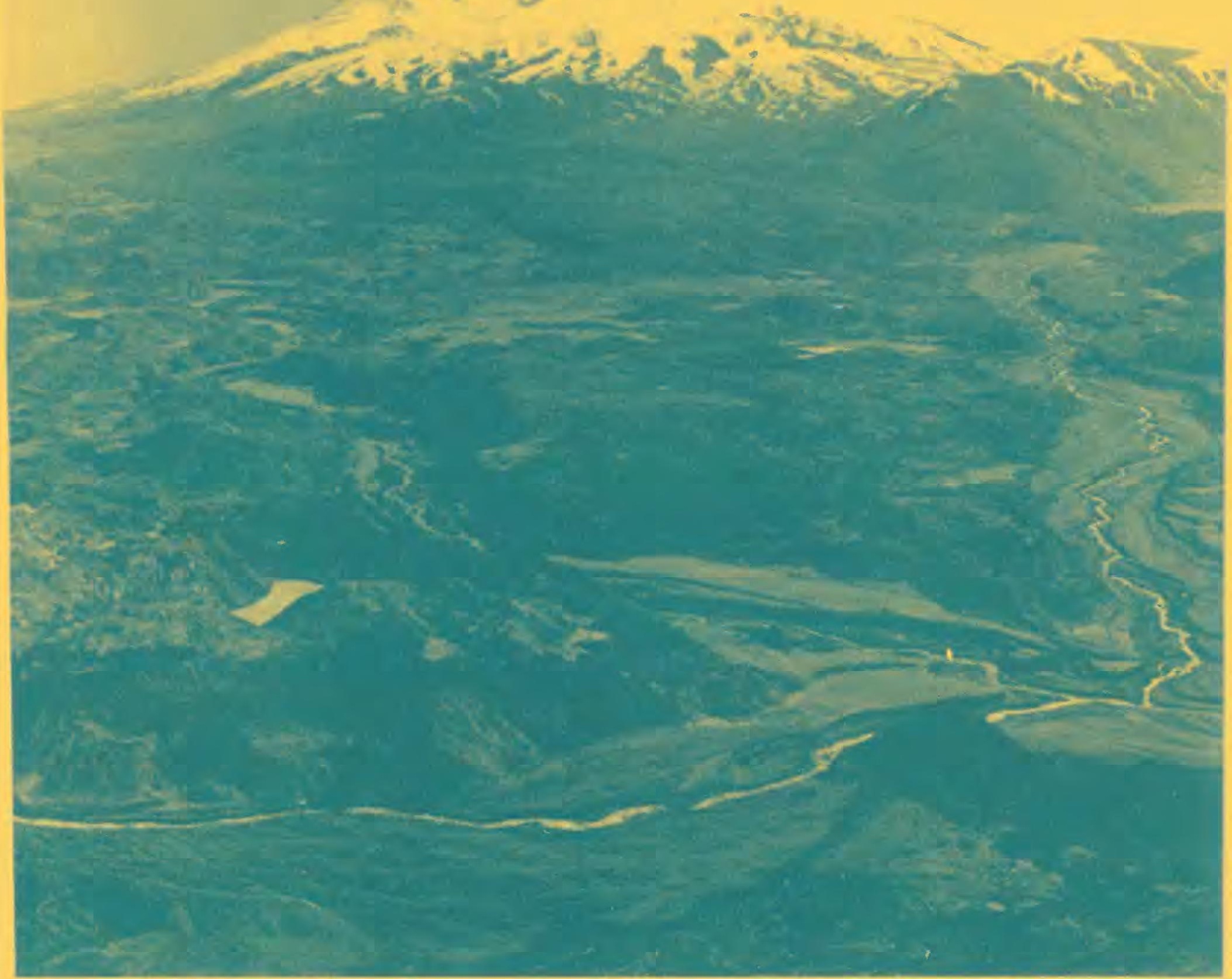

\title{
POST-ERUPTION CHANGES IN CHANNEL GEOMETRY OF STREAMS IN THE TOUTLE RIVER DRAINAGE BASIN, 1980-82, MOUNT ST. HELENS, WASHINGTON
}

United States Department of the Interior Geological Survey 
The May 18, 1980, eruption of Mount St. Helens, in southwest Washington State, drastically altered hydrologic and geomorphic conditions in an area of about $550 \mathrm{~km}^{2}$ around the volcano and along major streams draining the area. Volcanic events that severely modified watersheds include the lateral blast or pyroclastic density flow (Hoblitt and others, 1981; Moore and Sisson, 1981; Waitt and others, 1981), the debris avalanche in the upper North Fork Toutle Valley (Voight and others, 1981), pyroclastic flows (Rowley and others, 1981), and tephra deposition (Waitt and Dzurisin, 1981; Waitt and others, 1981). Additionally, lahars (volcanic mudflows or debris flows) flowed down all major streams originating on Mount St. Helens (Janda and others, 1981; Cummans, 1981; Pierson, 1982). Deposits from these events altered rainfal1-runoff relations, channel geometry, and the amount of sediment available to stream channels (Lisle and others, 1983; Martinson and Meyer, 1985), and in some cases created new surfaces with little or no through-flowing surface drainage (Meyer and Janda, 1985). The blast and airfall destroyed and damaged vegetation, eliminating or reducing transpiration over much of the affected area. Glaciers in the headwaters of most streams flanking the volcano were damaged or destroyed. Subsequent stream response to runoff and occasional volcanic events have produced erosion and deposition of a magnitude rarely observed elsewhere (Co11ins and others (1981; Lehre and others, 1981; Lisle and others, 1982; Martinson and Meyer, 1985; Meyer and Janda, 1985; Waitt and others, 1983).

To measure erosion, deposition, and changes in channel morphology that occur as the perturbed stream channels respond to altered conditions, monumented channel cross sections have been established along most of the river channels around Mount St. Helens. This report presents the cross-section data from the Toutle River drainage collected by the Water Resources Division, U.S. Geological Survey, Cascades Volcano Observatory, Vancouver, Washington, during water years 1980, 1981, and 1982.

We gratefully acknowledge the enthusiastic and diligent assistance of those who participated in data collection and reduction: Ronald Barnes, David Bice, Steven Brantley, Adam Burnett, Kenneth A. Cameron, John Ewert, Steven D. Finneran, Larry A. Freeman, Kevin C. Hadley, Hazel Hammond, Richard J. Janda, Richard L. Jesser, Jon J. Major, Patrice D. Mango, Donna C. Marron, William W. Mast, Patrick T. Pringle, Don S. Ropiequet, Martha Sabol, and Lyn J. Topinka. 


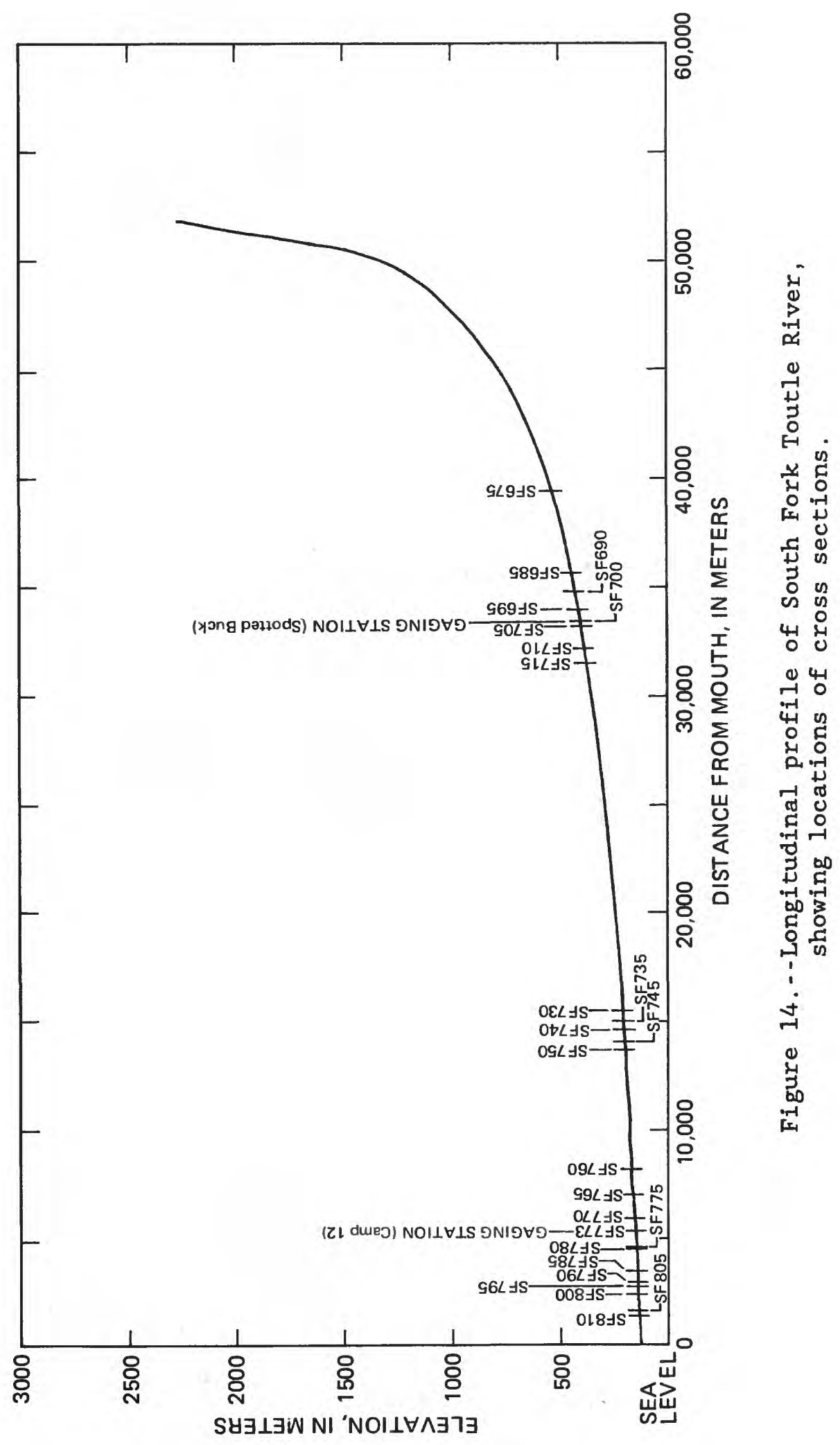



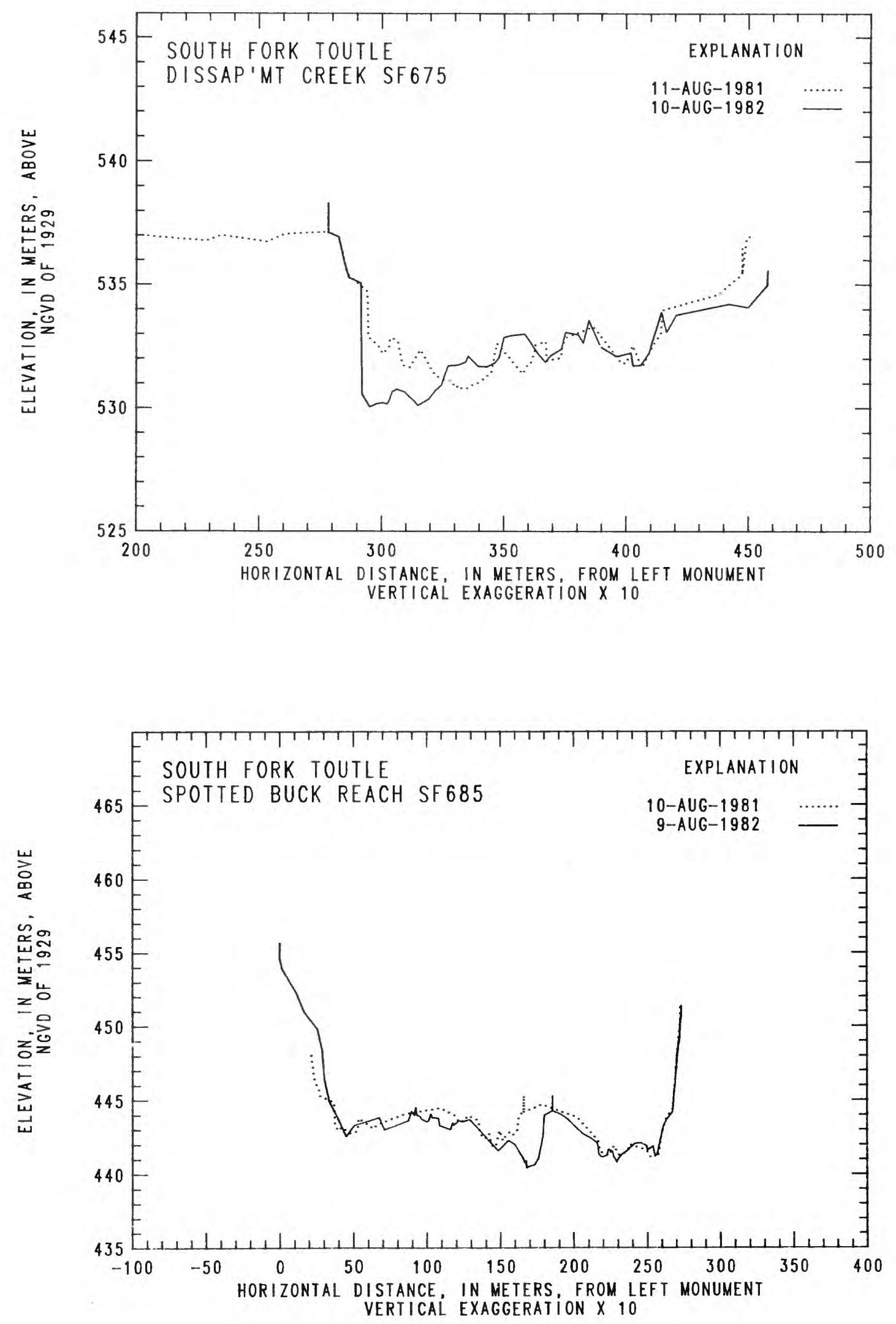

Figure 15.--Channel cross-section profiles for selected sites, South Fork Toutle River 

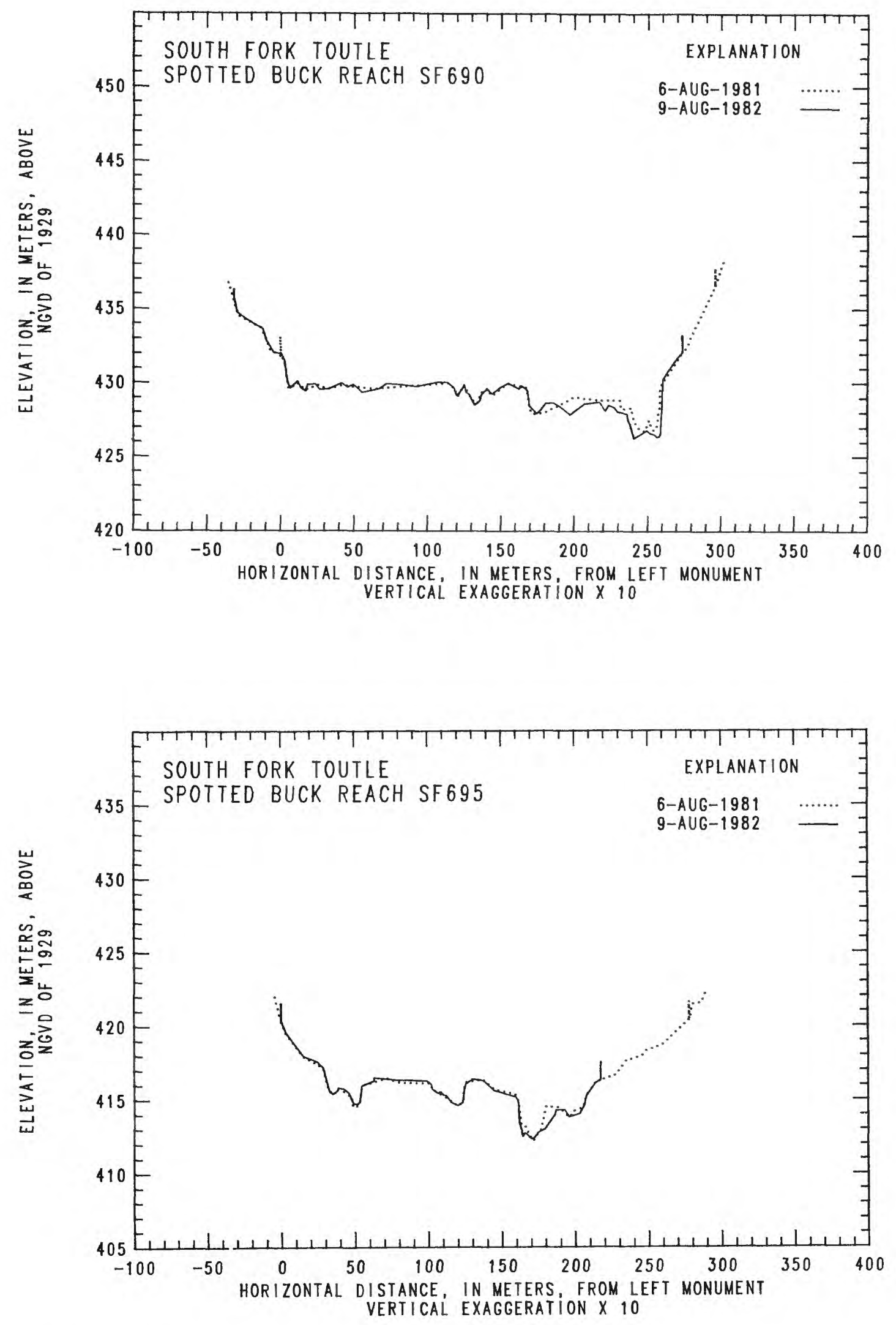

Figure 15.--Channel cross-section profiles for selected sites, South Fork Toutle River--Continued 

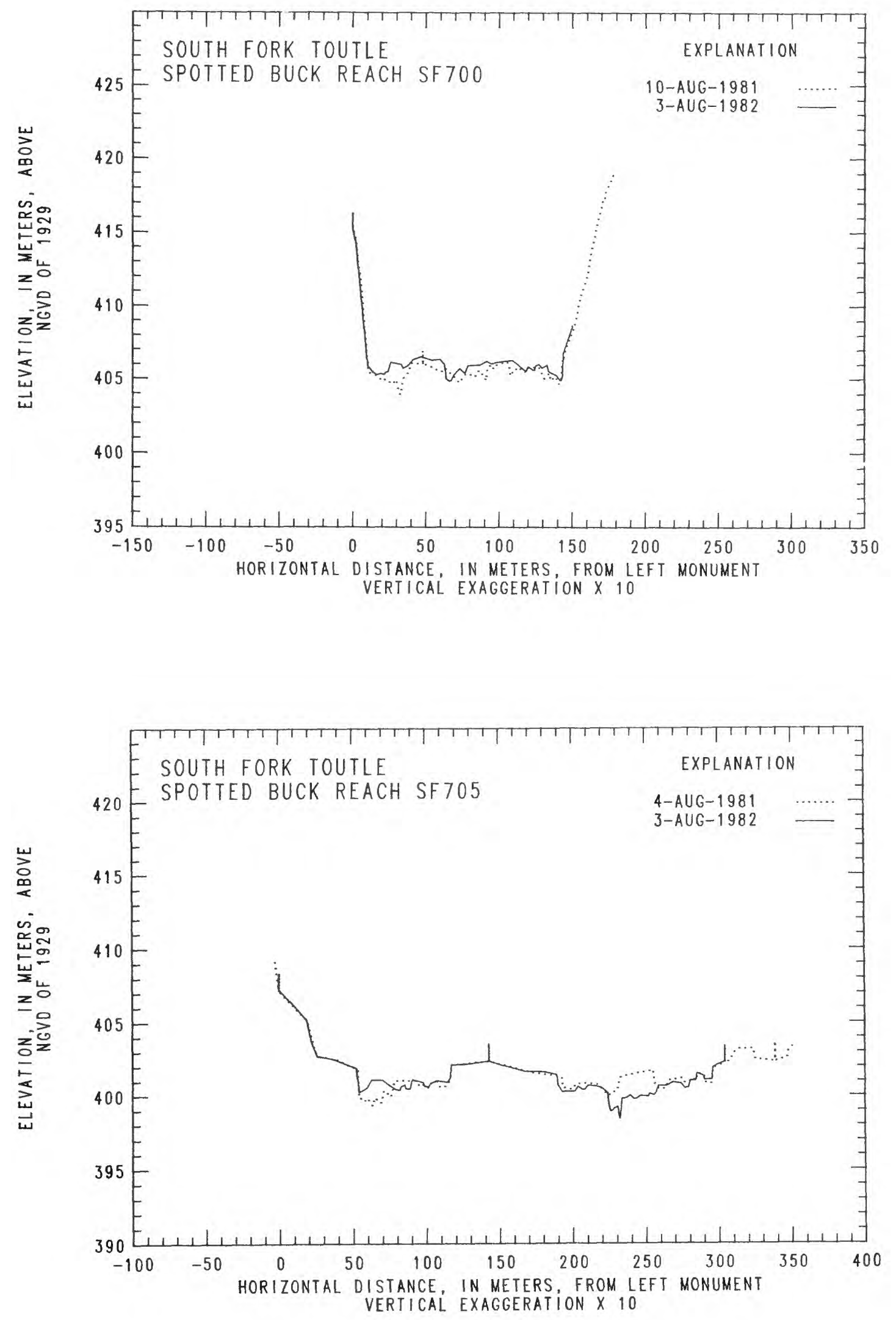

Figure 15.--Channel cross-section profiles for selected sites, South Fork Toutle River--Continued 

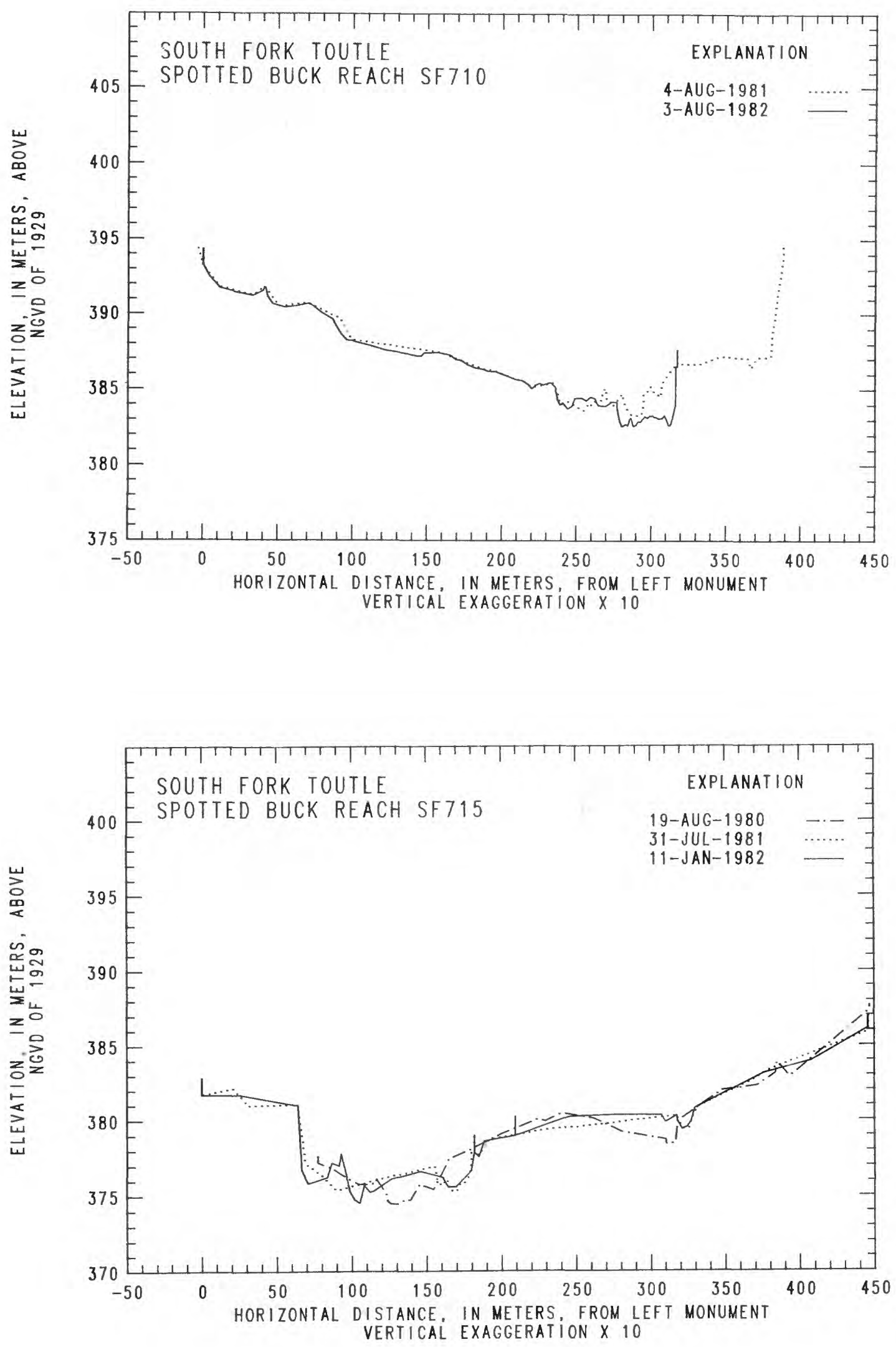

Figure 15.--Channel cross-section profiles for selected sites, South Fork Toutle River--Continued 

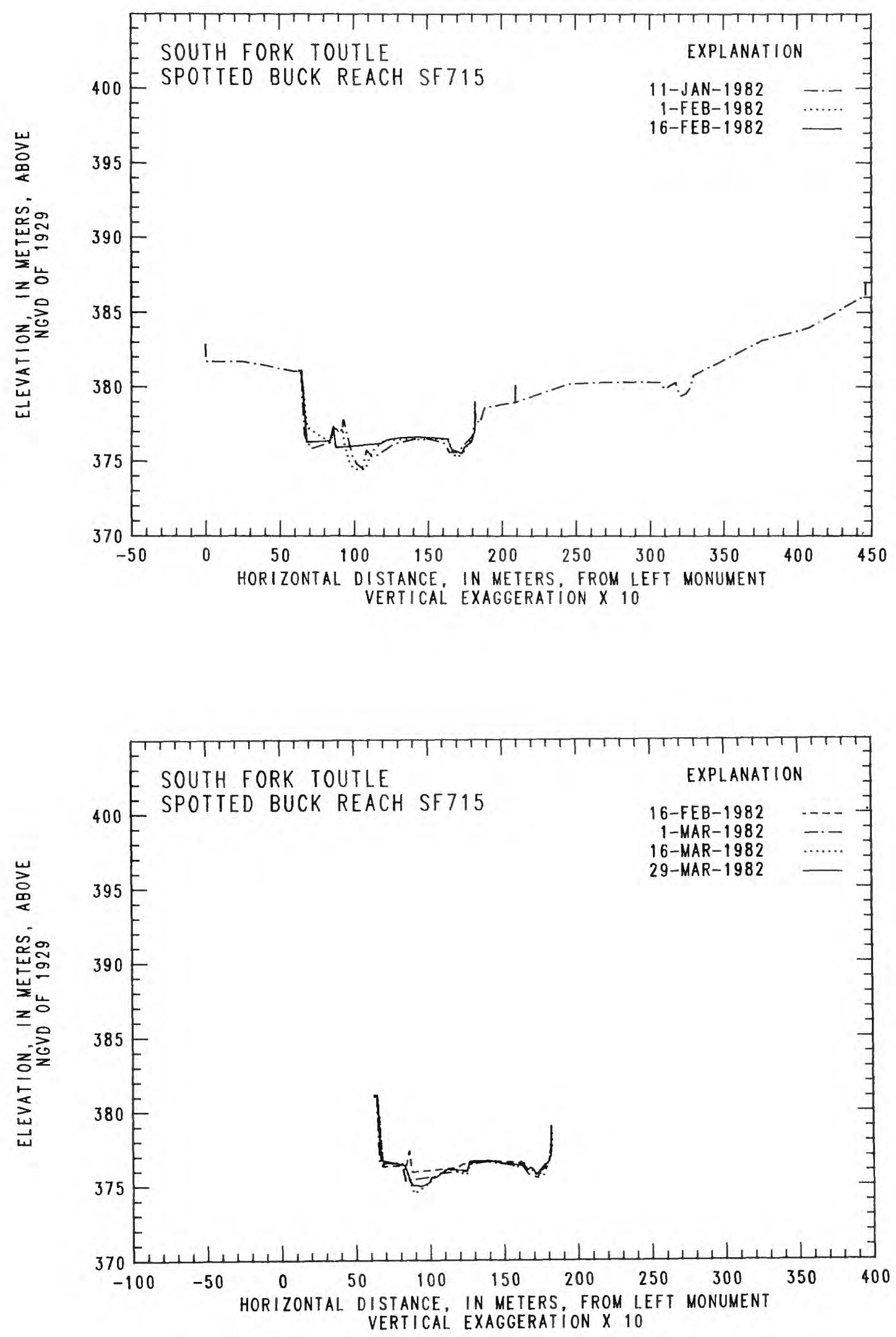

Figure 15.--Channel cross-section profiles for selected sites, South Fork Toutle River--Continued 

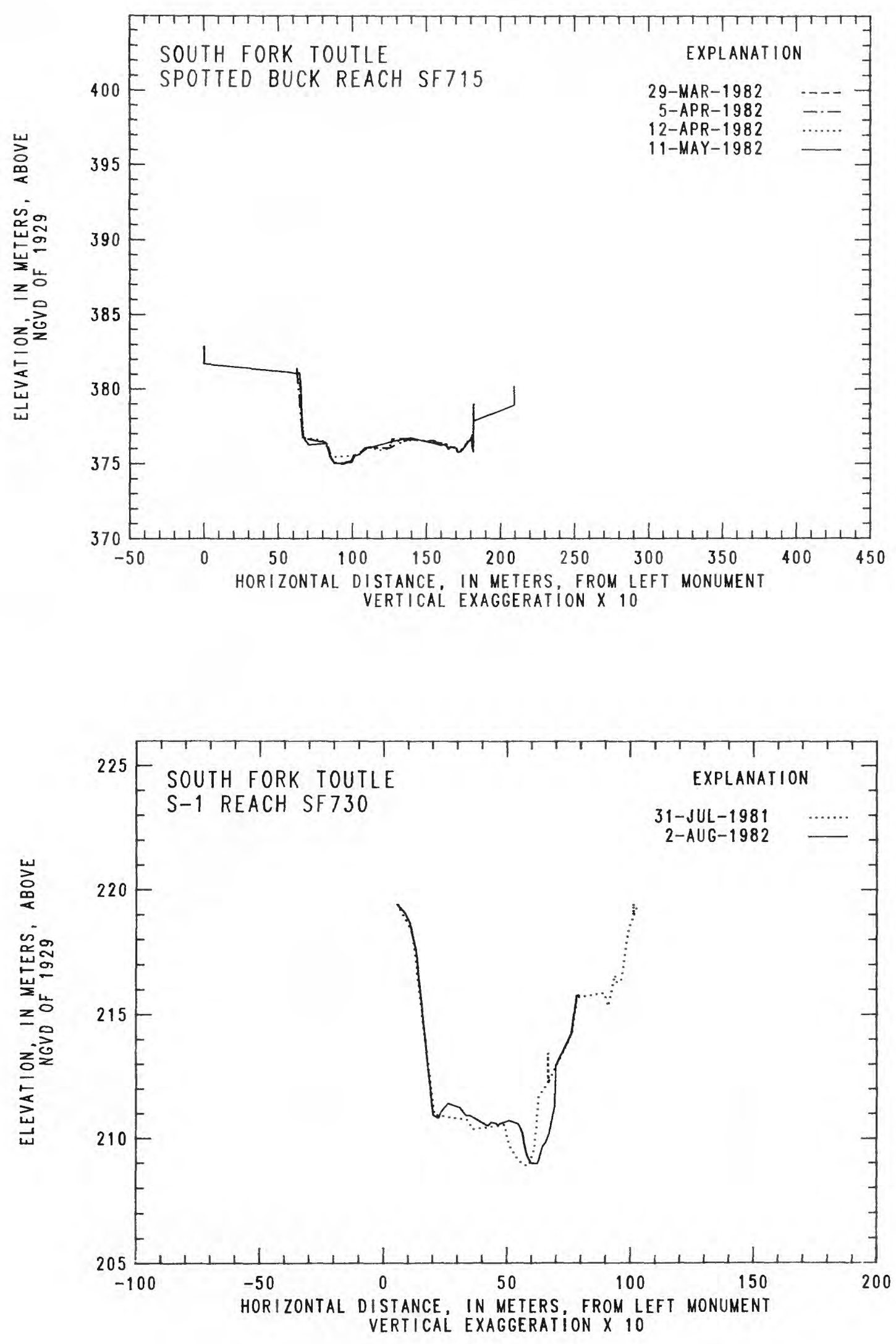

Figure 15.--Channel cross-section profiles for selected sites, South Fork Toutle River--Continued 

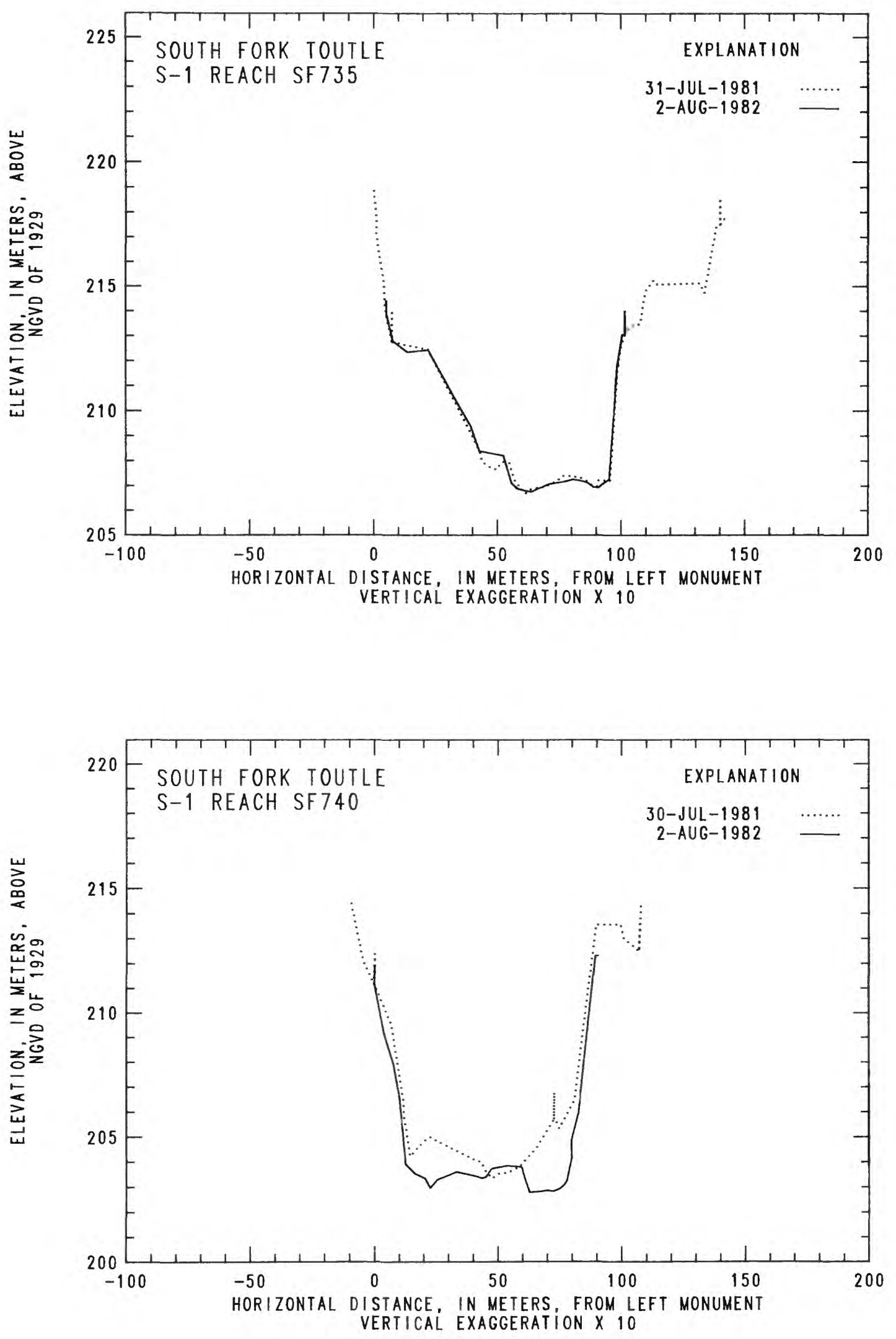

Figure 15.--Channel cross-section profiles for selected sites, South Fork Toutle River--Continued 

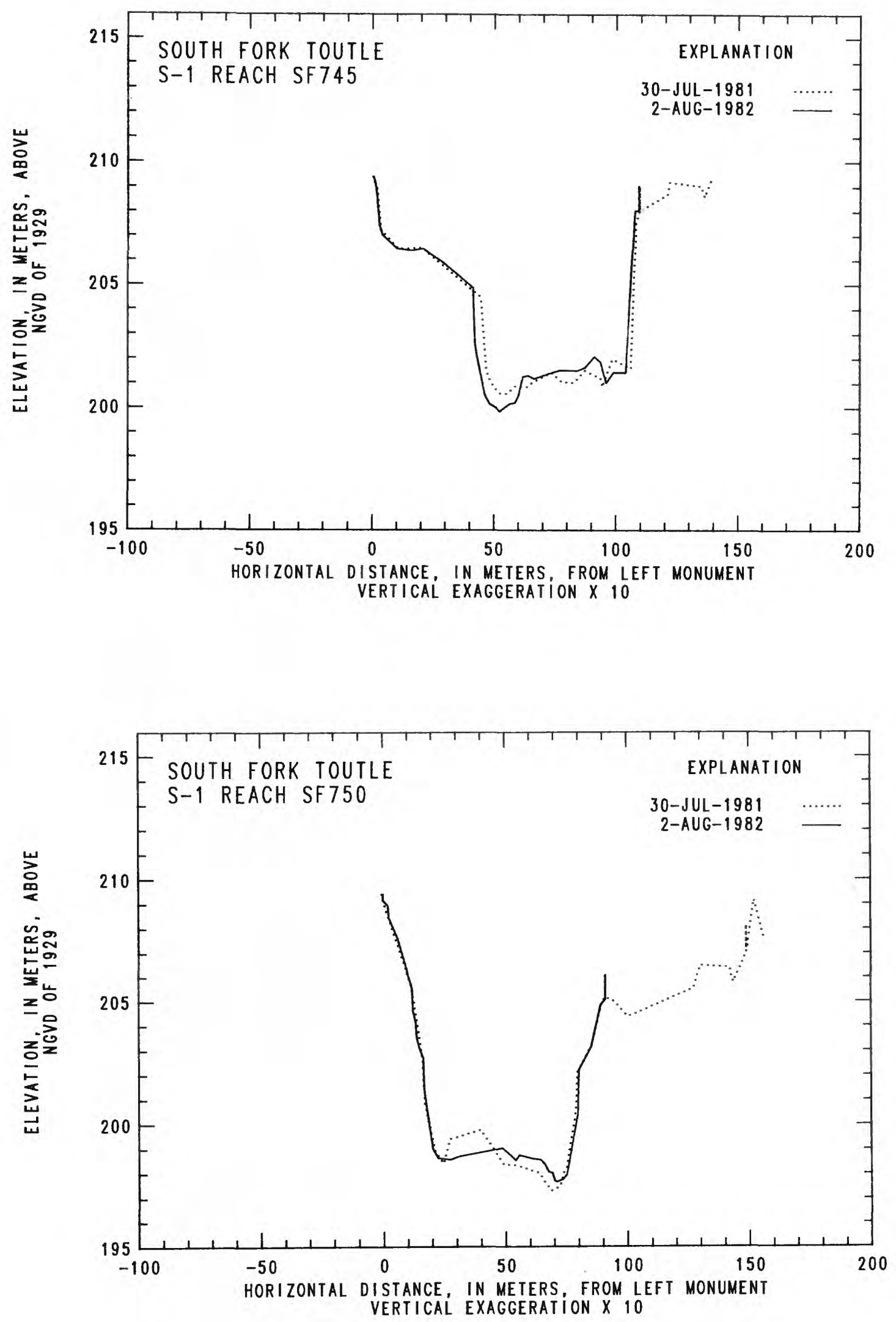

Figure 15.--Channel cross-section profiles for selected sites, South Fork Toutle River--Continued 

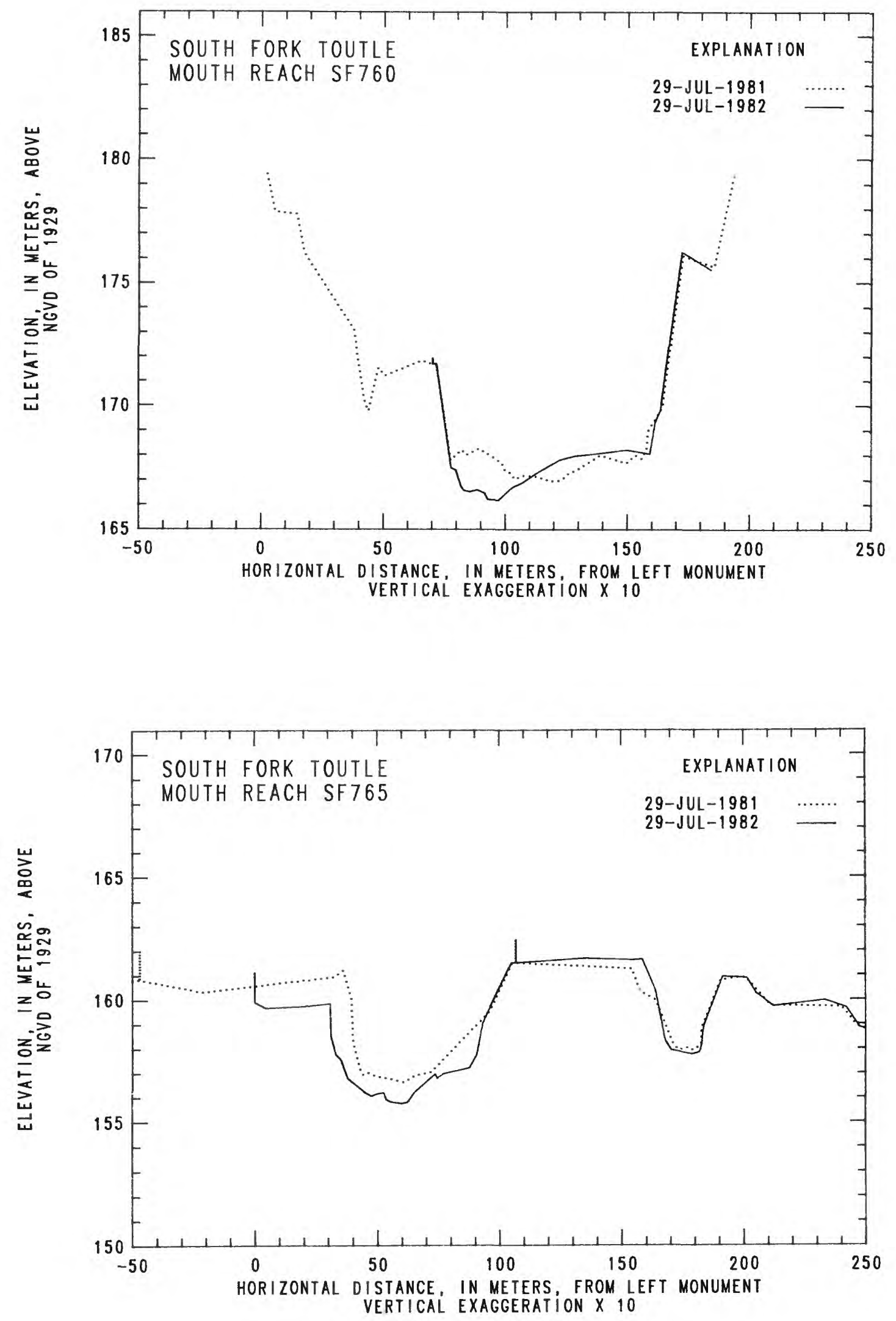

Figure 15.--Channel cross-section profiles for selected sites, South Fork Toutle River--Continued 
Study basins within the Toutle River system (fig. 1) were selected to monitor channel response to a wide spectrum of volcanic effects of the May 18, 1980, and subsequent eruptions. The Toutle River system drains an area of $1,322 \mathrm{~km}^{2}$, including the north and east flanks of Mount St. Helens. The three major tributaries, the Green, North Fork Toutle, and South Fork Toutle Rivers, occupy subparallel basins trending to the west. The variability in channel gradient, drainage basin size, and volcanic impact between and within the main subbasins is summarized in table 1 and figures 2 through 6 .

\section{Green River}

Green River occupies an east-west valley north of and subparallel to the North Fork Toutle River valley (fig. 1). The draina'ge basin heads in rugged metavolcanic terrain northeast of Spirit Lake.

Half of the Green River drainage was significantly altered by the blast (table 1). Severe timber blowdown and tephra deposition occurred in much of the affected area. Air-fall ejecta from the May 18, 1980, eruption was deposited to thicknesses greater than $0.50 \mathrm{~m}$ in the headwaters of the Shultz Creek drainage (fig. 1). The northwest end of the basin received no tephra from the May 18, 1980, eruption and on1y a veneer of ash on May 25, 1980 (Waitt and Dzurisin, 1981; Waitt and others, 1981). Additional unconsolidated sediment was produced when the flow of the Green River was ponded behind the North Fork Toutle lahar about $2.5 \mathrm{~km}$ upstream from the mouth. As much as $2 \mathrm{~m}$ of sand and silt was deposited in and near the channel along this reach.

A gaging station was re-established in September $1980,3.2 \mathrm{~km}$ upstream from the mouth. Water and suspended-sediment discharge data have been collected since. Seventeen cross sections were installed in the summer of 1980 to monitor changes in channel geometry. These cross sections are grouped into four clusters (table 3 and figures 2, 3, 4, 10, and 11). Cross sections along the Green River are surveyed annually.

\section{North Fork Toutle River}

Prior to the May 18th eruption, the source of the North Fork Toutle River was Spirit Lake, which collected runoff from $46 \mathrm{~km}^{2}$ of rugged terrain and uncut timber lands north of Mount St. Helens. Currently, the headwaters of the North Fork Toutle River are in the crater of Mount St. Helens. The upper $24 \mathrm{~km}$ of the North Fork Toutle valley contains the 2.8- $\mathrm{km}^{3}$ debris-avalanche deposit, emplaced during the May 18, 1980, eruption. The deposit covers $60 \mathrm{~km}^{2}$, with an average thickness of 45 $\mathrm{m}$. Maximum thickness of the debris- avalanche deposit is $195 \mathrm{~m}$ in an area $3 \mathrm{~km}$ west of Spirit Lake. Evolution of a through-flowing drainage network on the hummocky avalanche deposit has increased contributing drainage area above the toe of the deposit from $80 \mathrm{~km}^{2}$ on May 19, 1980, to about $282 \mathrm{~km}^{2}$ in 1983 (fig. 7). 

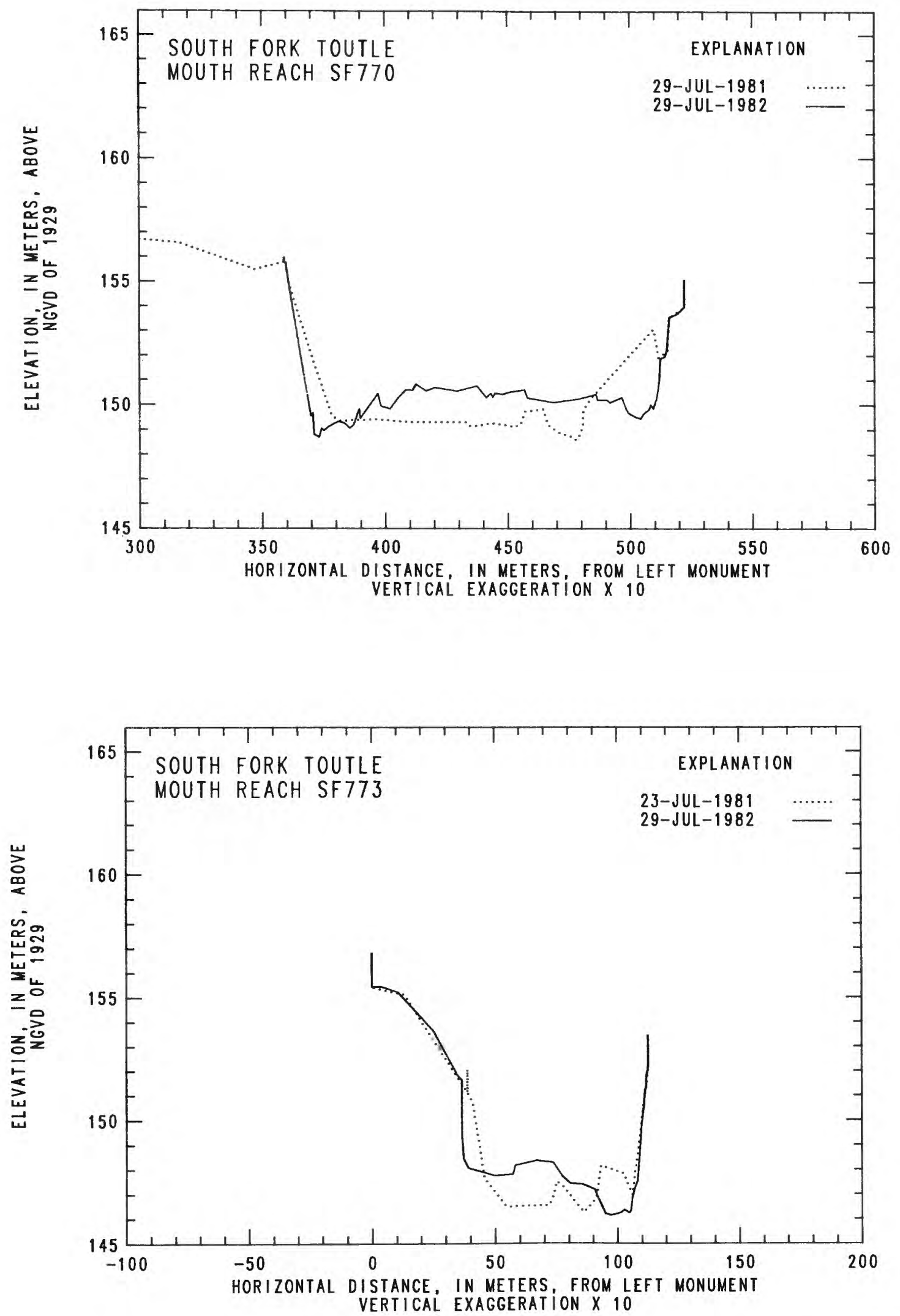

Figure 15.--Channel cross-section profiles for selected sites, South Fork Toutle River--Continued 

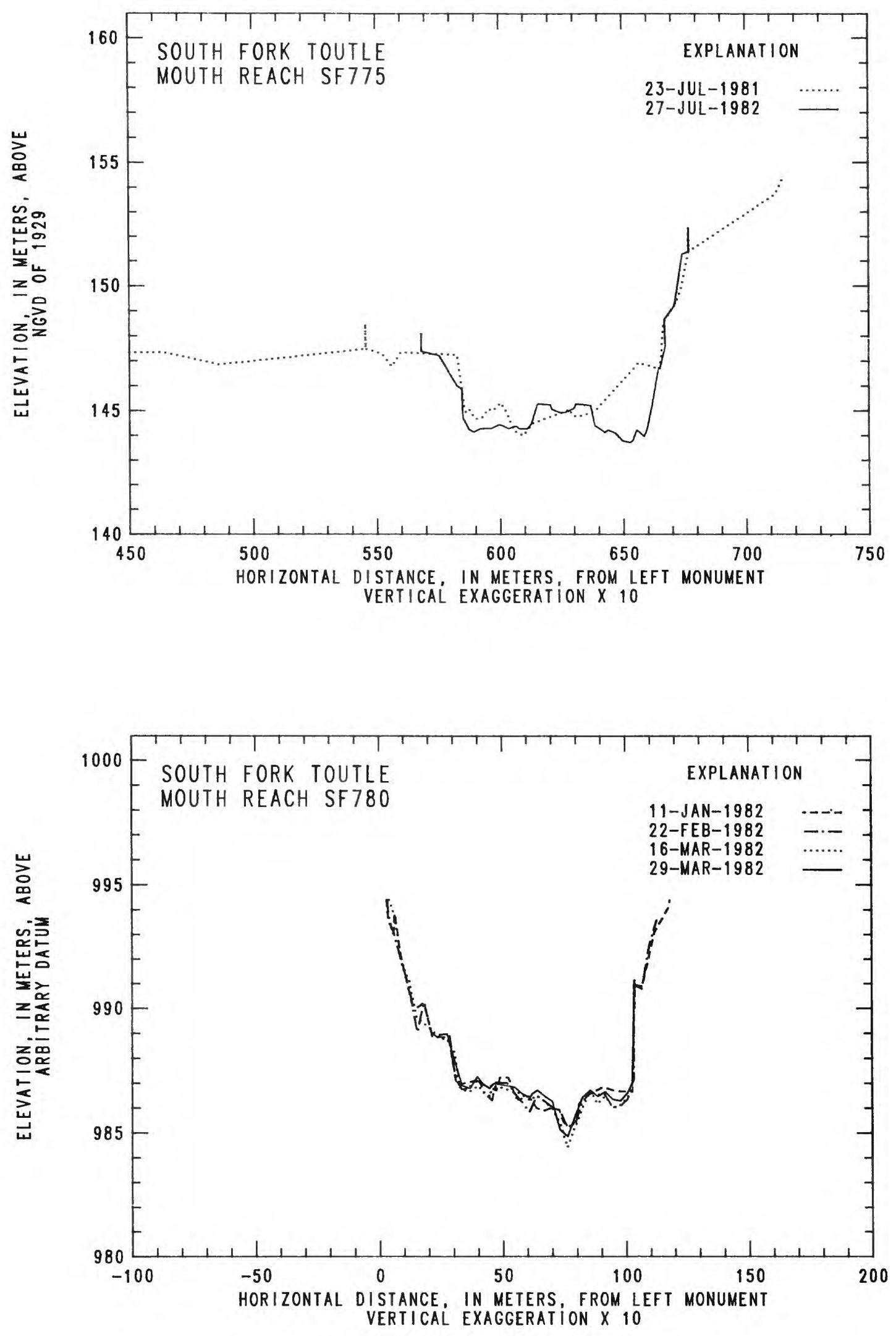

Figure 15.--Channel cross-section profiles for selected sites, South Fork Toutle River--Continued 

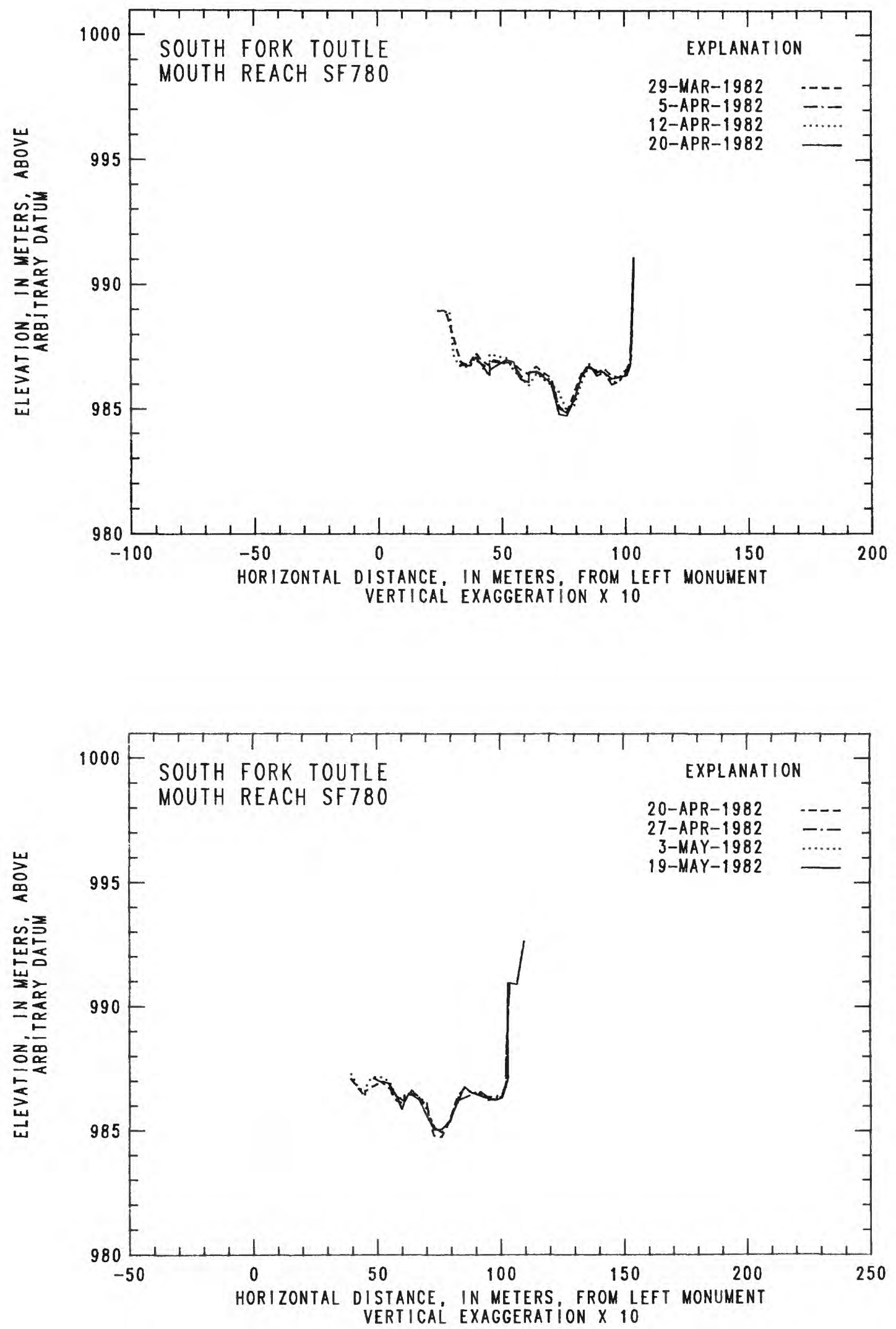

Figure 15.--Channe1 cross-section profiles for selected sites, South Fork Toutle River--Continued 

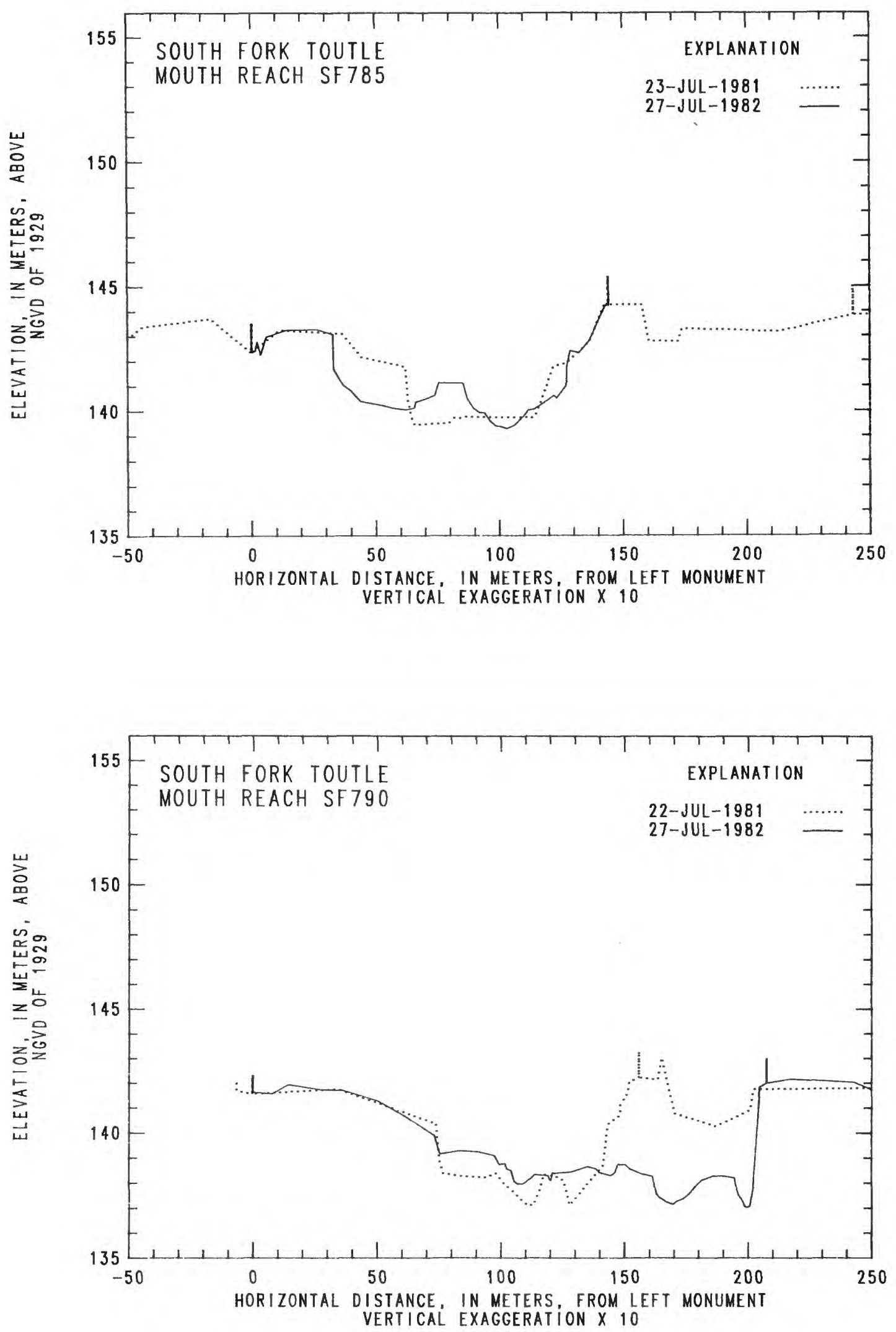

Figure 15.--Channel cross-section profiles for selected sites, South Fork Toutle River--Continued 

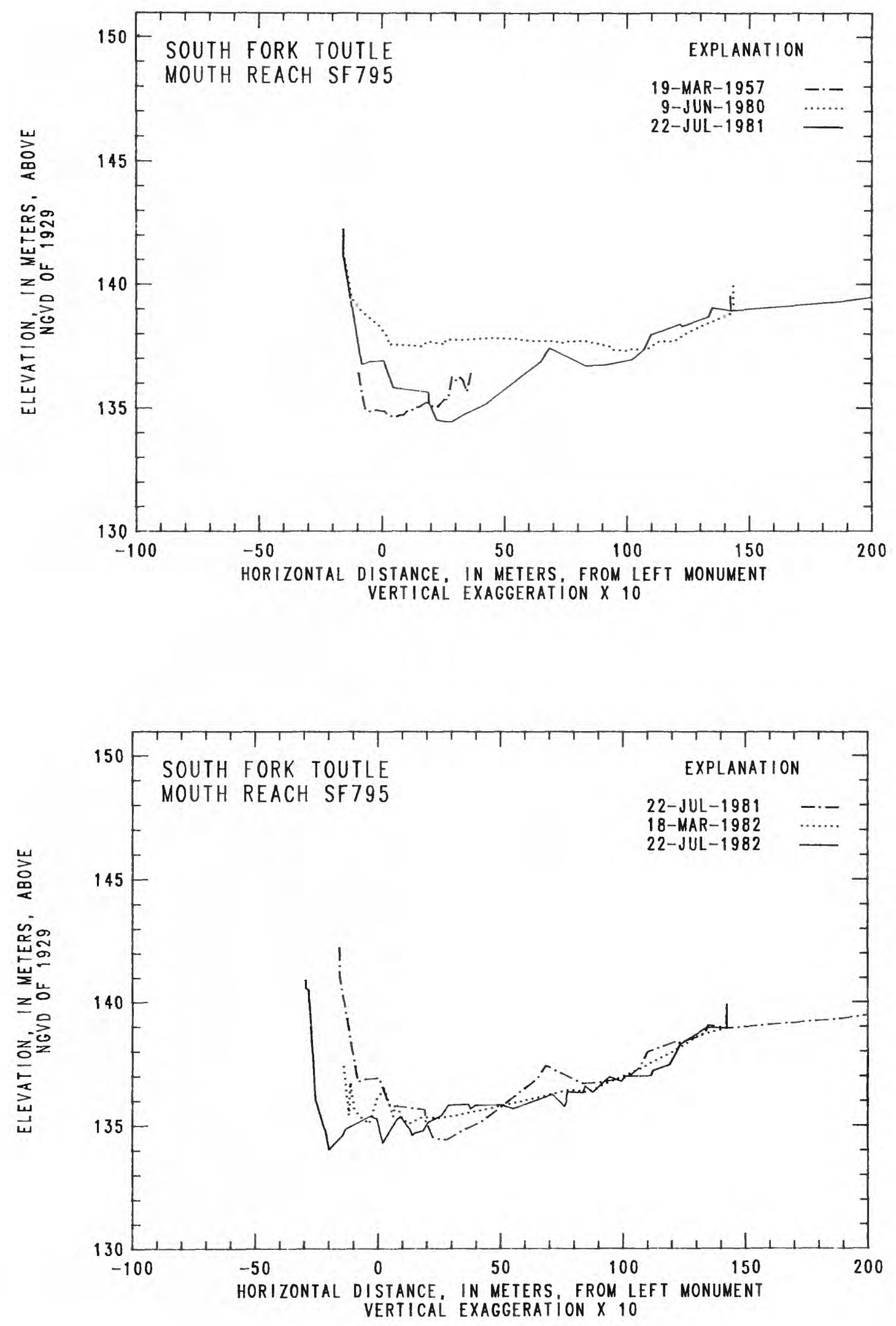

Figure 15.--Channel cross-section profiles for selected sites, South Fork Toutle River--Continued 

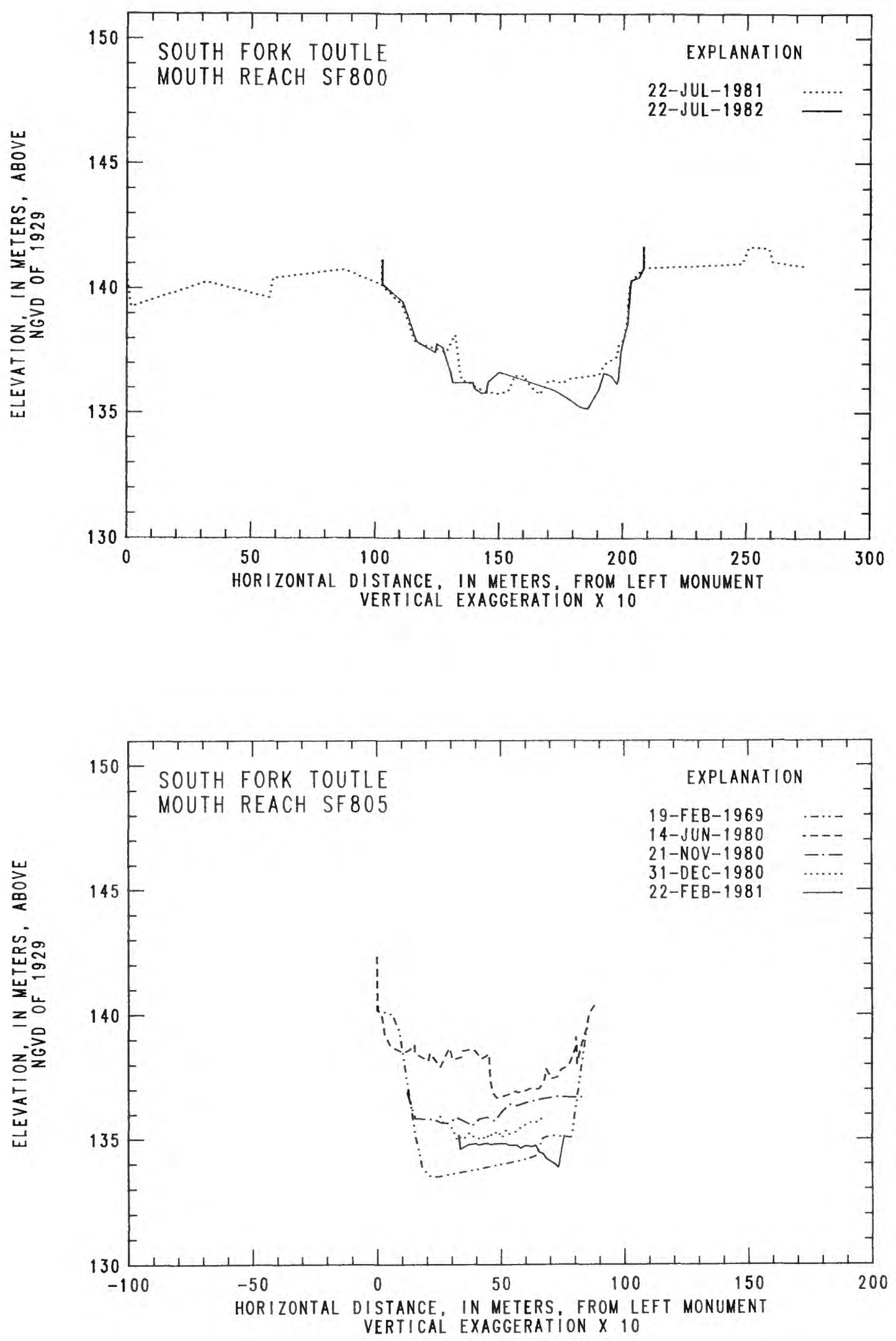

Figure 15.--Channel cross-section profiles for selected sites, South Fork Toutle River--Continued 

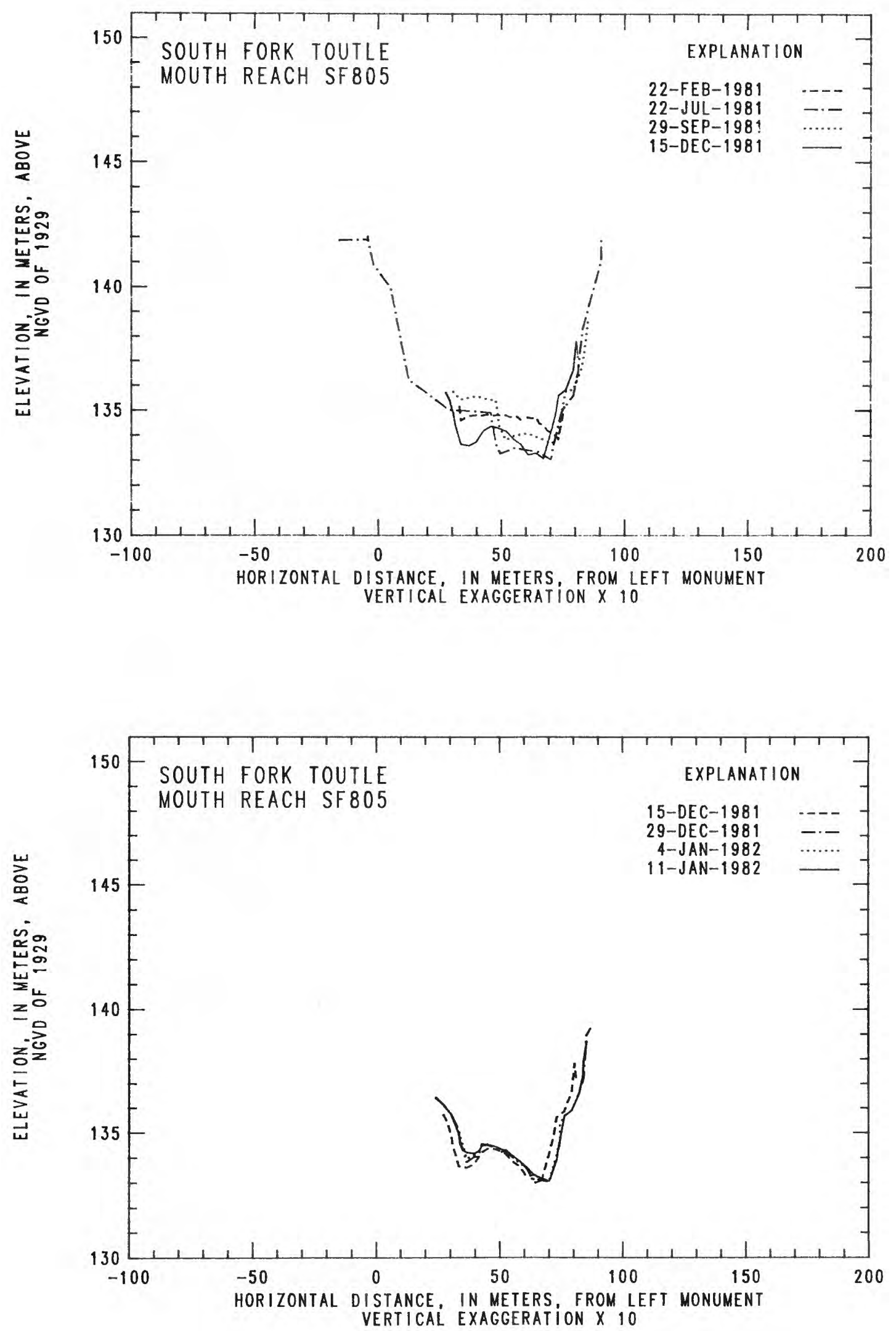

Figure 15.--Channel cross-section profiles for selected sites, South Fork Toutle River--Continued 

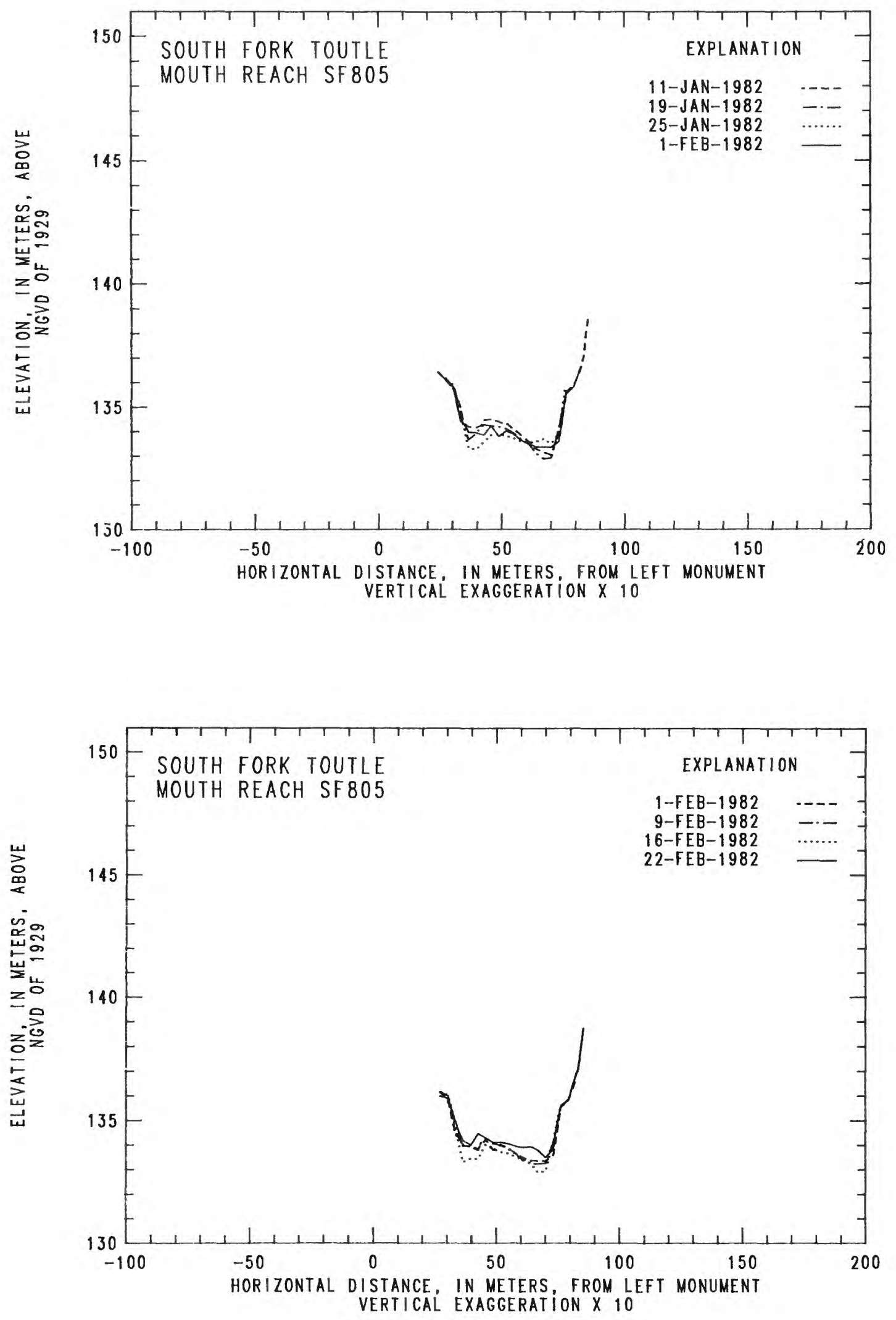

Figure 15.--Channel cross-section profiles for selected sites, South Fork Toutle River--Continued 

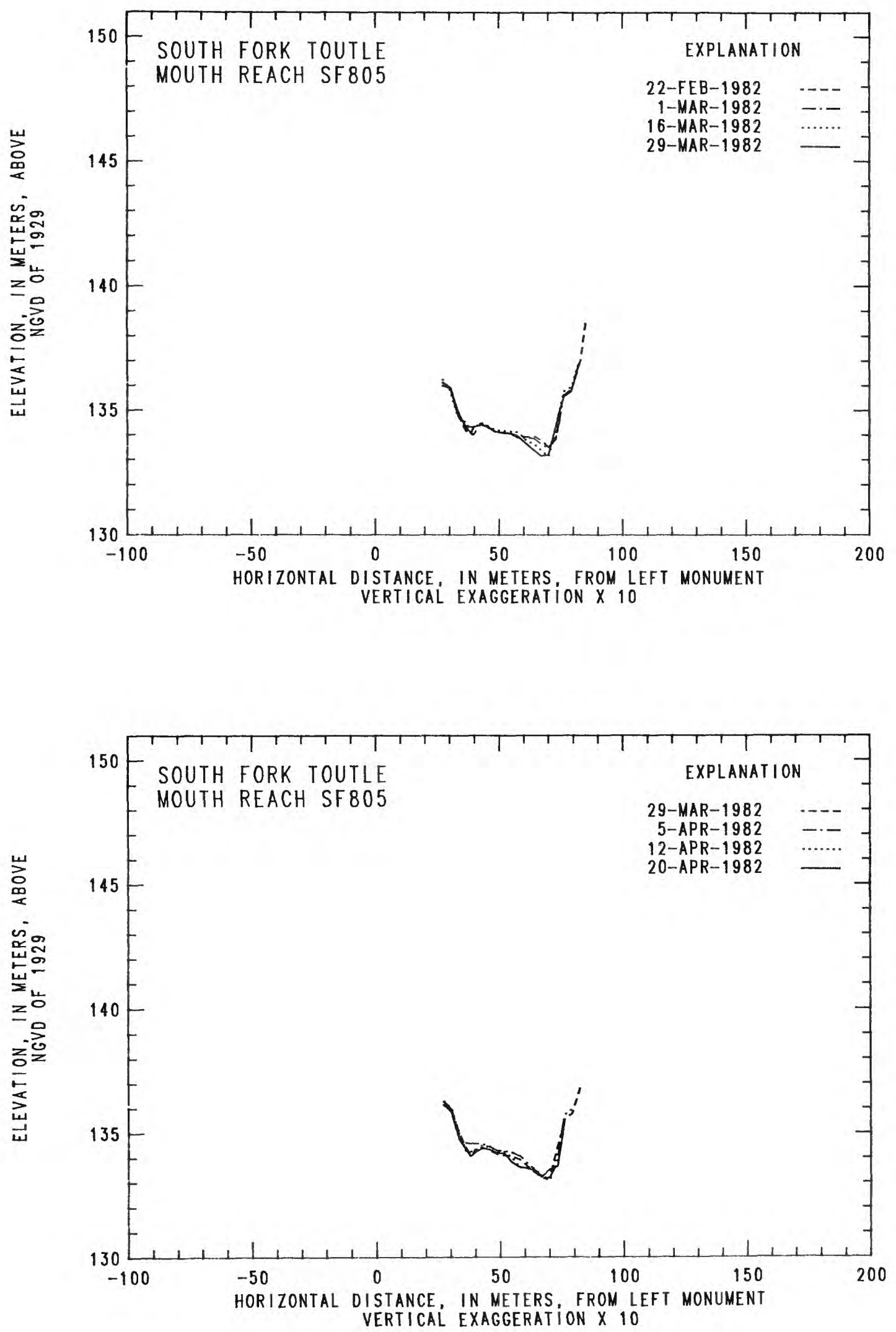

Figure 15.--Channel cross-section profiles for selected sites, South Fork Toutle River--Continued 

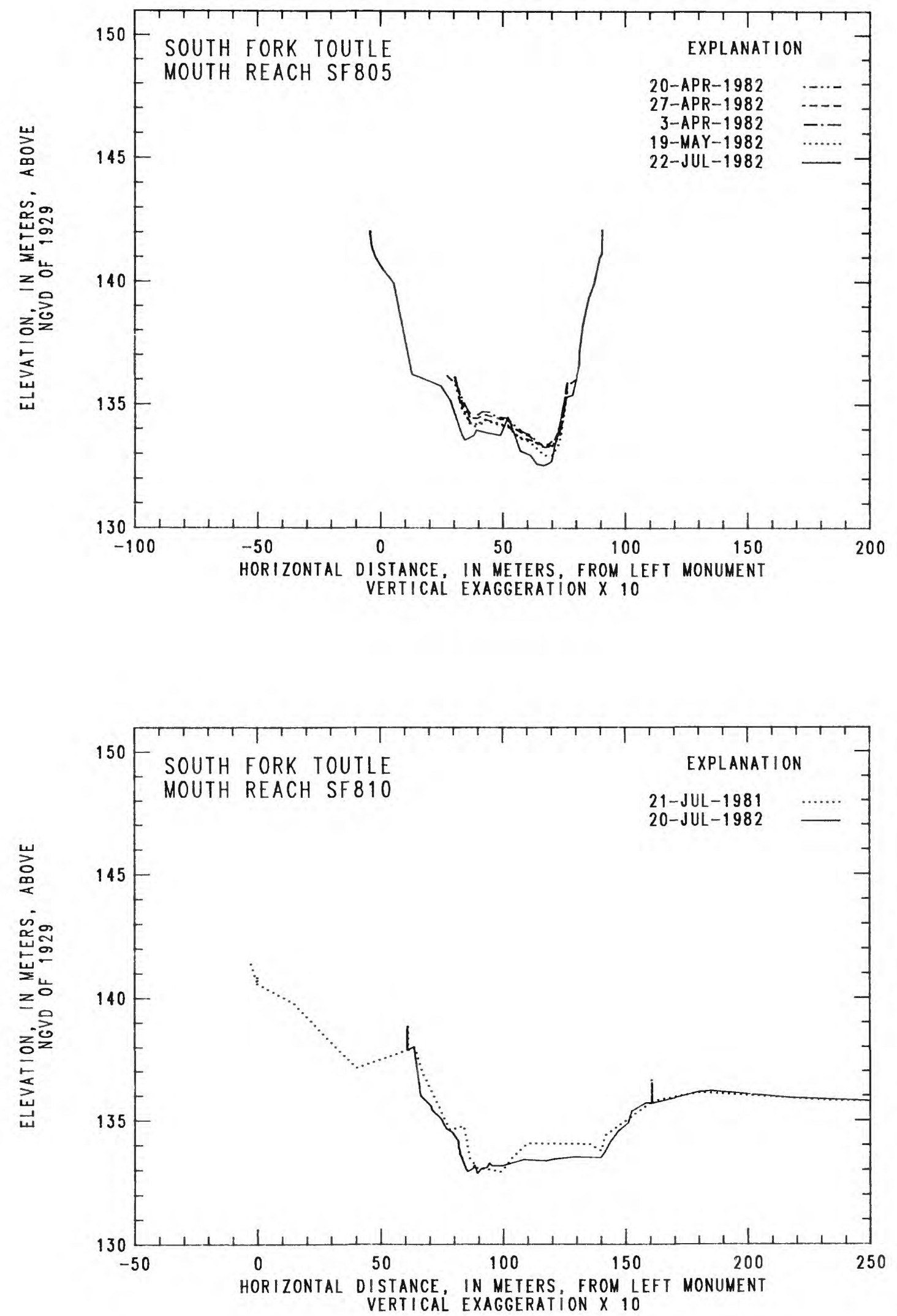

Figure 15.--Channel cross-section profiles for selected sites, South Fork Toutle River--Continued 


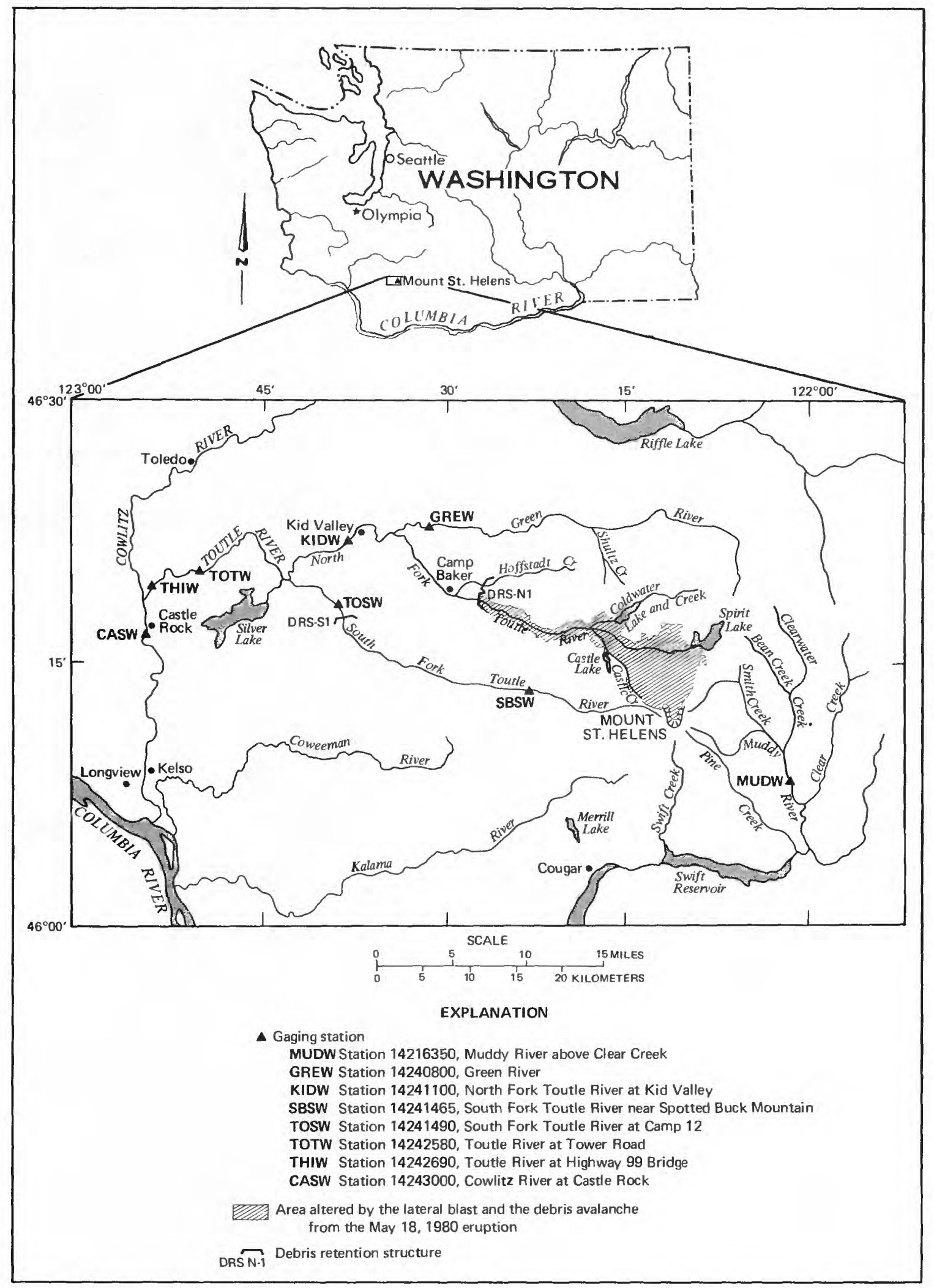

Figure 1.--Location of Toutle River drainage, Mount St. Helens, lateral blast-affected area, and debris-avalanche deposit. 


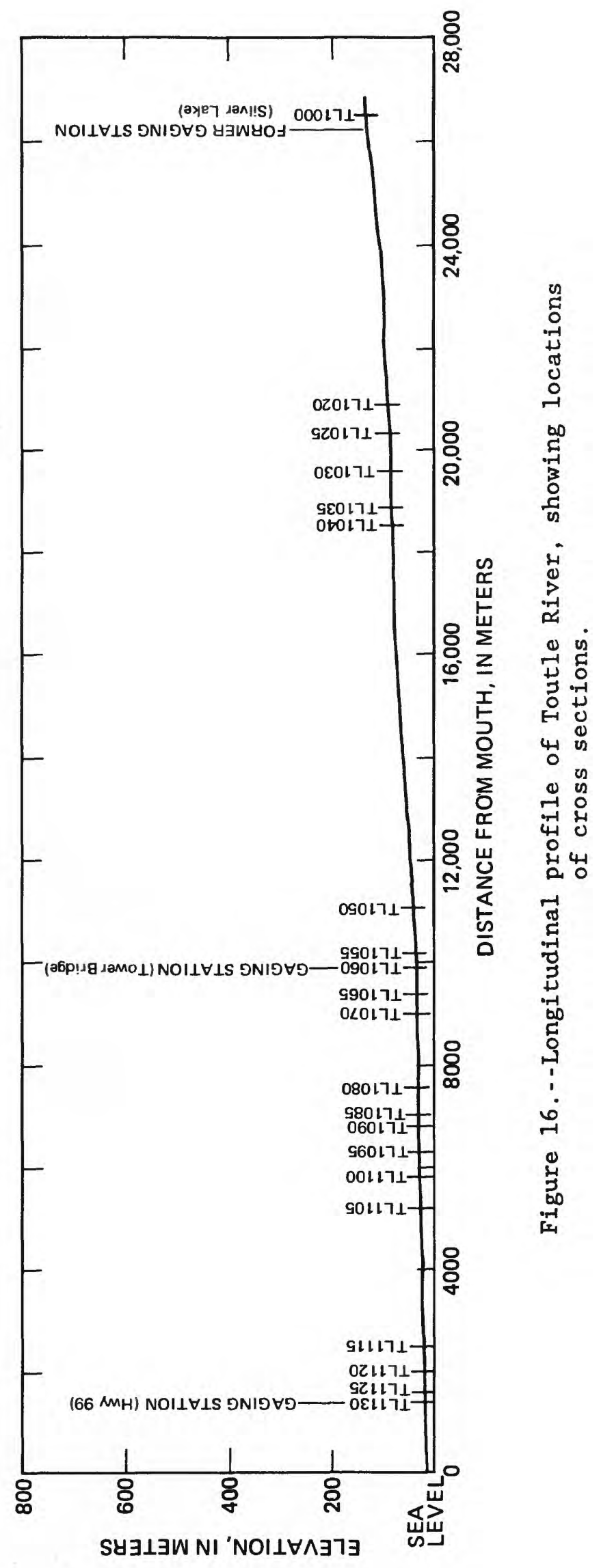



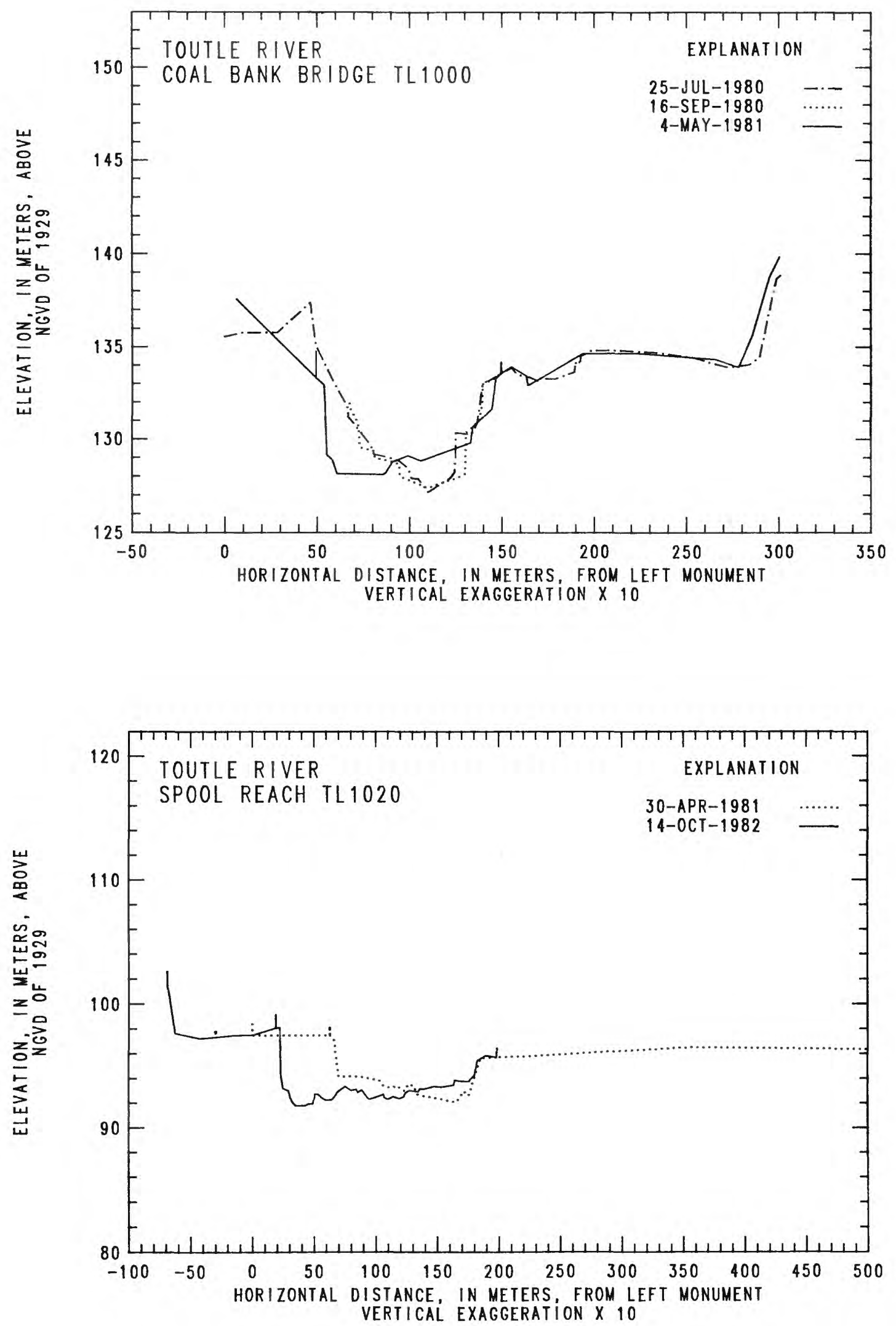

Figure 17.--Channel cross-section profiles for selected sites, Toutle River 

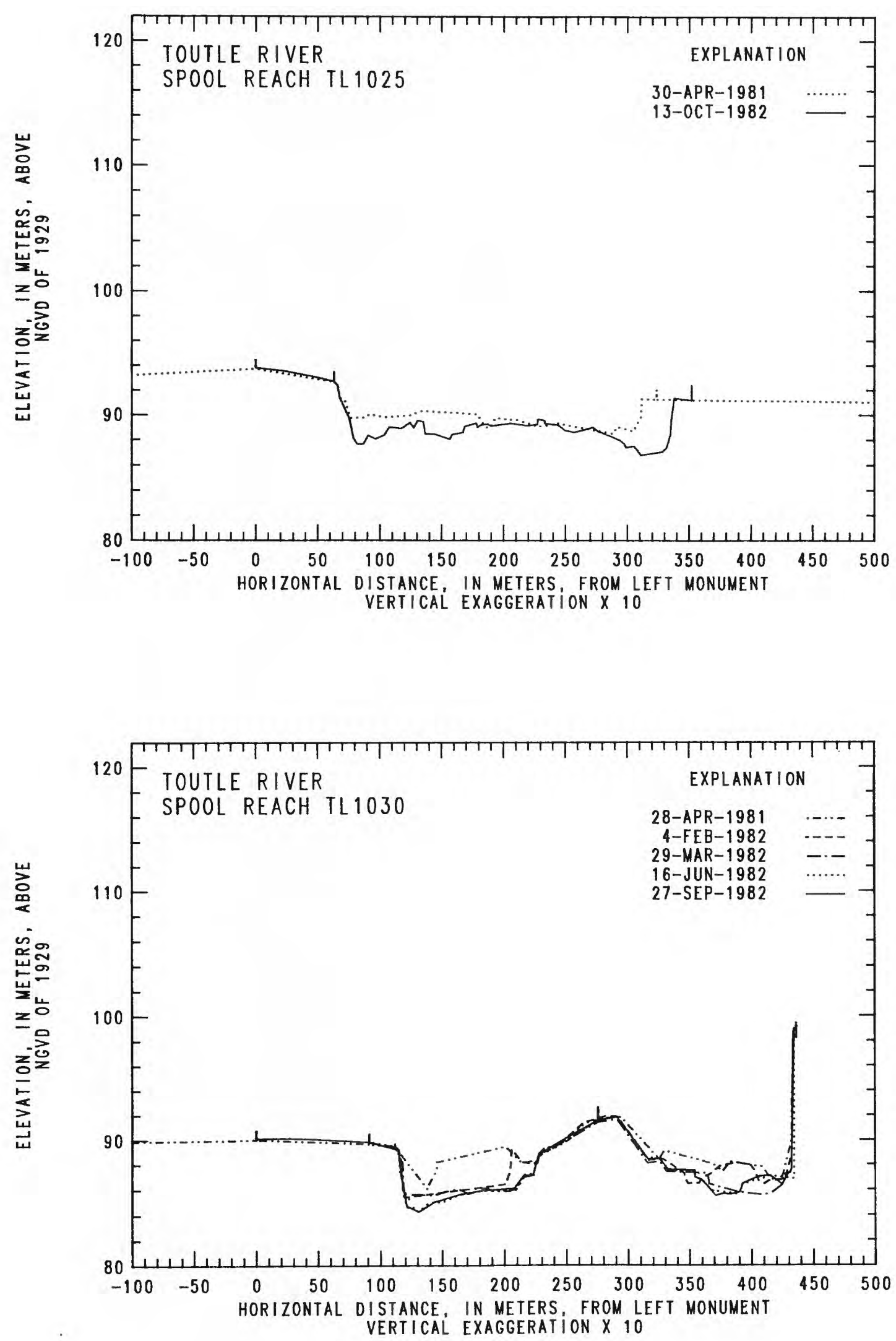

Figure 17.--Channel cross-section profiles for selected sites, Toutle River--Continued 

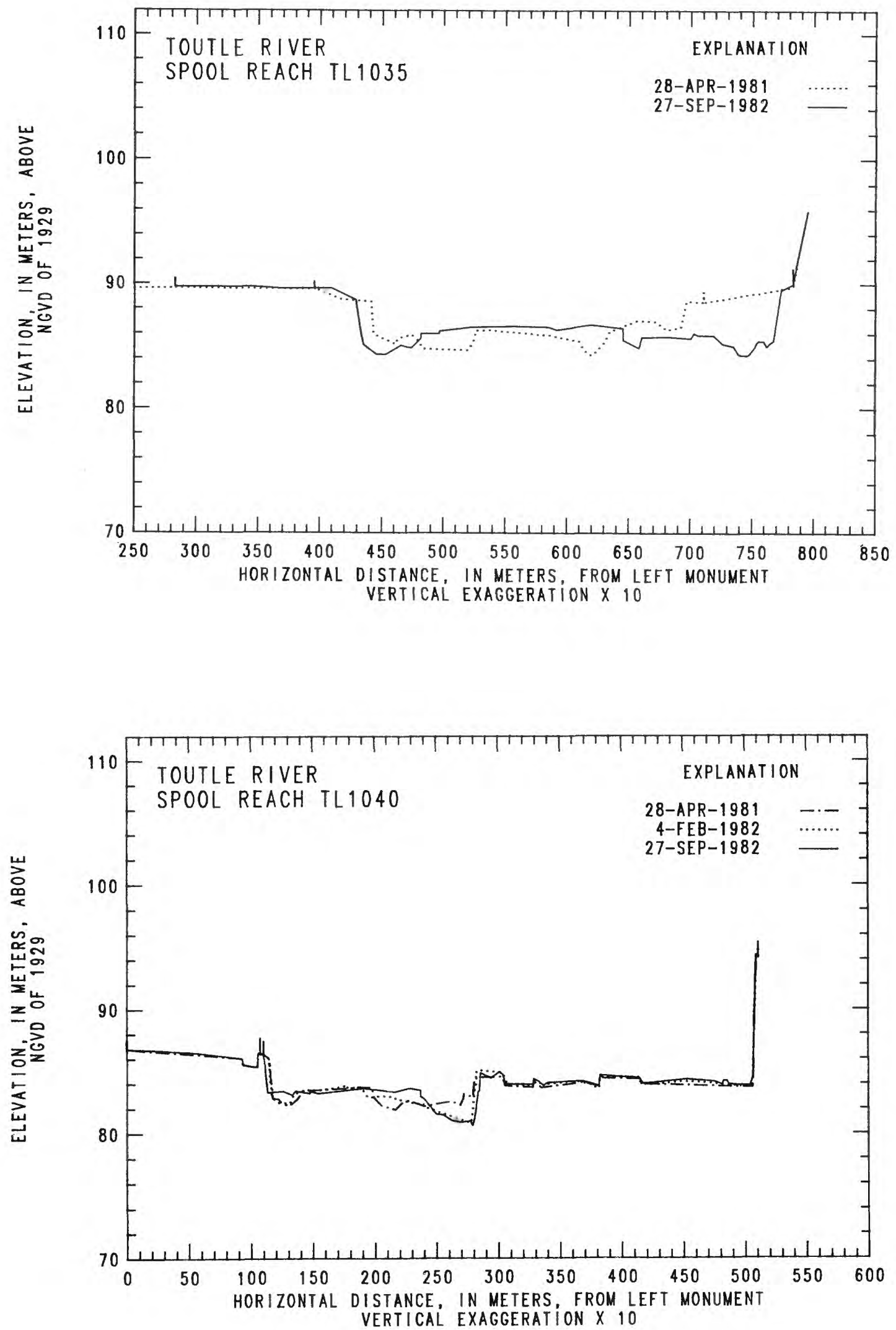

Figure 17.--Channel cross-section profiles for selected sites, Toutle River--Continued 

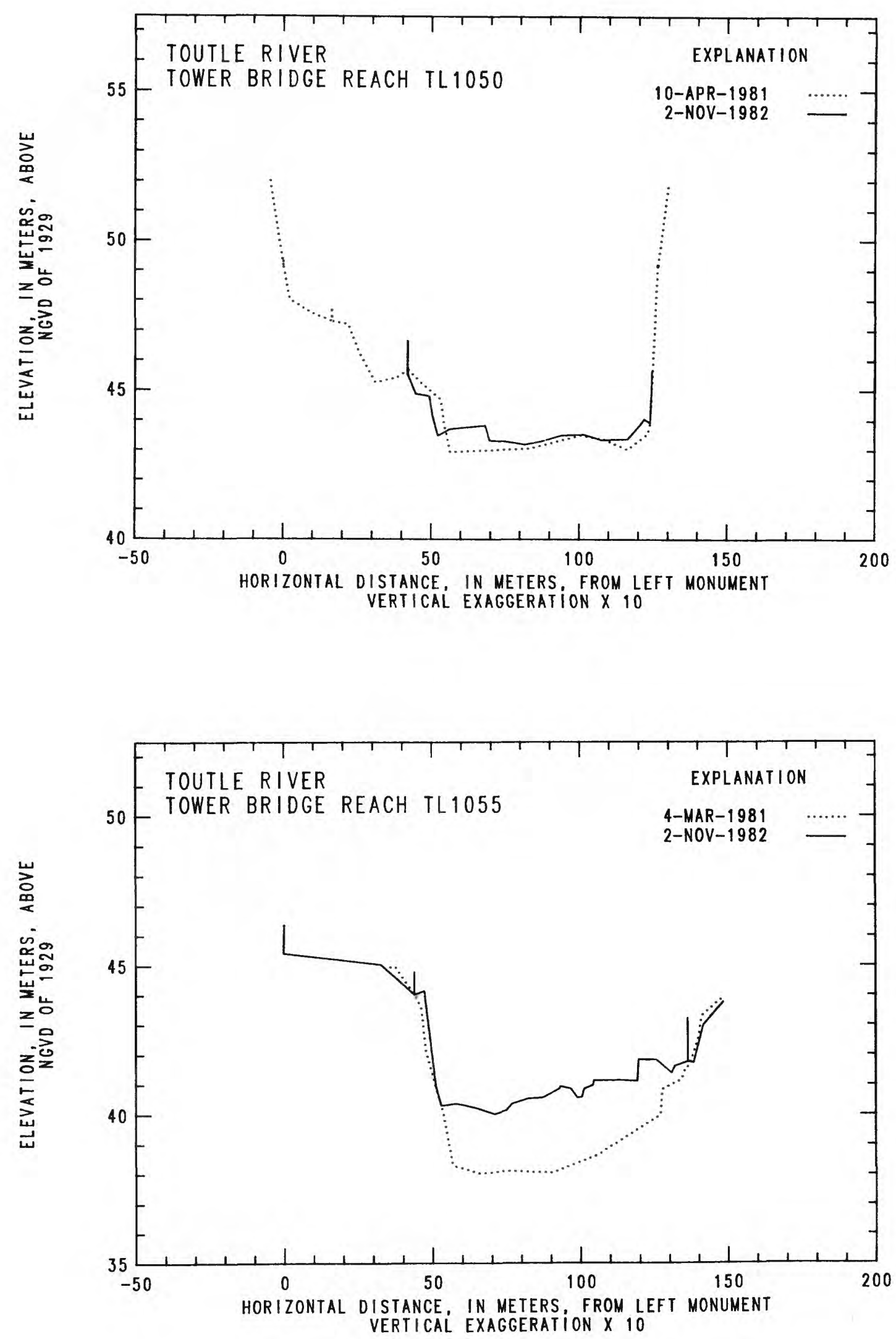

Figure 17.--Channel cross-section profiles for selected sites, Toutle River--Continued 

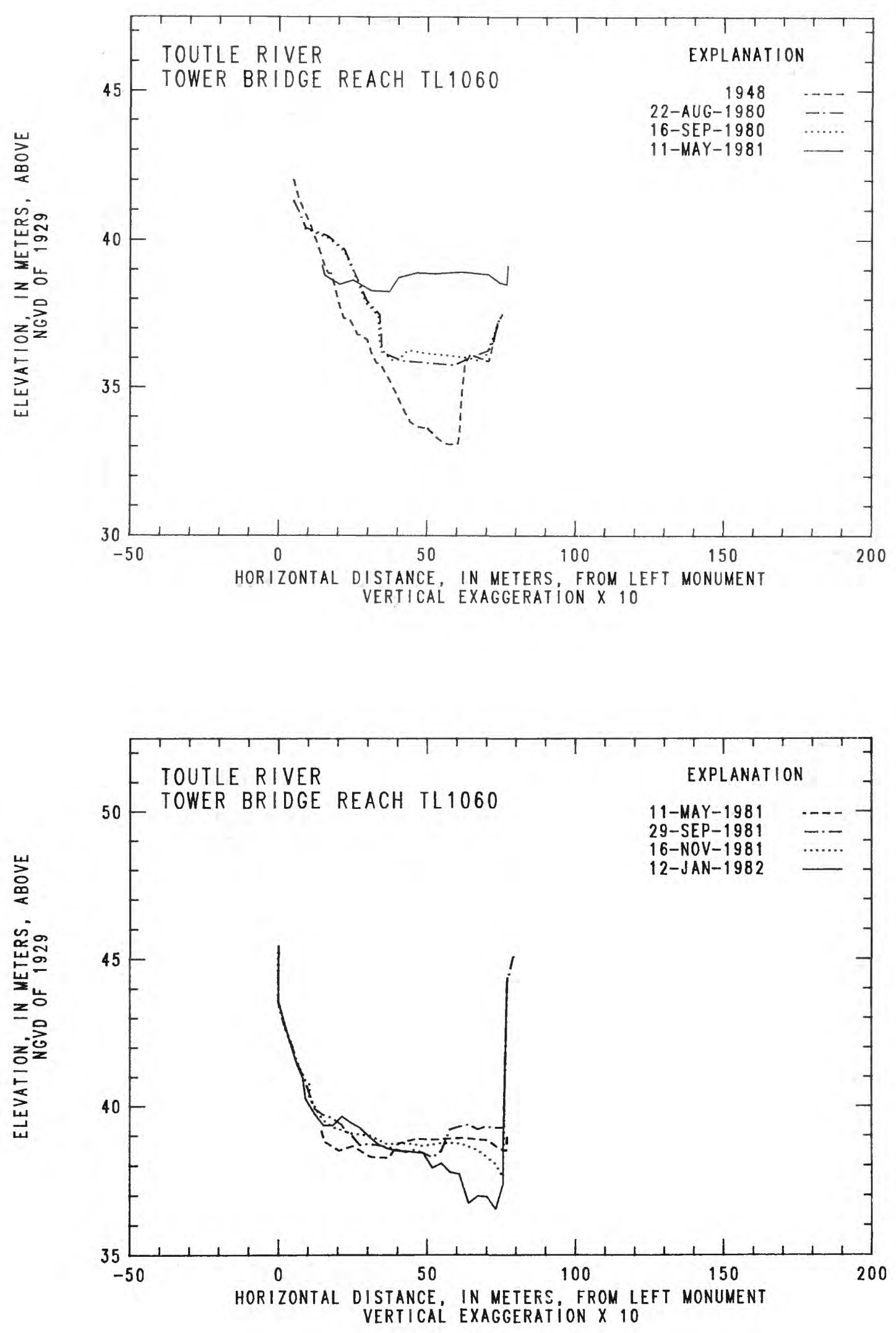

Figure 17.--Channel cross-section profiles for selected sites, Toutle River--Continued 

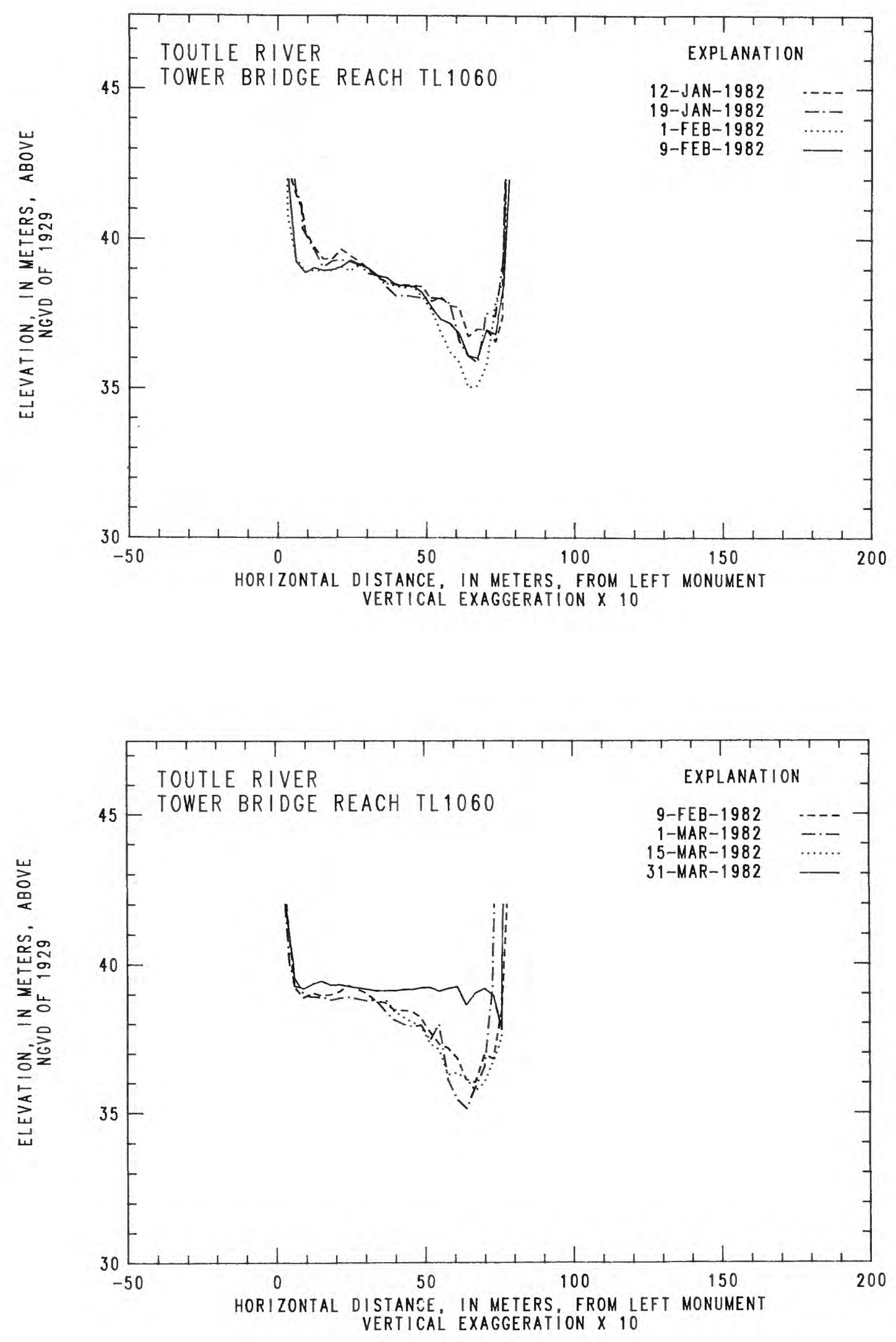

Figure 17.--Channel cross-section profiles for selected sites, Toutle River--Continued 

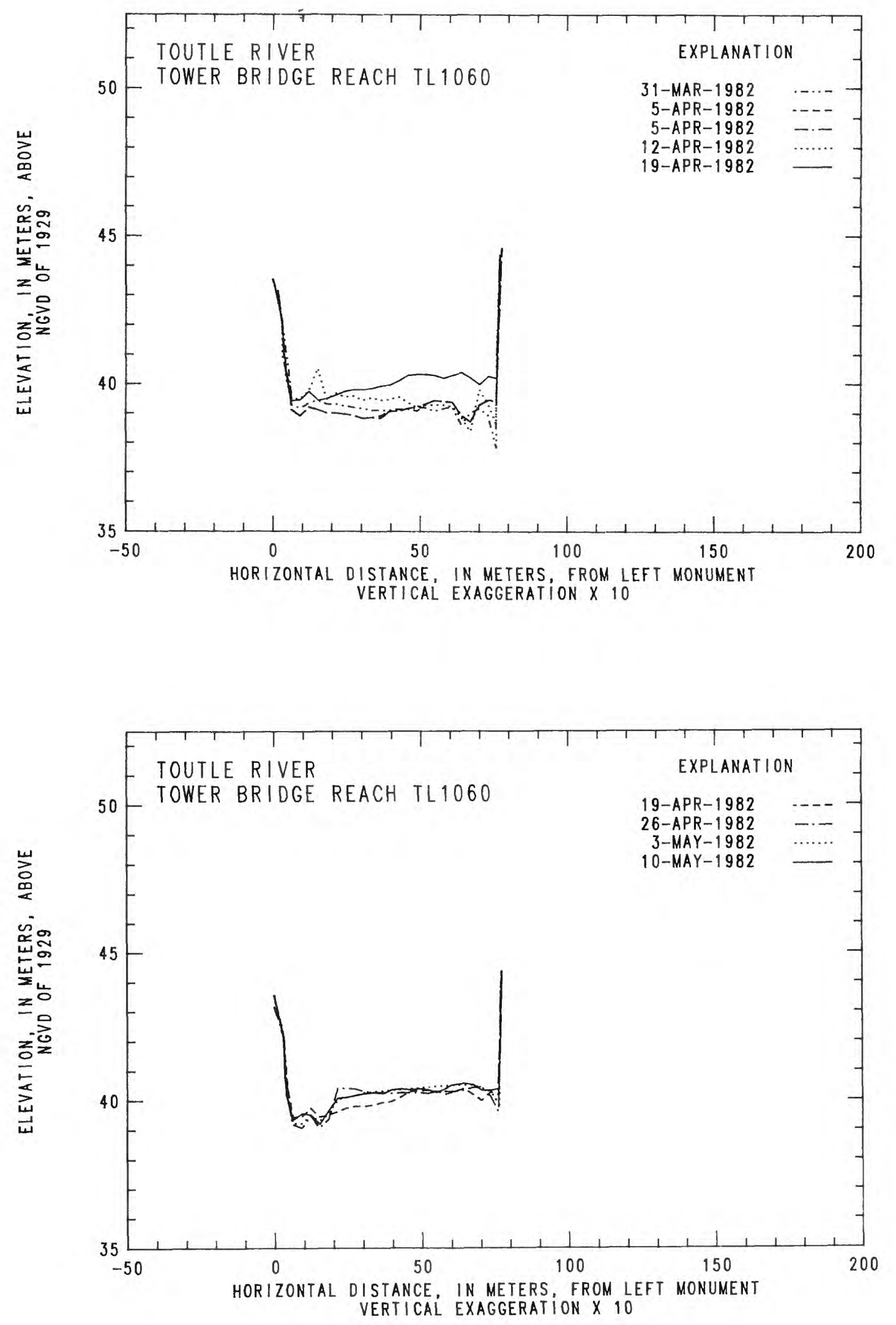

Figure 17.--Channel cross-section profiles for selected sites, Toutle River--Continued 

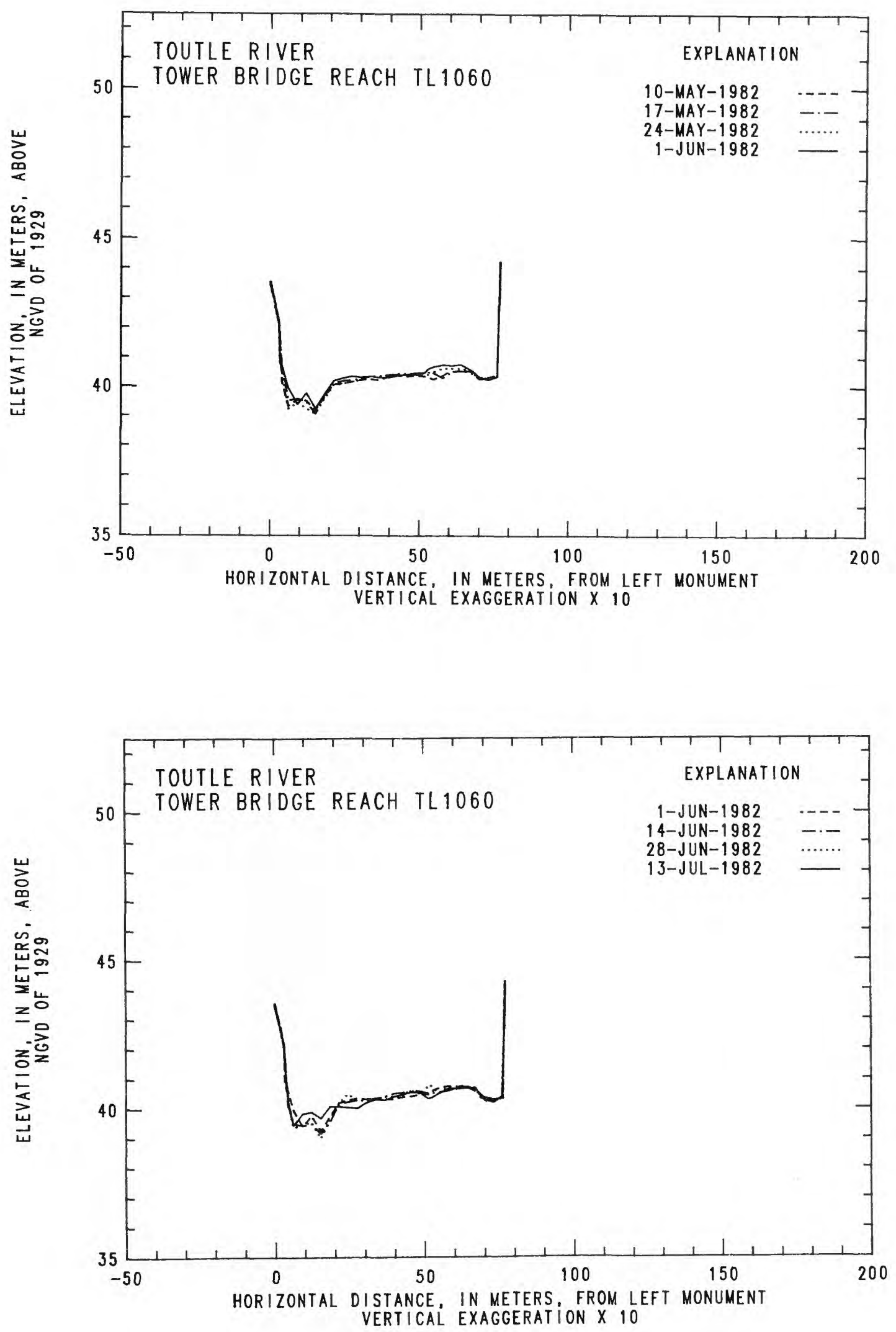

Figure 17.--Channel cross-section profiles for selected sites, Toutle River--Continued 

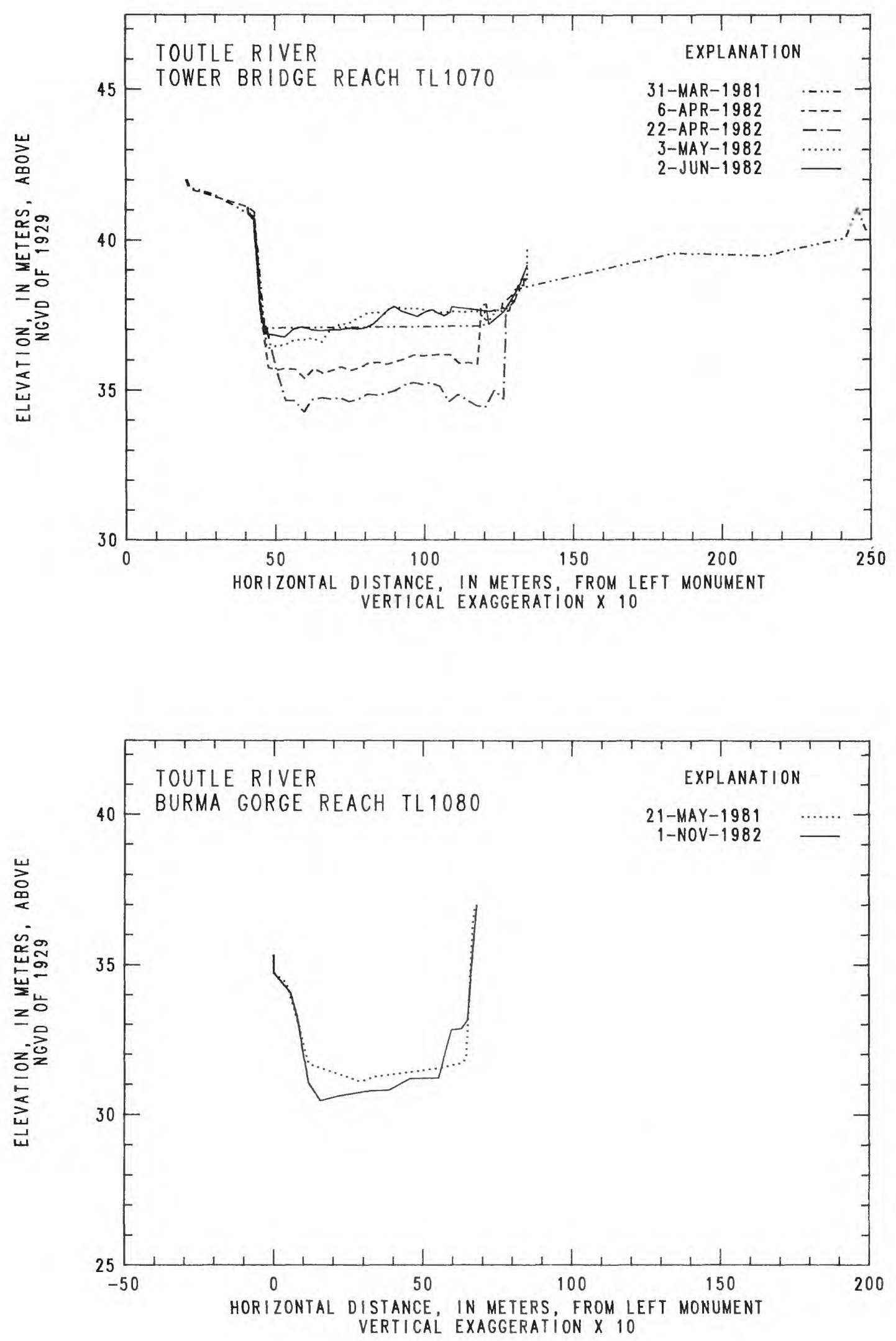

Figure 17.--Channel cross-section profiles for selected sites, Toutle River--Continued 
TABLE 1.--Drainage basin characteristics

\begin{tabular}{lccccc}
\hline & $\begin{array}{c}\text { Total } \\
\text { drainage } \\
\text { area } \\
(\mathrm{km} 2)\end{array}$ & $\begin{array}{c}\text { Gaged } \\
\text { drainage } \\
\text { area } \\
(\mathrm{km} 2)\end{array}$ & $\begin{array}{c}\text { Area within } \\
\text { blast area } \\
(\mathrm{km} 2)\end{array}$ & $\begin{array}{c}\text { Stream } \\
\text { 1ength } \\
(\mathrm{km})\end{array}$ & $\begin{array}{c}\text { Channe1 } \\
\text { gradient } \\
\text { range } \\
(\mathrm{m} / \mathrm{m})\end{array}$ \\
\hline $\begin{array}{l}\text { Green } \\
\begin{array}{l}\text { North Fork Tout1e } \\
\text { Water year 1981 } \\
\text { Water year 1982 }\end{array}\end{array}$ & 342 & 334 & 171 & 53 & $0.2-0.01$ \\
$\begin{array}{l}\text { South Fork Tout1e } \\
\begin{array}{l}728 \\
\text { Toutle }\end{array}\end{array}$ & 328 & $\begin{array}{c}617 \mathrm{a} \\
682\end{array}$ & $\begin{array}{c}448 \\
448\end{array}$ & $\begin{array}{c}52 \mathrm{~b} \\
63 \mathrm{~b}\end{array}$ & $\begin{array}{c}0.08-0.003 \\
0.15-0.003\end{array}$ \\
\end{tabular}

asee figure 6.

boes not include Green River basin.

CIncludes non-contributing area within North Fork Toutle basin.

$\mathrm{d}_{\text {At }}$ Tower Road near Silver Lake, Washington.

e Does not include North or South Fork Toutle basins. 

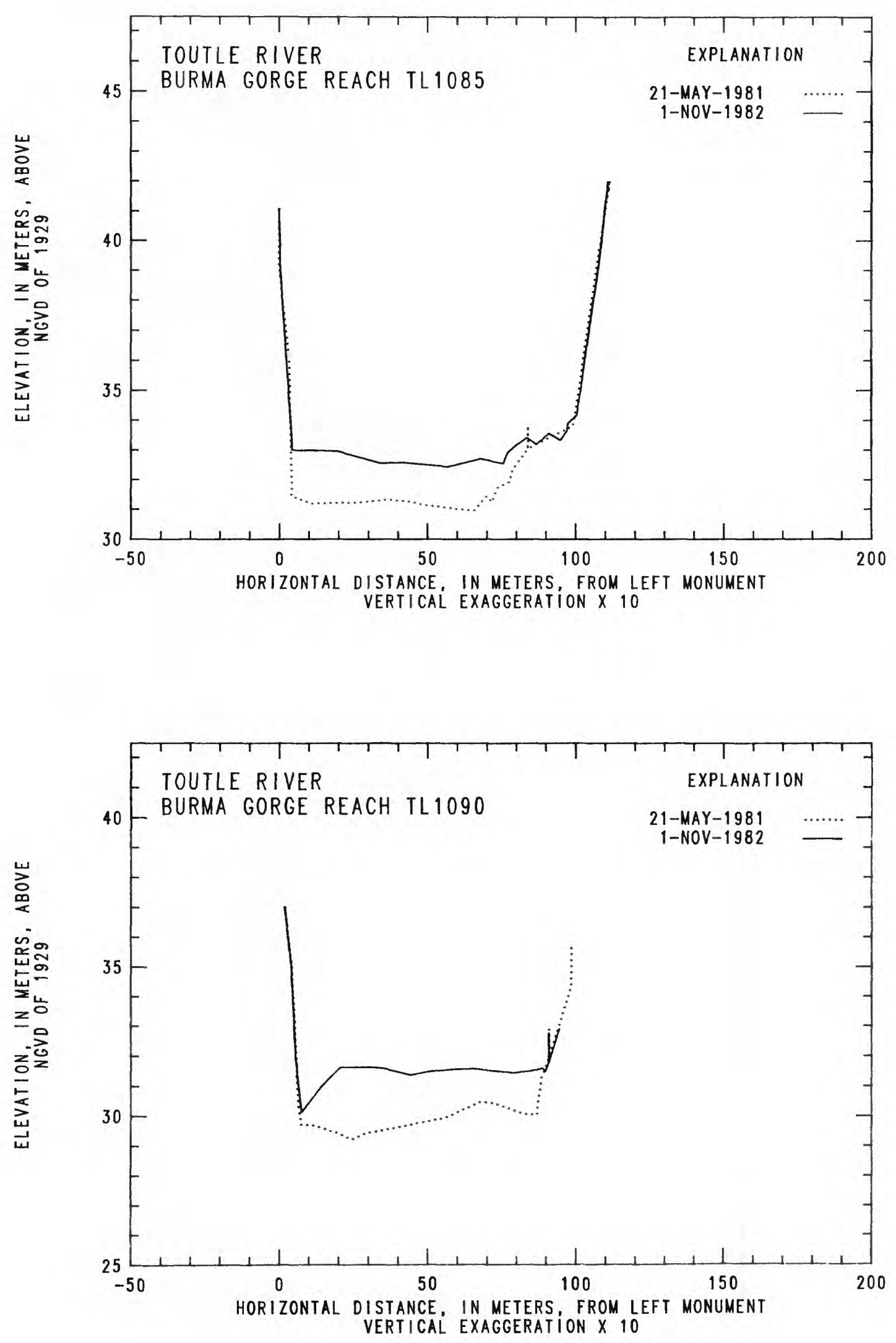

Figure 17.--Channel cross-section profiles for selected sites, Toutle River--Continued 

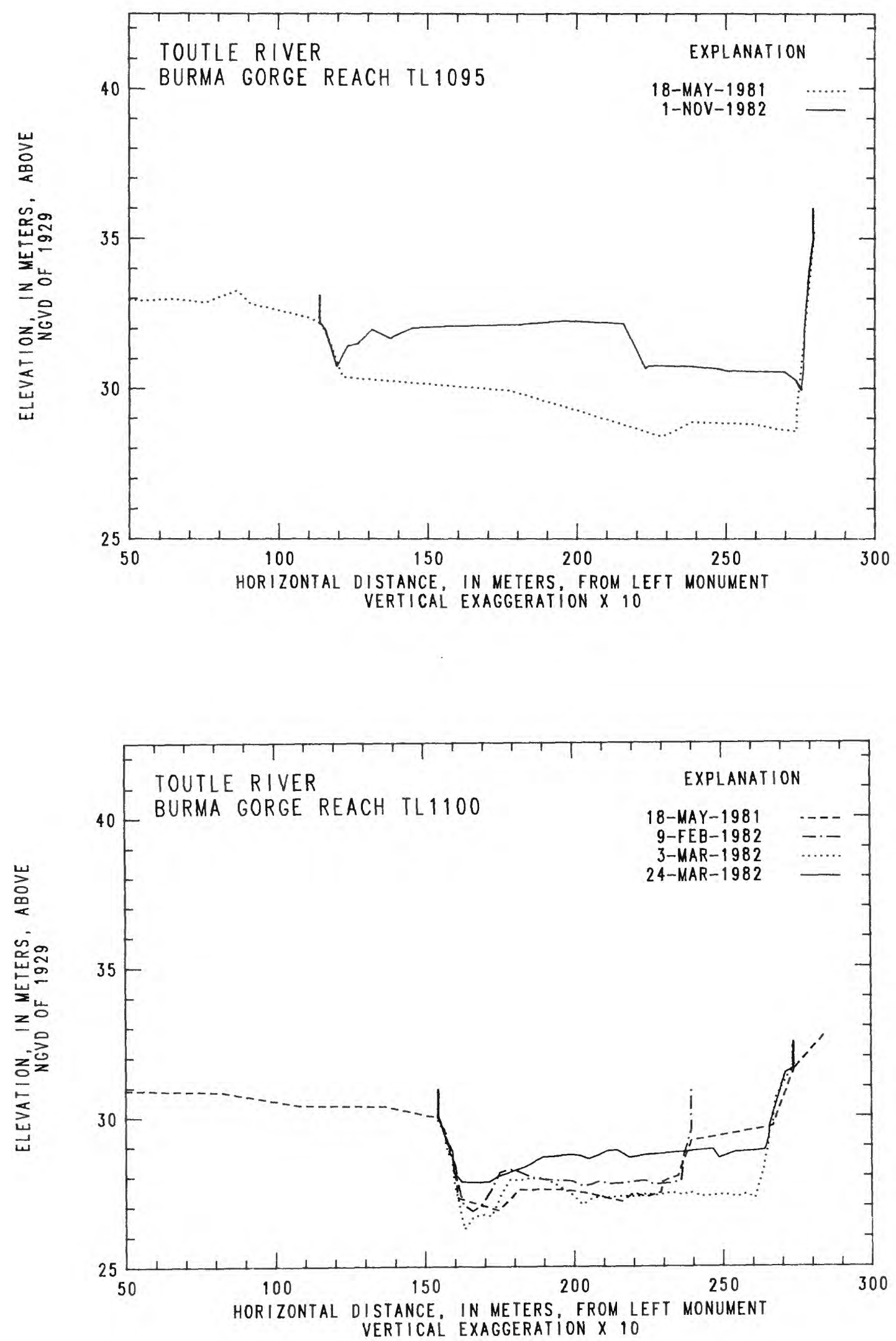

Figure 17.--Channel cross-section profiles for selected sites, Toutle River--Continued 

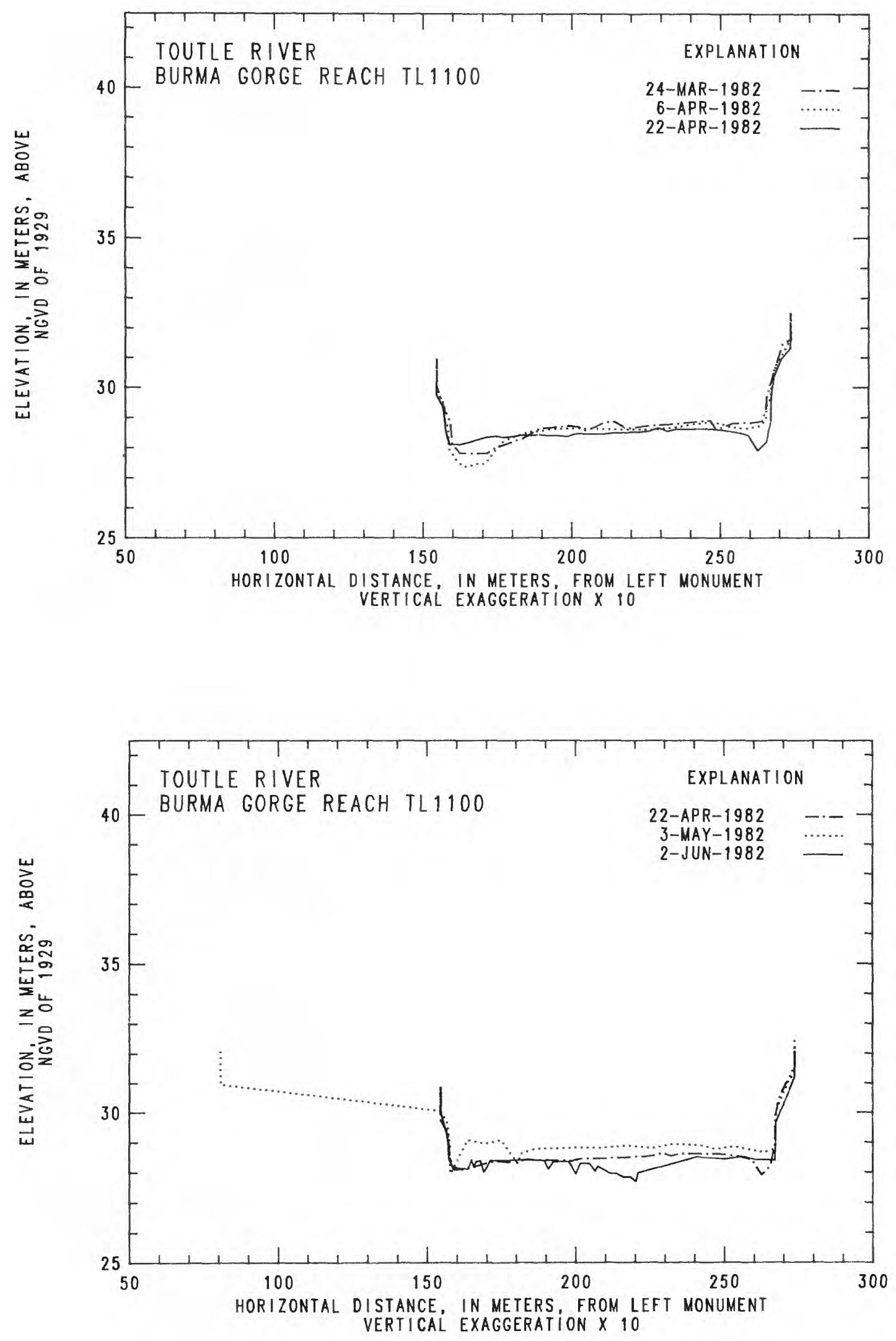

Figure 17.--Channel cross-section profiles for selected sites, Toutle River--Continued 

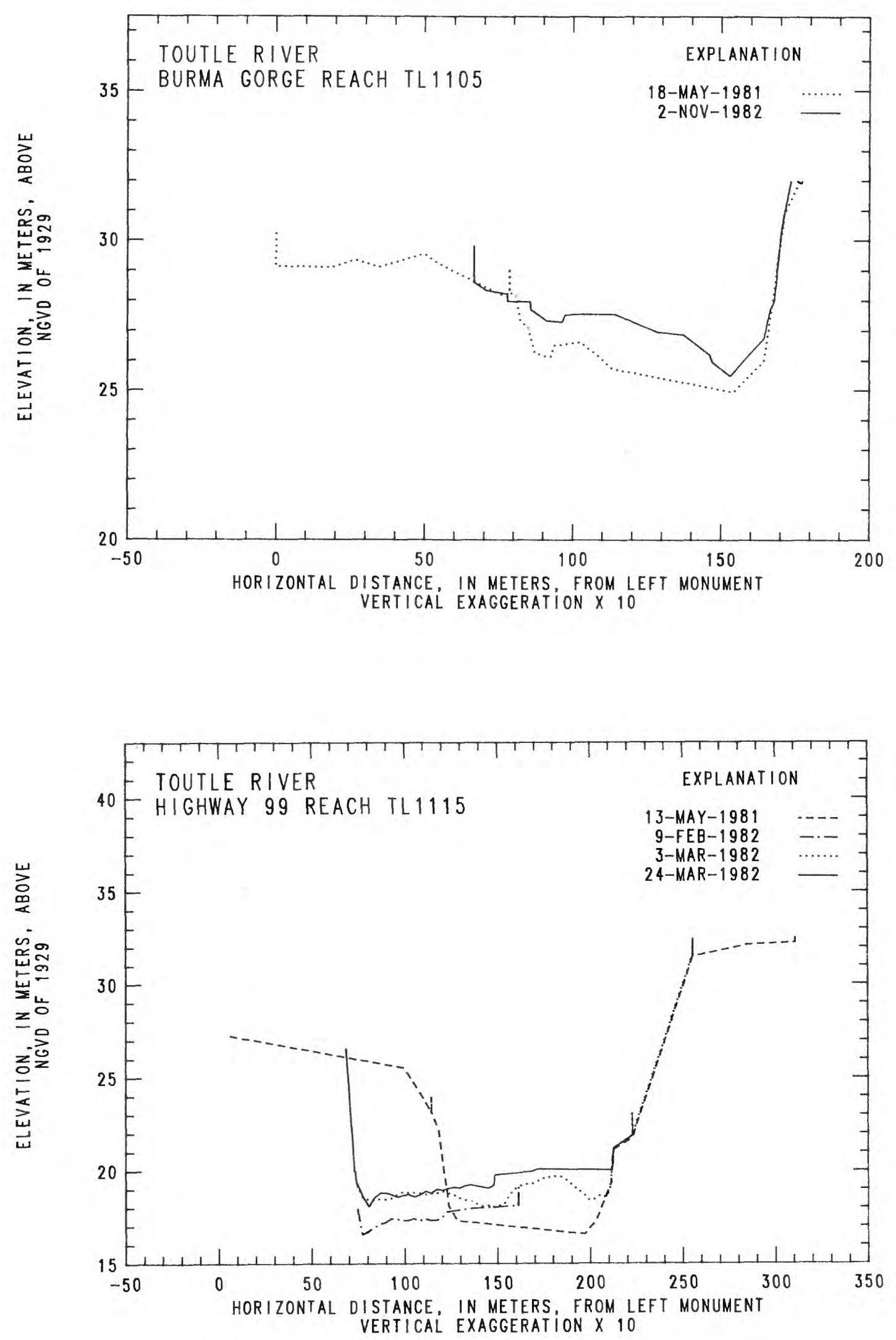

Figure 17.--Channel cross-section profiles for selected sites, Toutle River--Continued 

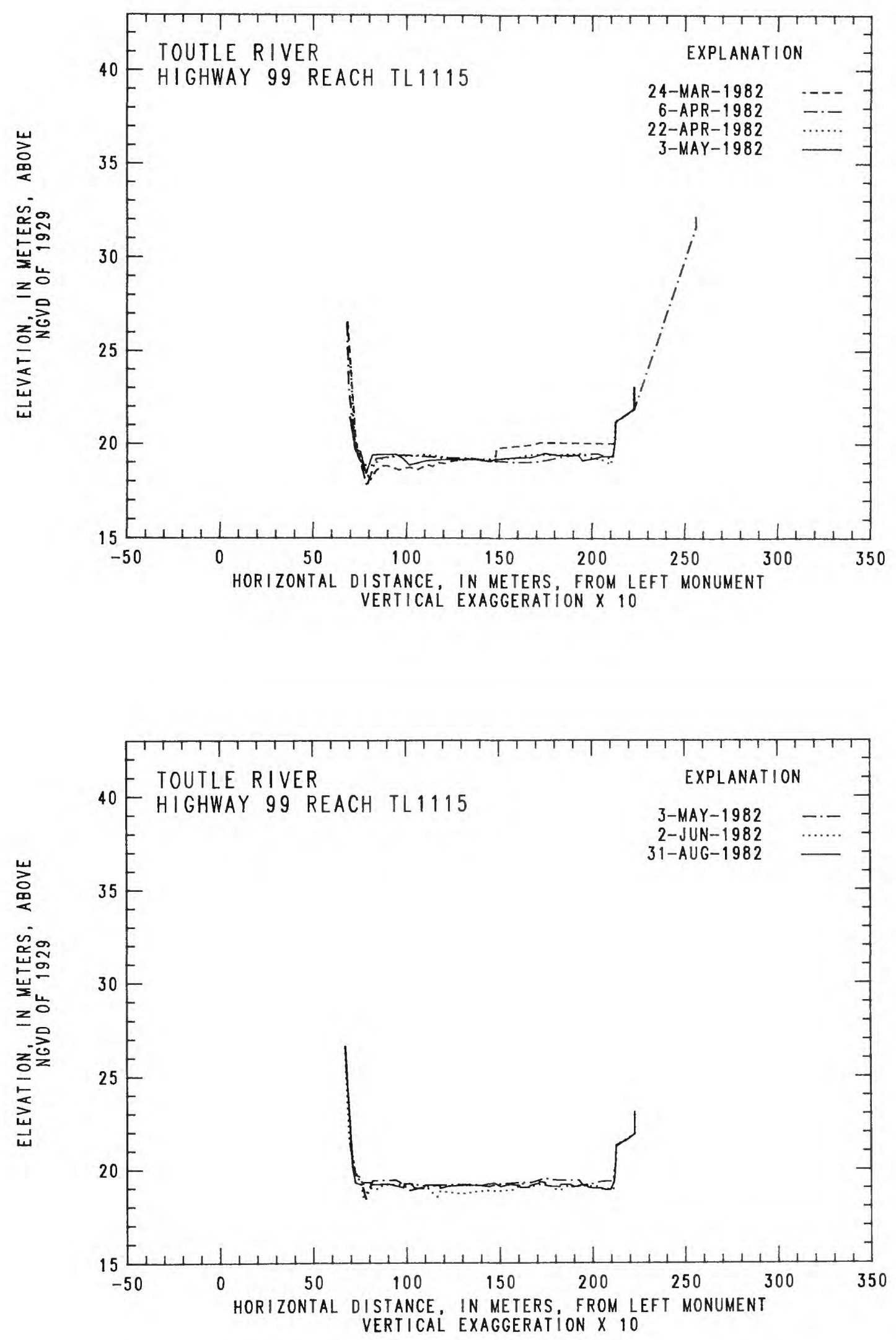

Figure 17.--Channel cross-section profiles for selected sites, Toutle River--Continued 

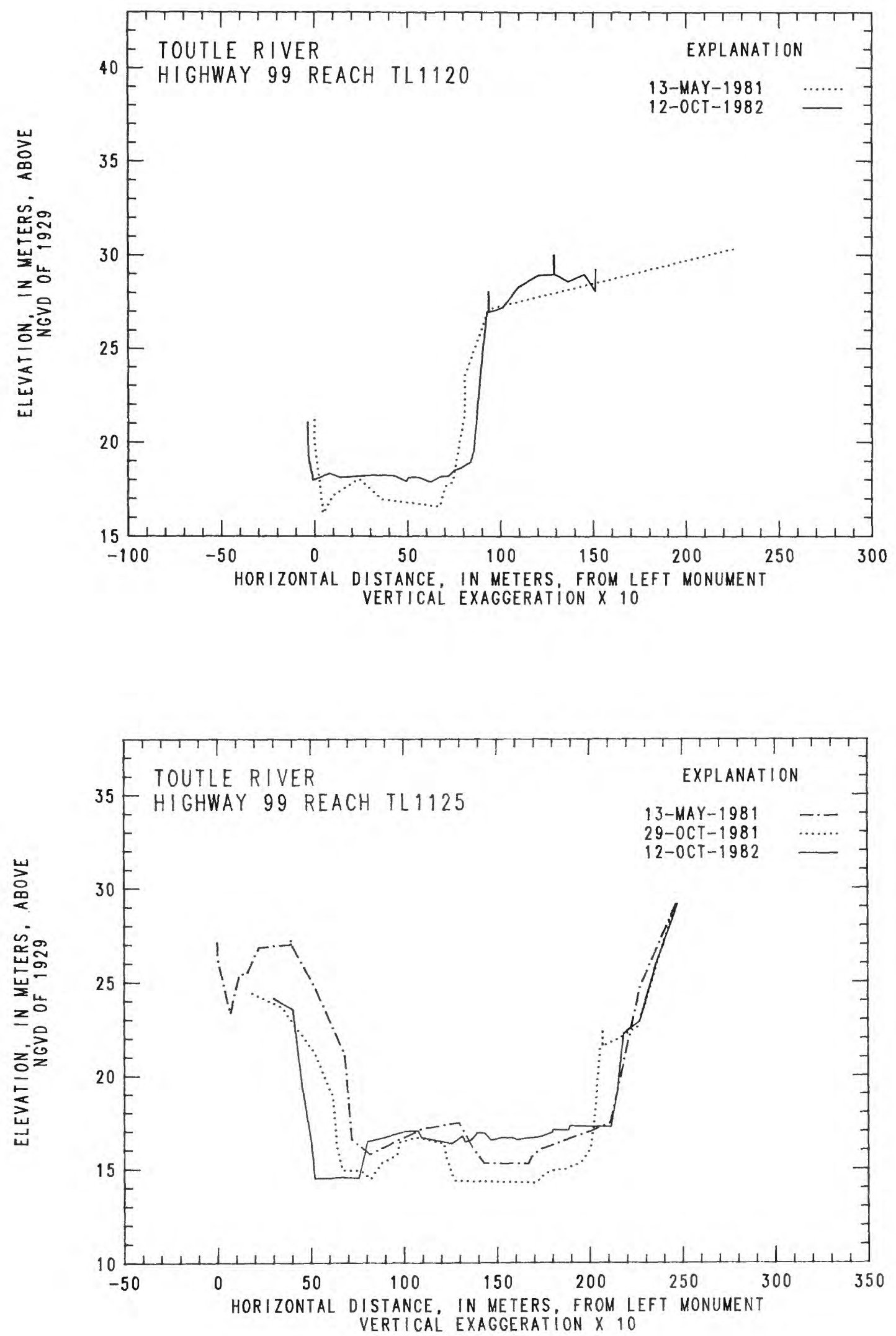

Figure 17.--Channel cross-section profiles for selected sites, Toutle River--Continued 


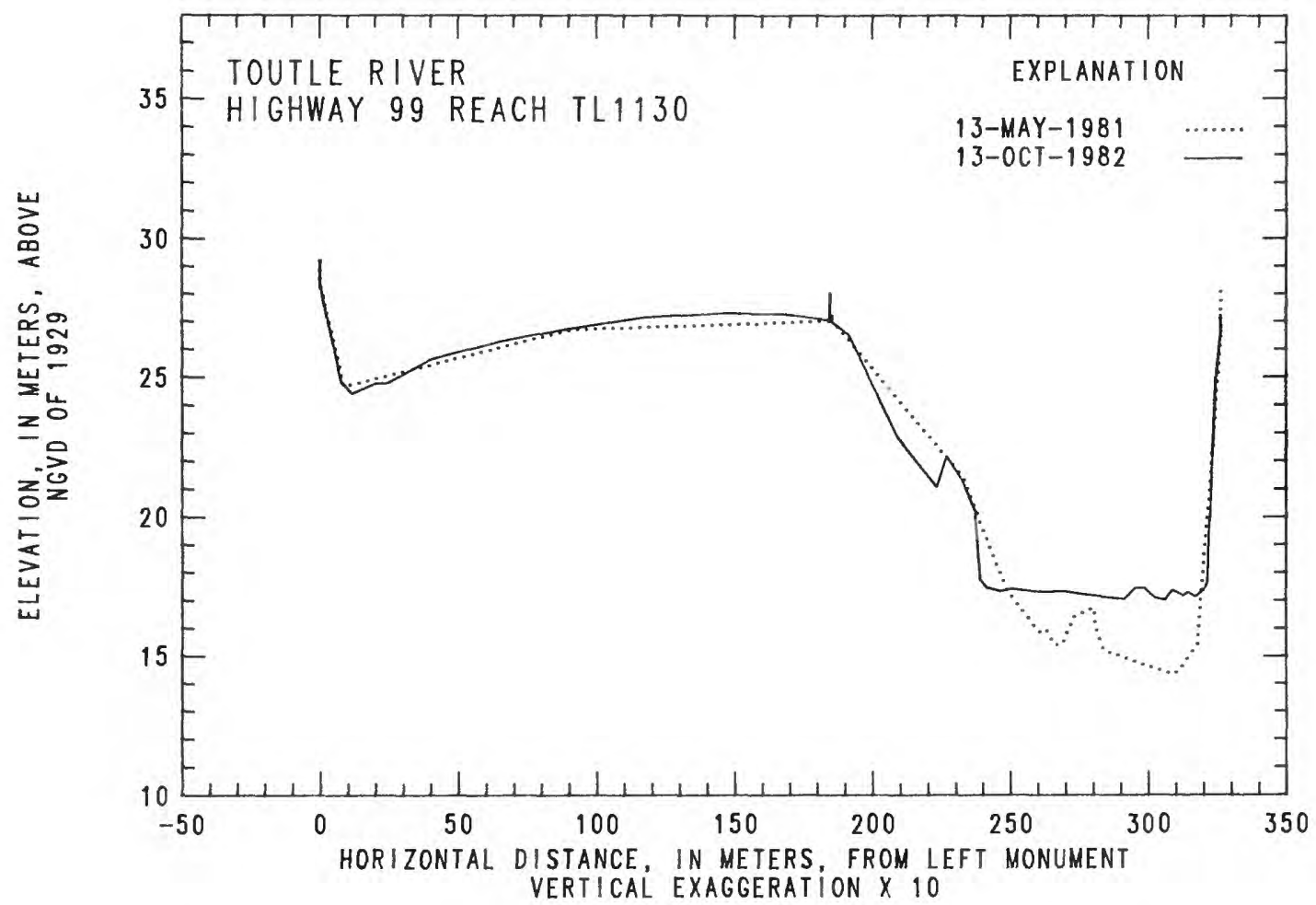

Figure 17.--Channel cross-section profiles for selected sites, Toutle River--Continued 

Most high flows in the North Fork Toutle basin have been induced by storm runoff. However, the largest peak discharge occurred on March 19, 1982 , when an explosive phase of an eruption melted snow in the crater of Mount St. Helens, generating a debris flow (table 2; Waitt and others, 1983). Smaller peaks have been generated as ponds and lakes on and adjacent to the debris- avalanche deposit have been breached. Rises in river stage that can be attributed to uncontrolled breaches occurred on August 27 and November 8, 1980, and on January 25 and February 13, 17, and 20, 1982 (fig. 7). Peak discharges at Kid Valley attributable to breakouts of impounded water range from $51 \mathrm{~m} 3 / \mathrm{s}$ to $477 \mathrm{~m} 3 / \mathrm{s}$.

In order to control sediment eroded from the debris-avalanche deposit, a debris retention structure was constructed below the toe of the avalanche deposit during the fall and winter of water year 1981 (between cross sections NF375 and NF390, fig. 2).

Water and suspended-sediment discharge data have been collected since June 1980 at Kid Valley, $11.1 \mathrm{~km}$ upstream from the confluence of North Fork Toutle and South Fork Toutle Rivers (KIDW, fig. 1). Fifty-five cross sections were established along the North Fork Toutle and its major tributaries between the summer of 1980 and the end of water year 1982 . The majority of these cross sections are surveyed annually, but 14 key indicator sections are surveyed monthly or after large storms during the fal1, winter, and spring. Most of the cross sections are grouped into 12 clusters (table 2 and figs. 2, 3, 4, 5, 12 and 13).

\section{South Fork Toutle River}

The South Fork Toutle River has its headwaters on the west flank of Mount St. Helens, and flows west-northwest to its confluence with the North Fork Toutle River (fig. 1). A small area in the headwaters of the drainage was affected by the blast on May 18, 1980 (table 1). Tephra deposits in most of the South Fork Toutle drainage are negligible, but are up to $5 \mathrm{~cm}$ thick on the flanks of Mount St. Helens. A lahar, generated from water-saturated volcanic ejecta during the intial stages of the May 18, 1980, eruption, flowed the length of the South Fork Toutle River (Janda and others, 1981). A second, smaller lahar was generated during the afternoon of May 1981, and it also flowed the length of the mainstream.

A debris retention structure was constructed on the 1ower South Fork Toutle just upstream of cross section SF760 (fig. 5) during the fall and winter of water year 1981. After more than a year of operation, the structure was removed to allow for migratory fish passage. A sediment stabilization basin was operated downstream of the debris retention structure during the summer and fall of 1980 . 


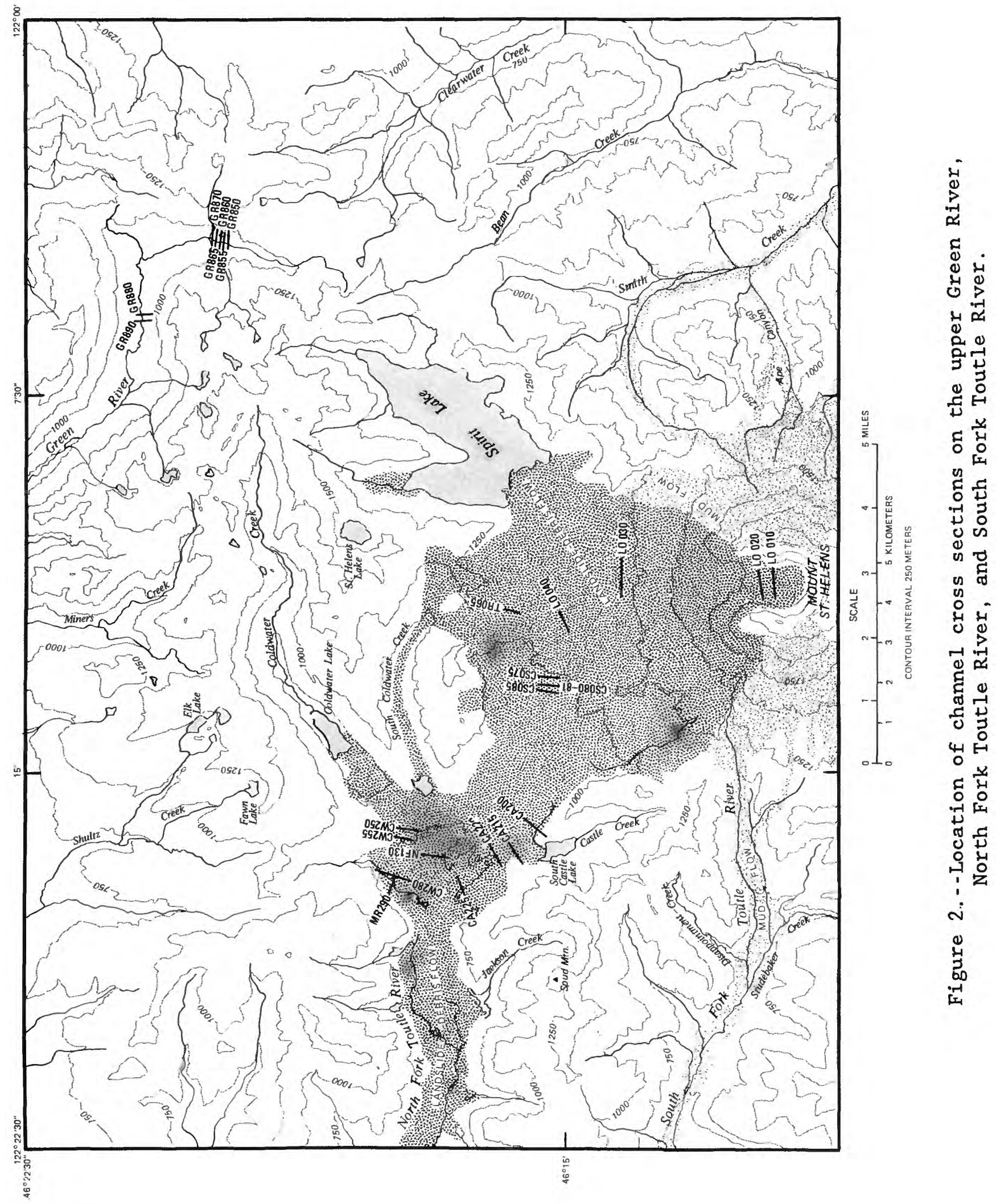




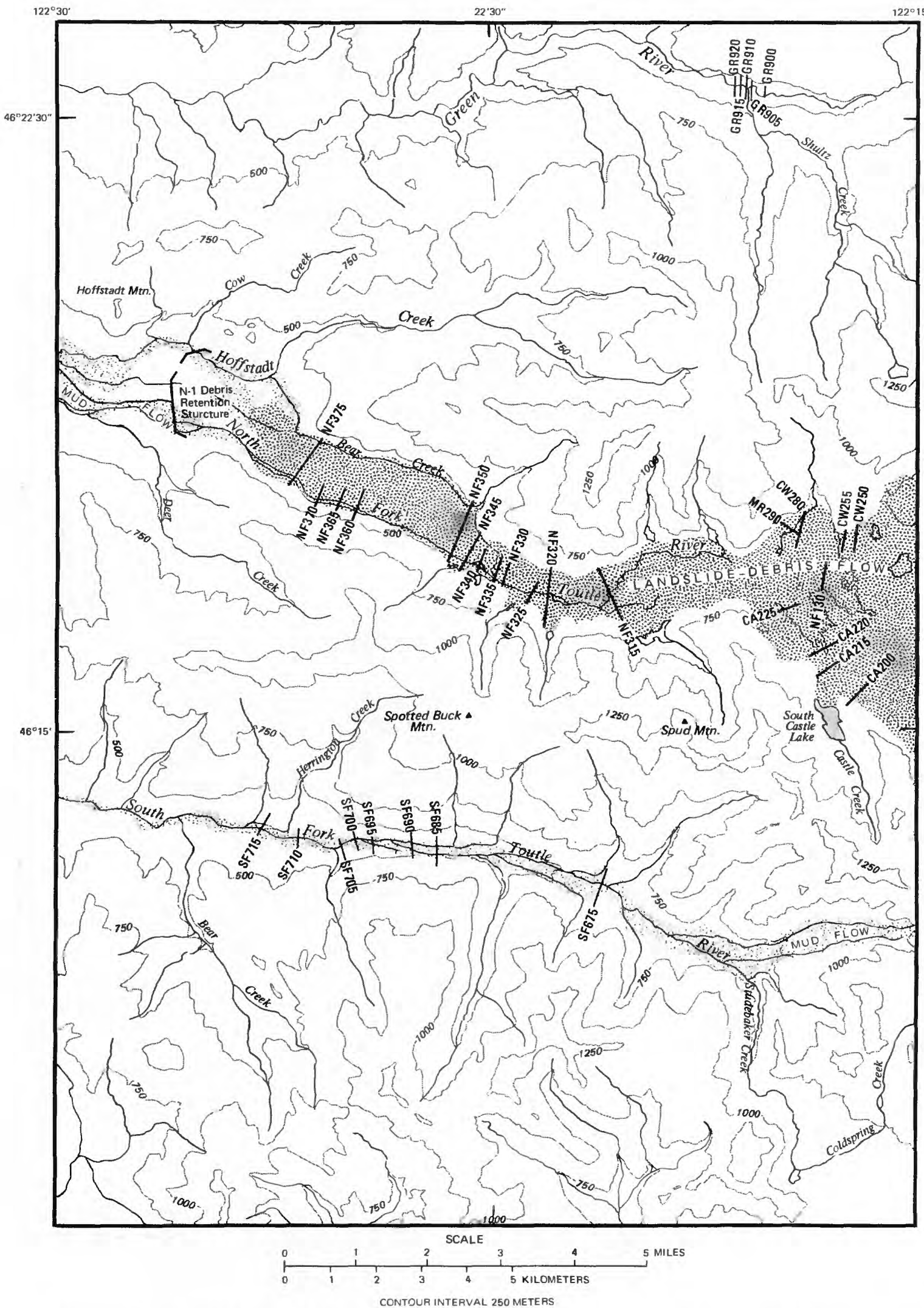

Figure 3.--Location of channel cross sections on the Green River, North Fork Toutle River and its tributaries, and South Fork Toutle River. 


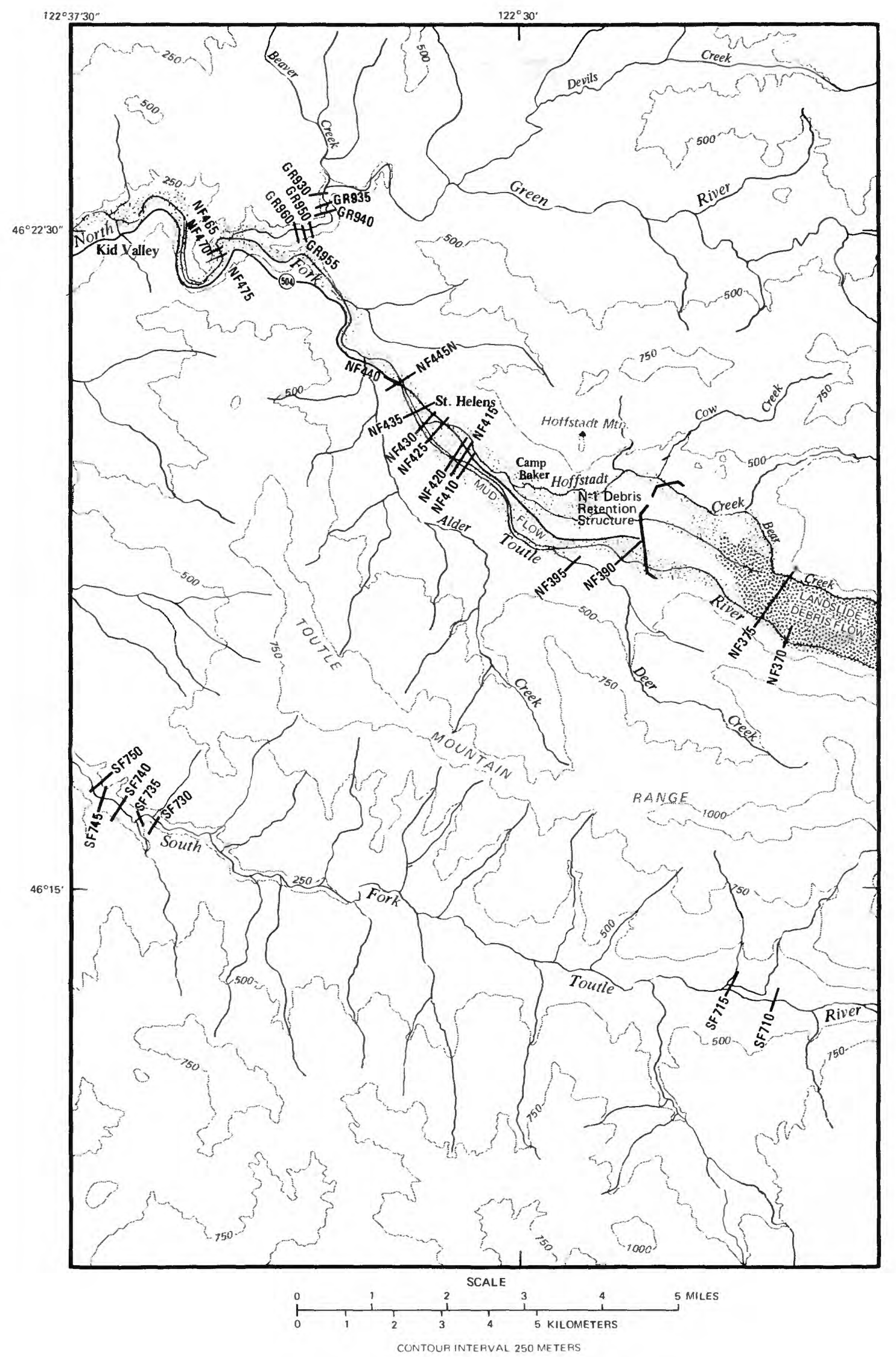

Figure 4.--Location of channel cross sections on the lower Green River and North Fork Toutle River and its tributaries, and South Fork Toutle River. 
TABLE 2.--Peak discharge and unit discharge for major discharge events, Toutle River basin.

[Peak discharge in $\mathrm{m}^{3} / \mathrm{sec}^{-1}$; unit discharge in $\mathrm{m}^{3} / \mathrm{sec} / \mathrm{km}$ )]

Basin name, station name, ID number

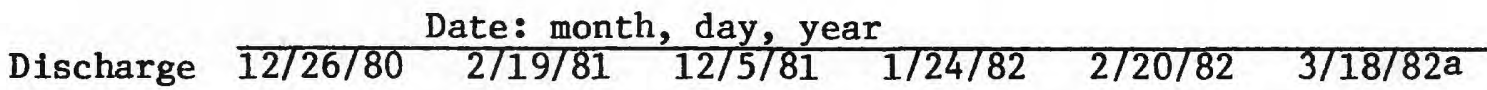

\begin{tabular}{|c|c|c|c|c|c|c|c|}
\hline $\begin{array}{l}\text { Green River } \\
\text { (GREW) } \\
14240800\end{array}$ & $\begin{array}{l}\text { Peak } \\
\text { Unit }\end{array}$ & $\begin{array}{l}178 \\
0.533\end{array}$ & $\begin{array}{r}127.381 \\
\end{array}$ & $\begin{array}{r}167.500 \\
.500\end{array}$ & $\begin{array}{r}436 \\
1.31\end{array}$ & $\begin{array}{r}168.504 \\
.504\end{array}$ & $\begin{array}{l}\mathrm{n} / \mathrm{a} \\
\mathrm{n} / \mathrm{a}\end{array}$ \\
\hline $\begin{array}{l}\text { North Fork } \\
\text { Toutle River } \\
\text { (KIDW) } \\
14241100\end{array}$ & $\begin{array}{l}\text { Peak } \\
\text { Unit }\end{array}$ & b & $\mathrm{b}$ & $\begin{array}{l}351 \\
0.556\end{array}$ & $\begin{array}{r}648 \\
1.03\end{array}$ & $\begin{array}{l}960 \\
1.52\end{array}$ & $\begin{array}{l}963 \\
\mathrm{n} / \mathrm{a}\end{array}$ \\
\hline $\begin{array}{l}\text { South Fork } \\
\text { Toutle River } \\
\text { (TOSW) } \\
14241490\end{array}$ & $\begin{array}{l}\text { Peak } \\
\text { Unit }\end{array}$ & b & b & $\begin{array}{l}170 \\
0.560\end{array}$ & $\begin{array}{r}258 \\
.851\end{array}$ & $\begin{array}{r}193.637 \\
.637\end{array}$ & $\mathrm{n} / \mathrm{a}$ \\
\hline $\begin{array}{l}\text { Toutle River } \\
\text { at Tower Road } \\
\text { (TOTW) } \\
14242580\end{array}$ & $\begin{array}{l}\text { Peak } \\
\text { Unit }\end{array}$ & $\mathrm{b}$ & $\mathrm{b}$ & $\begin{array}{l}518 \\
0.421\end{array}$ & $\begin{array}{r}447.363 \\
.363\end{array}$ & $\begin{array}{r}1,080 \\
.879\end{array}$ & $\begin{array}{l}651 \\
\mathrm{n} / \mathrm{a}\end{array}$ \\
\hline $\begin{array}{l}\text { Toutle River } \\
\text { at Highway } 99 \\
\text { (THIW) } \\
14242690\end{array}$ & $\begin{array}{l}\text { Peak } \\
\text { Unit }\end{array}$ & $\begin{array}{l}623 \\
0.531\end{array}$ & $\begin{array}{r}708 \\
.603\end{array}$ & $\begin{array}{r}552.452 \\
.45\end{array}$ & $\begin{array}{l}994.814 \\
.814\end{array}$ & $\begin{array}{r}1,080 \\
.885\end{array}$ & $\begin{array}{l}425 \\
\mathrm{n} / \mathrm{a}\end{array}$ \\
\hline $\begin{array}{l}\text { Cowlitz River } \\
\text { at Castle Rockc } \\
\text { (CASW) } \\
14243000\end{array}$ & $\begin{array}{l}\text { Peak } \\
\text { Unit }\end{array}$ & $\begin{array}{l}1,330 \\
0.236\end{array}$ & $\begin{array}{r}1,360 \\
.241\end{array}$ & $\begin{array}{r}1,090 \\
.192\end{array}$ & $\begin{array}{r}1,850 \\
.325\end{array}$ & $\begin{array}{r}1,790 \\
.315\end{array}$ & $\begin{array}{l}513 \\
\mathrm{n} / \mathrm{a}\end{array}$ \\
\hline
\end{tabular}

aFlow of March 19, 1982, was generated from a point source in the North Fork Toutle basin, and it did not affect the Green River or the South Fork Toutle River.

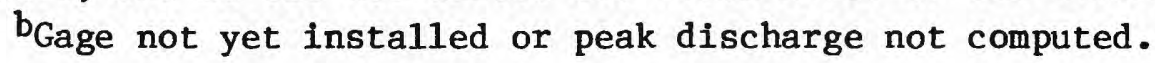

$c_{\text {Regulated flow. }}$ 
Water and suspended-sediment discharge data have been collected since February 1981 at Camp 12, $8.0 \mathrm{~km}$ upstream from the confluence of North Fork Toutle and South Fork Toutle Rivers (TOSW, fig. 1). Twenty-five cross sections were established along the South Fork Toutle between the summer of 1980 and the end of water year 1982. The majority of these cross sections are surveyed annually, but 4 key indicator sections are surveyed monthly or after large storms during the fall, winter, and spring. Most of the cross sections are grouped into 4 clusters (table 2 and figs. 2, 3, 5, 14 and 15).

\section{Toutle River}

The Toutle River is formed at the confluence of the north and south forks of the Toutle River. It flows west through a series of bedrock gorges separated by wide alluvial valleys, to its mouth at the Cowlitz River (fig. 1).

Lahars from both the South Fork Toutle and the North Fork Toutle flowed down the main Toutle River on May 18, 1980 (Janda and others, 1981; Cummans, 1981). Since 1980, large volumes of sediment have been delivered to the Toutle from both these rivers. Two sediment stabilization basins have been in operation perdiodically since the fall of water year 1981, one near cross section TL1030 at the former site of the town of Tower, and one between cross sections TL1105 and TL1115, about $3 \mathrm{~km}$ upstream of the mouth of the Toutle River (figs. 5 and 6 ). Dredging on the Cowlitz River near the mouth of the Toutle has lowered base level along the lower reaches of the Toutle, causing periodic channel degradation.

Along most of the Toutle River, the valley is narrow and bounded by bedrock walls; bedrock outcrops on the banks and channel bottom are common. Channel slopes are between 0.0015 and 0.0043 along the lower Toutle in these gorges, and beween 0.0056 and 0.0071 in the gorges along the upper mainstem Toutle. Spool and Highway 99 reaches (table 3 ) are alluvial, and the valley is wide. Channel slopes are 0.0035 in Spool reach and 0.0013 in Highway 99 reach (fig. 5 and 6 ).

Gaging stations were established near Castle Rock in May 1980, $1.6 \mathrm{~km}$ upstream from the mouth of the Tout1e River (THIW, fig. 1), and near Silver Lake in March 1981, $10.5 \mathrm{~km}$ upstream from the mouth (TOTW, fig. 1). Twenty cross sections were established along the mainstem Toutle River in four clusters (table 3 and figs. 5, 6, 16, and 17). Three of these cross sections are surveyed monthly or after large storms. 



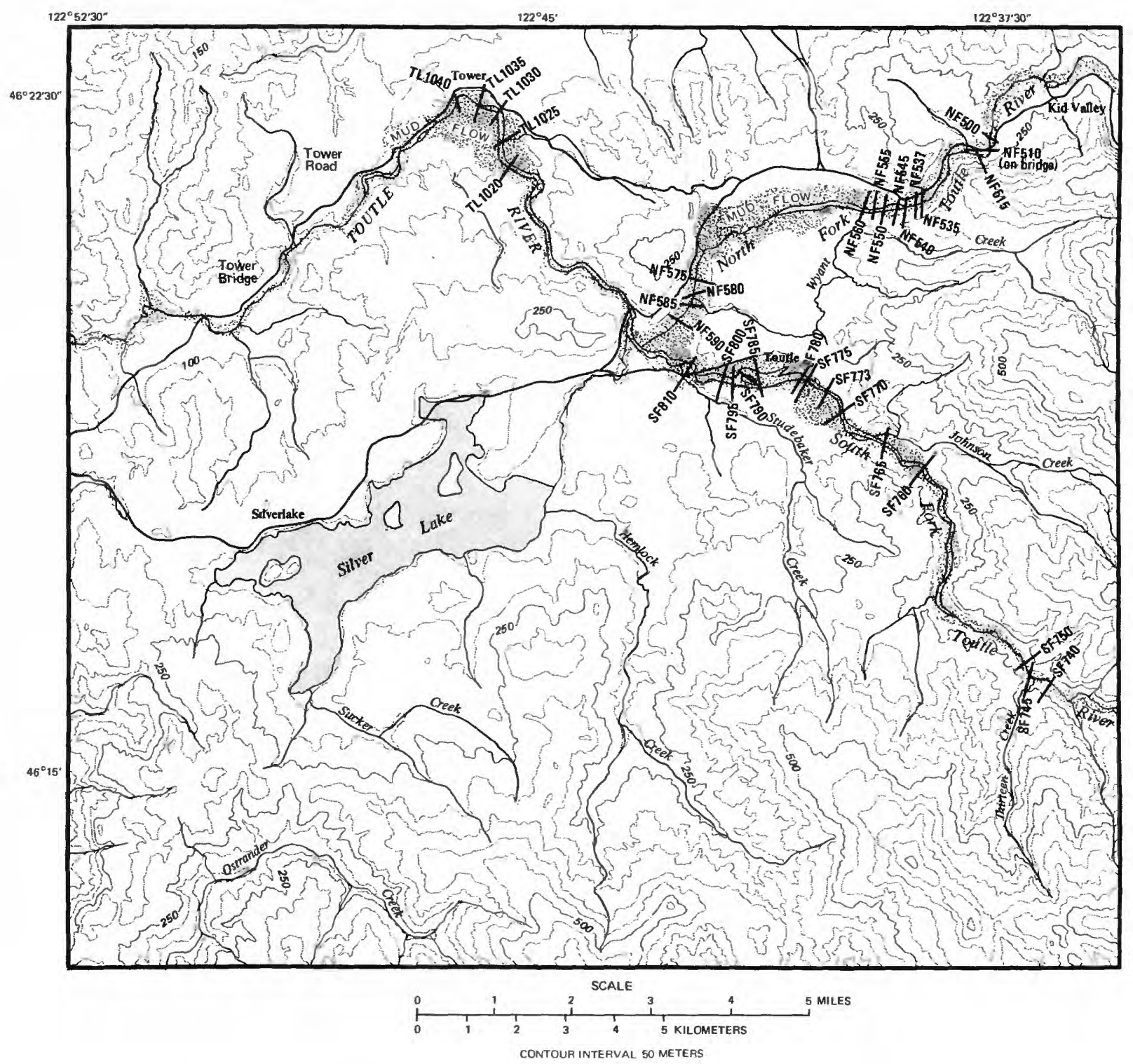

Figure 5.--Location of channel cross sections on the upper Toutle River, lower North Fork Toutle River, and lower South Fork Toutle River. 


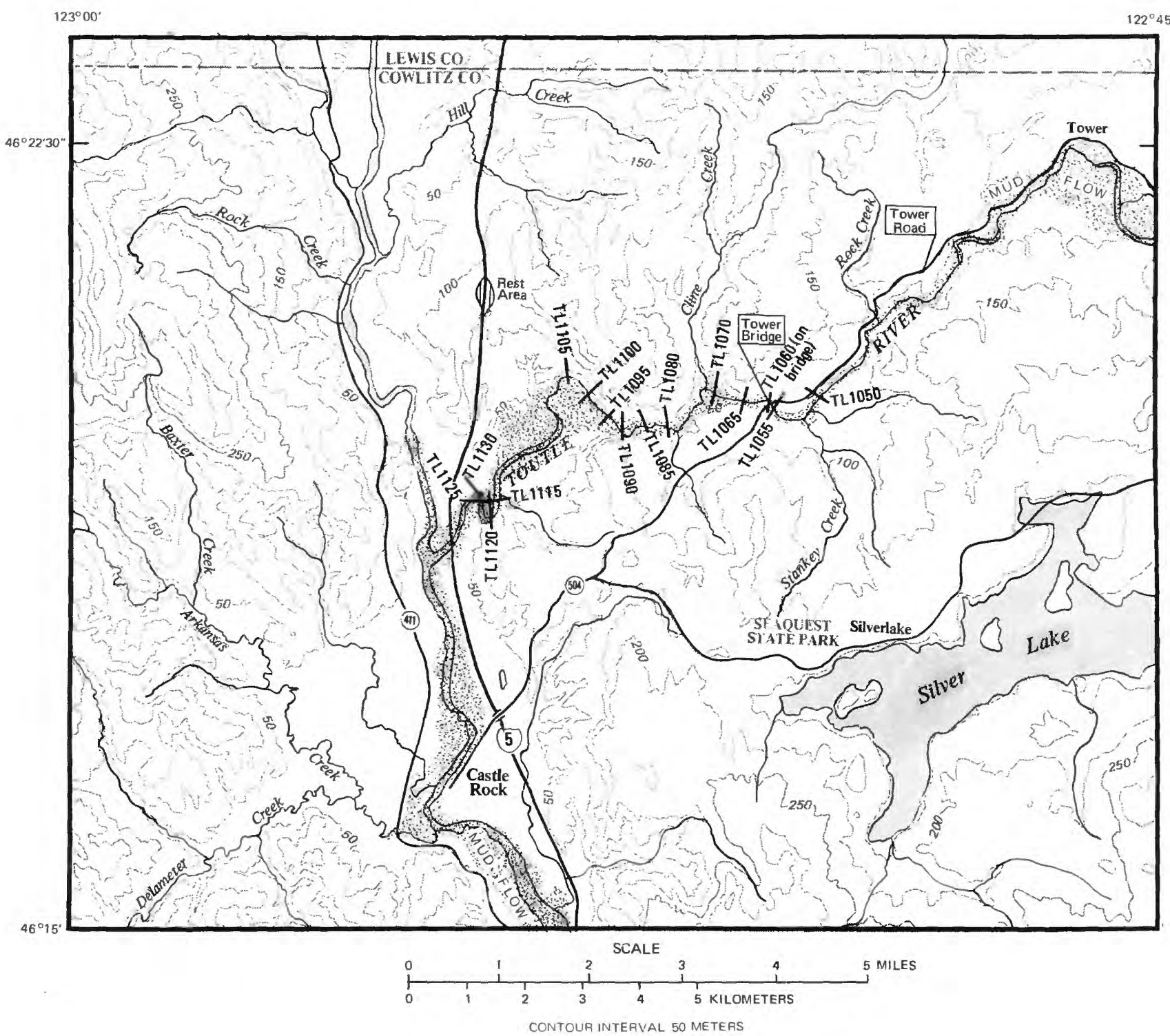

Figure 6.--Location of channel cross sections on the lower Toutle River. 


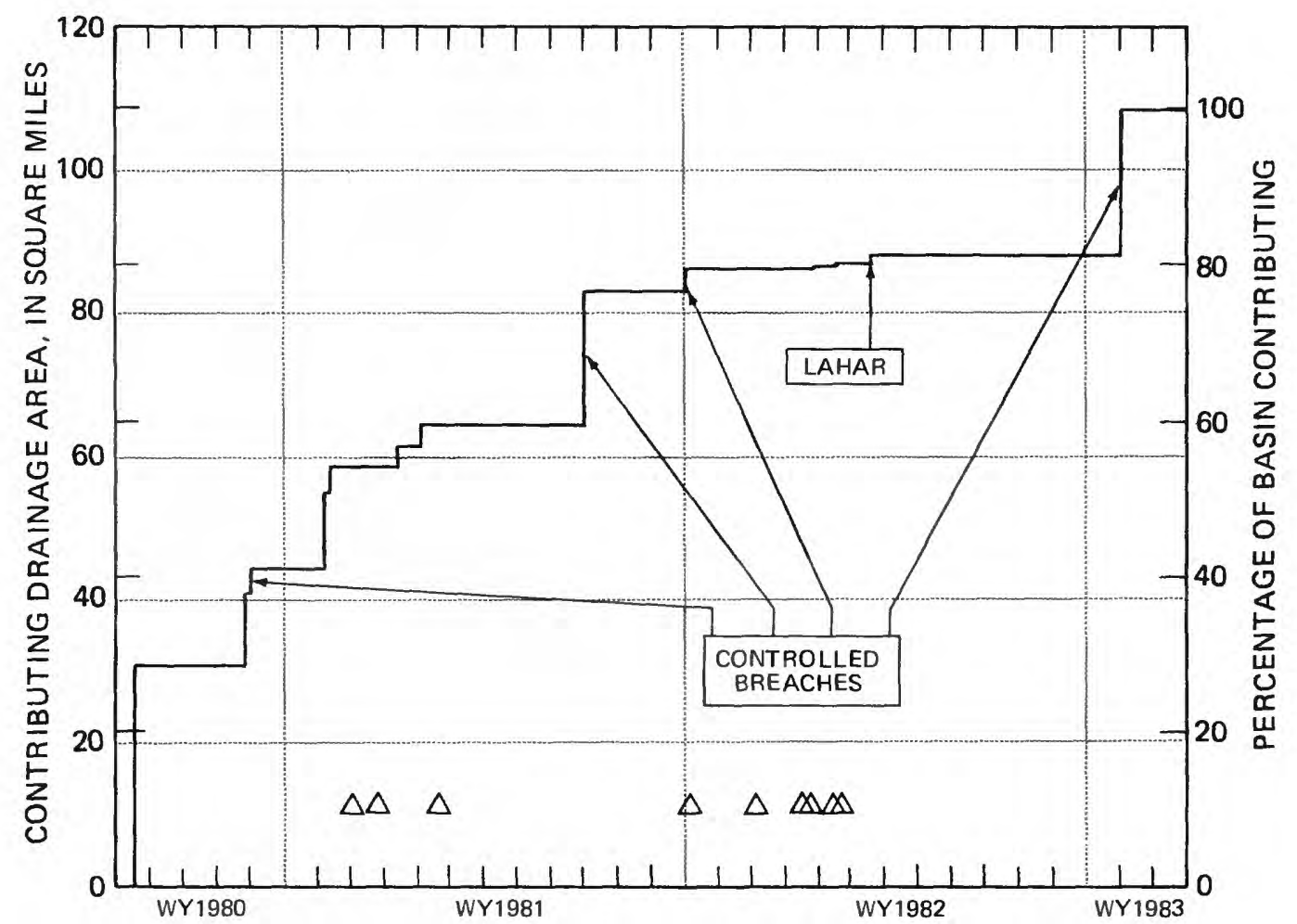

Figure 7.--Drainage integration, with time, of the upper North Fork Toutle River basin, above the $\mathrm{N}-1$ debris-retention structure. 


\section{HYDROLOGY}

Mount St. Helens is located on the west side of the Cascade Range in southern Washington. Average annual precipitation in the Toutle River drainage basin varies from about $1,100 \mathrm{~mm}$ in the valleys near sea level to more than $3,500 \mathrm{~mm}$ at altitudes above $1,000 \mathrm{~m}$ (Philips, 1974). Most precipitation occurs during a well-defined winter rainy season, which begins about October, peaks in December or January, and declines into the spring. During this period, rainfall usually occurs as 1 ight- to moderate-intensity rain, rather than as heavy rain. Freezing level may range from sea leve1 to above $1,000 \mathrm{~m}$ throughout the winter. Midwinter snowline is typically between about 750 and $1,200 \mathrm{~m}$ above sea level. Snow accumulation ranged from zero at lower elevations to more than $7.6 \mathrm{~m}$ above $1,500 \mathrm{~m}$. Density of the snowpack increased from about 25 to 45 percent water equivalent between early winter and April (Pacific Northwest Basins Commission, 1970). The largest flows (both pre- and post-eruption) occur when relatively warm heavy rains fall on snow, and snownelt supplements the rainfall runoff.

Figures 8 and 9 are annual hydrographs of daily mean discharge measured at gaging stations on the North Fork Toutle River near Kid Valley (fig. 5) and the Cowlitz River at Castle Rock (fig. 6). Table 1 presents peak discharge of the largest flows to occur during water years 1981 and 1982. The five highest peak flows were produced by storms that occurred Dec. 26, 1980; Feb. 19 and Dec. 5, 1981; and Jan. 24 and Feb. 20, 1982 . 

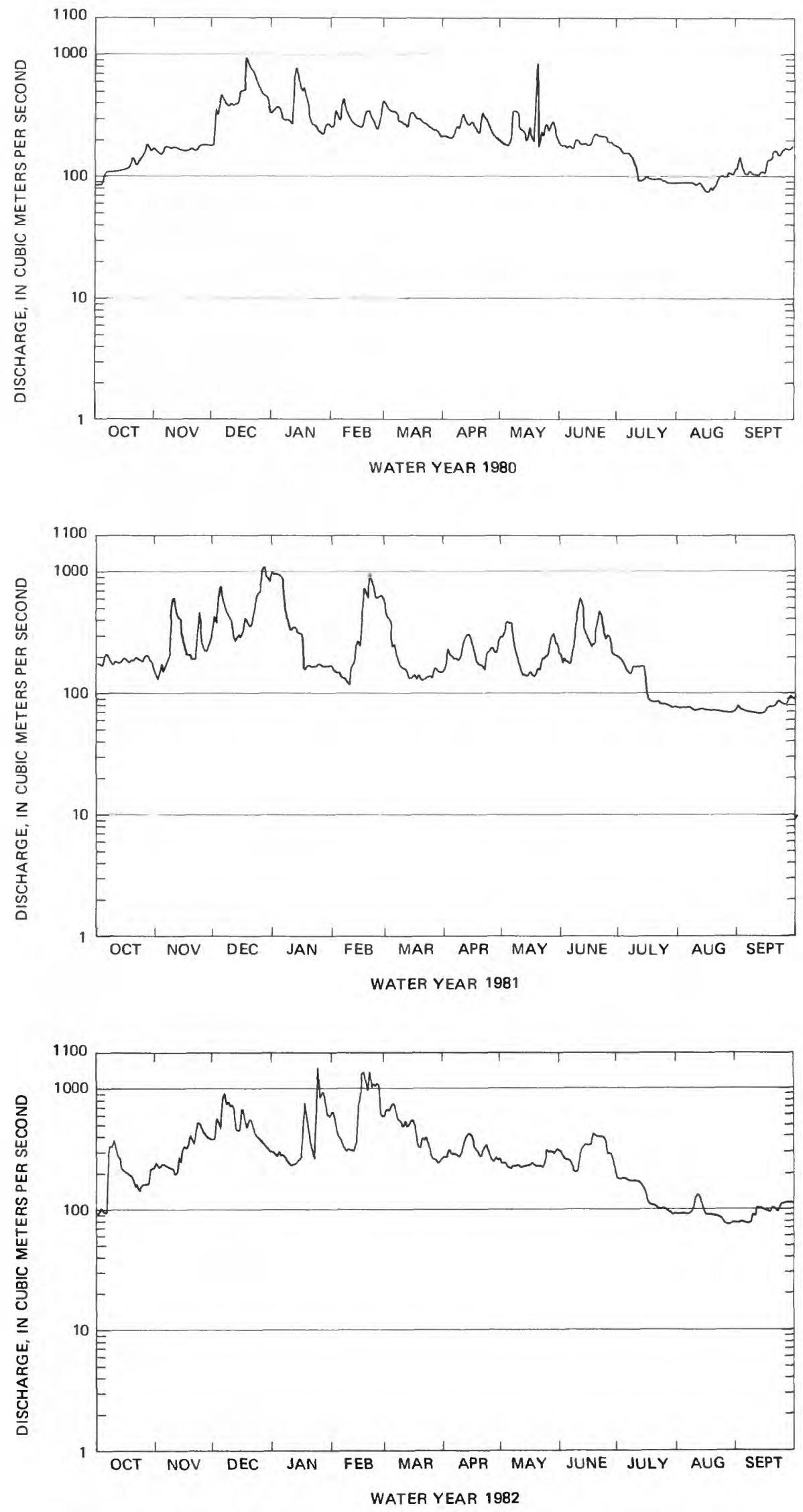

Figure 8. - Annual hydrograph of daily mean discharge for Cowlitz River at Castle Rock, Washington, water years 1980-82. 

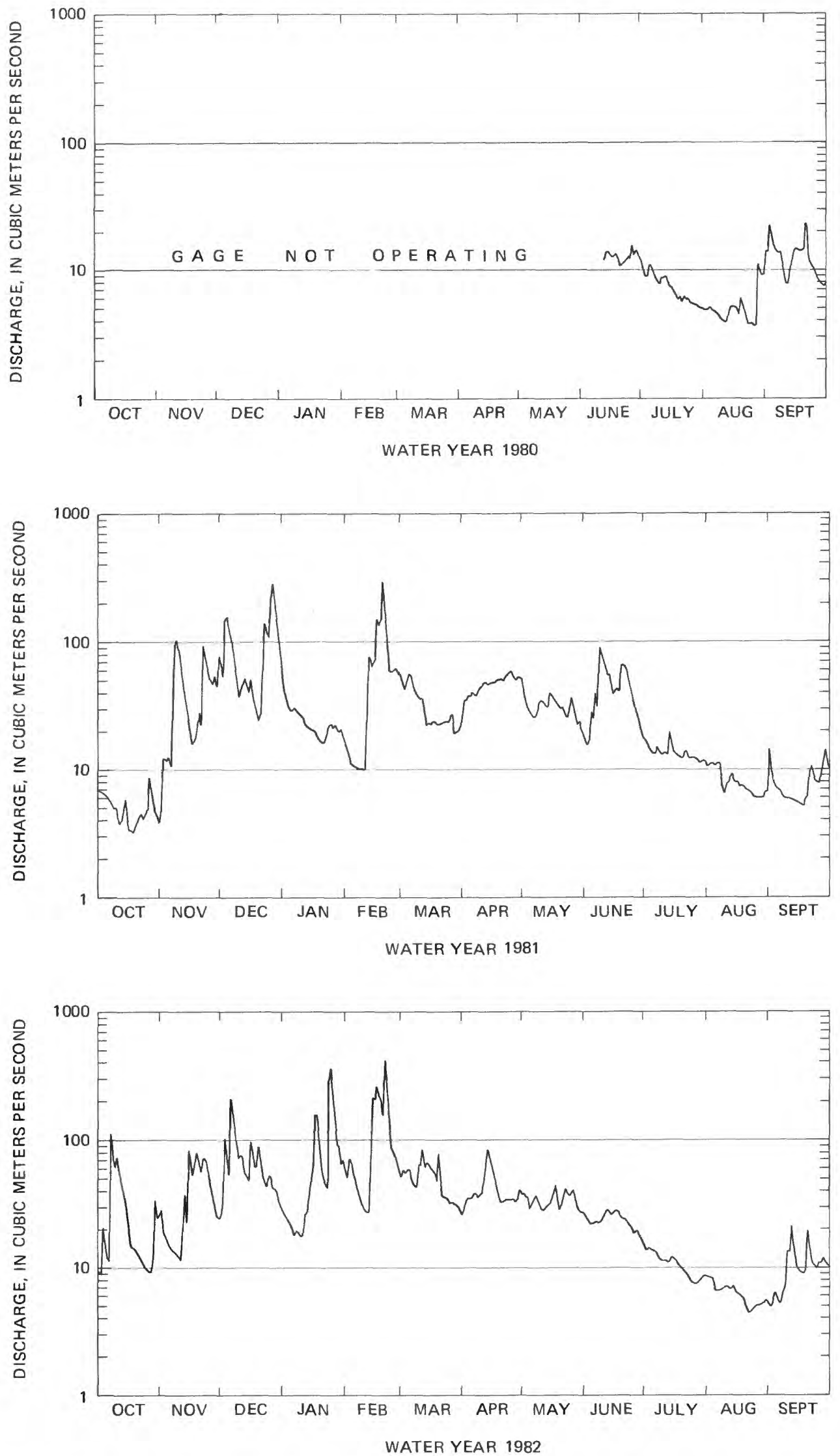

Figure 9. - Annual hydrograph of daily mean discharge for North Fork Toutle River at Kid Valley, Washington, water years 1980-82. 


\section{METHODS OF DATA COLLECTION}

\section{Cross-Section Location}

Cross sections were initially monumented and surveyed during the summer and fall of 1980 along the North Fork Toutle, South Fork Toutle, Green, and Toutle Rivers (figs. 2-6). Cross-section sites were selected using several criteria. Within the Toutle River drainage basin, many cross sections were located at bridge sites or other locations where pre-eruption survey data are available. One or more cross sections are usually located at or near gaging stations. Many cross sections were located to coincide with cross sections measured photogrammetrically (from imagery taken during June and July 1980). Where either pre-eruption or photogrammetric cross section locations were reoccupied, or where cross sections were located at gaging stations, additional sections were added to form clusters of cross sections with a spacing of two to three sections per kilometer. Clusters of sections were used to monitor changes in pattern and slope (as well as cross-section shape) within specific reaches, and to sample different environments within the reaches. Thirty clusters, including 120 cross sections, are included in this report (table 3 ). The North Fork Toutle River drainage dominates the Toutle basin in terms of size, degree of volcanic impact, and runoff production (table 1). Therefore, 48 percent of the channel cross sections and 58 percent of the individual surveys presented in this report are from the North Fork Toutle basin.

The network of cross-section measurement sites established during the summer and fall of 1980 was subsequently expanded. Cross sections have been added to as channels shifted, new channels and alluvial fans formed, or conditions developed that required more detailed measurements. Along the so-called Bear Creek and Lower Avalanche reaches of the North Fork Toutle River (table 3 and fig. 3), accelerated bank erosion has been so extensive that all monuments for some cross sections were destroyed. When this occurred, new cross sections were monumented close to the same location, but relocation of cross sections is only approximate, with questionable elevation control. These sections are plotted separately, one survey to a plot, in order to avoid potentially spurious comparisons.

The entire network of cross sections is surveyed annually at the end of the rainy season. A subset of 22 cross sections is surveyed more frequently, following significant winter storm flow and volcanic events (table 3). 
TABLE 3.--Description of cross section network in the Toutle River basin, 1980-1982, Mount St. Helens

\begin{tabular}{llccc}
\hline $\begin{array}{c}\text { Drainage basin } \\
\text { subbasin }\end{array}$ & Reach name & $\begin{array}{c}\text { Total number of } \\
\text { cross sections }\end{array}$ & $\begin{array}{c}\text { Number of cross } \\
\text { section surveyed } \\
\text { after storms }\end{array}$ & $\begin{array}{c}\text { Numbering } \\
\text { sequence }\end{array}$ \\
\hline Green River & Grizzly Creek & 5 & & \\
& Polar Star Mine & 2 & 0 & GR850-GR870 \\
& Shultz Creek & 4 & 0 & GR880-GR890 \\
& Hatchery & 6 & 0 & GR900-GR915
\end{tabular}

North Fork

Toutle River

Loowit

Crater

2

3

1

4

1

Maratta Creek

North Fork Toutle

\section{Coldwater \\ 1}

E1k Rock

Bear Creek

Lower Avalanche

$\mathrm{N}-1$

Camp Baker

Salmon Reach A

Kid Valley

Salmon Reach B

Salmon Reach C
3

5

3

2

8

3

3

5

4

South Fork

Toutle River

Disappointment

Spotted Buck

Above S-1

Mouth
0

0

1

1

0

1

1

2

1

1

1

1

1

0

2

1
L0010-L0020

L0030-L0040

TR065

CS075-CS085

CW250-CW280

MR290

NF 130

NF310-NF325

NF330-NF350

NF365-NF375

NF390-NF395

NF410-NF445

NF465-NF475

NF500-NF515

NF535-NF590

NF575-NF590

Toutle River Mainstem

Coal Bank Bridge

Spool

Tower Bridge

Burma Gorge

Highway 99
1
SF675

SF685-SF715

SF730-SF750

SF760-SF810 
Cross sections usually span the valley floor, and are located by establishing a line of sight perpendicular to the channel, or perpendicular to the valley floor where the channel is braided. Because of severe channel shifts, cross sections may not remain perpendicular to the channe1. Endpoints are monumented with metal fenceposts or sections of steel rebar. Channel cross sections are usually surveyed using electronic distance measuring (EDM) equipment and a theodolite. The instruments are set up on line with the monuments, which serve as reference marks for horizontal and vertical control. Deep gullies or vertical banks occasionally preclude precise surveying measurements within the available time, and a few points on the cross section are measured with hand level and tape. In cases where the channels cannot be waded on line with the cross section, estimates of maximum depth of the channel are made. During high flows of winter and spring, channels along much of the Toutle River and the lower North Fork Toutle River are surveyed using an airboat. The above-water portions of the cross section and portions of the section that can be waded are surveyed as described above. Measurements of horizontal distance to the boat from reference monuments are made using either an EDM or a tagline. Depths are sounded manually from the boat. Cross sections that are located at bridges are often measured by sounding from the bridge. Commonly, this entails use of a bridgeboard, A-reel, and $34-$ or $45-\mathrm{kg}$ sounding weights.

Field data are entered into a computer, converted to relative horizontal distance and elevation, and referenced to monuments with fixed station distance and elevation. Elevation is either arbitrary or tied to the National Geodetic Vertical Datum of 1929. Surveys are plotted using digital plotters and are superimposed on earlier surveys of the same cross section.

Accuracy and precision of surveys are dependent on the nature of the channe1, on weather at the time of the survey, and on surveying techniques. Surveys of wide channels are not as precise as surveys of narrow channels. Selection of surveyed points introduces a large degree of uncertainty in reproducing rough surfaces that have not changed. Inadequate visibility and atmospheric temperature and pressure fluctuations affect the accuracy of EDM measurements, and wind and saturated ground occasionally cause difficulties in precise leveling. When at least two monuments remain from previous surveys to establish the cross section bearing, and points that are common to previous surveys are measured consistantly, both horizontal and vertical precision are generally within $0.05 \mathrm{~m}$, regardless of adverse weather conditions.

Channel cross-section profiles constructed from the survey data coilected during water years 1980 through 1982 are presented in figures 15 through 215, at the end of the report. 


\section{REFERENCES}

Brugman, M. M., and Post, Austin, 1980, Effects of volcanism on the glaciers of Mount St. Helens: U.S. Geological Survey Circular 850-D, $11 \mathrm{p}$.

Collins, B., Dunne, T., and Lehre, A. K., 1981, Sediment influx to the Toutle River from erosion of tephra, May 1980-May 1981: Proceedings from the Conference Mount St. Helens: Effects on Water Resources, Jantzen Beach, Oregon, Oct. 7-8, 1981, p. 82-97.

Cummans, John, 1981, Chronology of mudflows in the South Fork and North Fork Toutle River following the May 18, eruption: U.S. Geological Survey Professional Paper 1250, p. 479-486.

Hobblitt, R. P., Miller, C. D., and Vallance, J. W., 1981, Origin and stratigraphy of the deposit produced by the May 18 directed blast: U.S. Geological Survey Professional Paper 1250, p. 401-420.

Janda, R. J., Scott, K. M., Nolan, K. M., and Martinson, H. A., 1981, Lahar movement, effects, and deposits: U.S. Geological Survey Professional Paper 1250, p. 601-616.

Lehre, A. K., Collins, B., and Dunne, T., 1981, Preliminary post-eruption sediment budget for the North Fork Toutle River drainage, June 1980-May 1981: Proceedings from the Conference Mount St. Helens: Effects on Water Resources, Jantzen Beach, Oregon, Oct. 7-8, 1981, p. 215-234.

Lisle, T. E., Lehre, A. K., Martinson, H. A., Meyer, D. F., Nolan, K. M., and Smith, R., 1983, St ream channel adjustments after the 1980 Mount St. Helens eruptions: in Proceedings of the Symposium on Erosion Control in Volcanic Areas, July 6-9, 1982, Seattle and Vancouver, Washington, Technical Memorandum of PWRI No. 1908, p. 31-72.

Martinson, H. A., and Meyer, D. F., 1985, Stream channel adjustments to 1980 lahars and subsequent stormflow, Mount St. Helens: (abst.) in Glysson, G. D., ed., U. S. Geological Survey Open-File Report 85-98, Proceedings of the Advanced Seminar on Sedimentation, Aug. 15-19, 1983, Denver, Colorado, p. 31-33.

Meyer, D. F., and Janda, R. J., 1985, Erosional development of the North Fork Toutle debris avalanche deposit: (abst.) in Glysson, G. D., ed., U. S. Geological Survey Open-File Report 85-98, Proceedings of the Advanced Seminar on Sedimentation, Aug. 15-19, 1983, Denver, Colorado, p. 34-36.

Moore, J. G., and Sisson, T. W., 1981, Deposits and effects of the May 18 pyroclastic surge: U.S. Geological Survey Professional Paper 1250, p. 421-438.

Pacific Northwest River Basins Commission, 1970, Comprehensive framework study of water and related lands, Appendix 5, Volume 2, Water Resources: $1,022 \mathrm{p}$. 


\section{UNITED STATES \\ DEPARTMENT OF THE INTERIOR \\ GEOLOGICAL SURVEY}

POST-ERUPTION CHANGES IN CHANNEL GEOMETRY

OF STREAMS IN THE TOUTLE RIVER DRAINAGE BASIN, 1980-82, MOUNT ST. HELENS, WASHINGTON

By D. F. Meyer, K. M. Nolan, and J. E. Dodge

U.S. GEOLOGICAL SURVEY OPEN-FILE REPORT 85-412

Tacoma, Washington 1986 
Phillips, E. L., 1974, Climate: in Cal1, W. A., 1974, Soil survey of Cowlitz area, Washington: U.S. Department of Agriculture, Soil Conservation Service, in cooperation with Washington Agricultural Experiment Station, p. 108-110.

Pierson, Thomas, C., 1983, Flow behavior of two major lahars triggered by the May 18, 1980, eruption of Mount St. Helens, Washington; in Proceedings of the Symposium on Erosion Control in Volcanic Areas, July $6-9,1982$, Seattle and Vancouver, Washington, Technical Memorandum of PWRI No. 1908, p. 99-129.

Pruitt, J., Edgren, J., Hamner, B., Howes, S., Patterson, P., Steward, J., Swank, J., 1980, Mount St. Helens emergency watershed rehabilitation report: U.S. Department of Agriculture, Forest Service, Pacifc Northwest Region, Portland, Oregon, 107 p., 13 appendices.

Rowley, P. D., Kuntz, M. A., and Macleod, N. S., 1981, Pyroclastic-flow deposits: U.S. Geological Survey Professional Paper 1250, p. 489-512.

Stockton, Steve, 1983, Engineering responses to flood hazards created by the eruptions of Mount St. Helens: in Proceedings of the Symposium on Erosion Control in Volcanic Areas, Ju1y 6-9, 1982, Seattle and Vancouver, Washington, Technical Memorandum of PWRI No. 1908, p. 249-272.

Voight, Barry, Glicken, H. A., Janda, R. J., and Douglass, P. M., 1981, Catastrophic rockslide avalanche of May 18: U.S. Geological Survey Professional Paper 1250 , p. 601-616.

Waitt, R. B., Jr., and Dzurisin, D., 1981, Proximal air-fall deposits from the May 18 eruption - stratigraphy and field sedimentology: U.S. Geological Survey Professional Paper 1250, p. 601-616.

Waitt, R. B., Jr., Hansen, U. L., Sarna-Wojcicki, A. M., and Wood, S. H., 1981, Proximal air-fall deposits of eruptions between May 24 and August 7, 1980 - stratigraphy and field sedimentology: U.S. Geological Survey Professional Paper 1250, p. 617-630.

Waitt, R. B., Jr., Pierson, T. C., MacLeod, N. S., Janda, R. J., Voight, Barry, and Holcomb, R. T., 1983: Eruption-triggered avalanche, flood, and lahar at Mount St. Helens-effects of winter snowpack: Science, v. 221 , p. 1394-1397. 


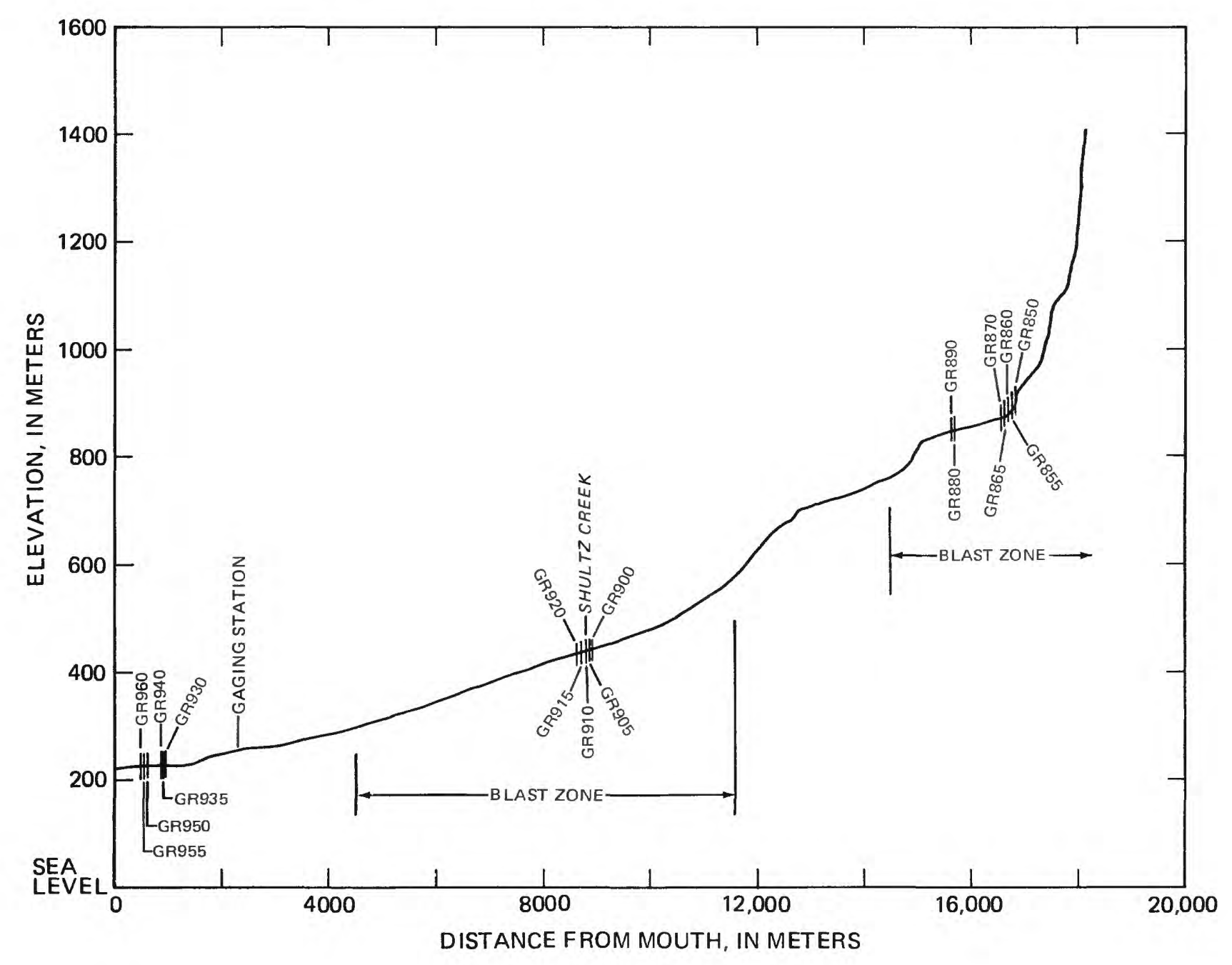

Figure 10.--Longitudinal profile of Green River, showing locations of cross sections. 

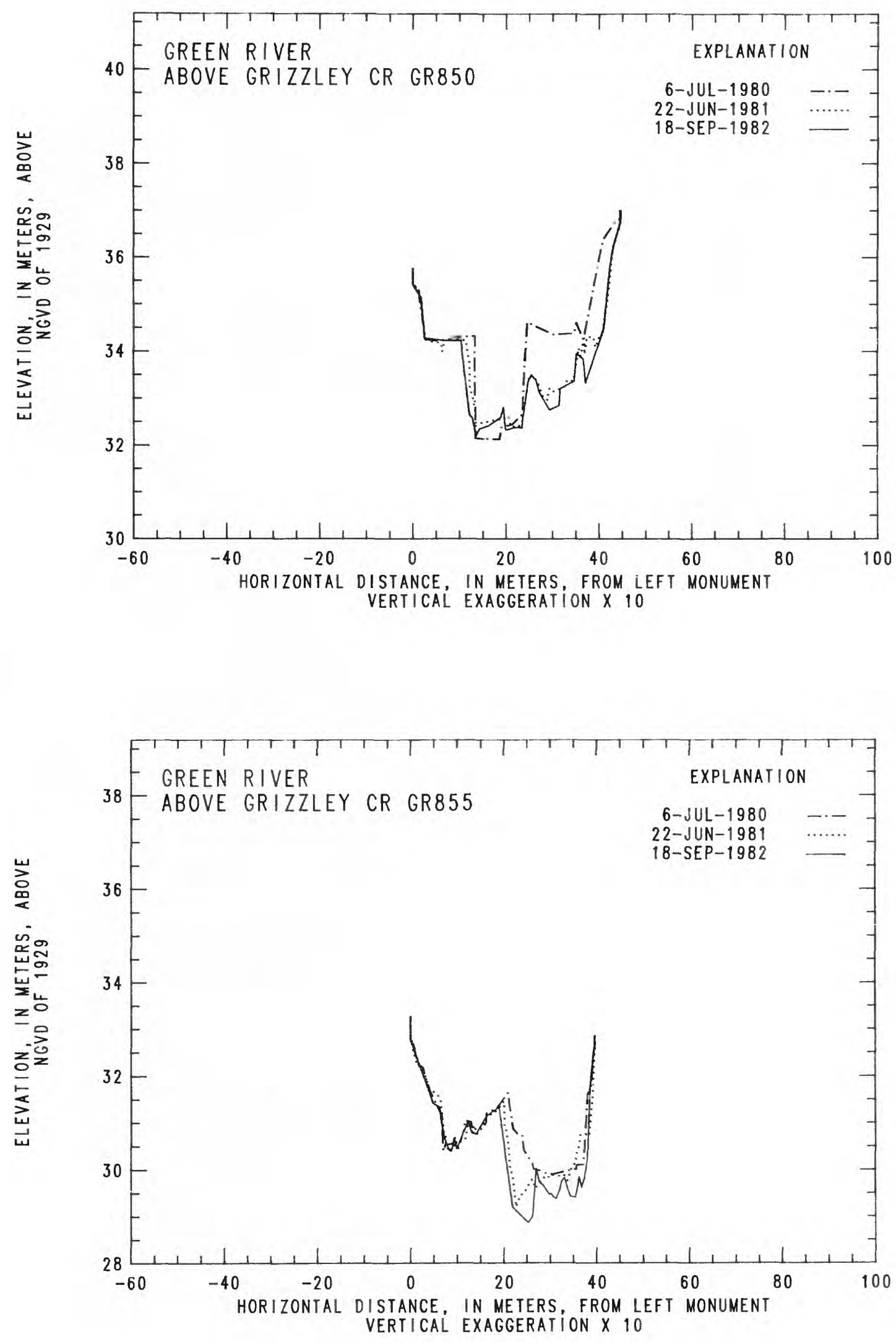

Figure 11.--Channel cross-section profiles for selected sites, Green River 

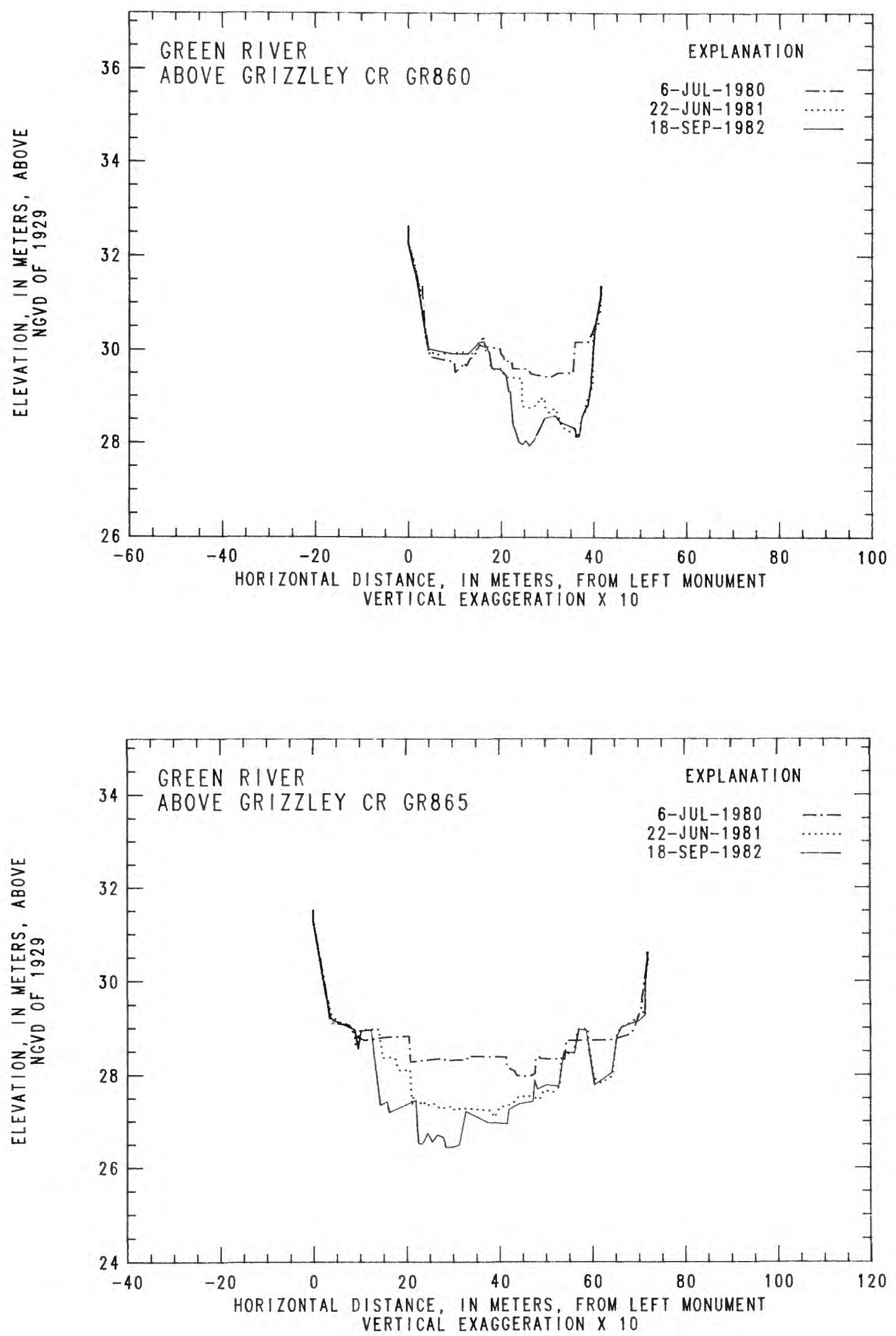

Figure 11.--Channel cross-section profiles for selected sites, Green River--Continued 

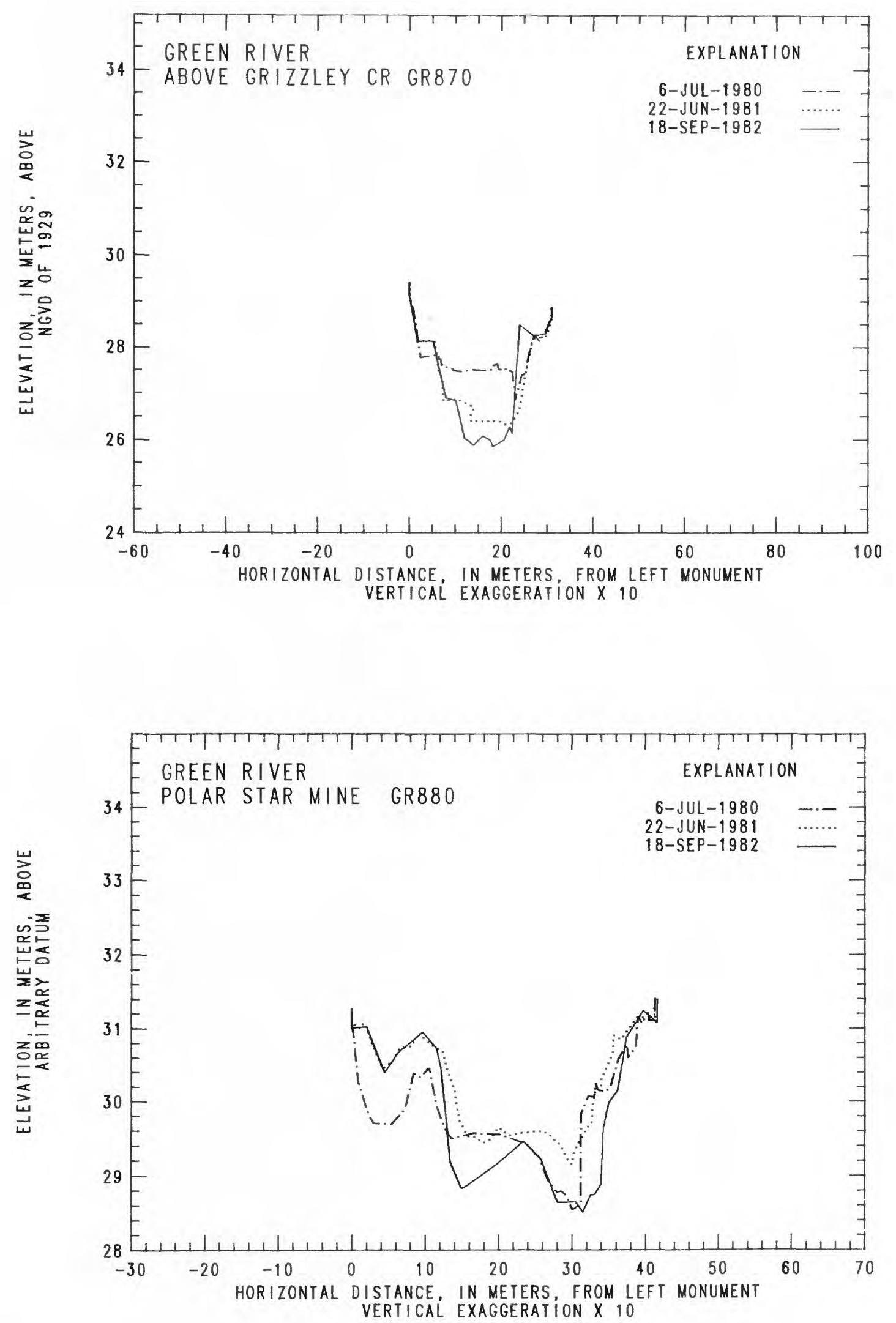

Figure 11.--Channel cross-section profiles for selected sites, Green River--Continued 

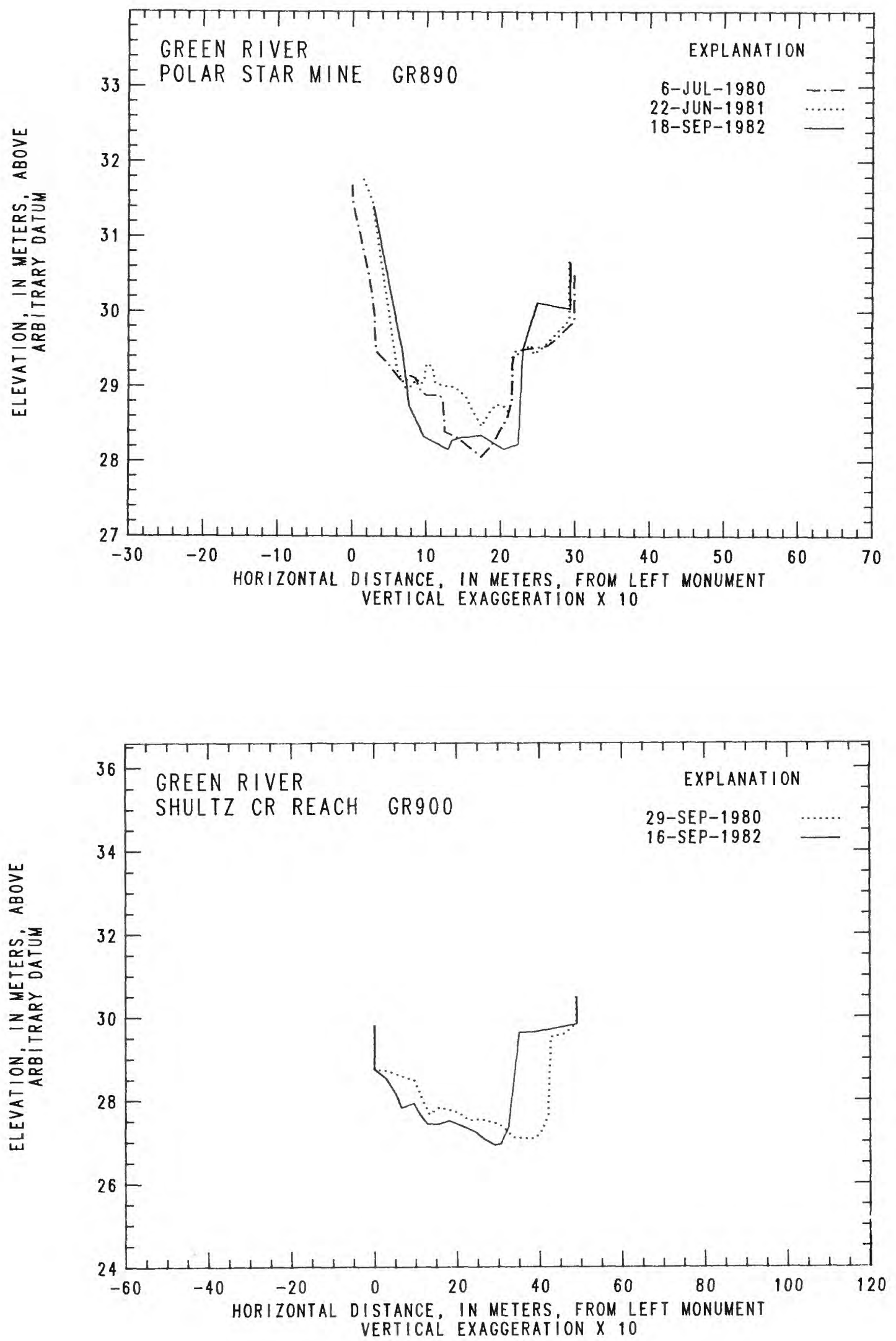

Figure 11.--Channel cross-section profiles for selected sites, Green River--Continued 

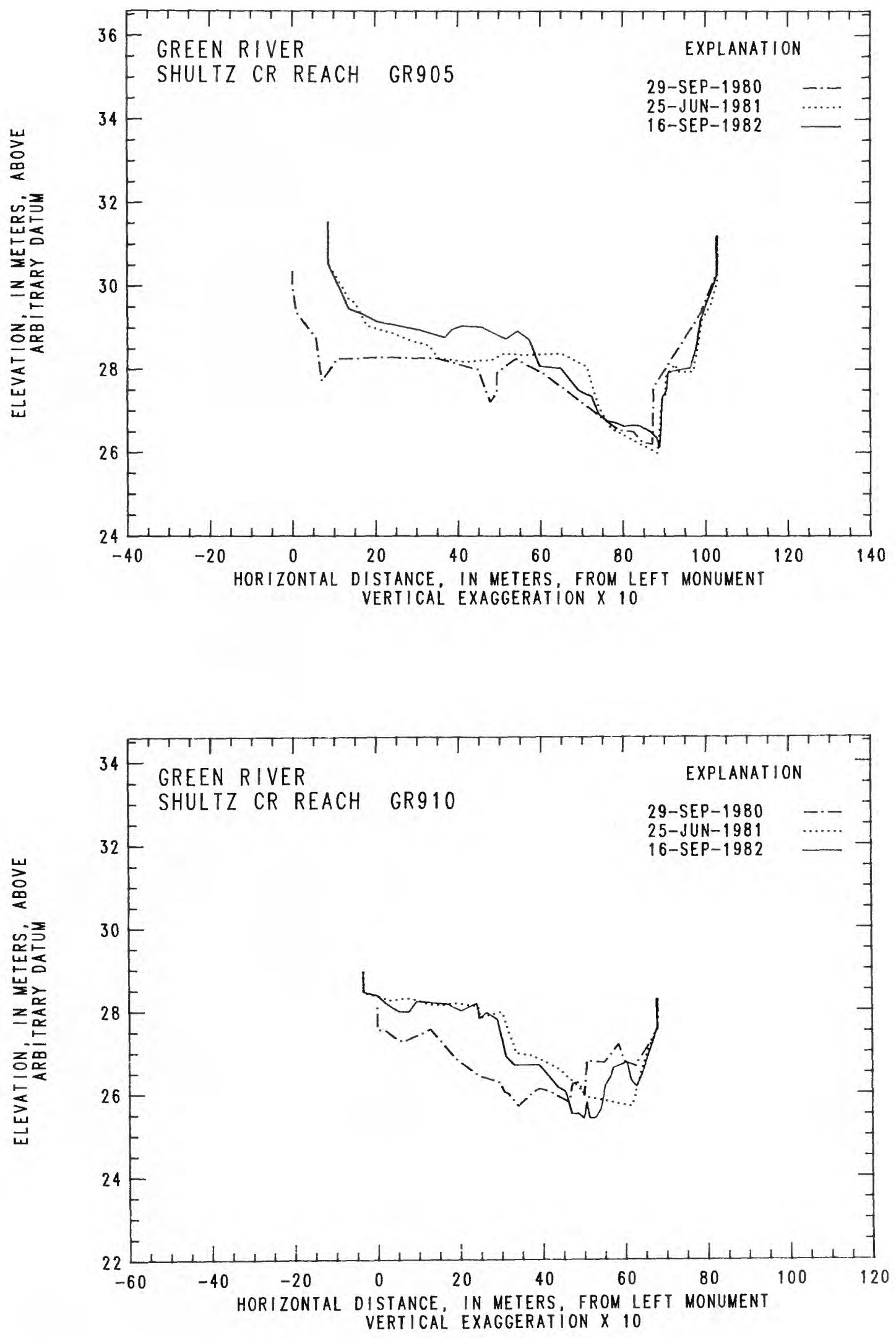

Figure 11.--Channel cross-section profiles for selected sites, Green River--Continued 

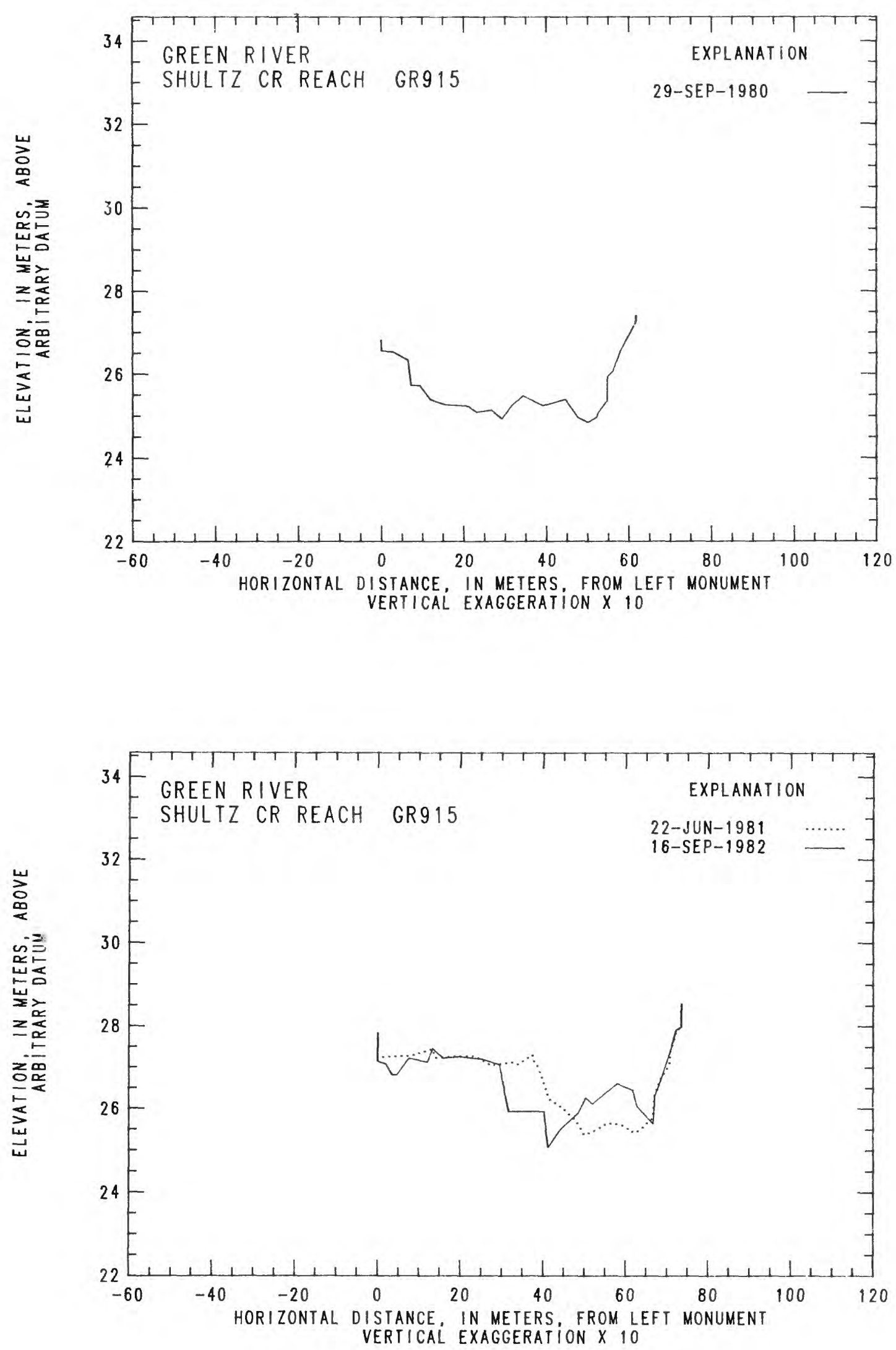

Figure 11.--Channel cross-section profiles for selected sites, Green River--Continued 

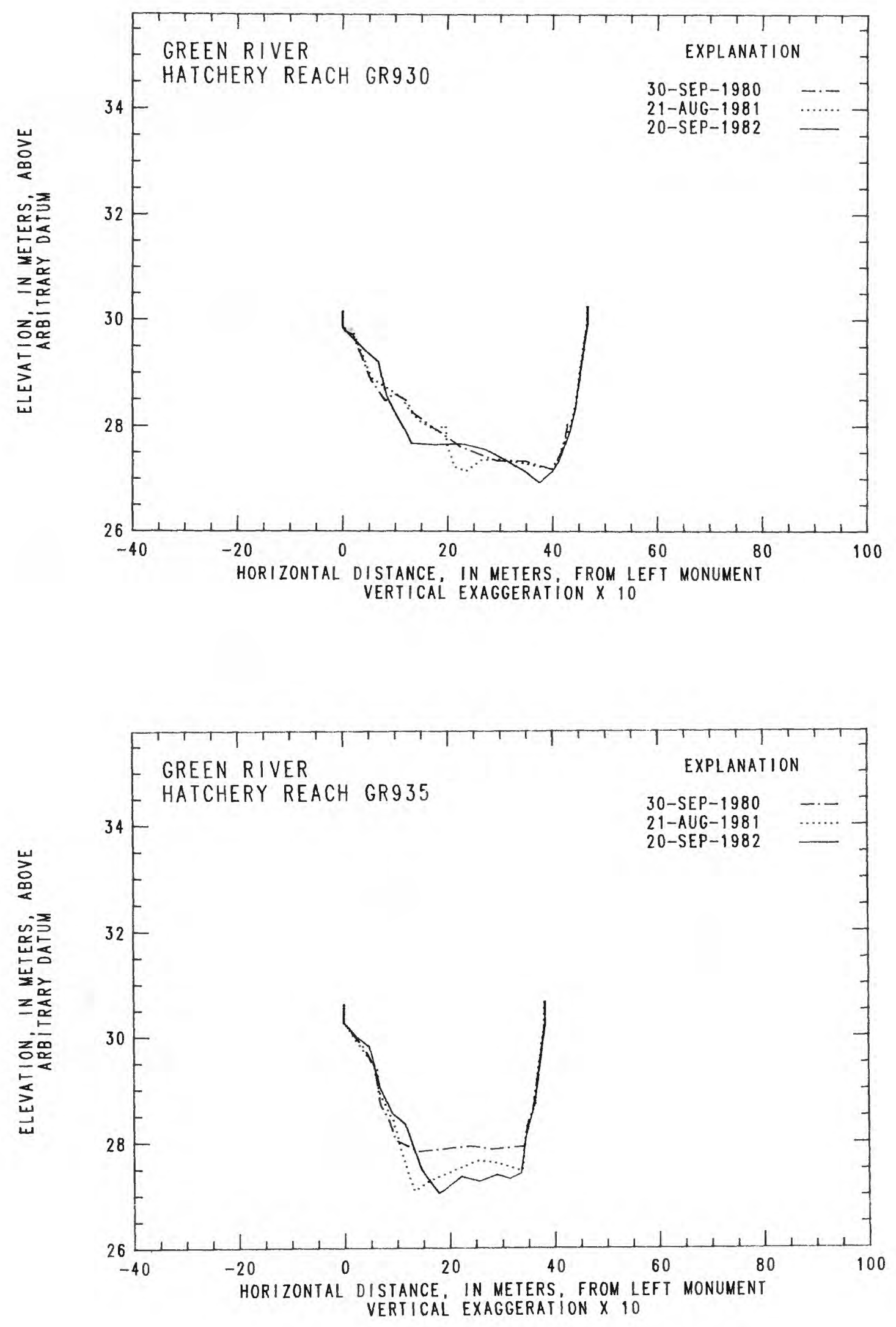

Figure 11.--Channel cross-section profiles for selected sites, Green River--Continued 

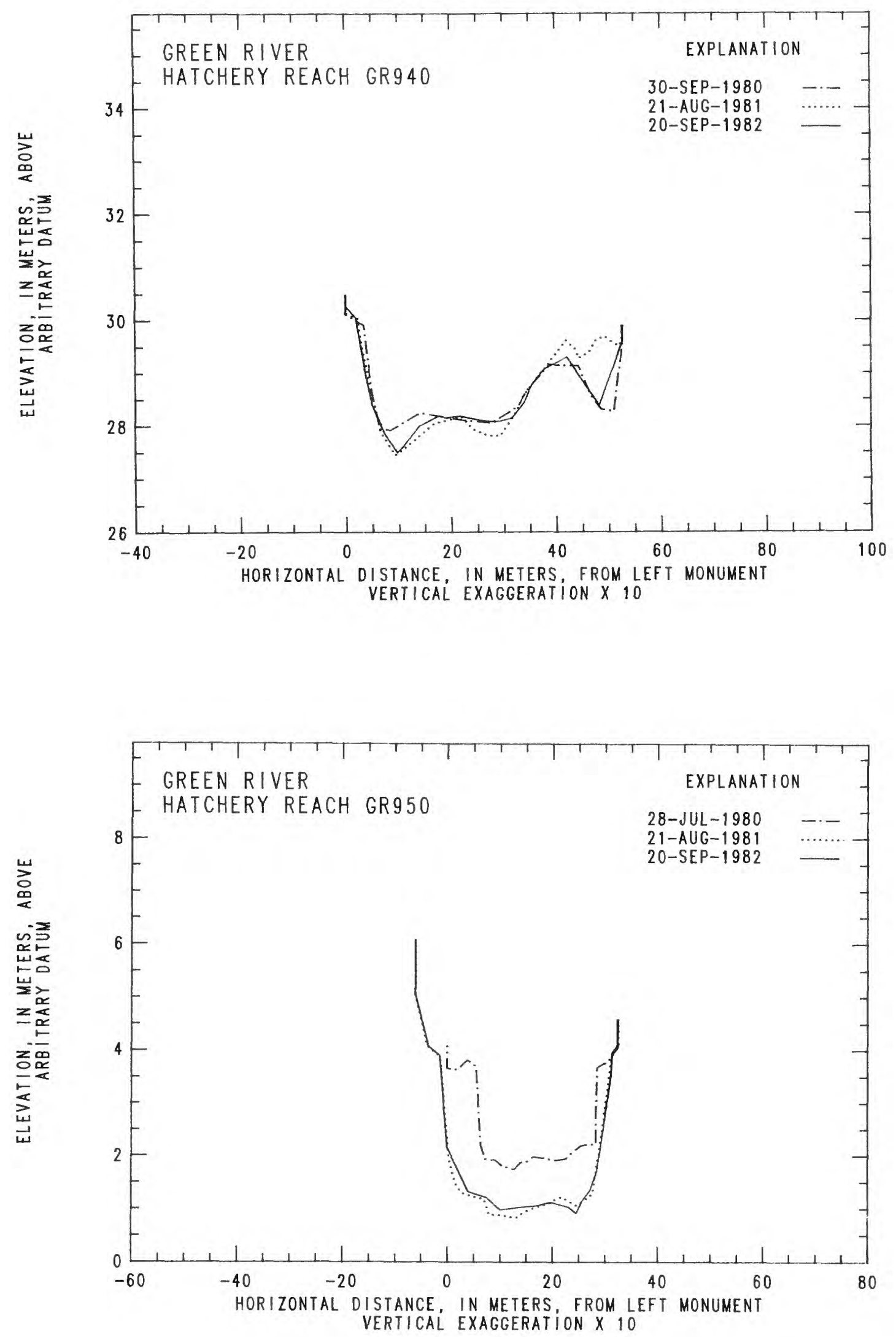

Figure 11.--Channel cross-section profiles for selected sites, Green River--Continued 


\author{
UNITED STATES DEPARTMENT OF THE INTERIOR \\ Donald P. Hode1, Secretary \\ GEOLOGICAL SURVEY \\ Dallas L. Peck, Director
}

For additional information write to:

District Chief

U.S. Geological Survey

1201 Pacific Avenue - Suite 600

Tacoma, Washington 98402-4384
Copies of this report can be purchased from:

Open-File Services Section Western Distribution Branch U.S. Geological Survey Box 25425, Federal Center Lakewood, Colorado 80225 (Telephone: (303) 234-5888) 


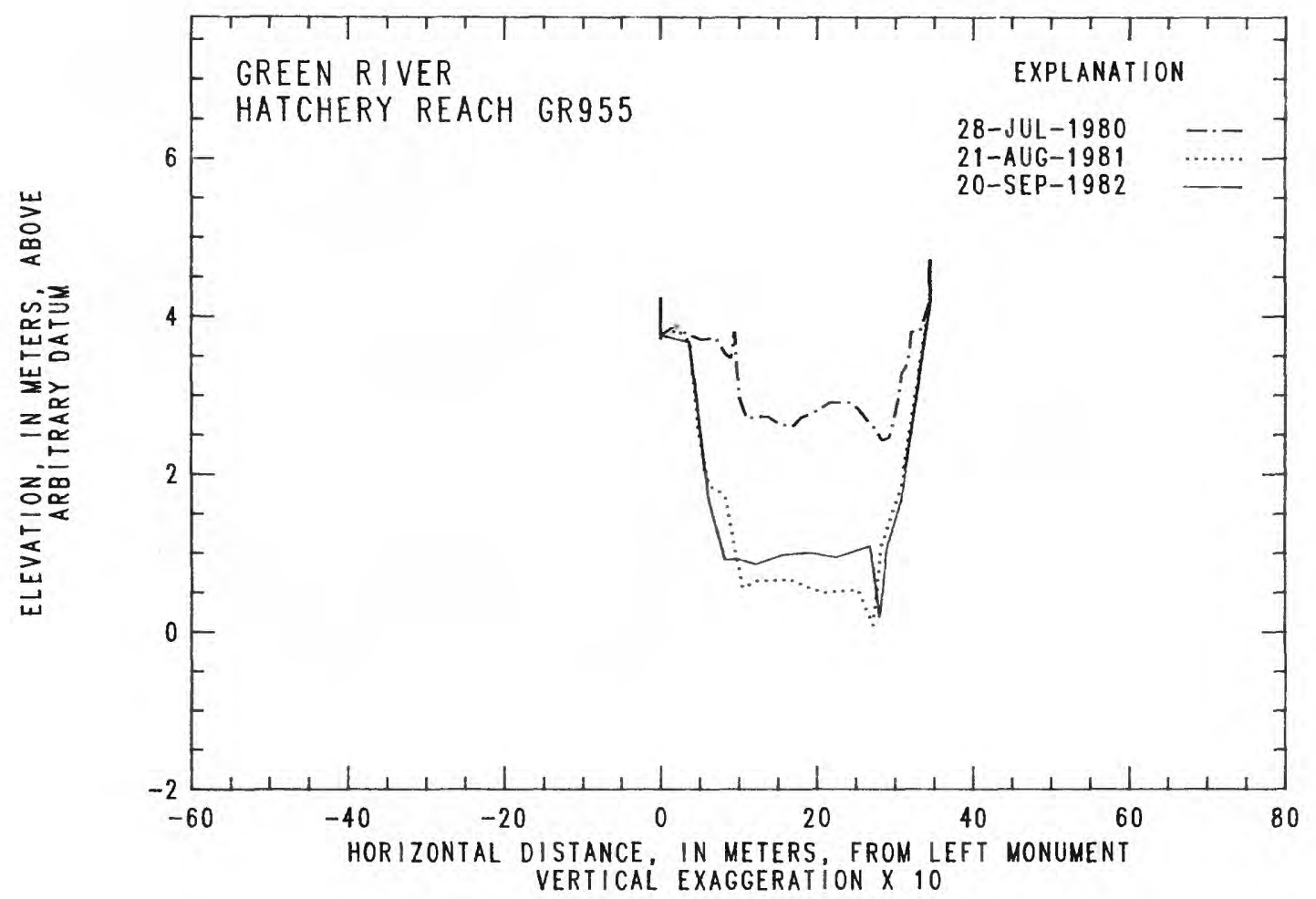

Figure 11.--Channel cross-section profiles for selected sites, Green River--Continued 

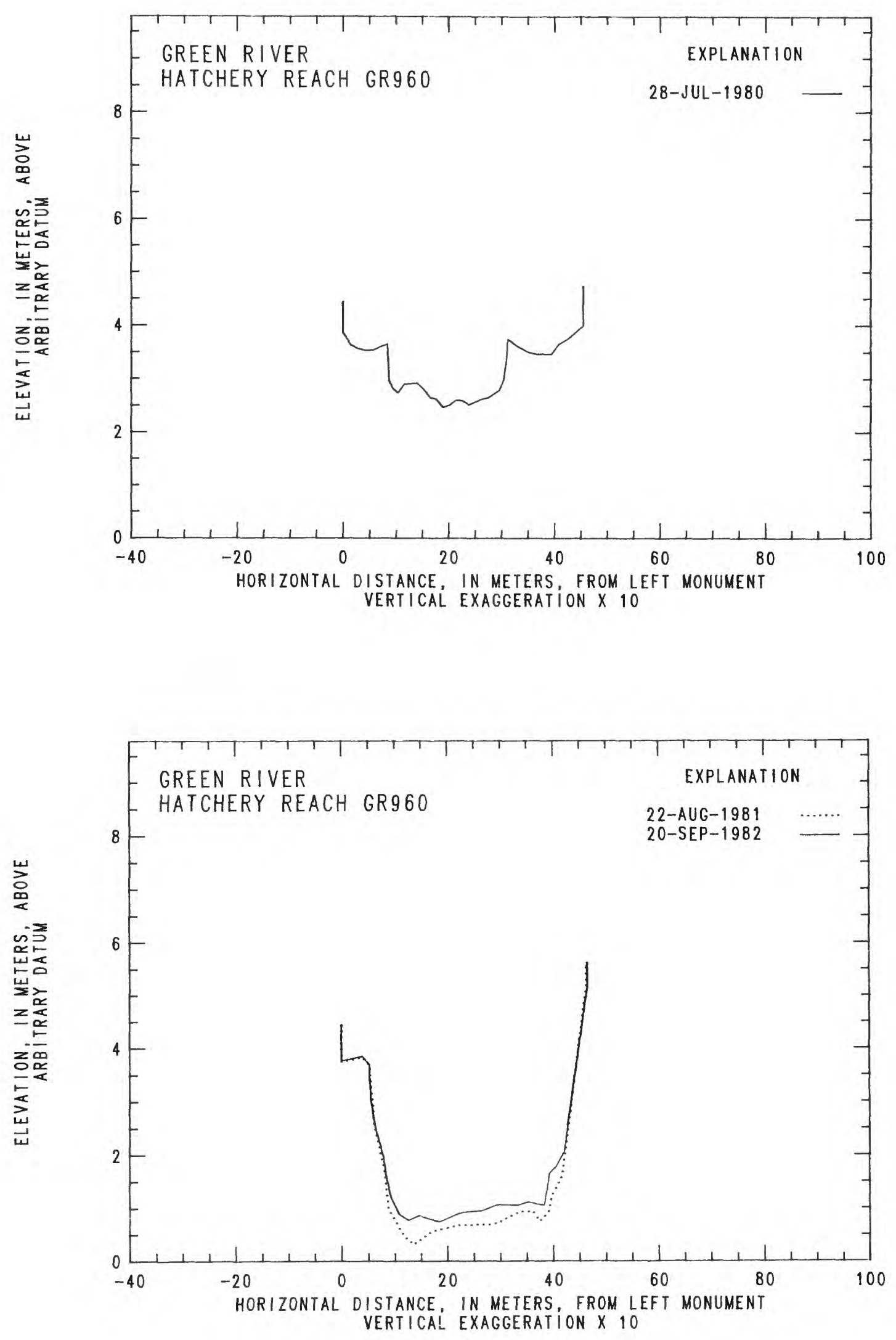

Figure 11.--Channel cross-section profiles for selected sites, Green River--Continued 


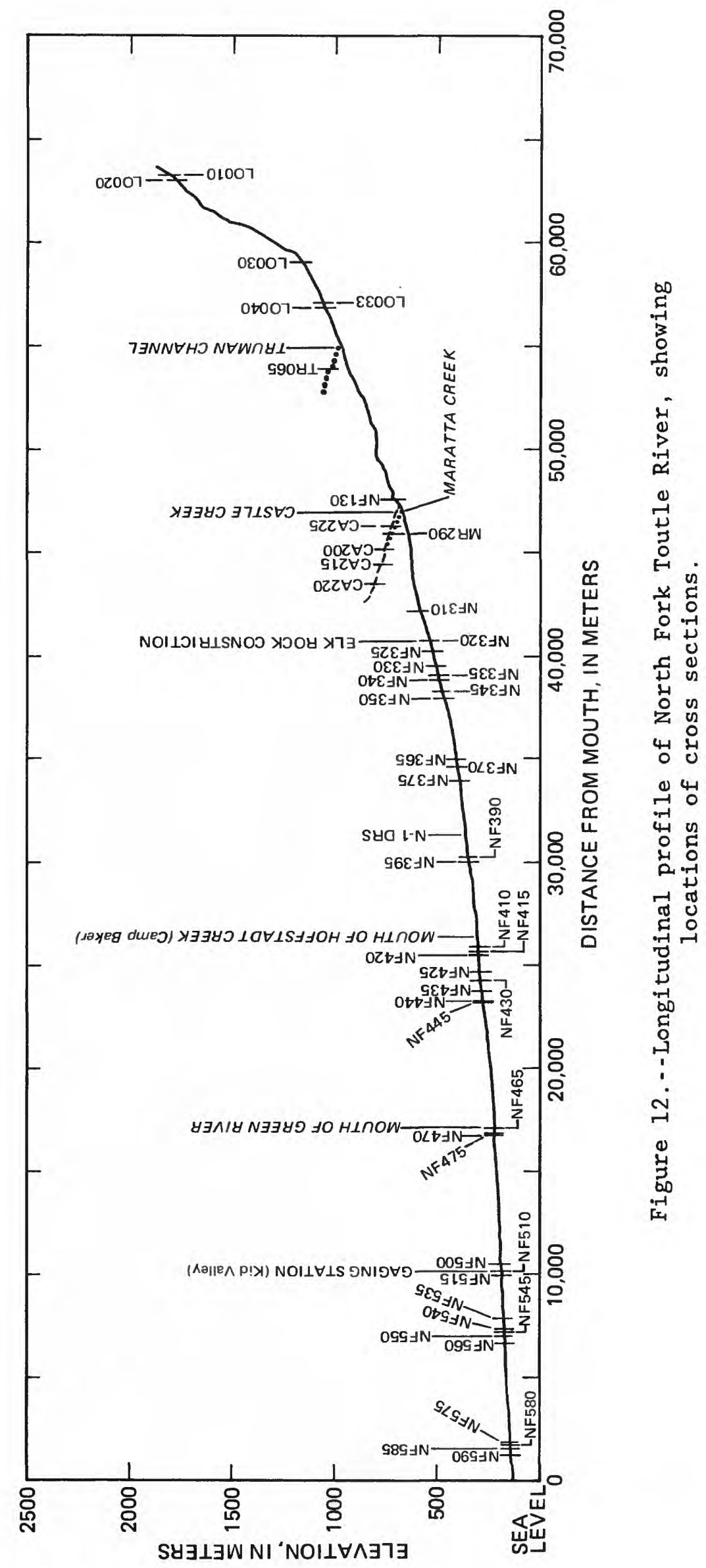



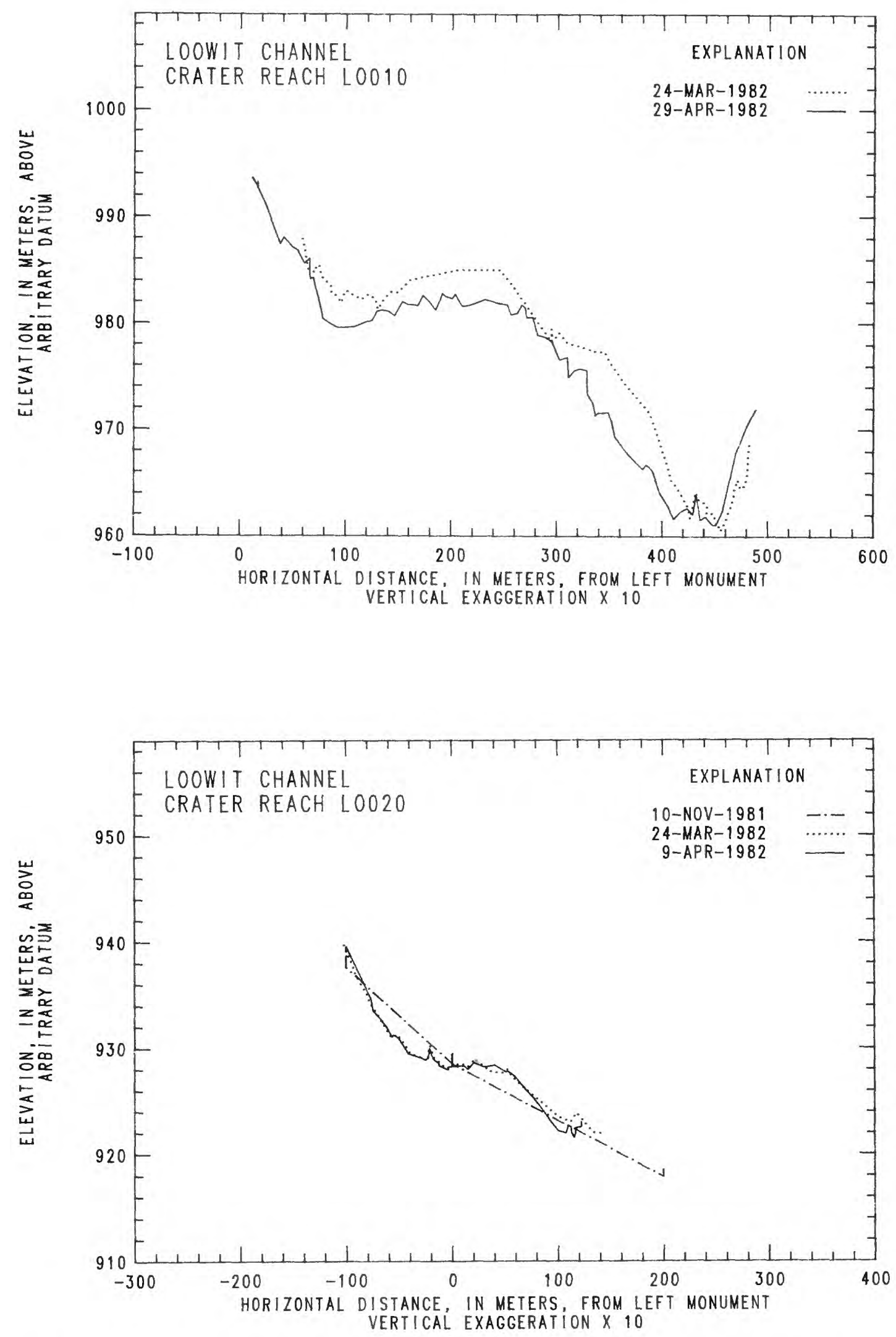

Figure 13.--Channel cross-section profiles for selected sites, North Fork Toutle River 

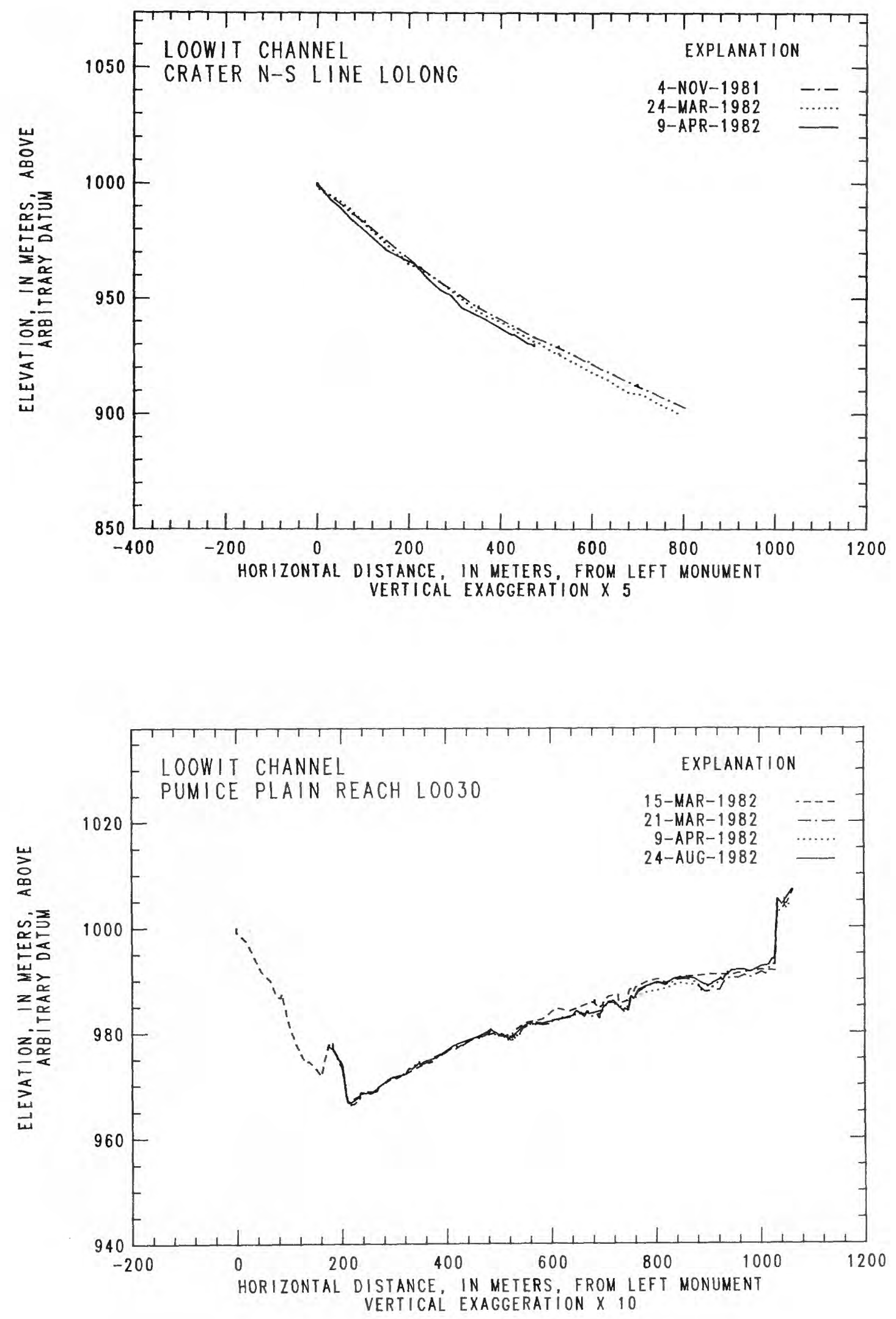

Figure 13.--Channel cross-section profiles for selected sites, North Fork Toutle River--Continued 

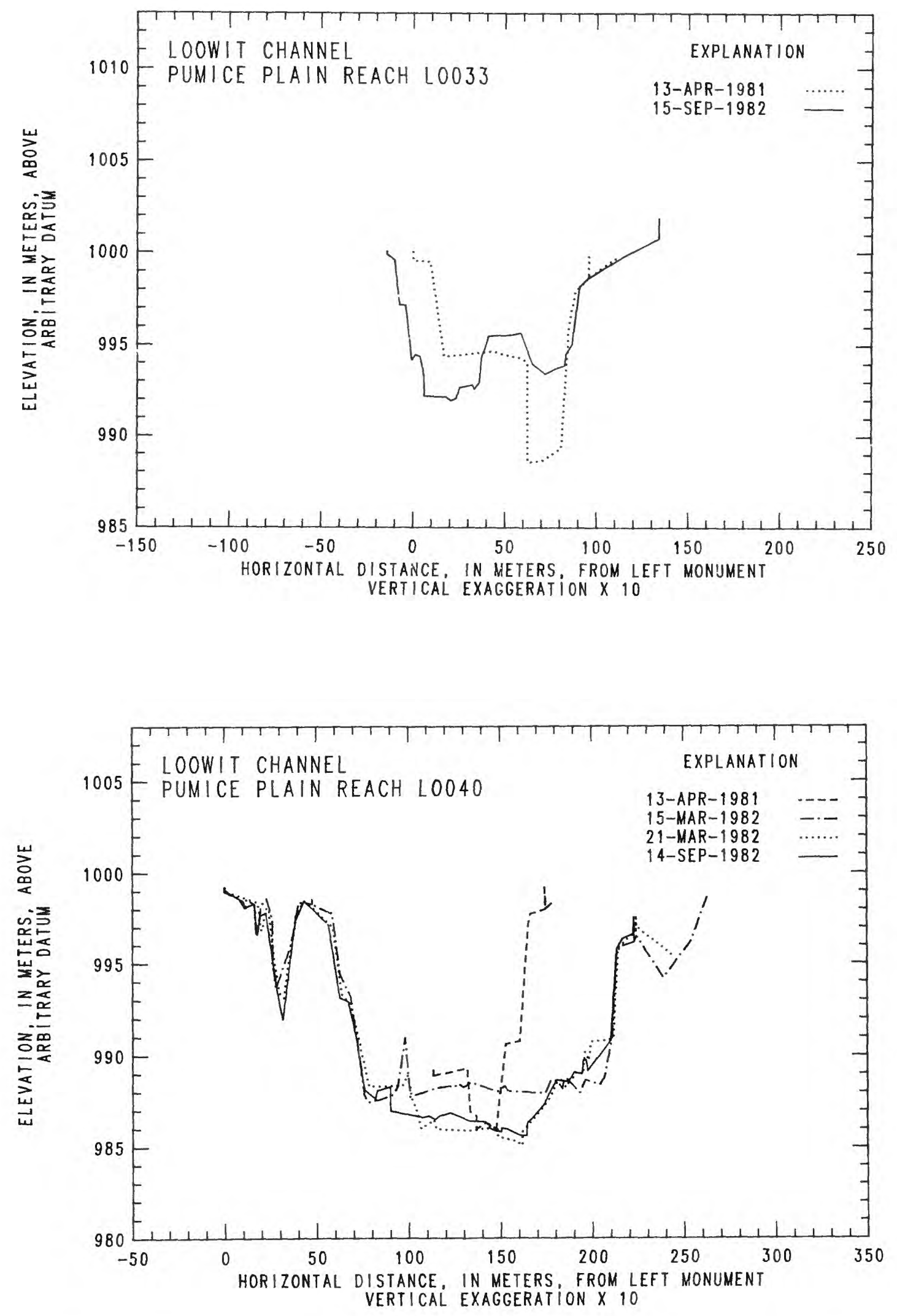

Figure 13.--Channel cross-section profiles for selected sites, North Fork Toutle River--Continued 

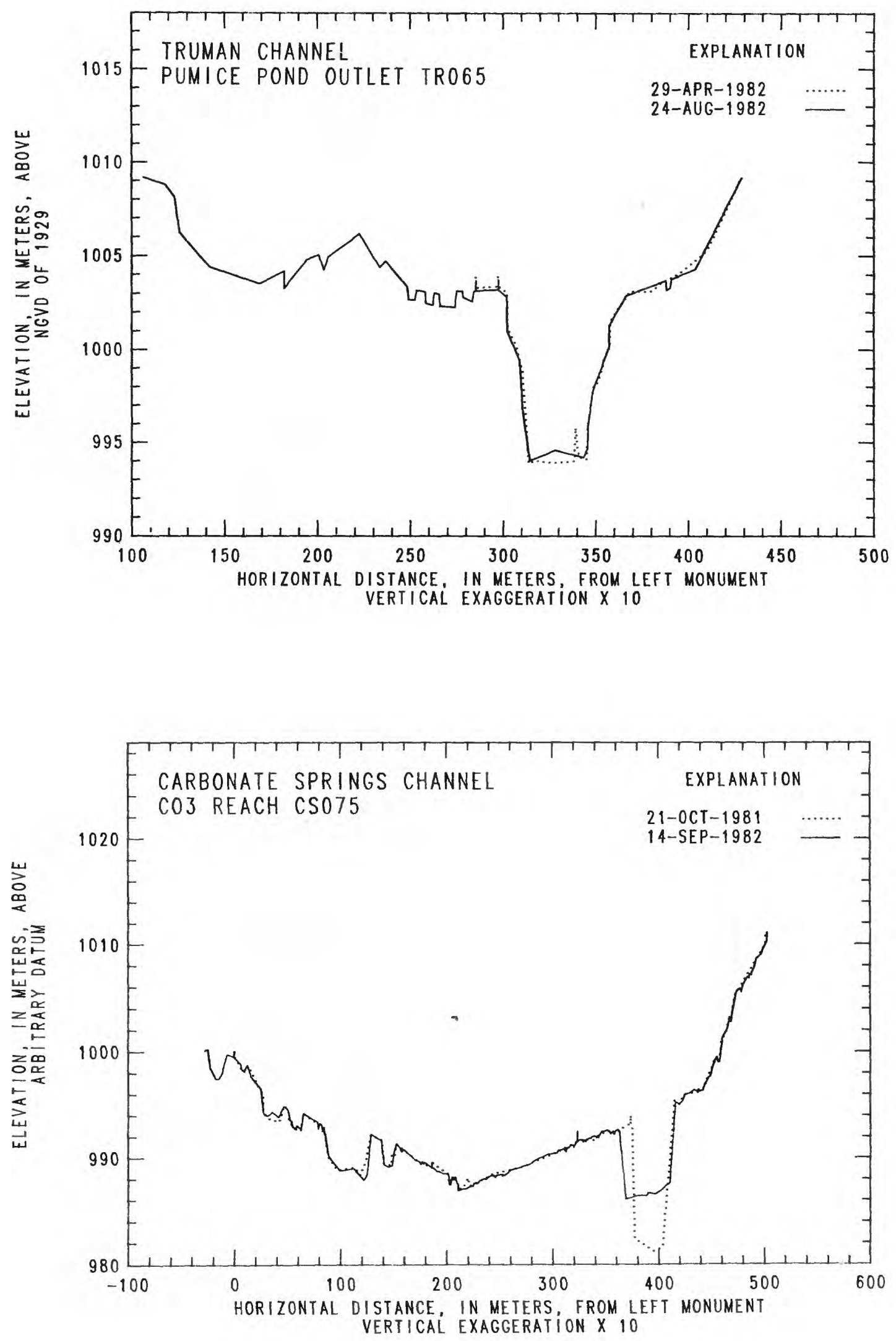

Figure 13.--Channe1 cross-section profiles for selected sites, North Fork Toutle River--Continued 

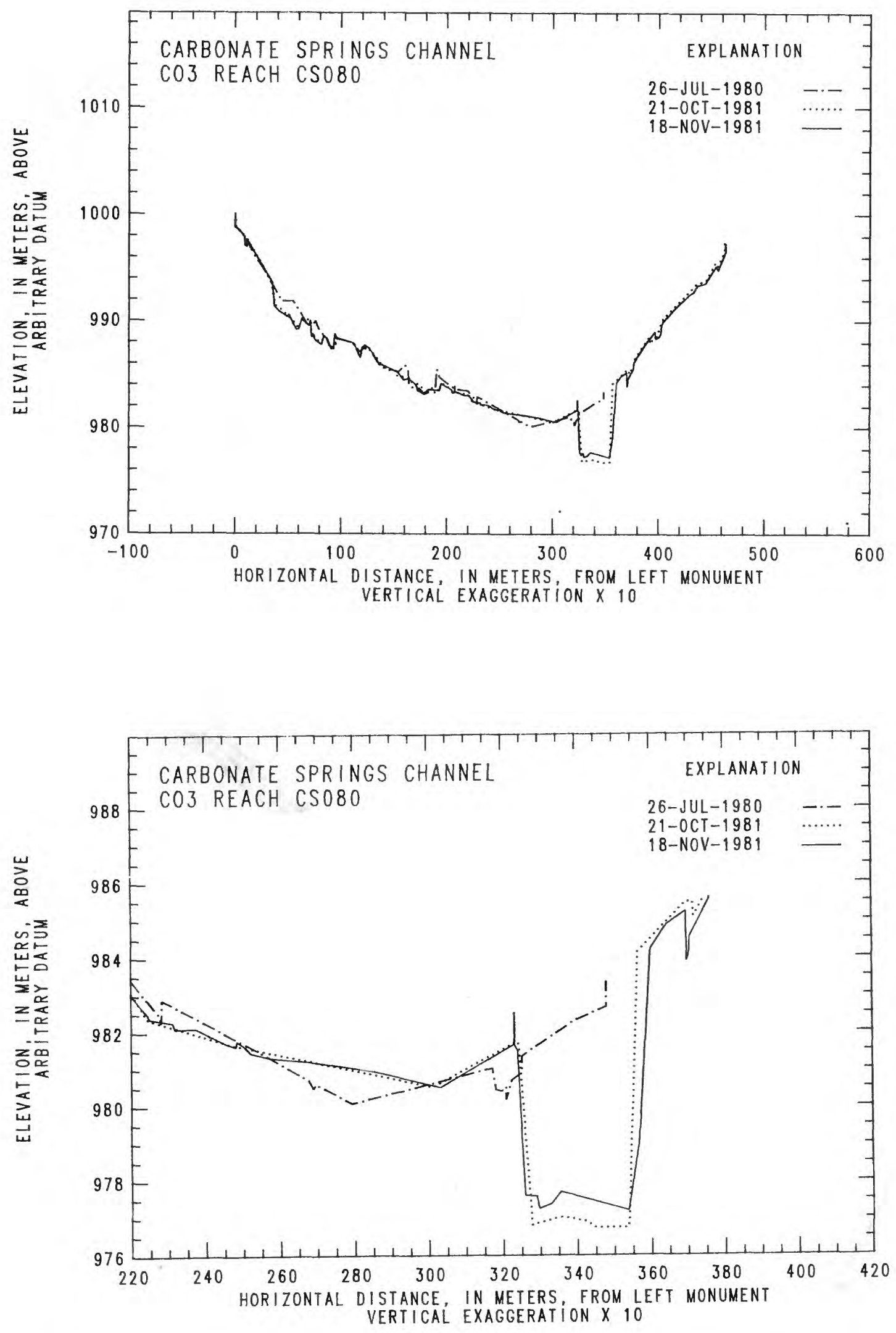

Figure 13.--Channel cross-section profiles for selected sites, North Fork Toutle River--Continued 

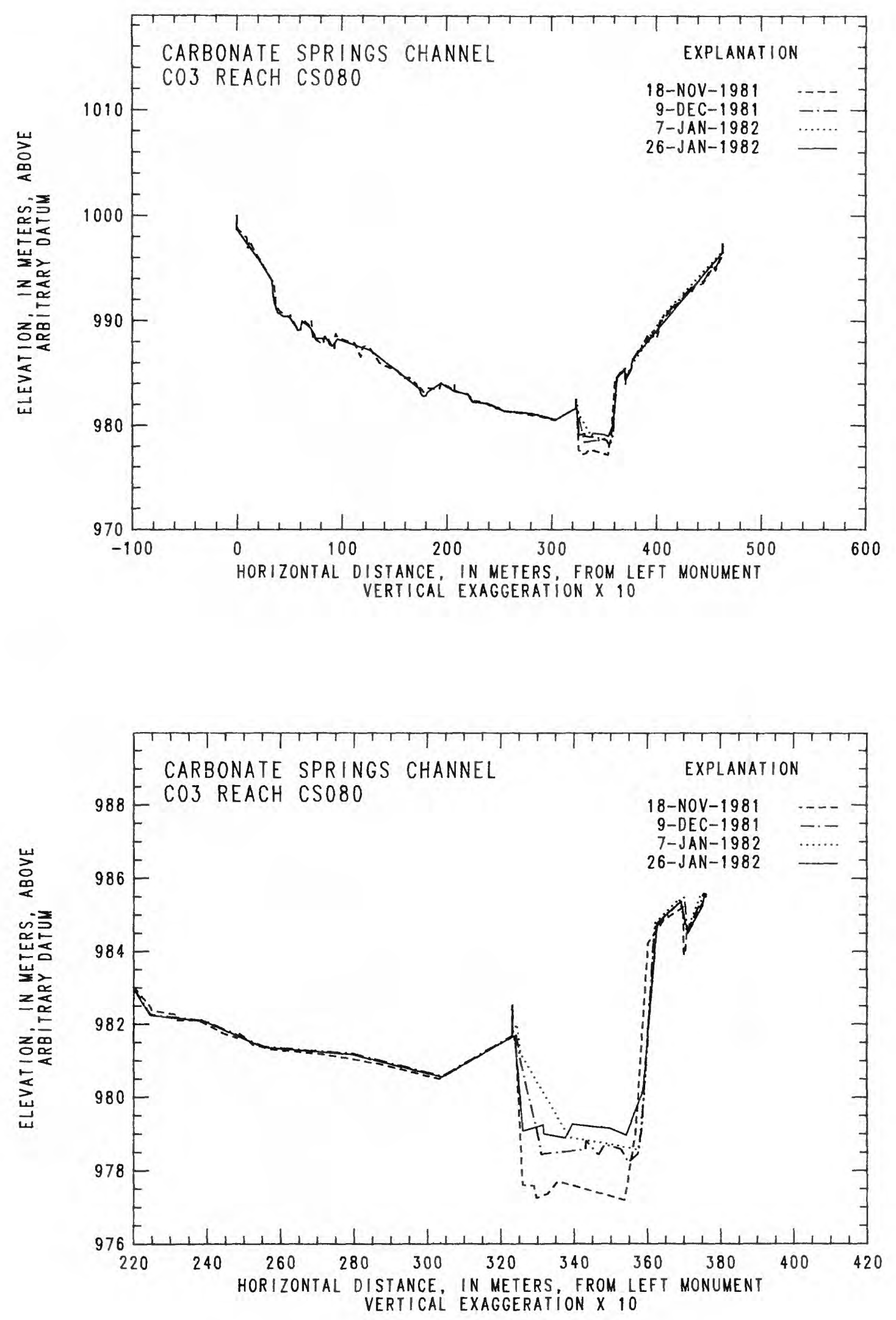

Figure 13 - Channel cross-section profiles for selected sites, North Fork Toutle River--Continued 

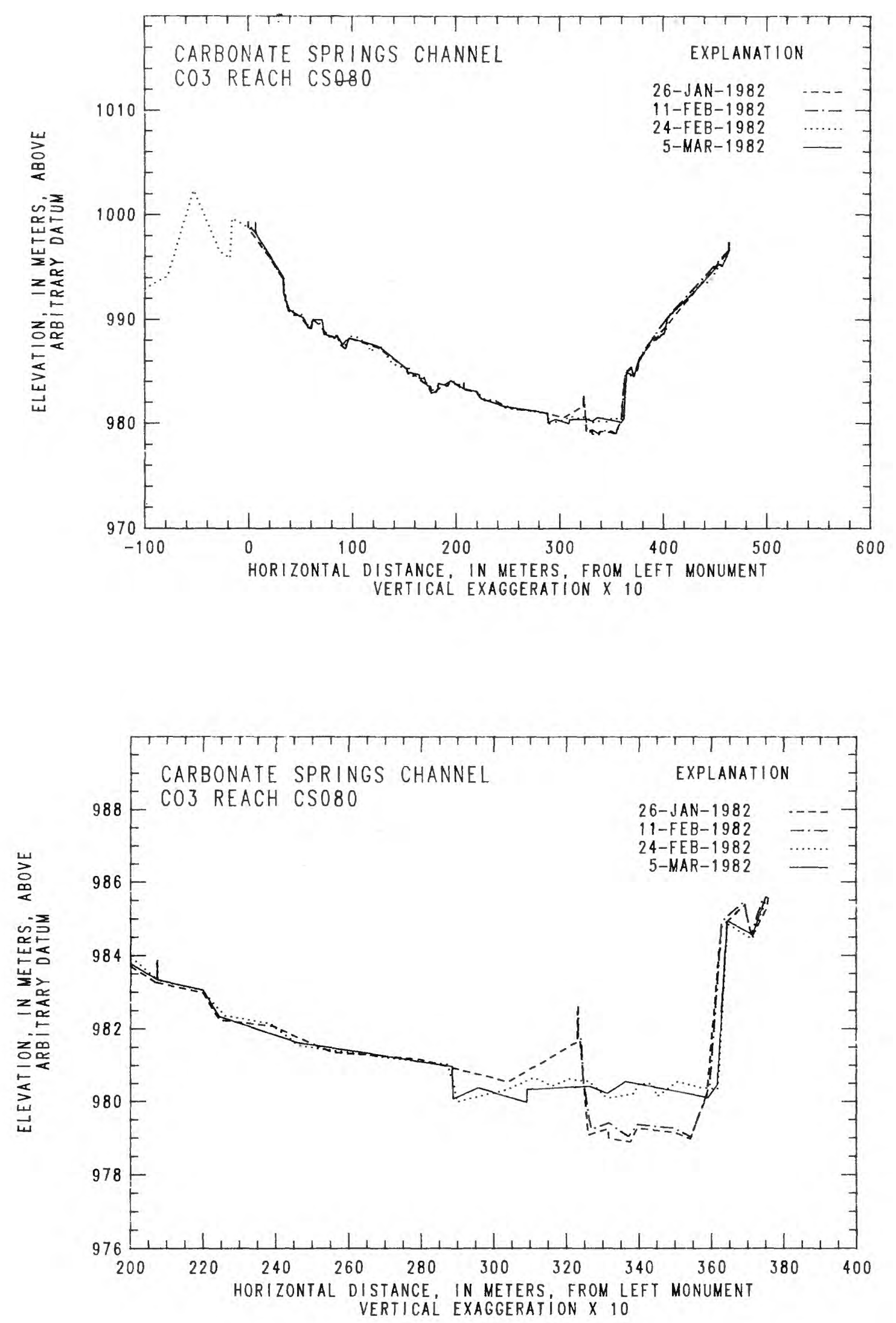

Figure 13.--Channel cross-section profiles for selected sites, North Fork Toutle River--Continued 
Abstract-_- 1

Int roduction-_-_-_-_ 2

Drainage basin characteristics and volcanic impacts-___-_ 3

Green River-

North Fork Toutle River-

South Fork Toutle River-_____-_ 6

Toutle River- 11

Hydrology-- 15

Methods of data collection- 18

Cross section location-- 18

Surveying methods-_- 20

References- 21 

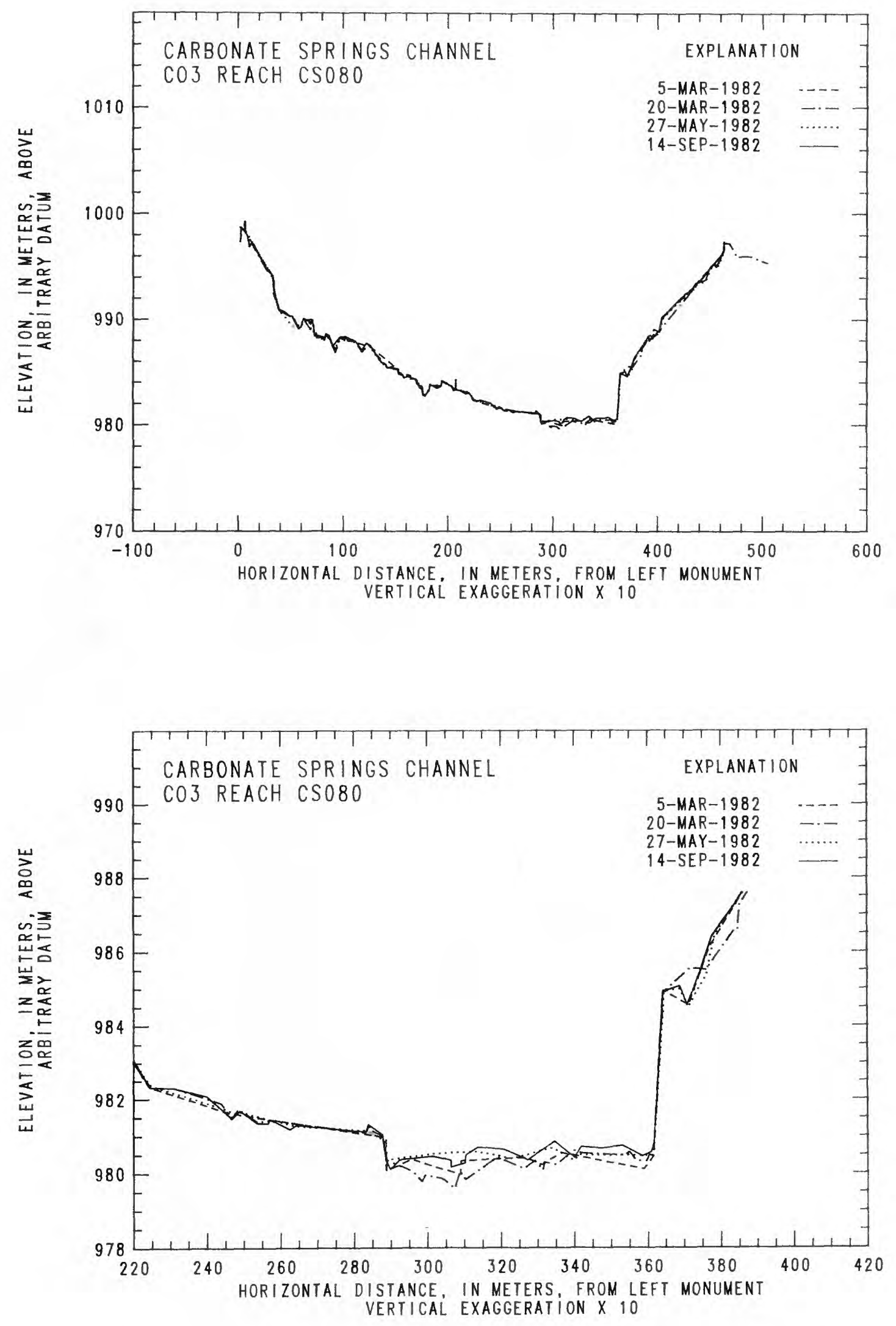

Figure 13.--Channel cross-section profiles for selected sites, North Fork Toutle River--Continued 

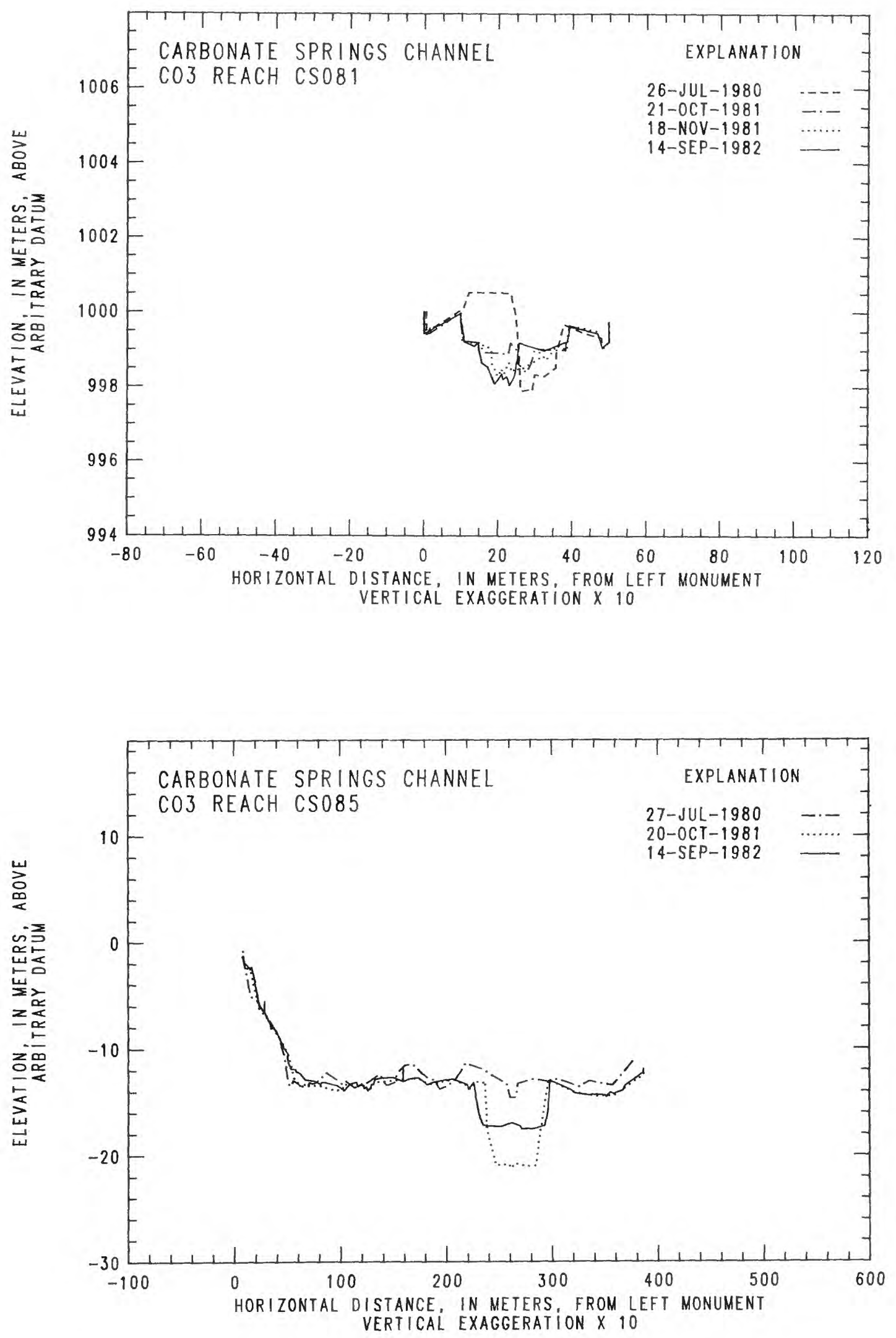

Figure 13.--Channel cross-section profiles for selected sites, North Fork Toutle River--Continued 

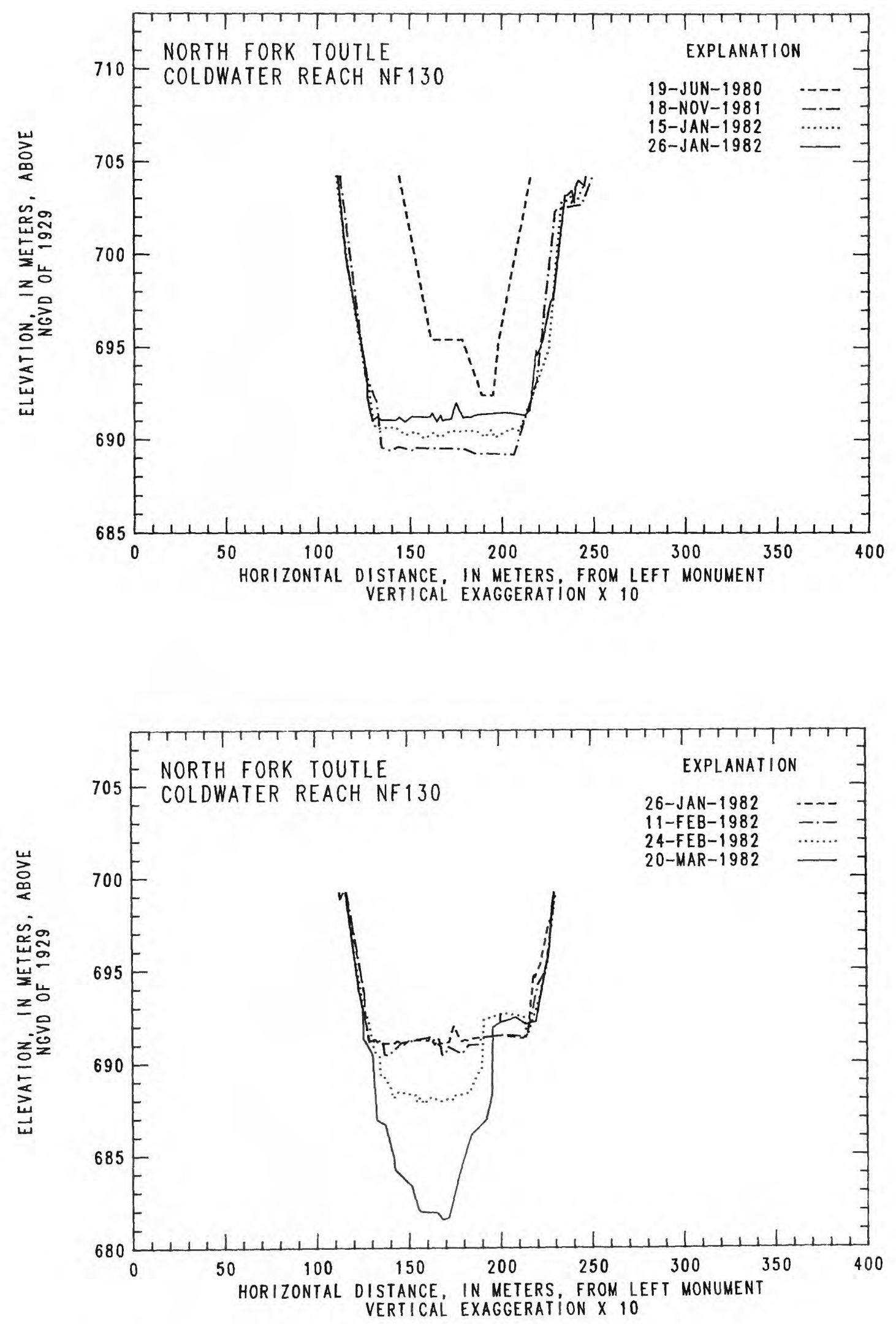

Figure 13.--Channel cross-section profiles for selected sites, North Fork Toutle River--Continued 

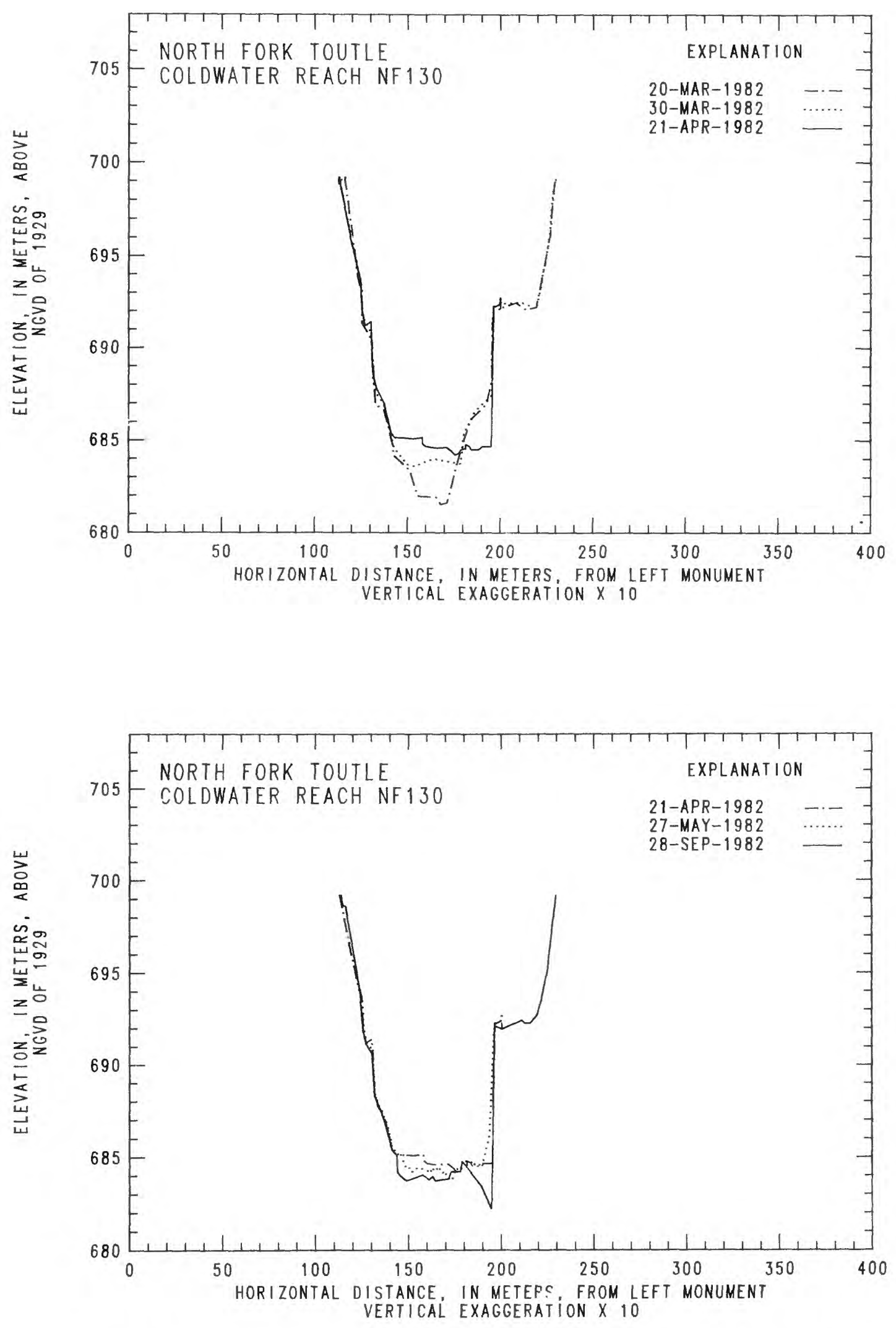

Figure 13.--Channel cross-section profiles for selected sites, North Fork Toutle River--Continued 

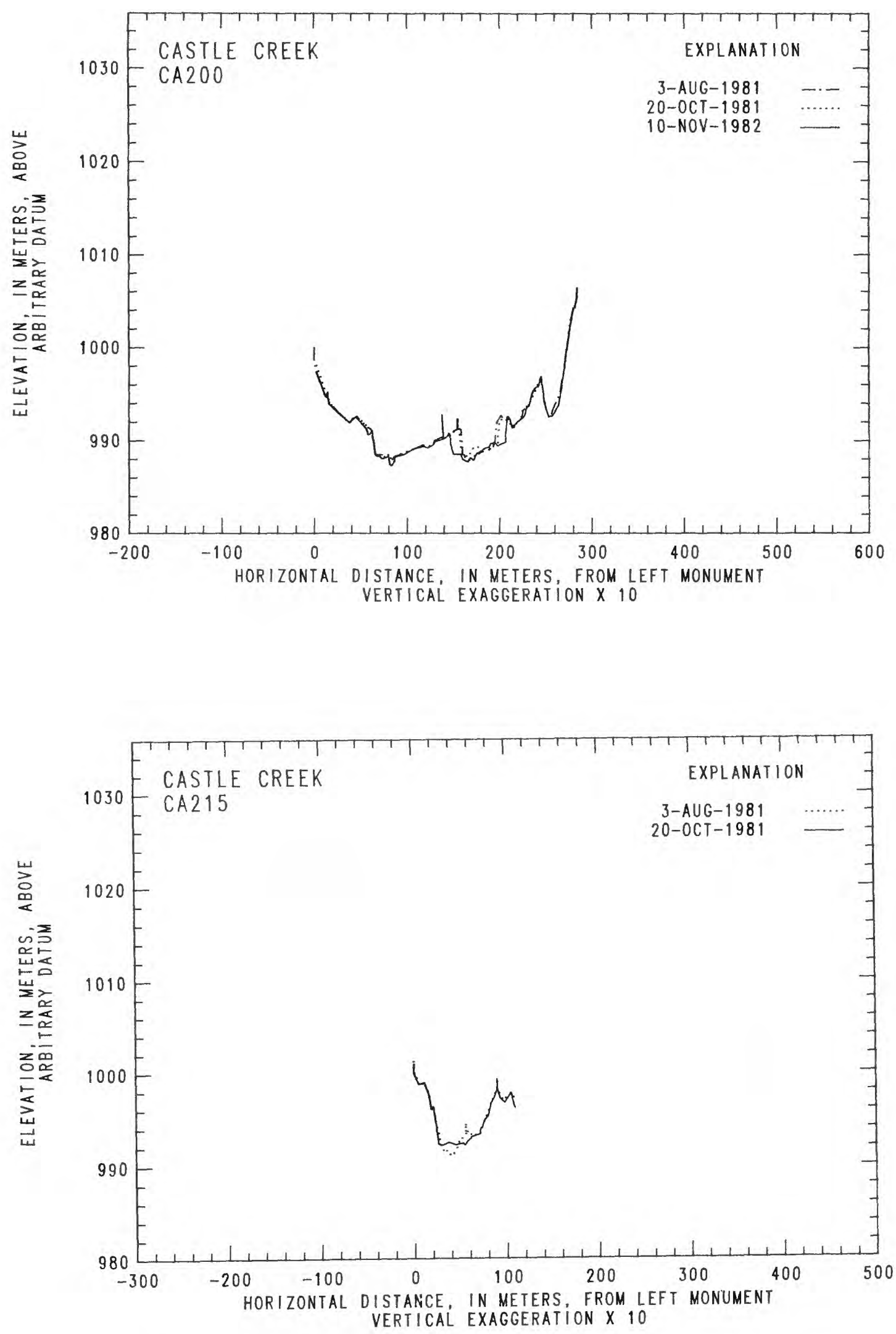

Figure 13.--Channel cross-section profiles for selected sites, North Fork Toutle River--Continued 

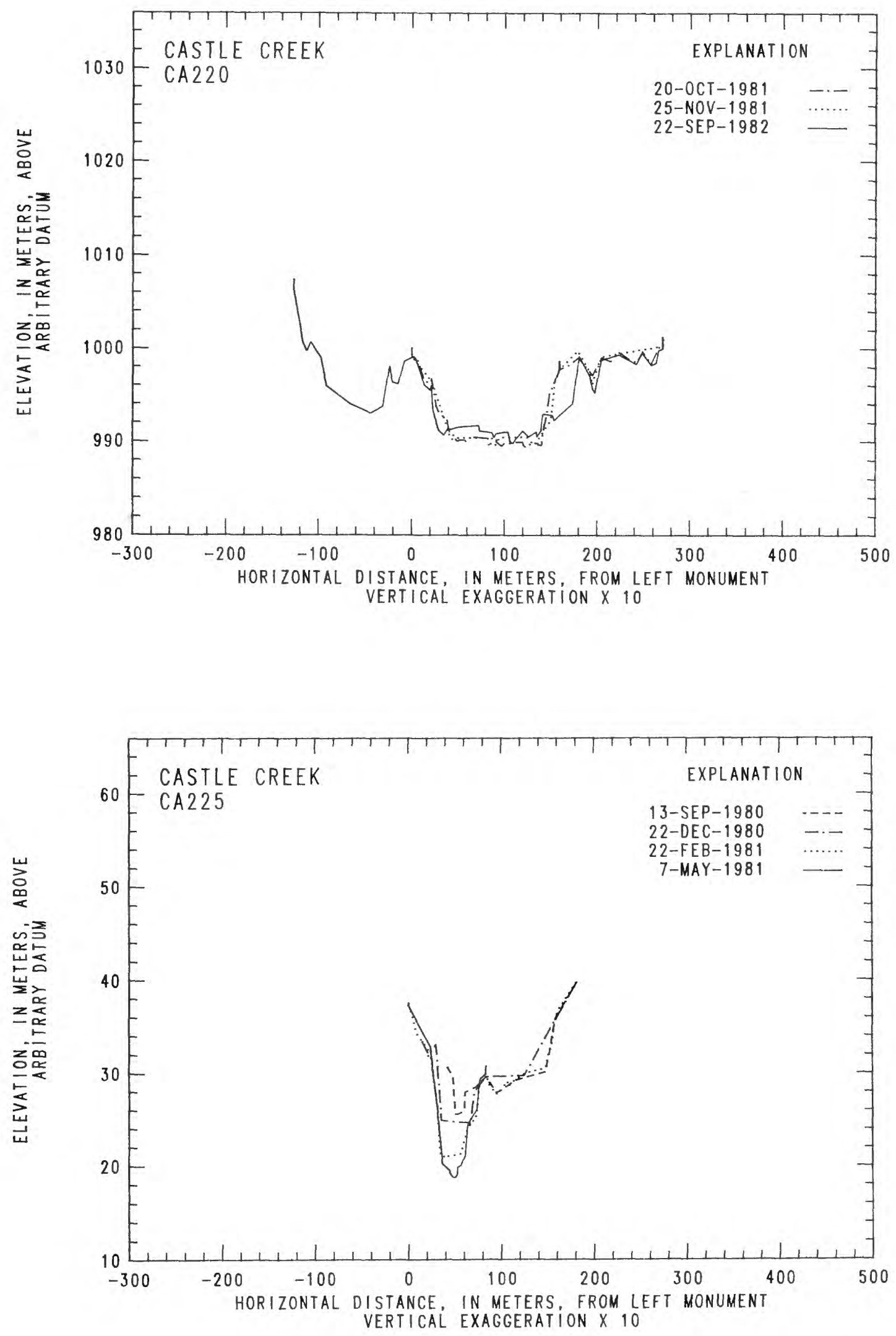

Figure 13.--Channel cross-section profiles for selected sites, North Fork Toutle River--Continued 

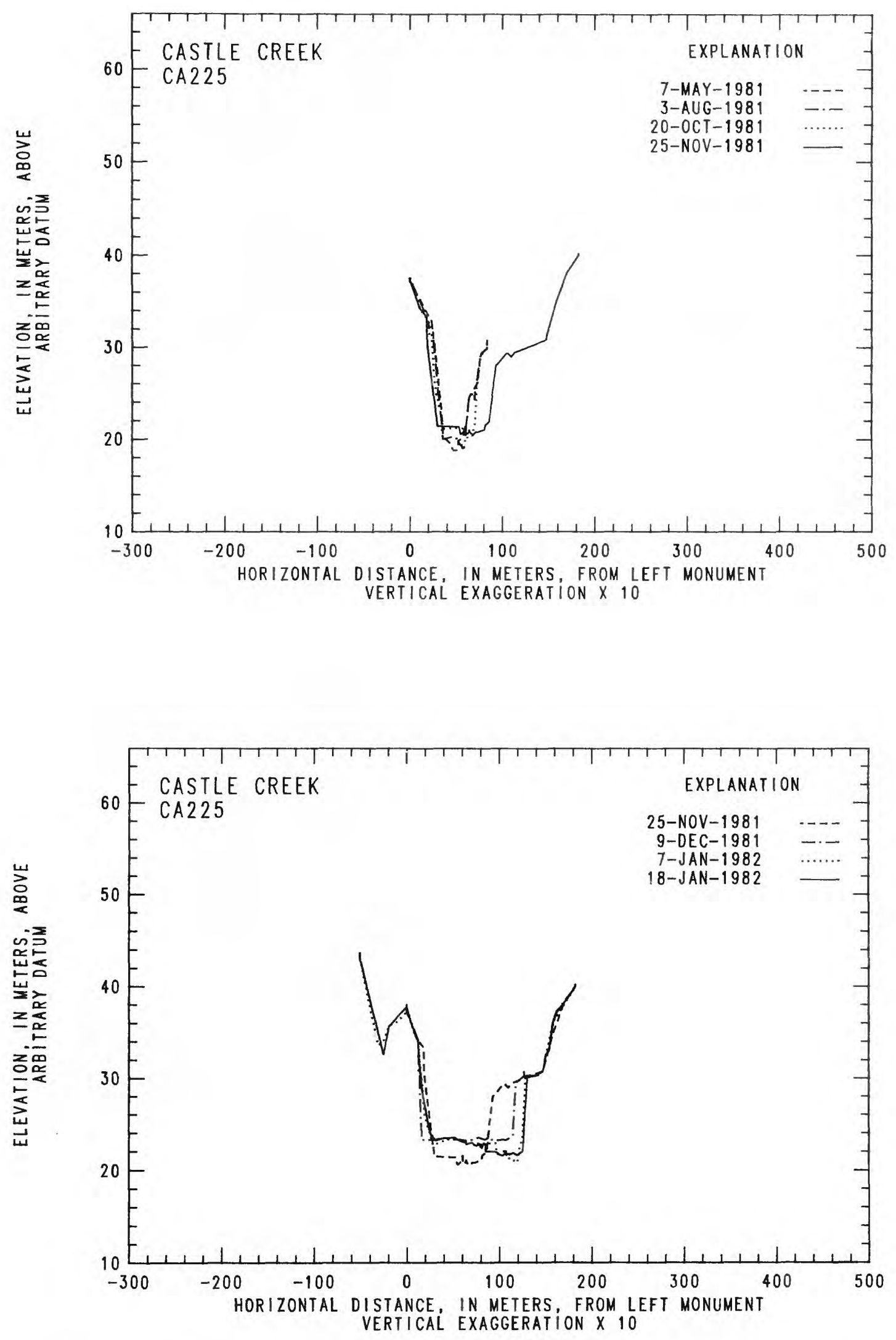

Figure 13.--Channel cross-section profiles for selected sites, North Fork Toutle River--Continued 

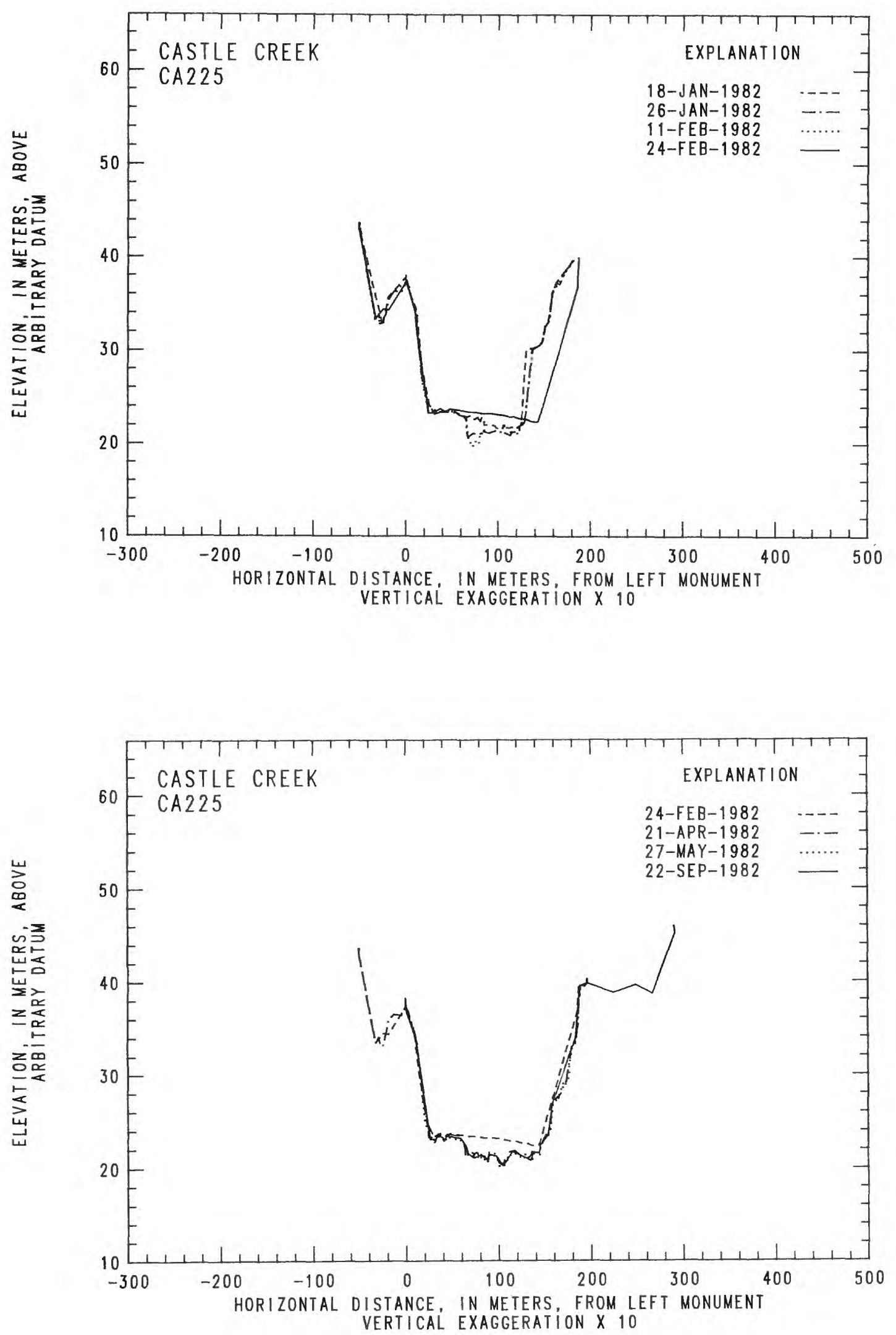

Figure 13.--Channel cross-section profiles for selected sites, North Fork Toutle River--Continued 

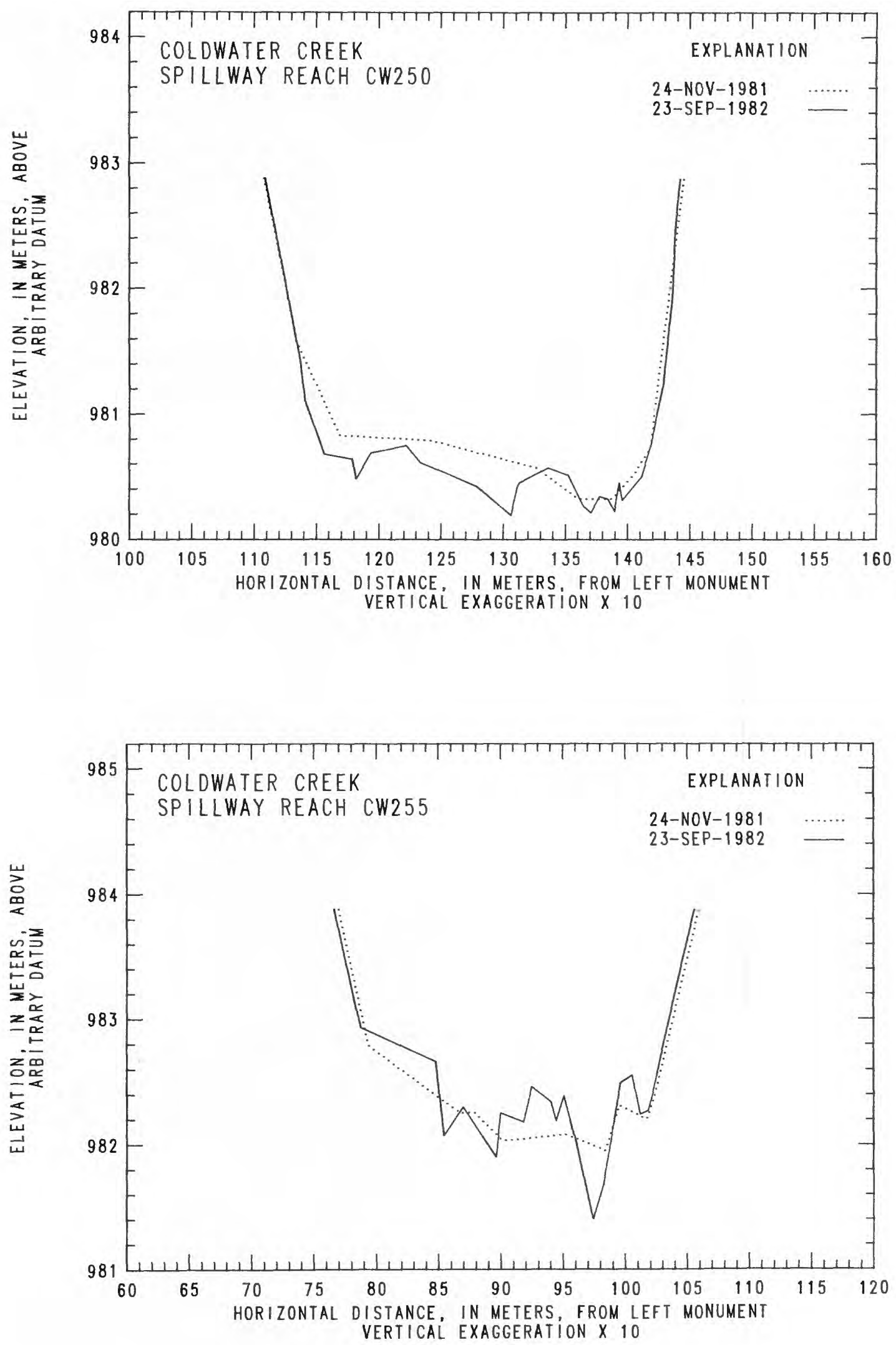

Figure 13.--Channel cross-section profiles for selected sites, North Fork Toutle River--Continued 

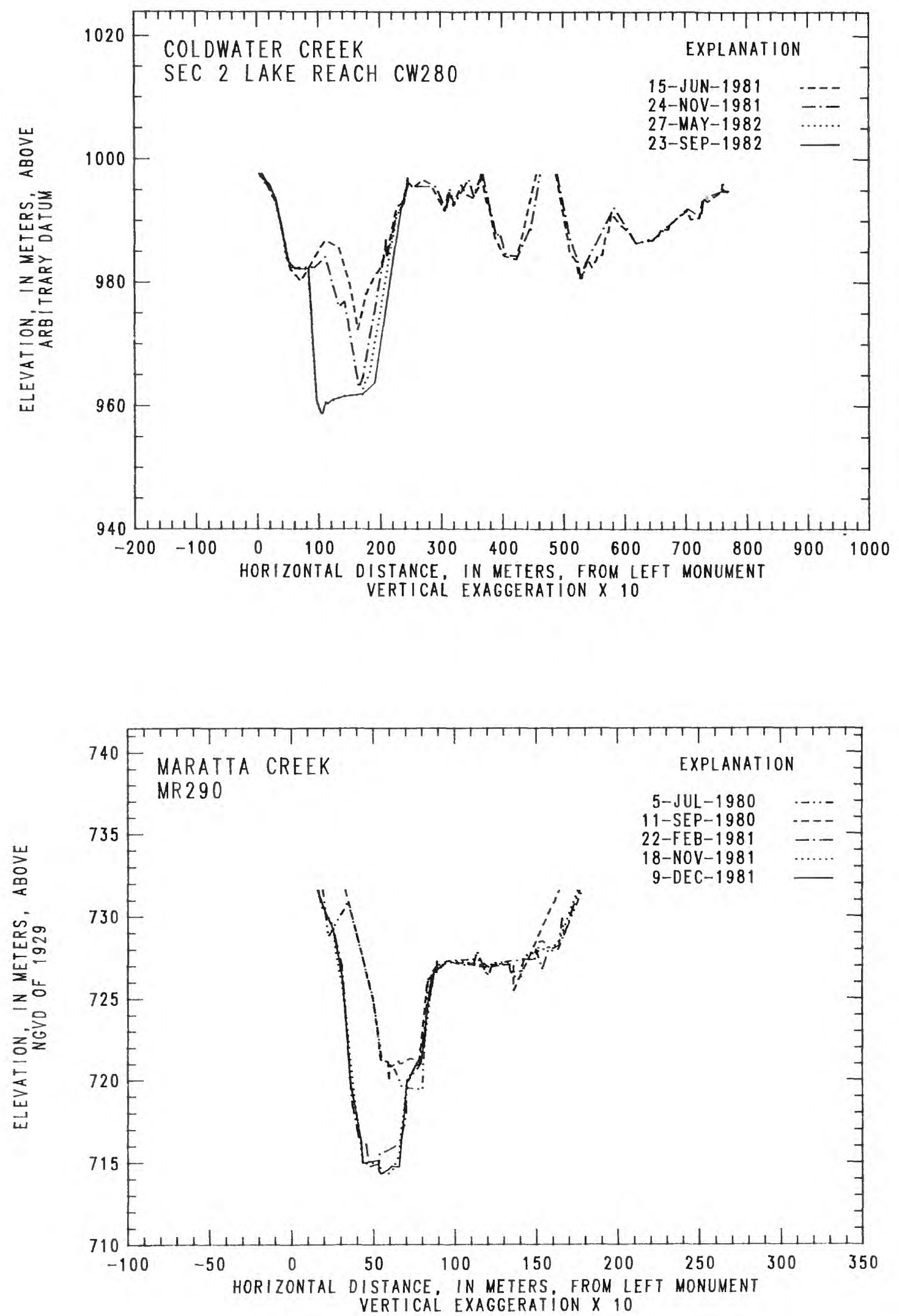

Figure 13.--Channel cross-section profiles for selected sites, North Fork Toutle River--Continued 
FIGURE 1. Map showing location of Toutle River drainage, Mount St. Helens, lateral blast-affected area, and debris-avalanche deposits-- - - - -

2. Map showing location of channel cross sections on the Green River, North Fork Toutle River, and South Fork Toutle River-------7

3. Map showing location of channel cross sections on the Green River, North Fork Toutle River and its tributaries, and South Fork Toutle River-- - -

4. Map showing location of channel cross sections on the Green River and upper North Fork Toutle River and its tributaries and South Fork Toutle River----

5. Map showing location on channel cross sections on the upper Toutle River, lower North Fork Toutle River, and lower South Fork Toutle River---_-

6. Map showing location of channel cross section on the lower Toutle River---- -

7. Graph of drainage integration, with time, of upper North Fork Toutle River basin, above the $\mathrm{N}-1$ debris retention structure--- 14

$8 a-8 c$. Annual hydrograph of daily mean discharge for Cowlitz River at Castle Rock, Washington:
a. water year 1980
b. water year 1981
c. water year 1982

9a-9c. Annual hydrograph of daily mean discharge for North Fork Toutle River at Kid Valley, Washington:
a. water year 1980
b. water year 1981
c. water year 1982

10. Graph of longitudinal profile of Green River, showing locations of cross sections-

11. Plots of channel cross-section profiles for selected sites, Green River--

12. Graph of longitudinal profile of North Fork Toutle River, showing locations of cross sections-

13. Plots of channel cross-section profiles for selected sites, North Fork Toutle River-

14. Graph of longitudinal profile of South Fork Toutle River, showing locations of cross sections--

15. Plots of channel cross-section profiles for selected sites, South Fork Toutle River--

16. Graph of longitudinal profile of Toutle River, showing locations of cross sections--

17. Plots of channel cross-section profiles for selected sites, Toutle River- 113 

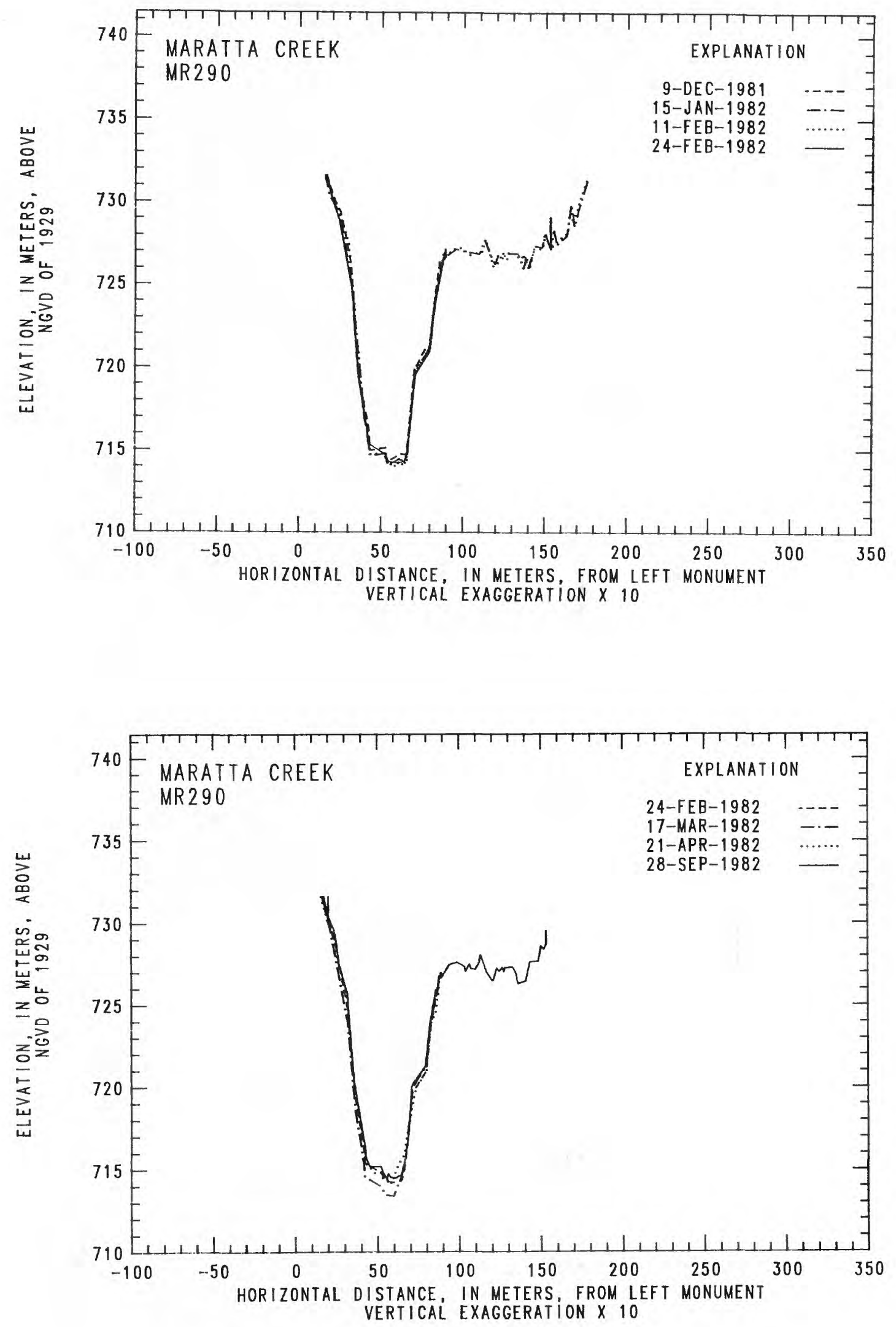

Figure 13.--Channel cross-section profiles for selected sites, North Fork Toutle River--Continued 

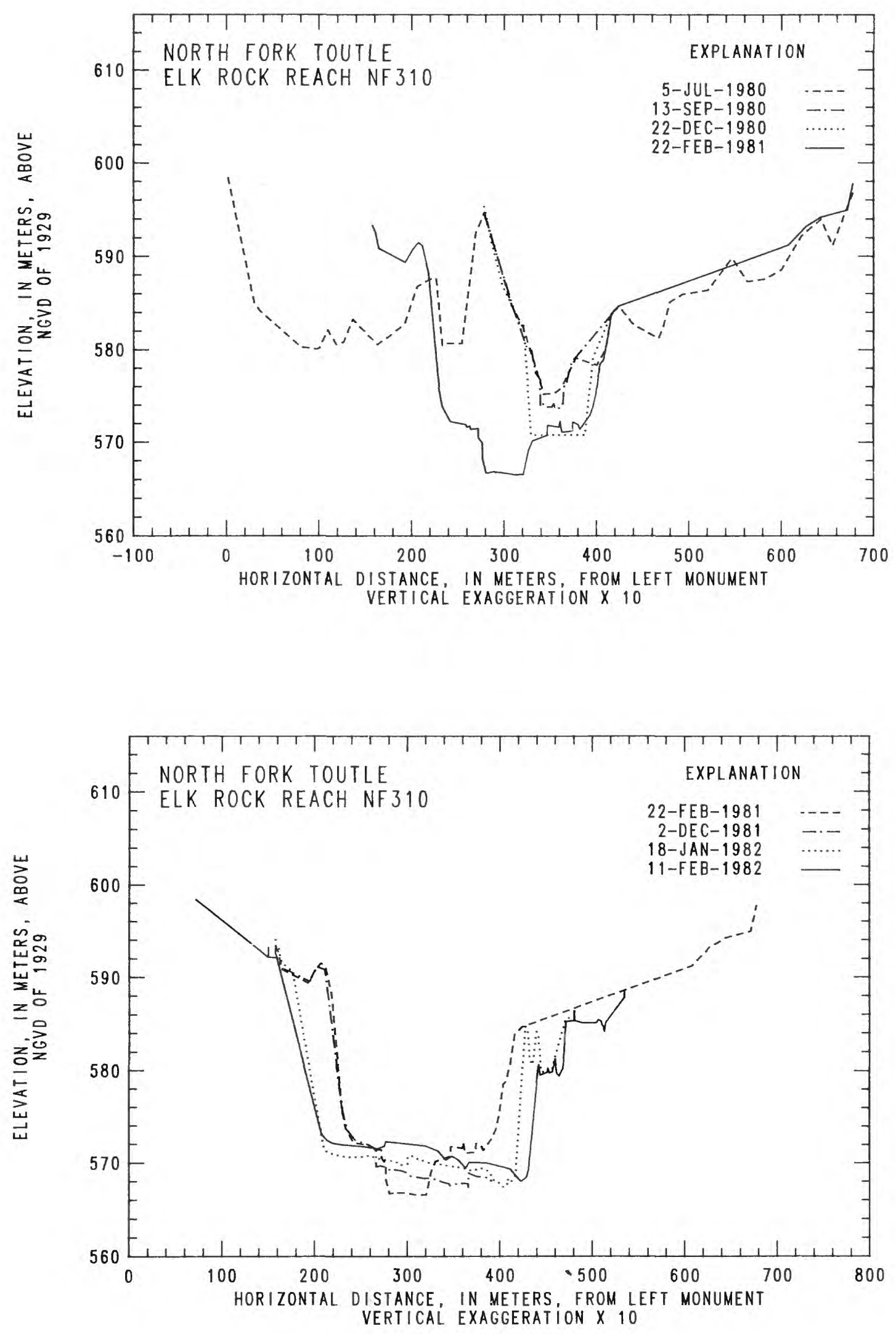

Figure 13.--Channel cross-section profiles for selected sites, North Fork Toutle River--Continued 

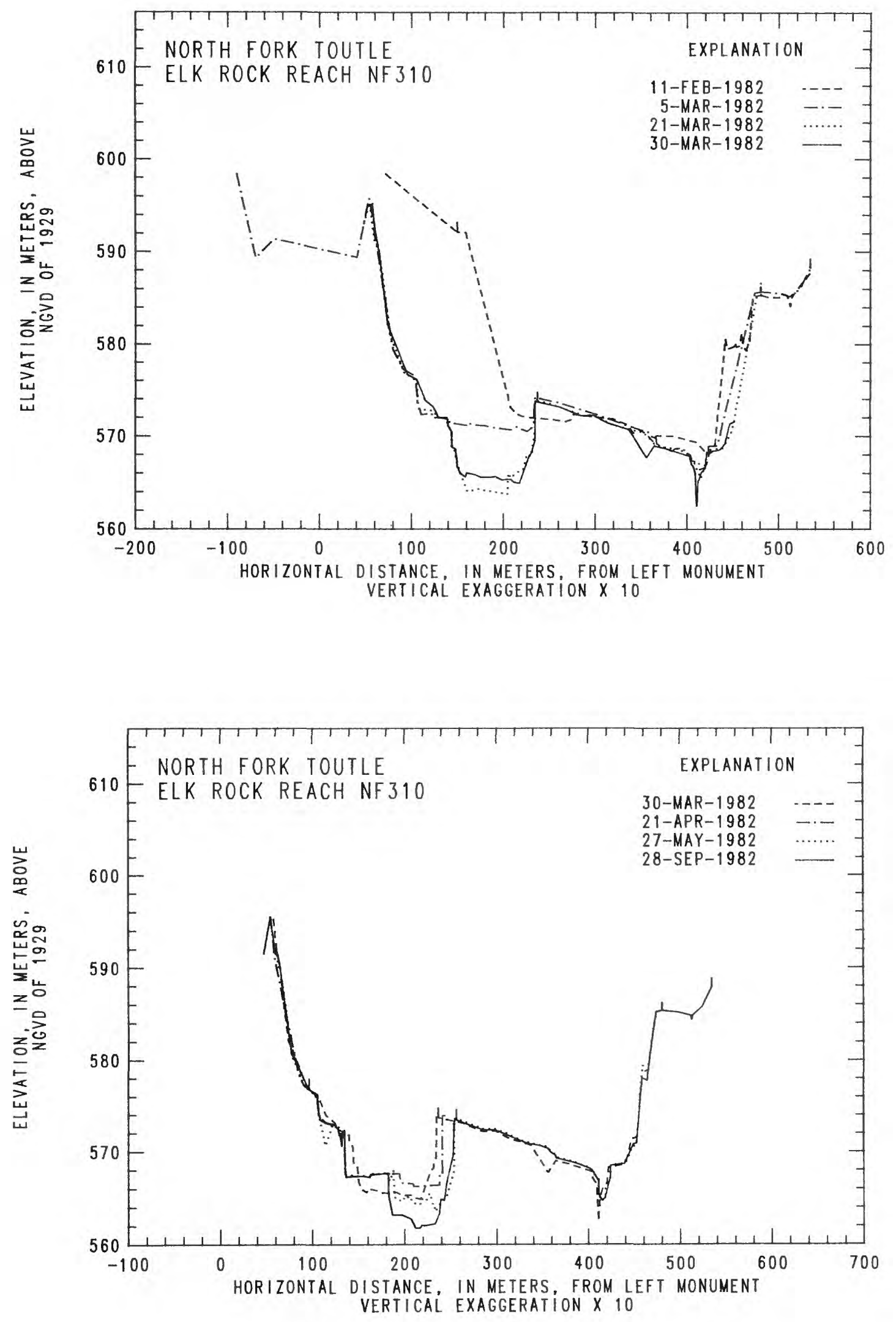

Figure 13.--Channel cross-section profiles for selected sites, North Fork Toutle River--Continued 

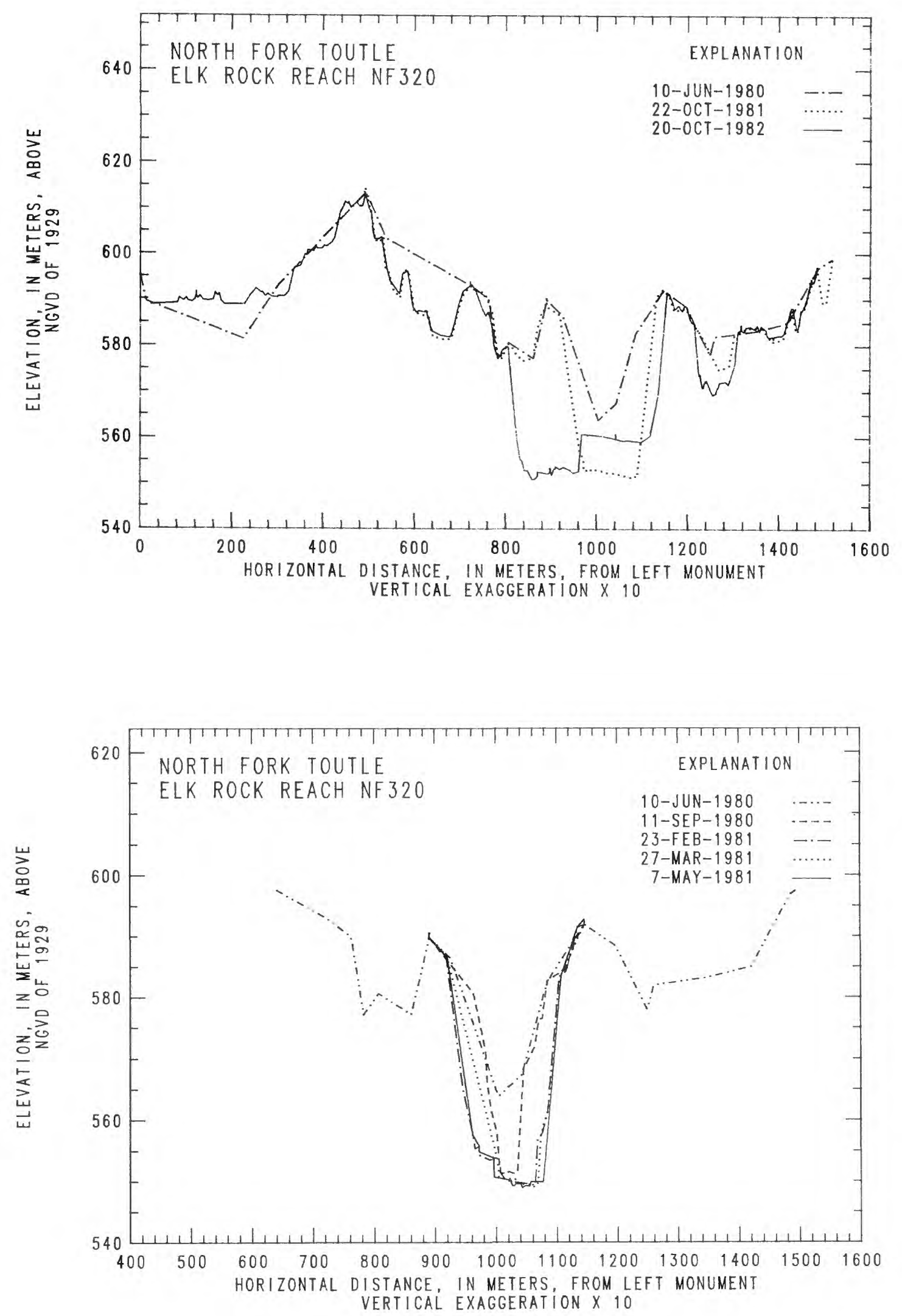

Figure 13.--Channel cross-section profiles for selected sites, North Fork Toutle River--Continued 

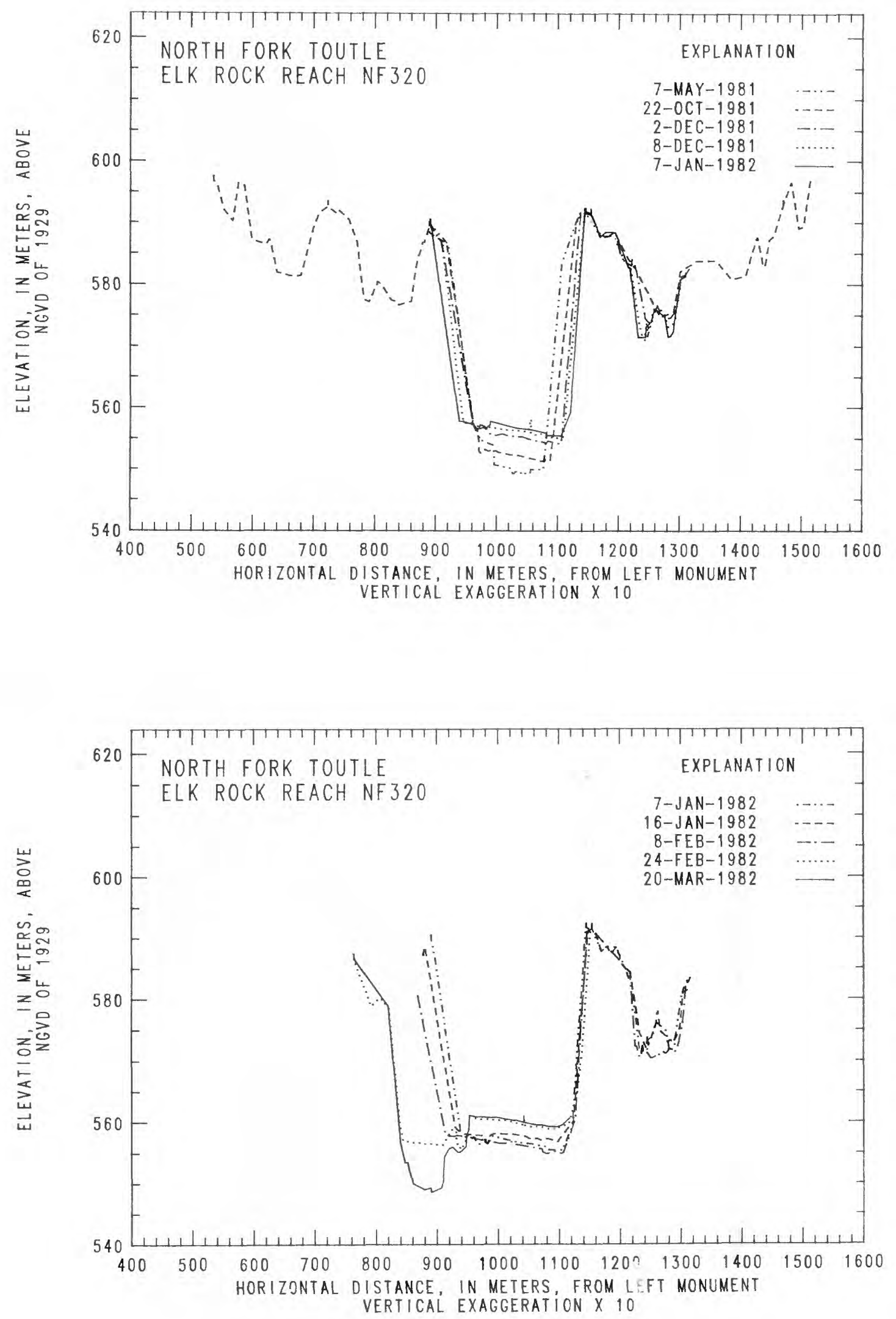

Figure 13.--Channe1 cross-section profiles for selected sites, North Fork Toutle River--Continued 

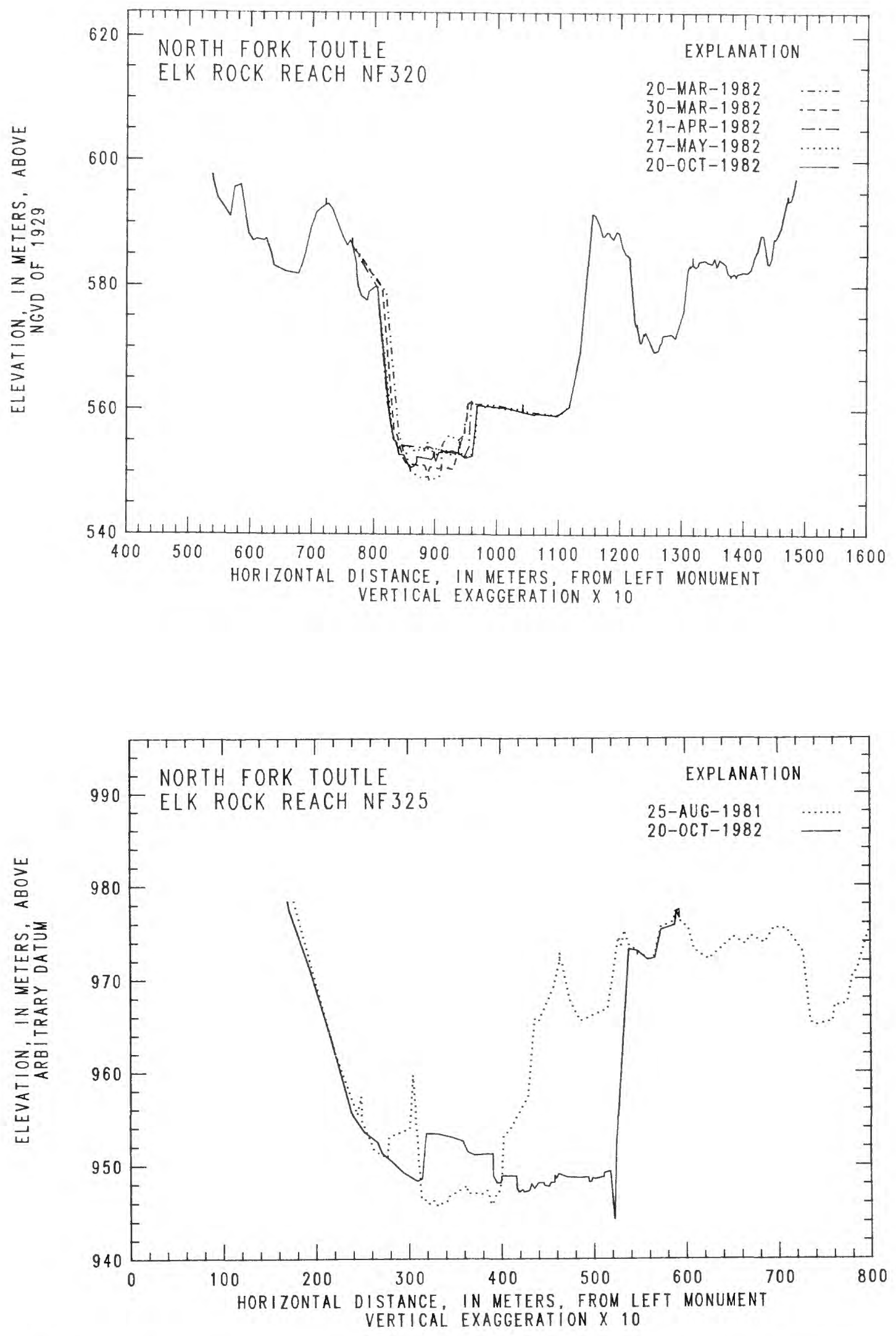

Figure 13.--Channel cross-section profiles for selected sites, North Fork Toutle River--Continued 

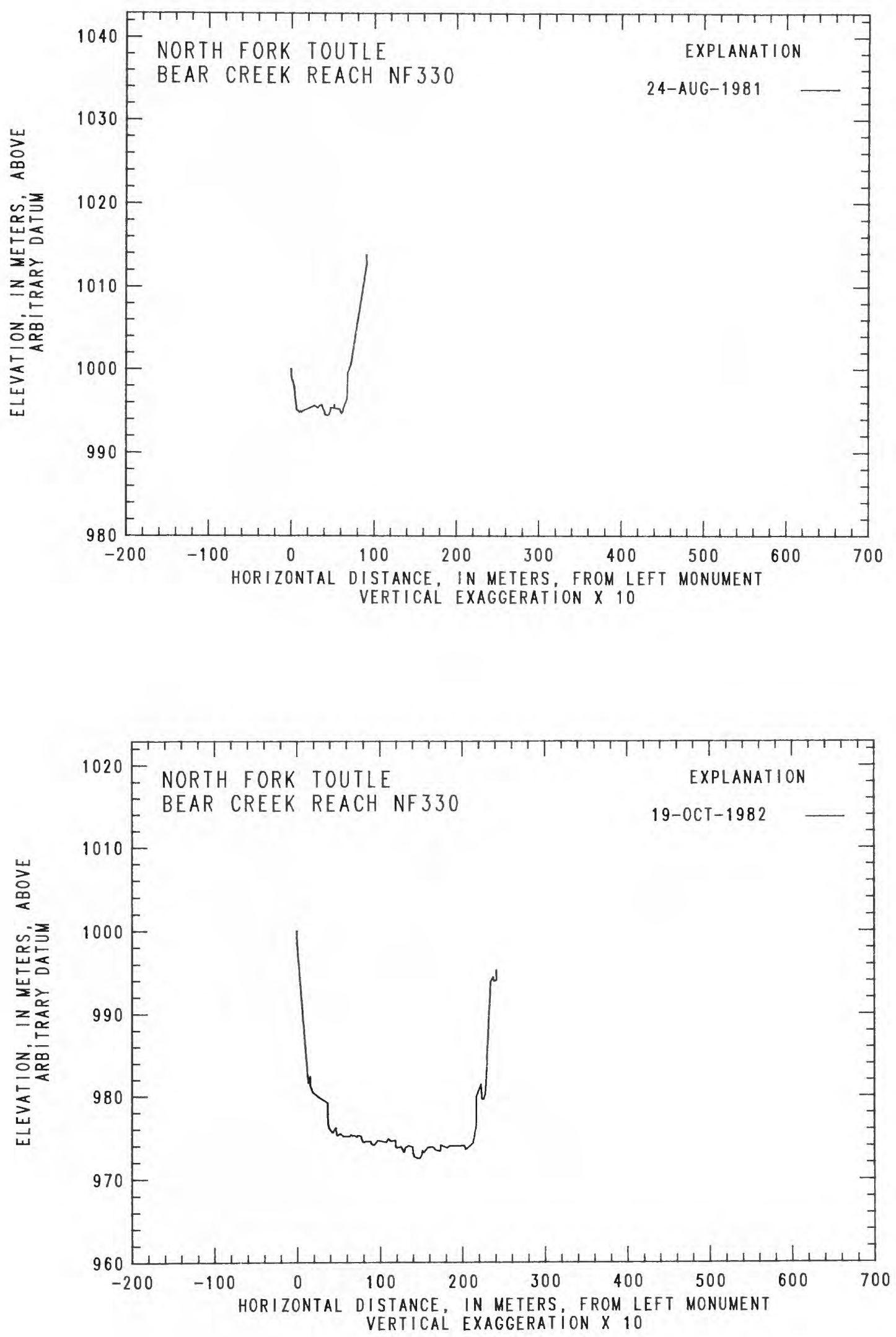

Figure 13.--Channel cross-section profiles for selected sites, North Fork Toutle River--Continued 

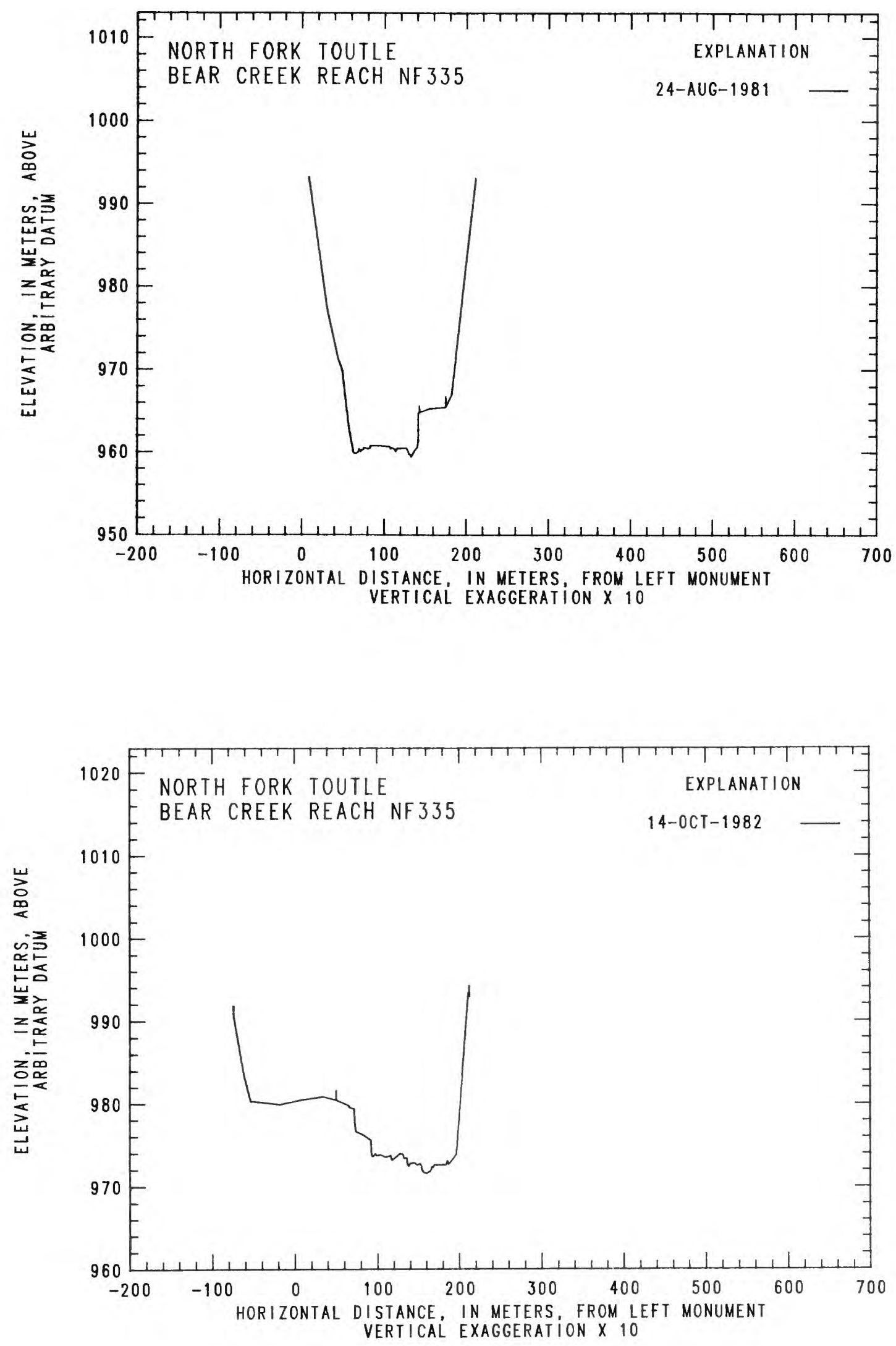

Figure 13.--Channel cross-section profiles for selected sites, North Fork Toutle River--Continued 

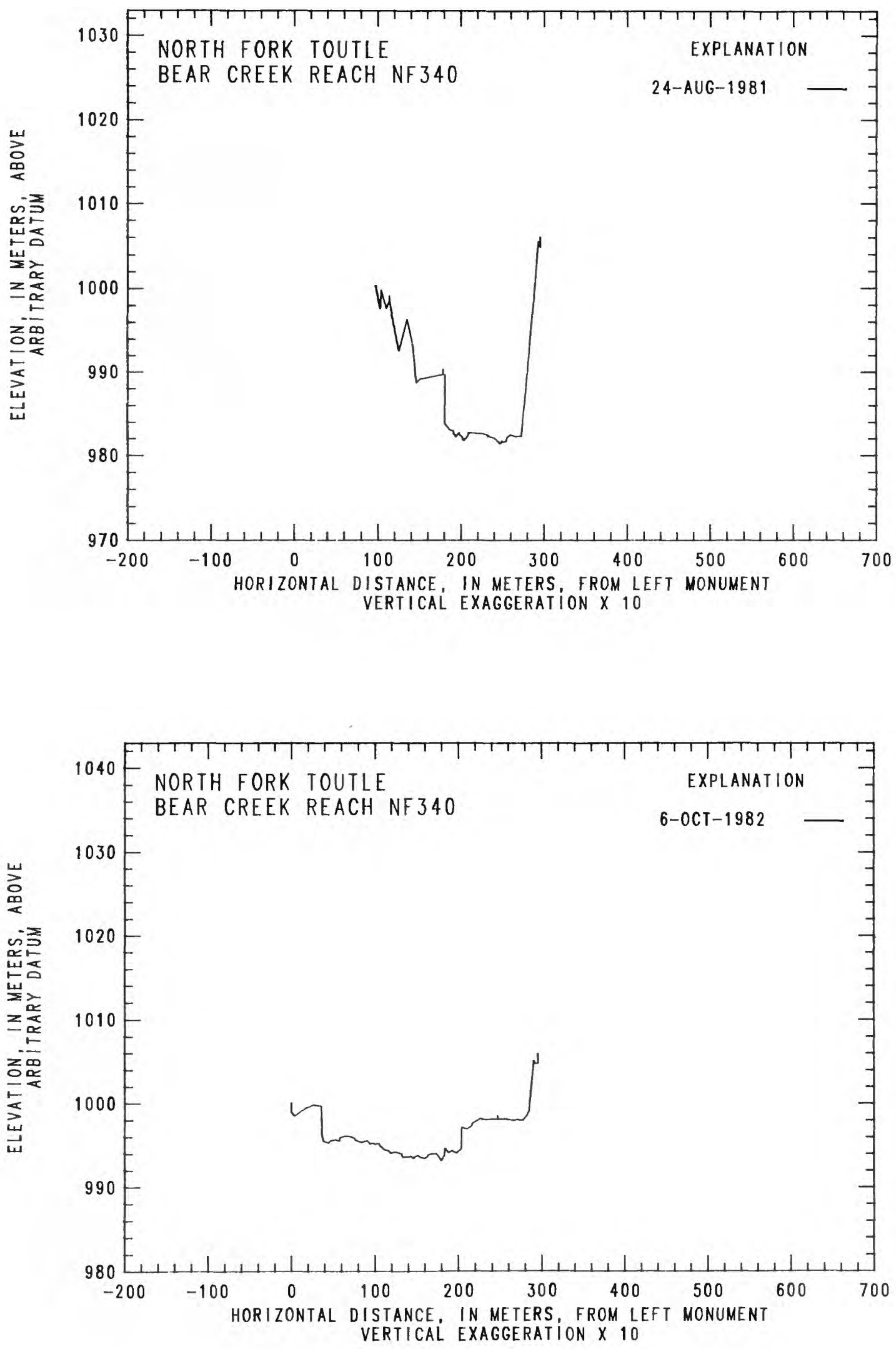

Figure 13.--Channel cross-section profiles for selected sites, North Fork Toutle River--Continued 

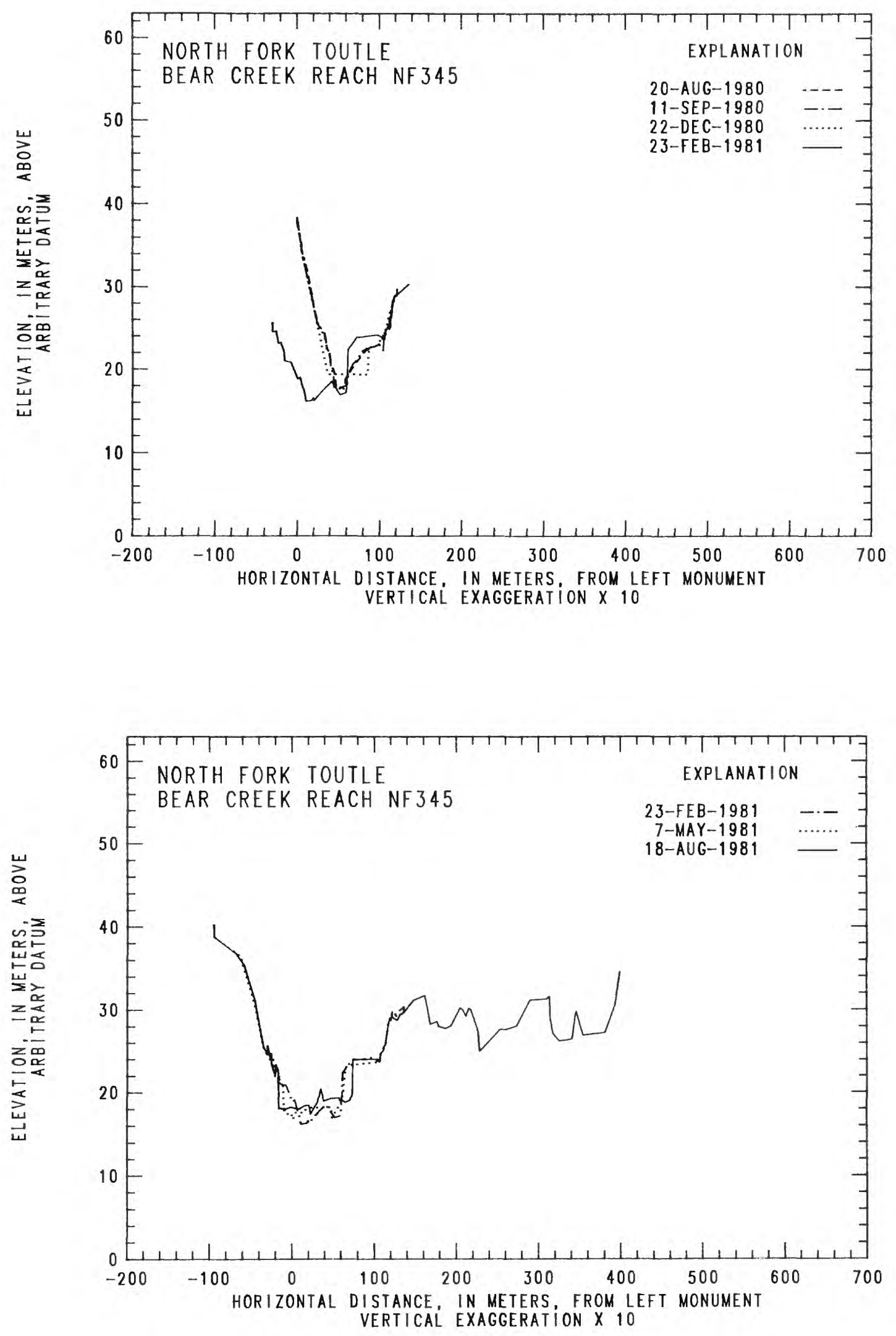

Figure 13.--Channel cross-section profiles for selected sites, North Fork Toutle River--Continued 
Table 1. Peak discharge and runoff for major discharge events----- 5

2. Drainage basin statistics- 10

3. Description of the cross-section network-_- 19 

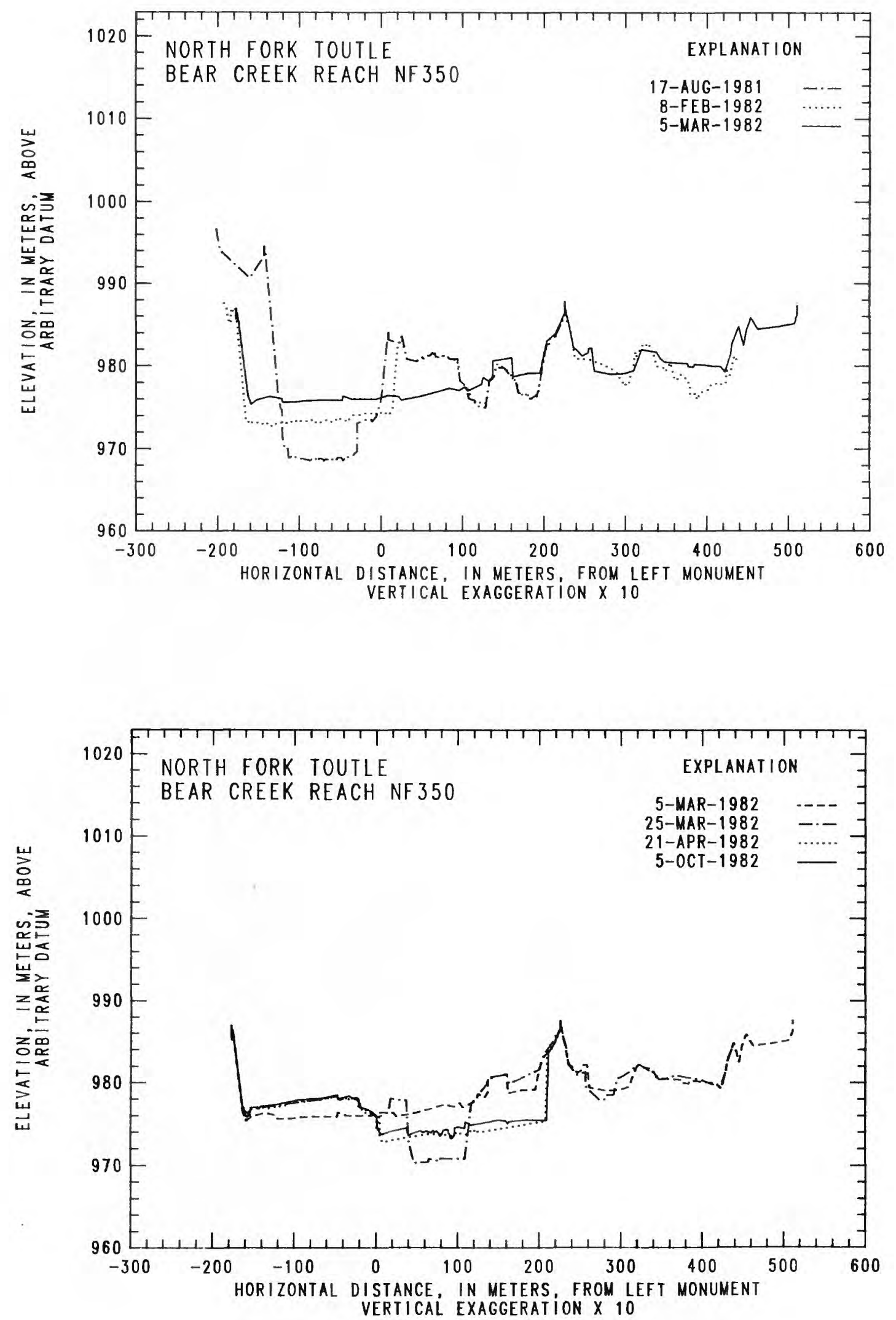

Figure 13.--Channel cross-section profiles for selected sites, North Fork Toutle River--Continued 

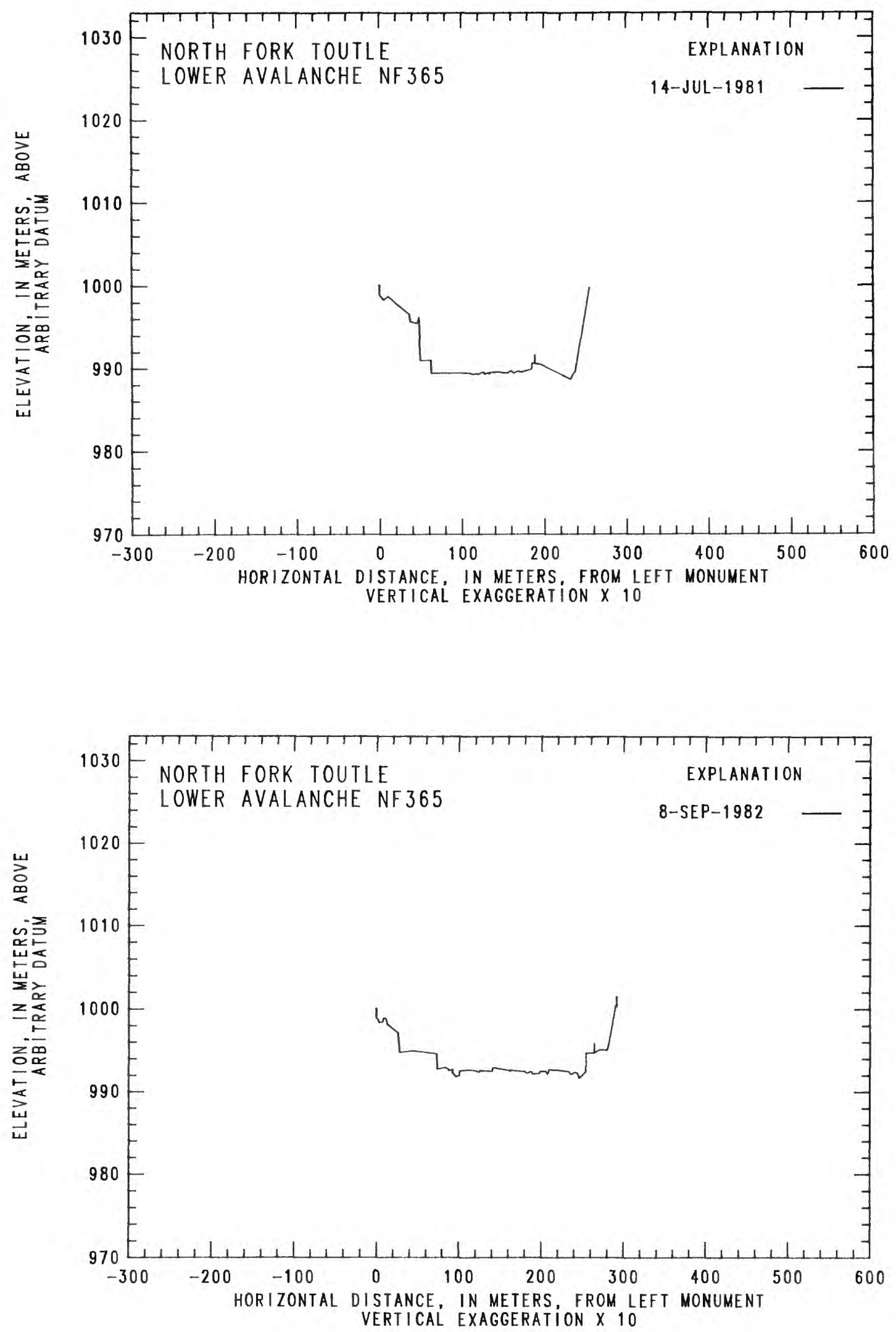

Figure 13.--Channel cross-section profiles for selected sites, North Fork Toutle River--Continued 

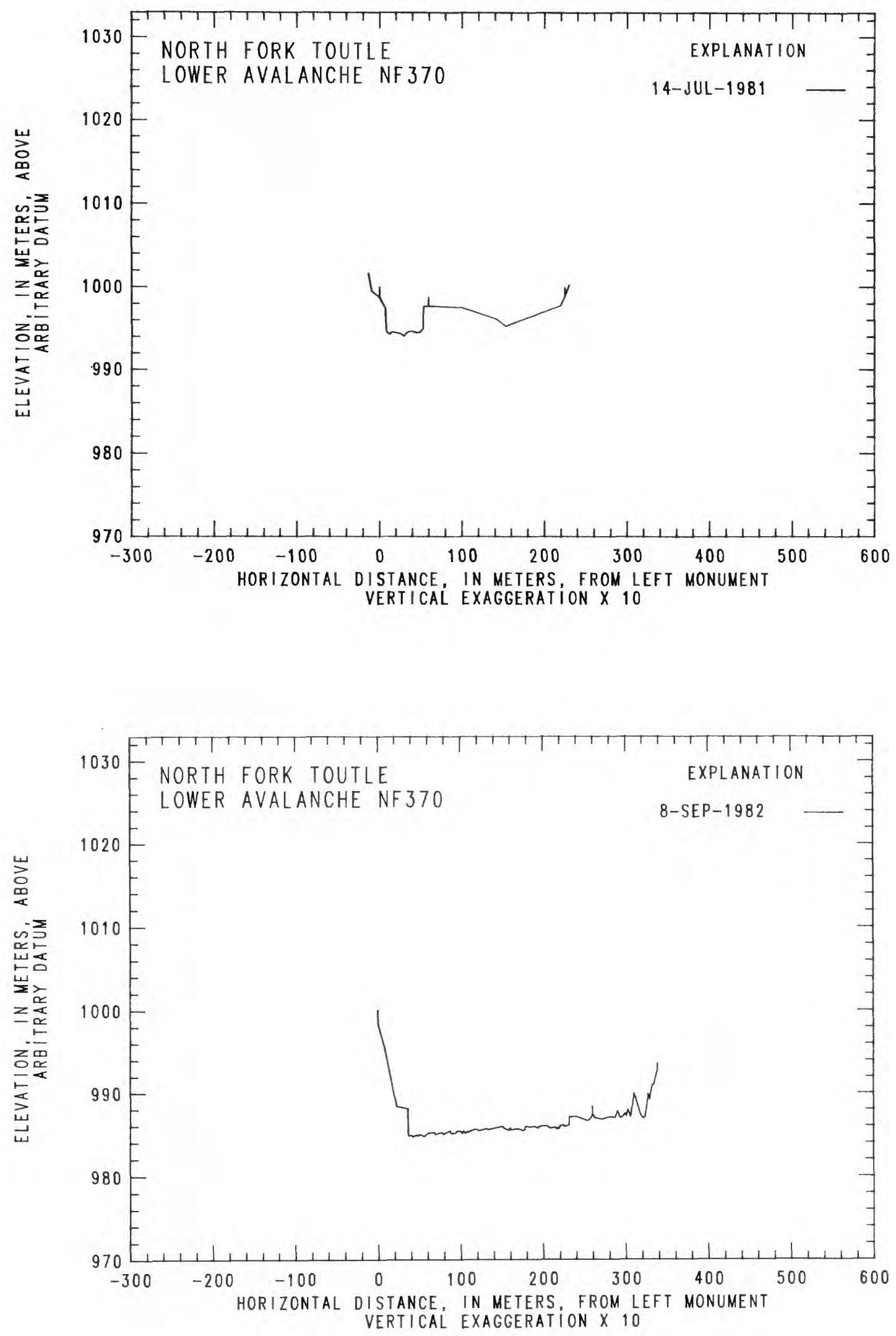

Figure 13.--Channel cross-section profiles for selected sites, North Fork Toutle River--Continued 

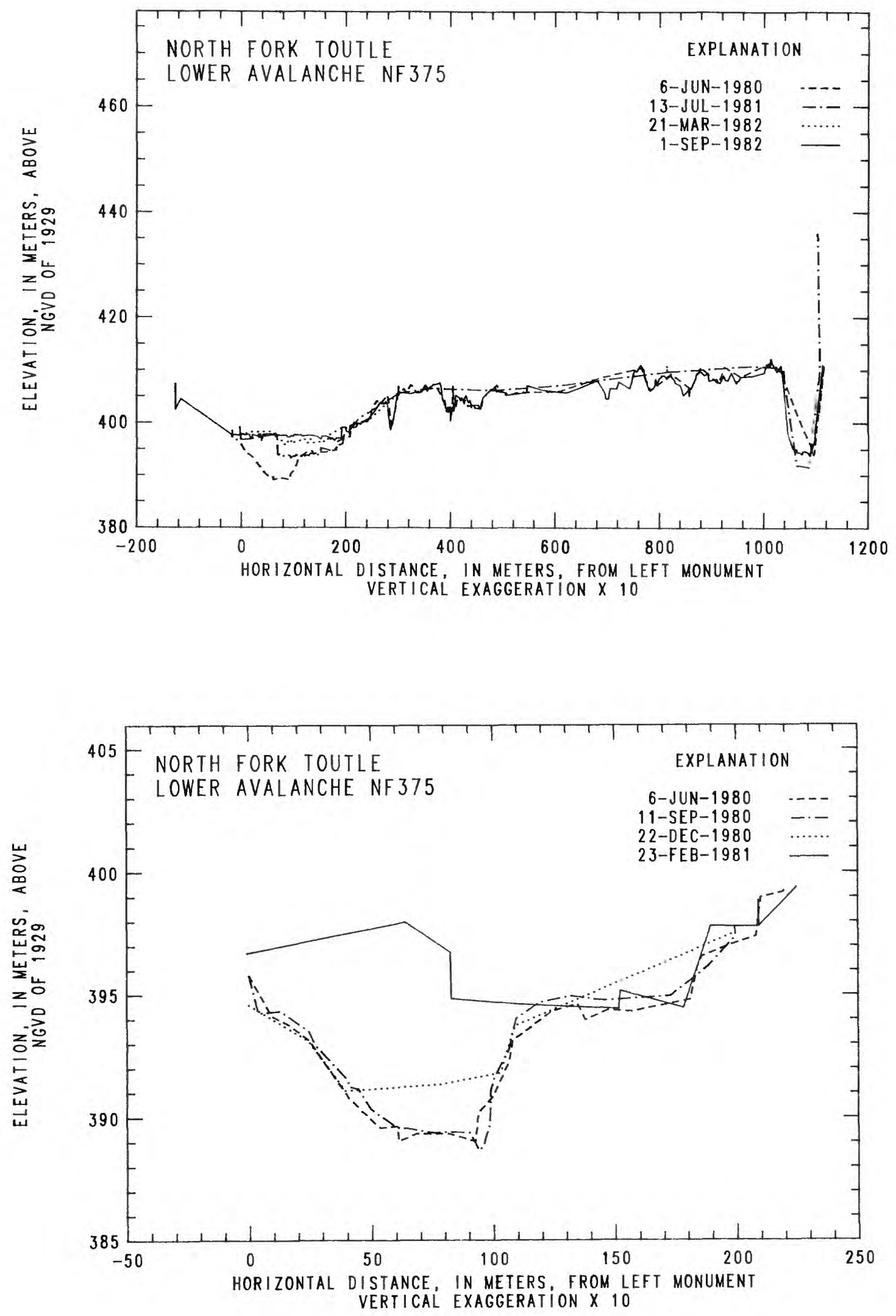

Figure 13.--Channel cross-section profiles for selected sites, North Fork Toutle River--Continued 

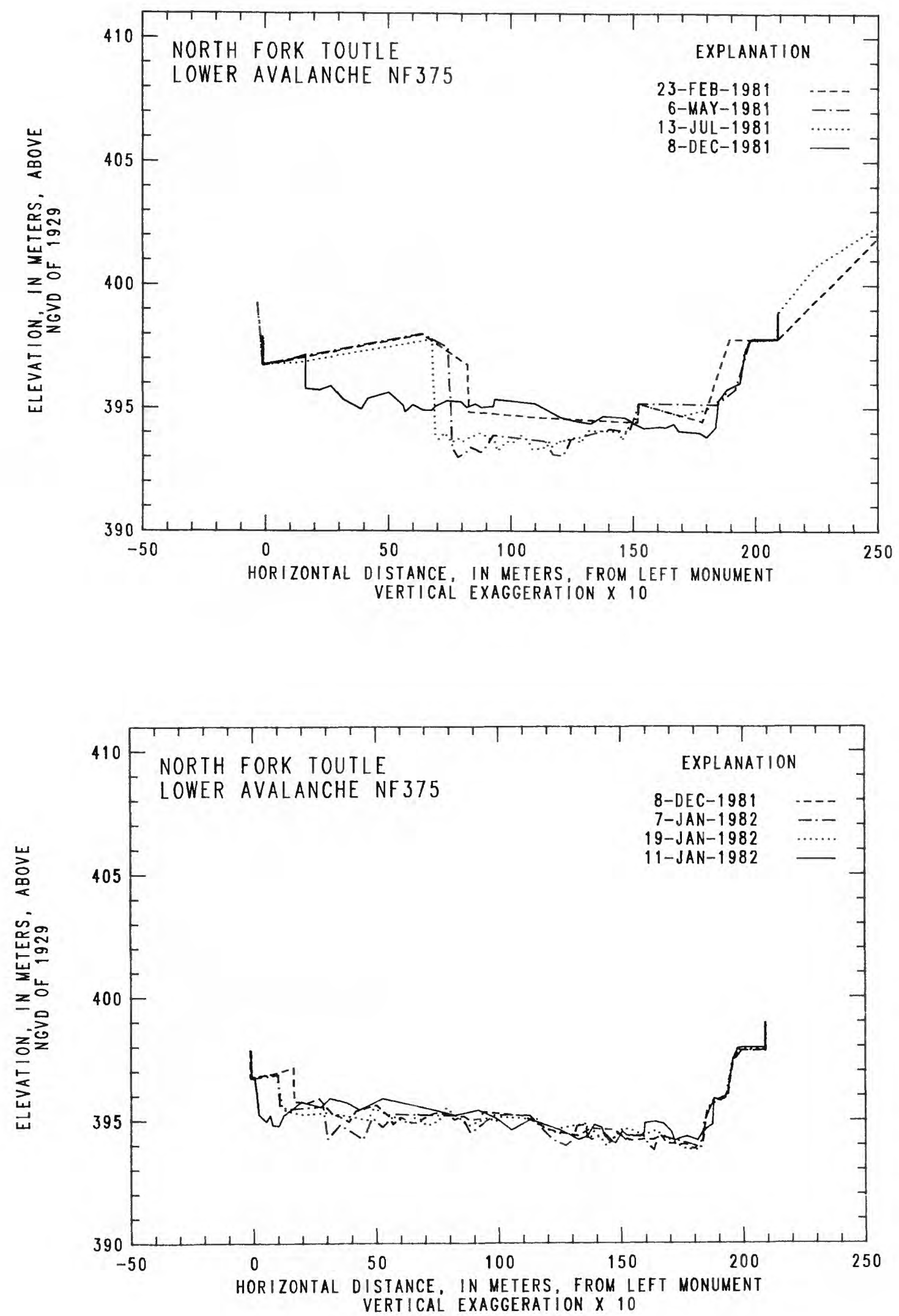

Figure 13.--Channel cross-section profiles for selected sites, North Fork Toutle River--Continued 

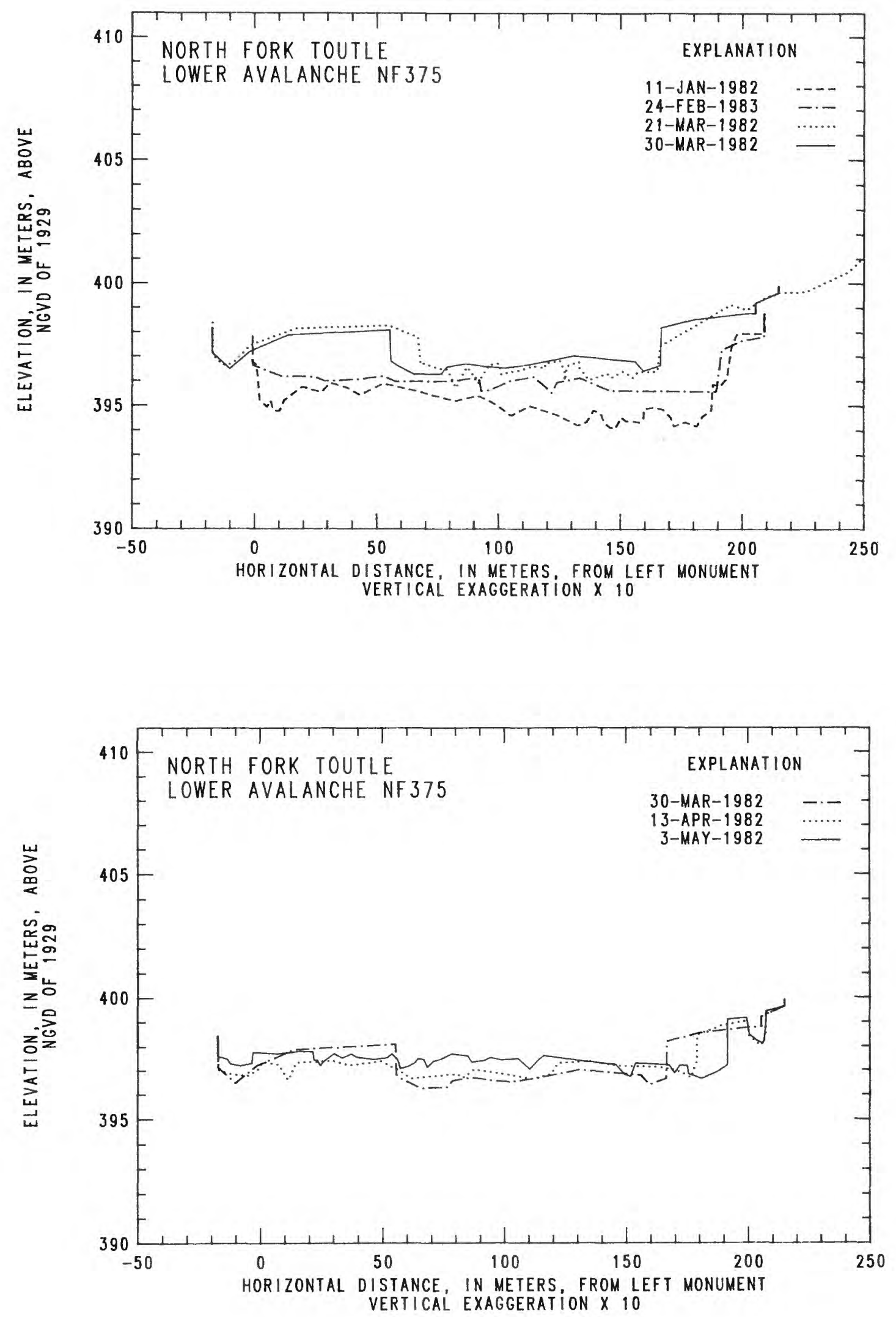

Figure 13.--Channel cross-section profiles for selected sites, North Fork Toutle River--Continued 

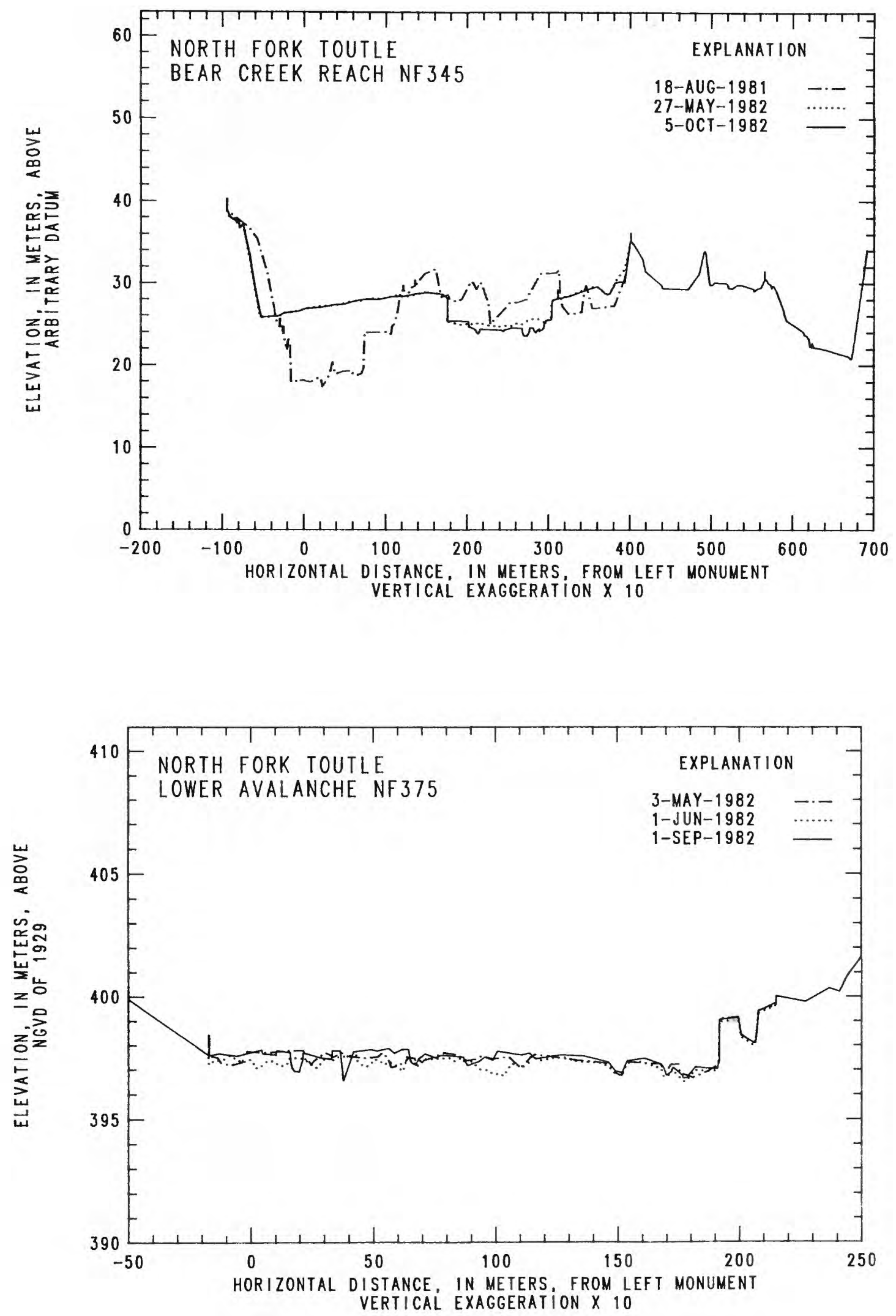

Figure 13.--Channel cross-section profiles for selected sites, North Fork Toutle River--Continued 

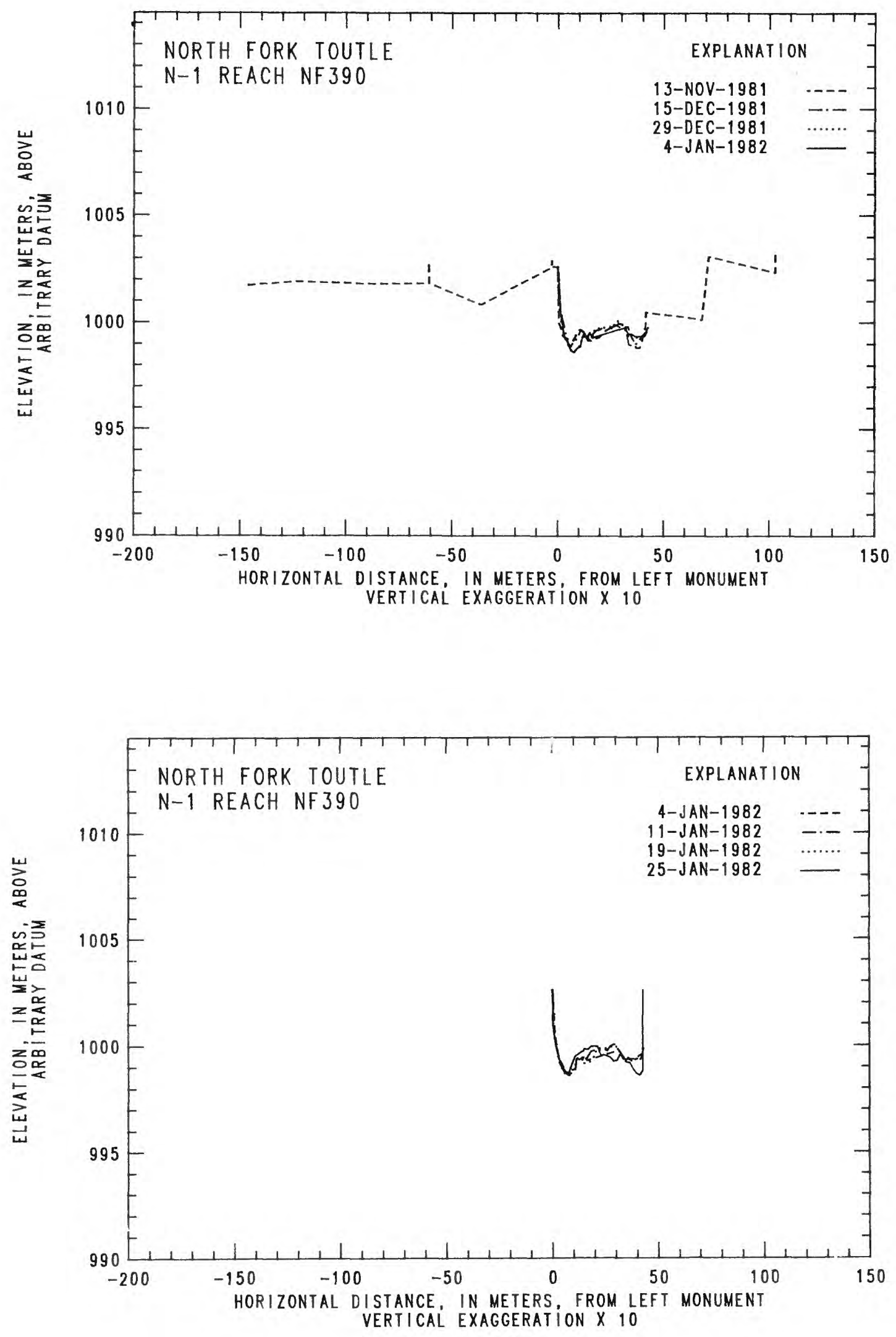

Figure 13.--Channel cross-section profiles for selected sites, North Fork Toutle River--Continued 

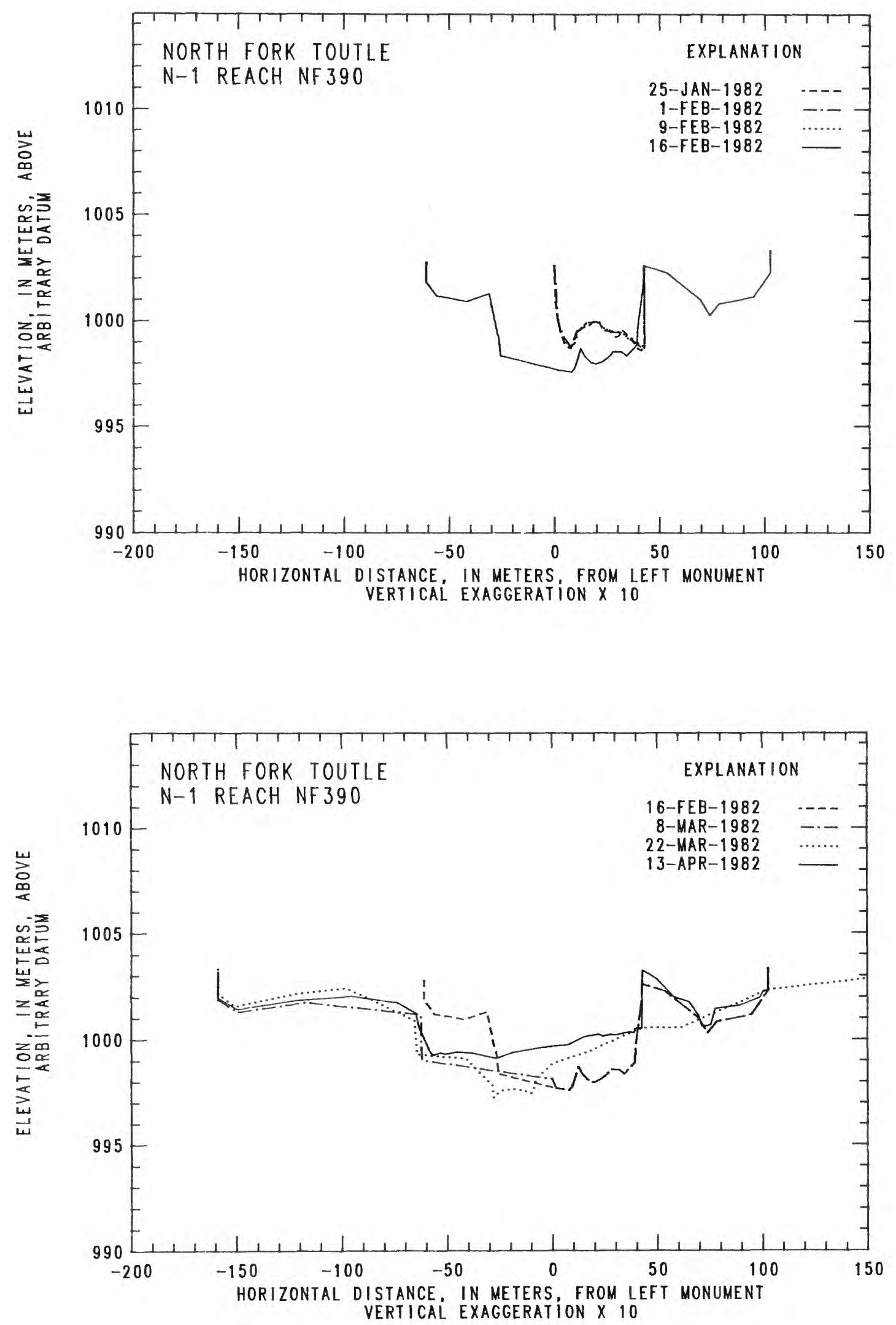

Figure 13.--Channel cross-section profiles for selected sites, North Fork Toutle River--Continued 

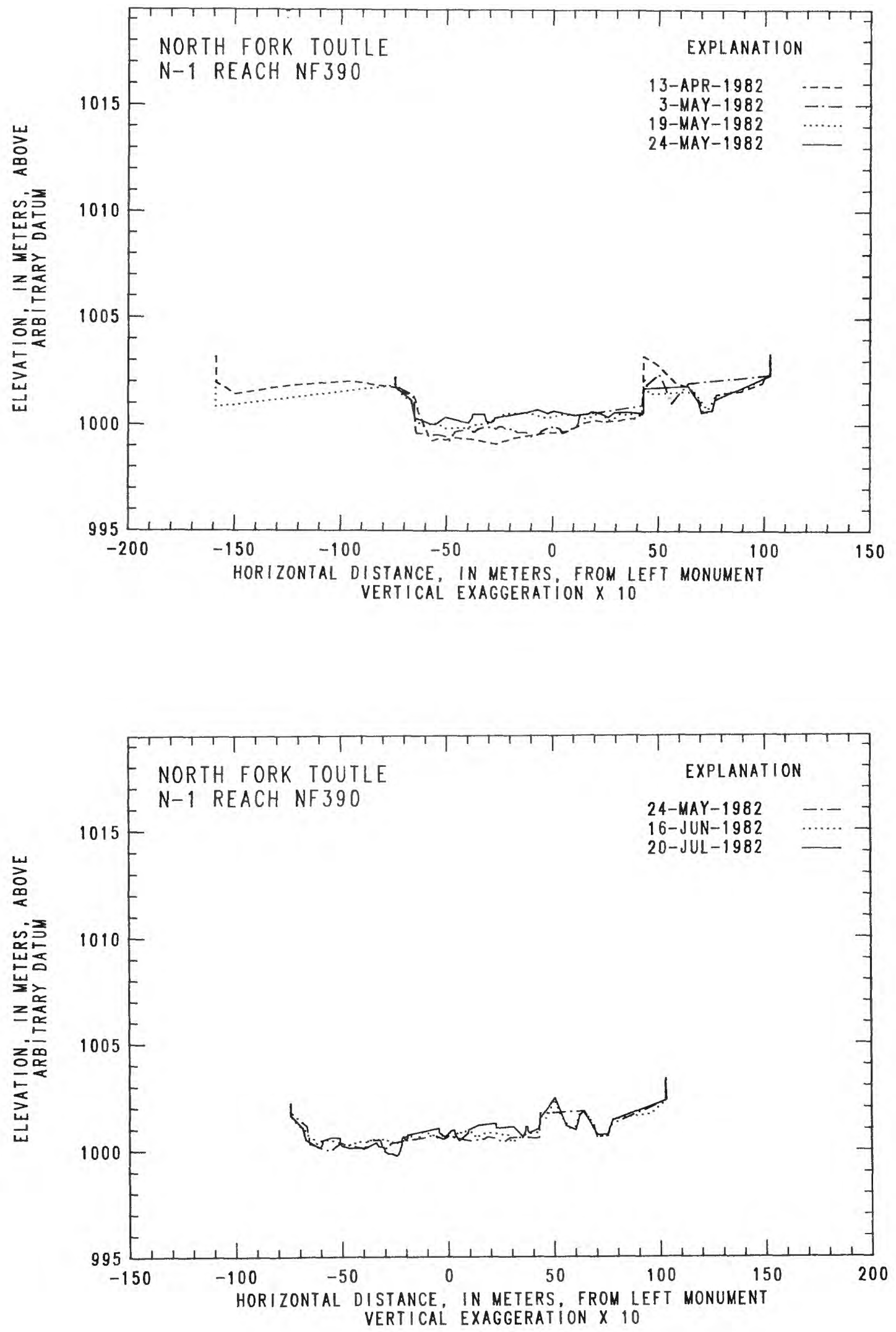

Figure 13.--Channel cross-section profiles for selected sites, North Fork Toutle River--Continued 
Multip1y SI units

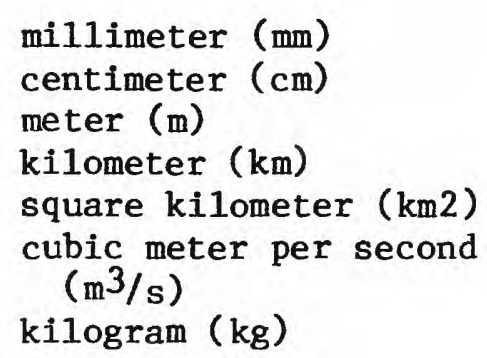

0.03937

0.3937

3.281

0.6214

0.3861

35.31

2.2046
To obtain inch-pound units

inch (in.)

inch (in.)

foot ( $f t$ )

mile (mi)

square mile $\left(\mathrm{mi}^{2}\right)$

cubic foot per second $\left(\mathrm{m}^{3} / \mathrm{s}\right)$

pound ( $1 \mathrm{~b}$ ) 

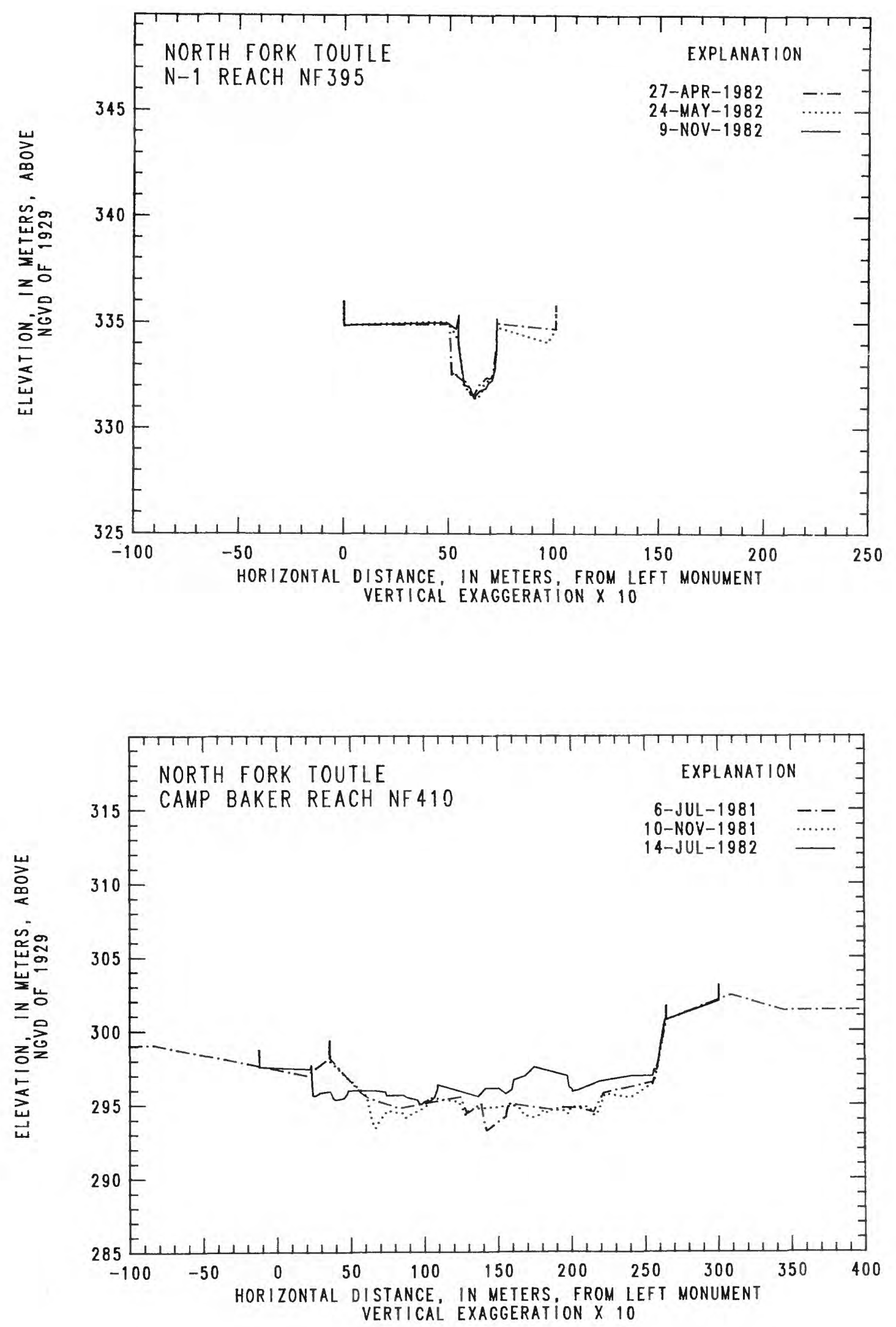

Figure 13.--Channel cross-section profiles for selected sites, North Fork Toutle River--Continued 

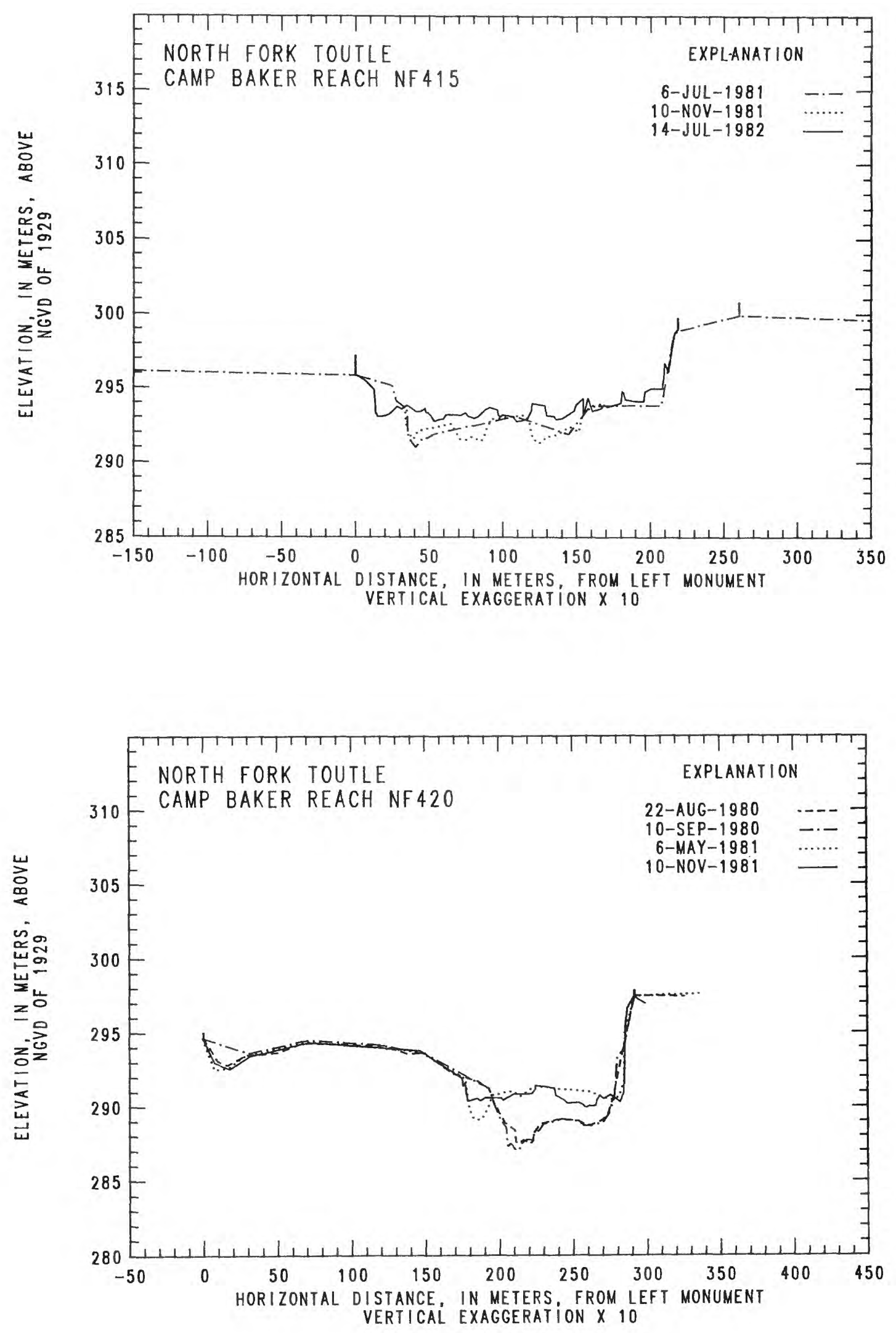

Figure 13.--Channel cross-section profiles for selected sites, North Fork Toutle River--Continued 

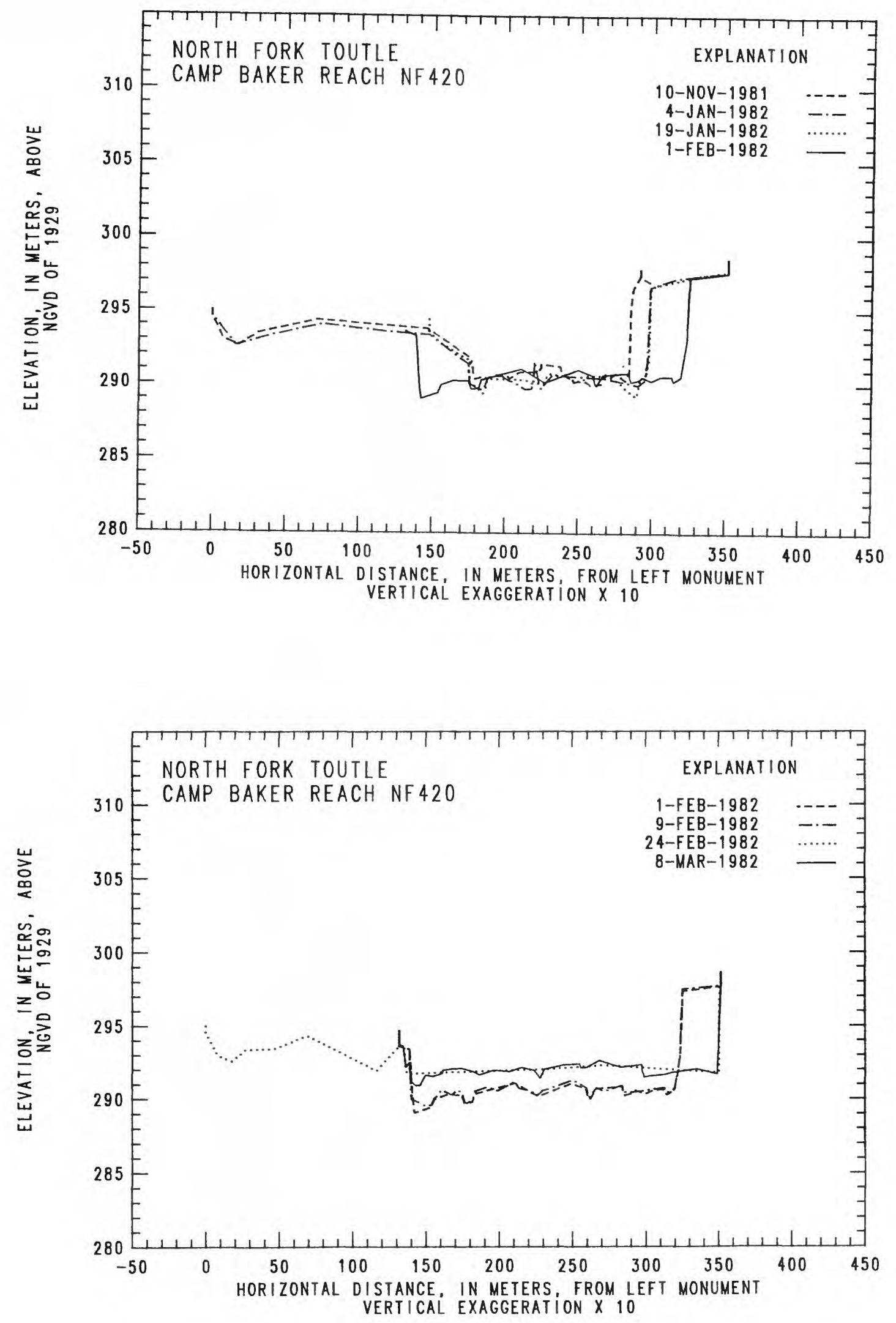

Figure 13.--Channel cross-section profiles for selected sites, North Fork Toutle River--Continued 

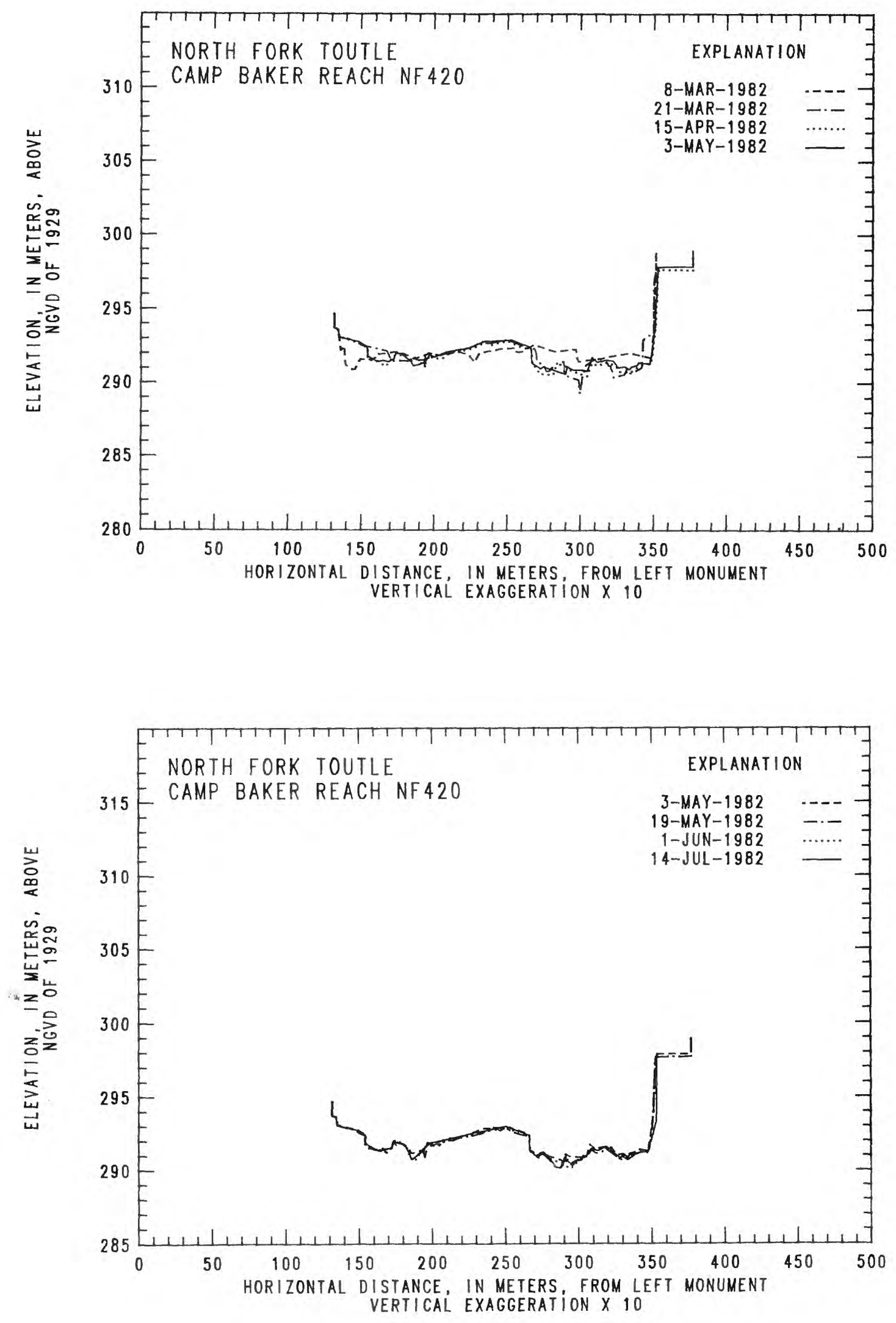

Figure 13.--Channel cross-section profiles for selected sites, North Fork Toutle River--Continued 

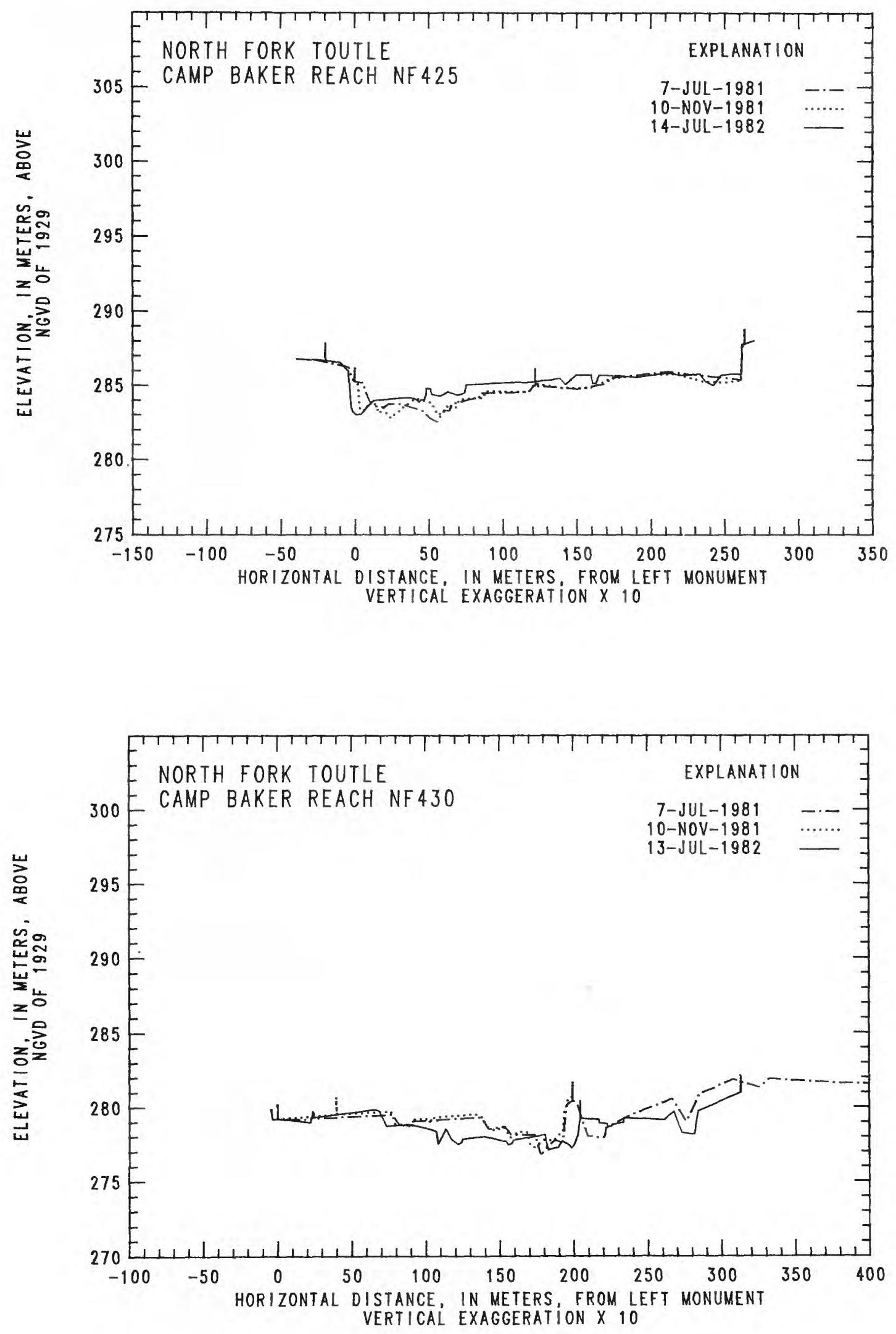

Figure 13.--Channel cross-section profiles for selected sites, North Fork Toutle River--Continued 

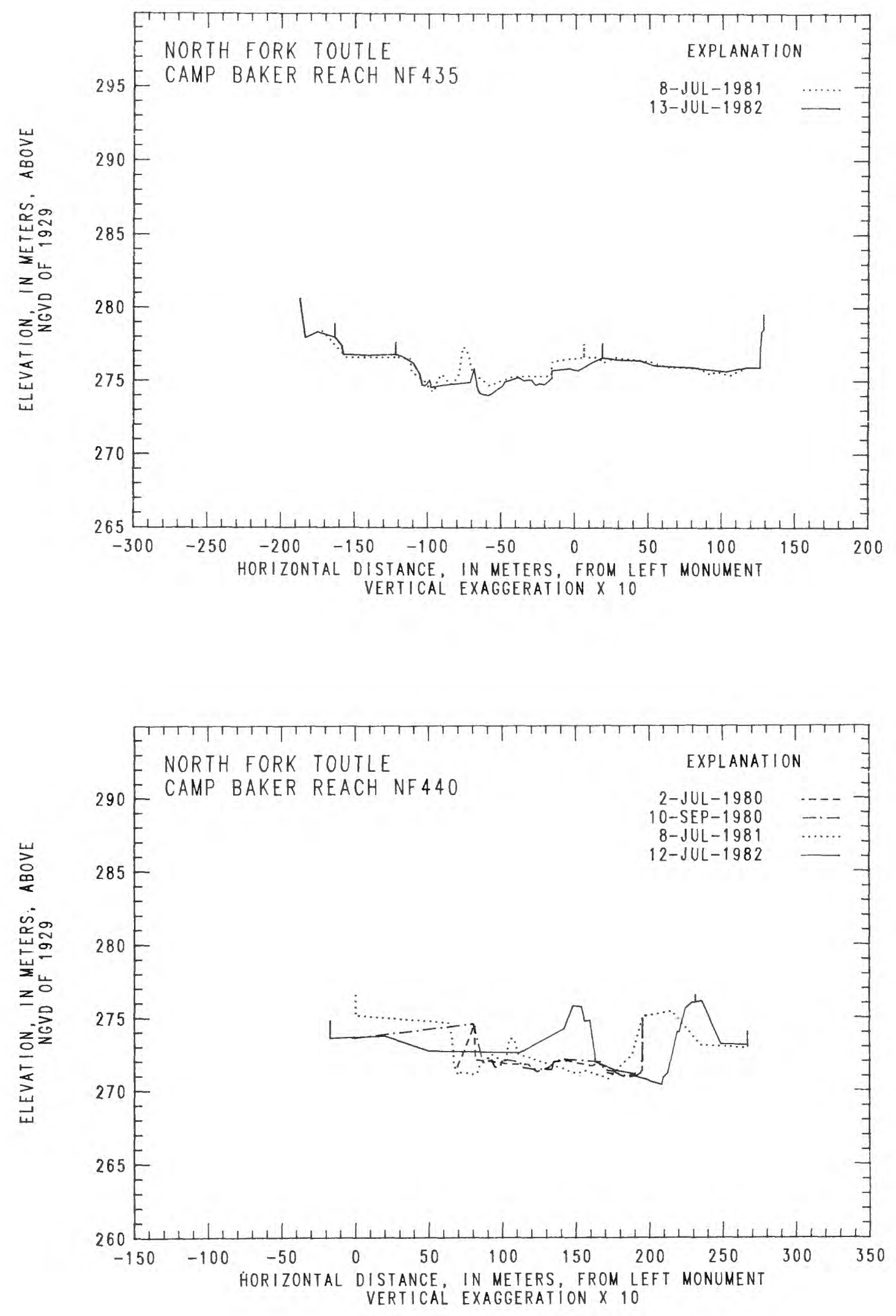

Figure 13.--Channel cross-section profiles for selected sites, North Fork Toutle River--Continued 

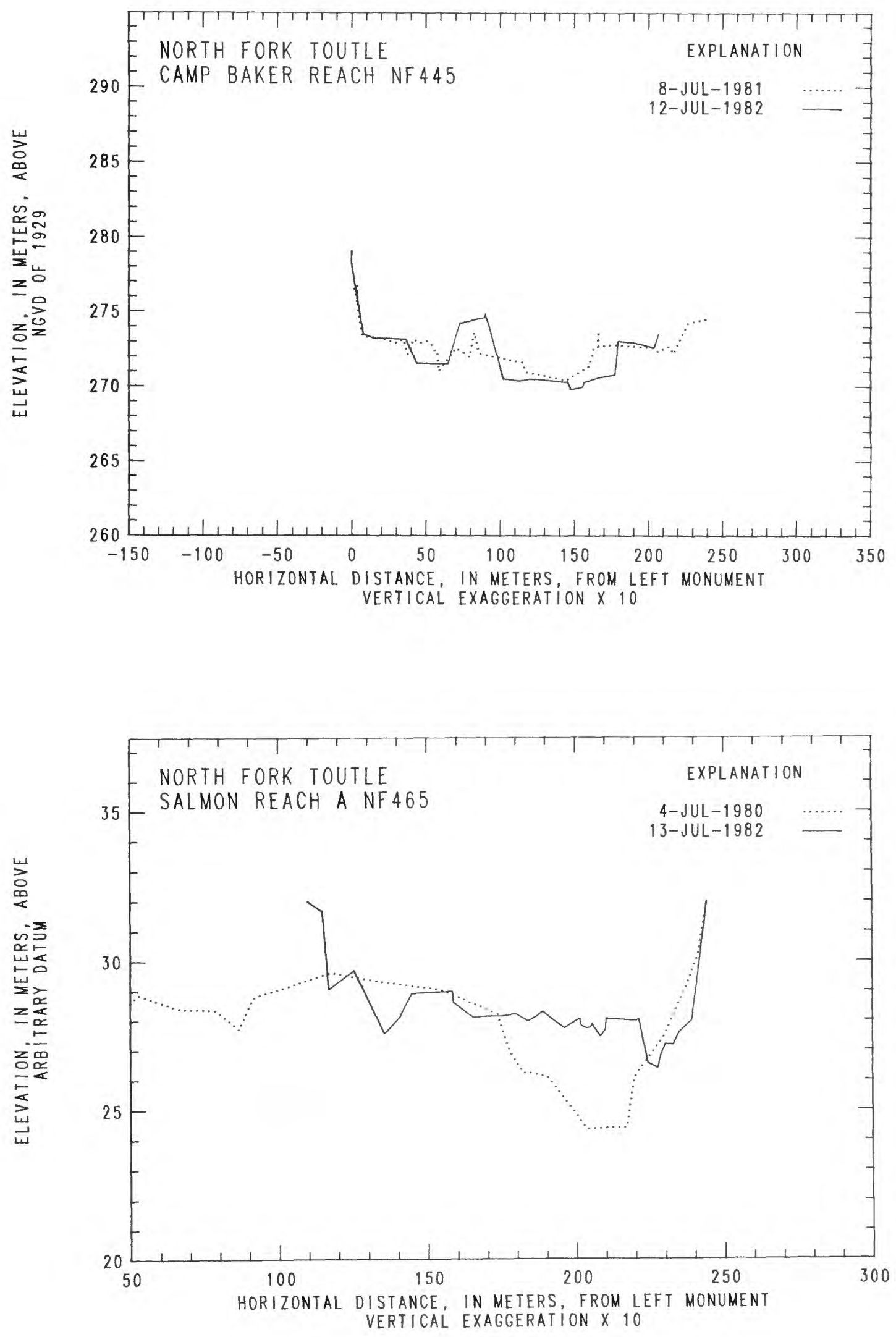

Figure 13.--Channel cross-section profiles for selected sites, North Fork Toutle River--Continued 

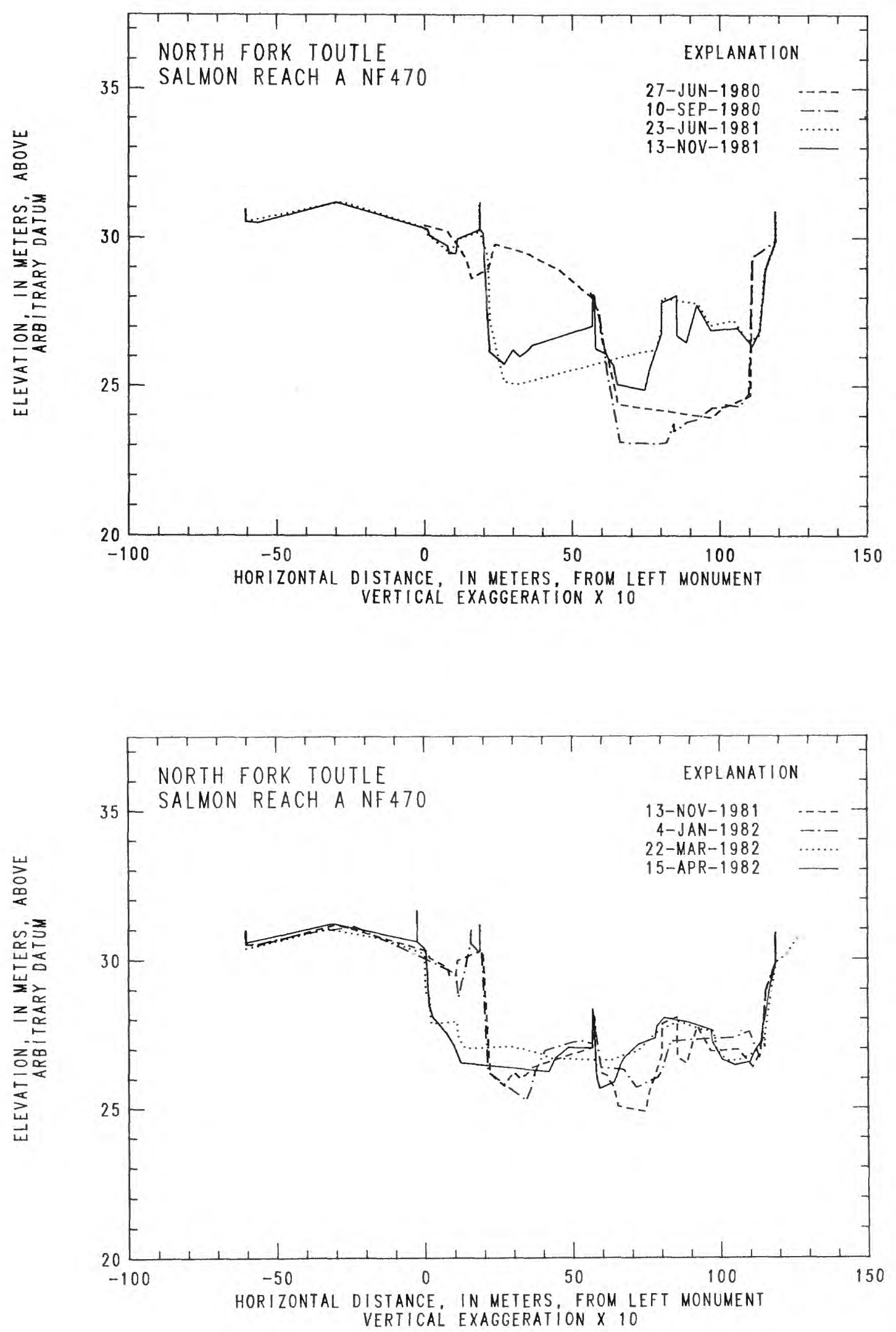

Figure 13.--Channel cross-section profiles for selected sites, North Fork Toutle River--Continued 

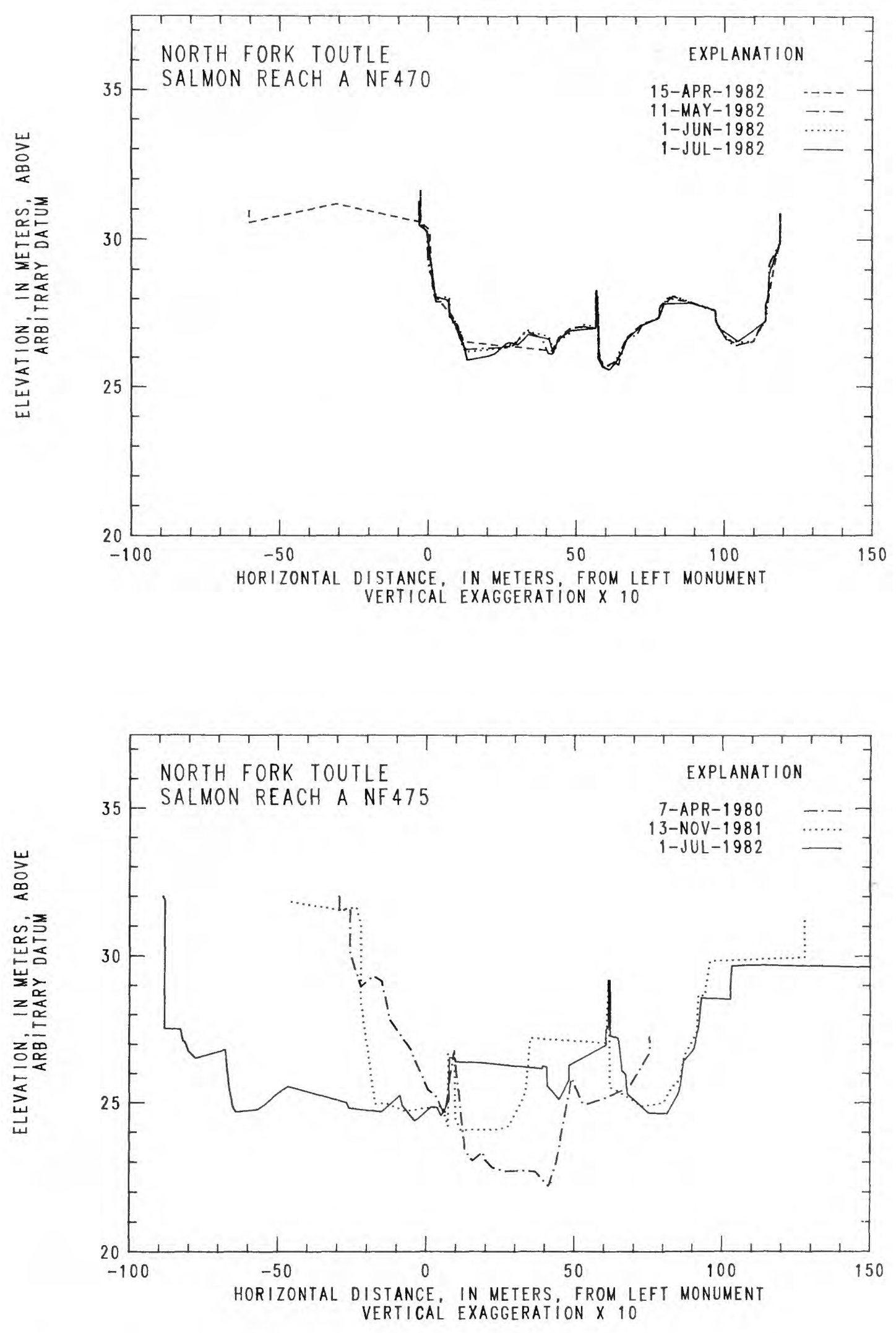

Figure 13.--Channel cross-section profiles for selected sites, North Fork Toutle River--Continued 

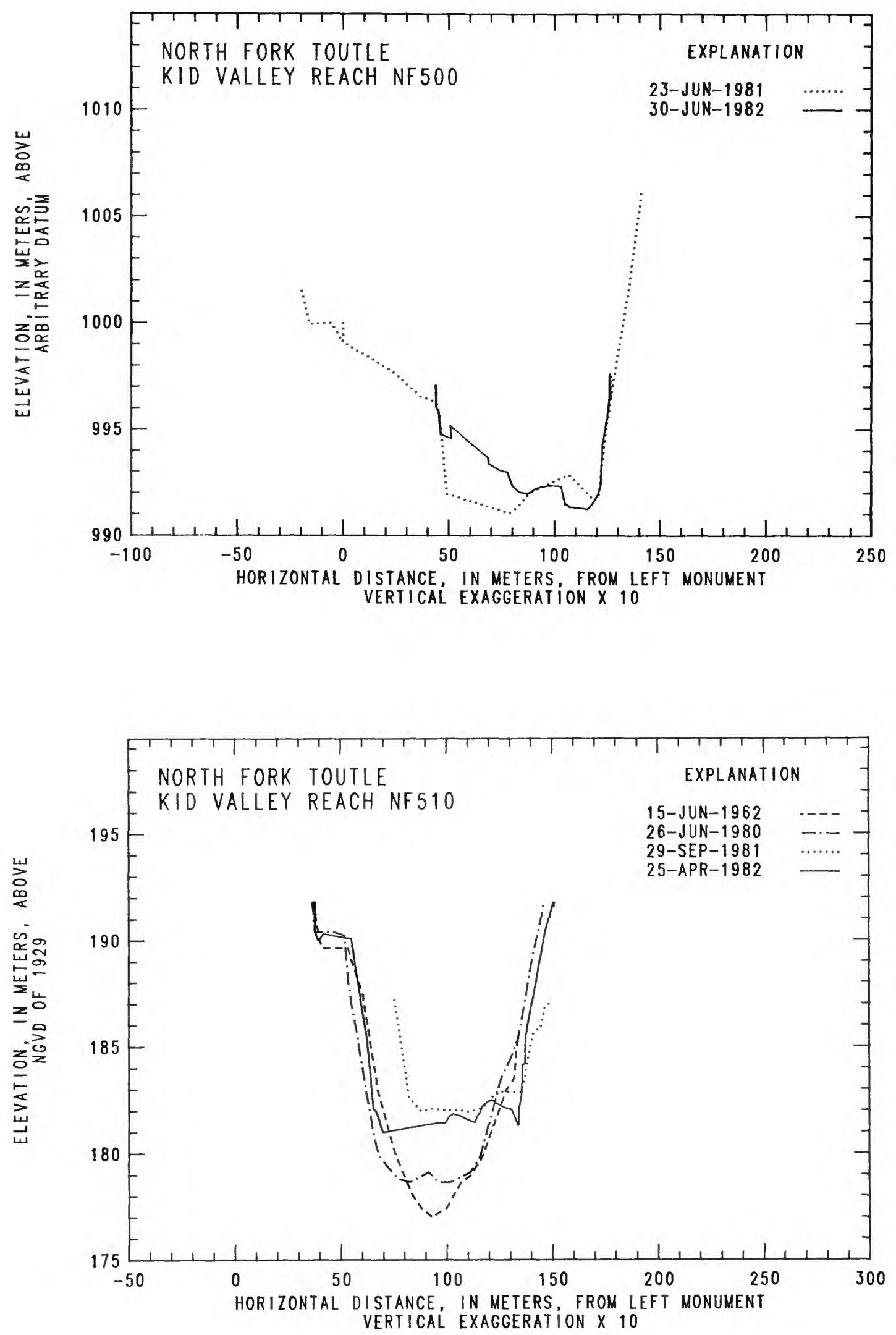

Figure 13.--Channel cross-section profiles for selected sites, North Fork Toutle River--Continued 
POST-ERUPTION CHANGES IN CHANNEL GEOMETRY

OF STREAMS IN THE TOUTLE RIVER DRAINAGE BASIN, 1980-82, MOUNT ST. HELENS, WASHINGTON

By D. F. Meyer, K. M. Nolan, and J. E. Dodge

\begin{abstract}
The May 18, 1980, eruption of Mount St. Helens, Washington, generated a debris avalanche, lateral blast, lahars, and tephra deposits that altered mainstem and tributary channels within the Toutle River drainage basin. Channel cross sections were monumented and surveyed on North Fork Toutle River and its tributaries, on South Fork Toutle River, on Green River, and on Toutle River in 1980 and 1981. These streams drain the north and west flanks of the volcano. The network of channel cross sections was surveyed more frequently following periods of higher flow. The repetitive cross-section surveys provide measurements of bank erosion or accretion and of channel erosion or aggradation. These data can be used to determine erosion rates, and to identify sources and storage sites of sediment in sediment budget computations. This report presents channel cross-section profiles constructed from the survey data collected during water years 1980 through 1982 .
\end{abstract}



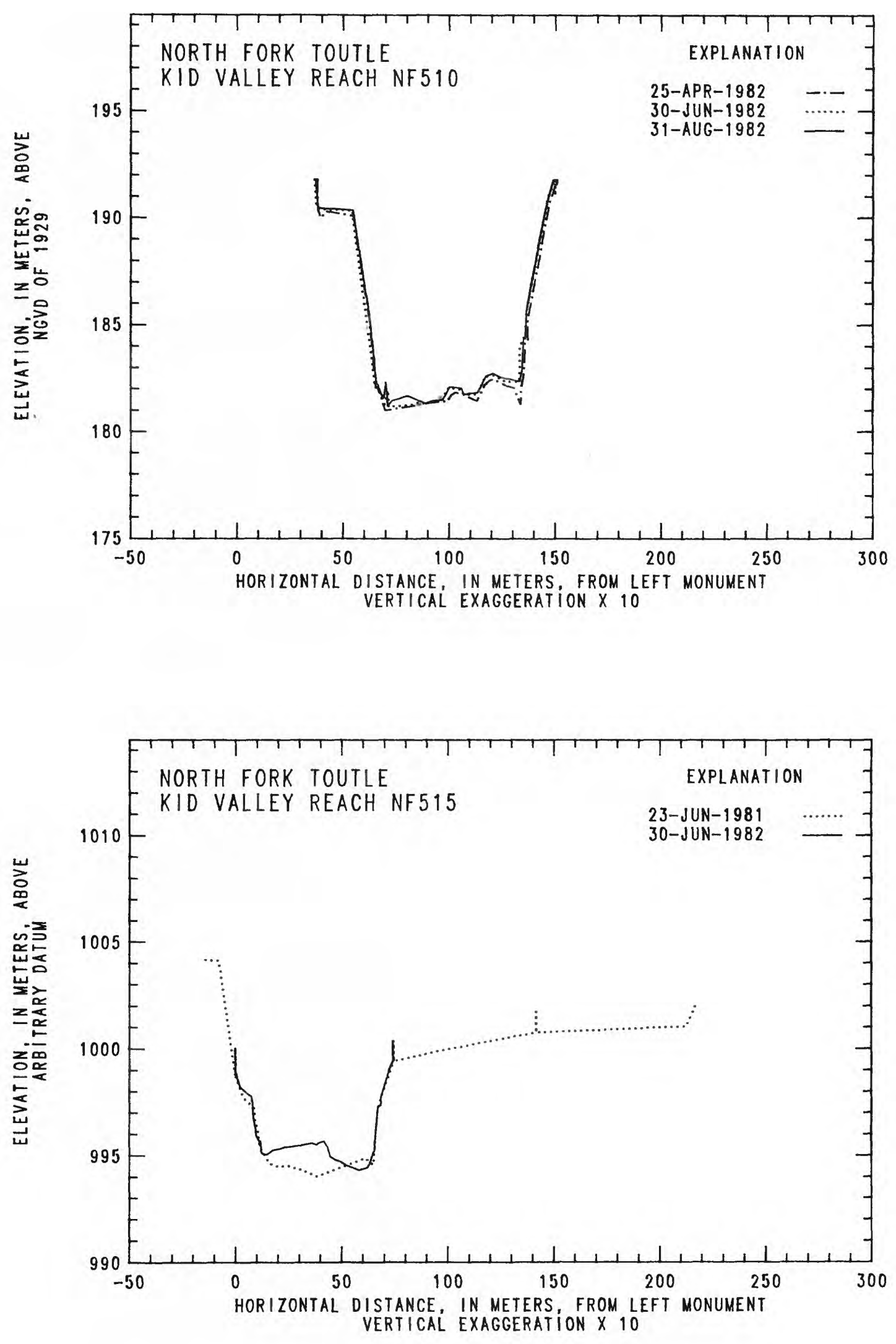

Figure 13.--Channel cross-section profiles for selected sites, North Fork Toutle River--Continued 

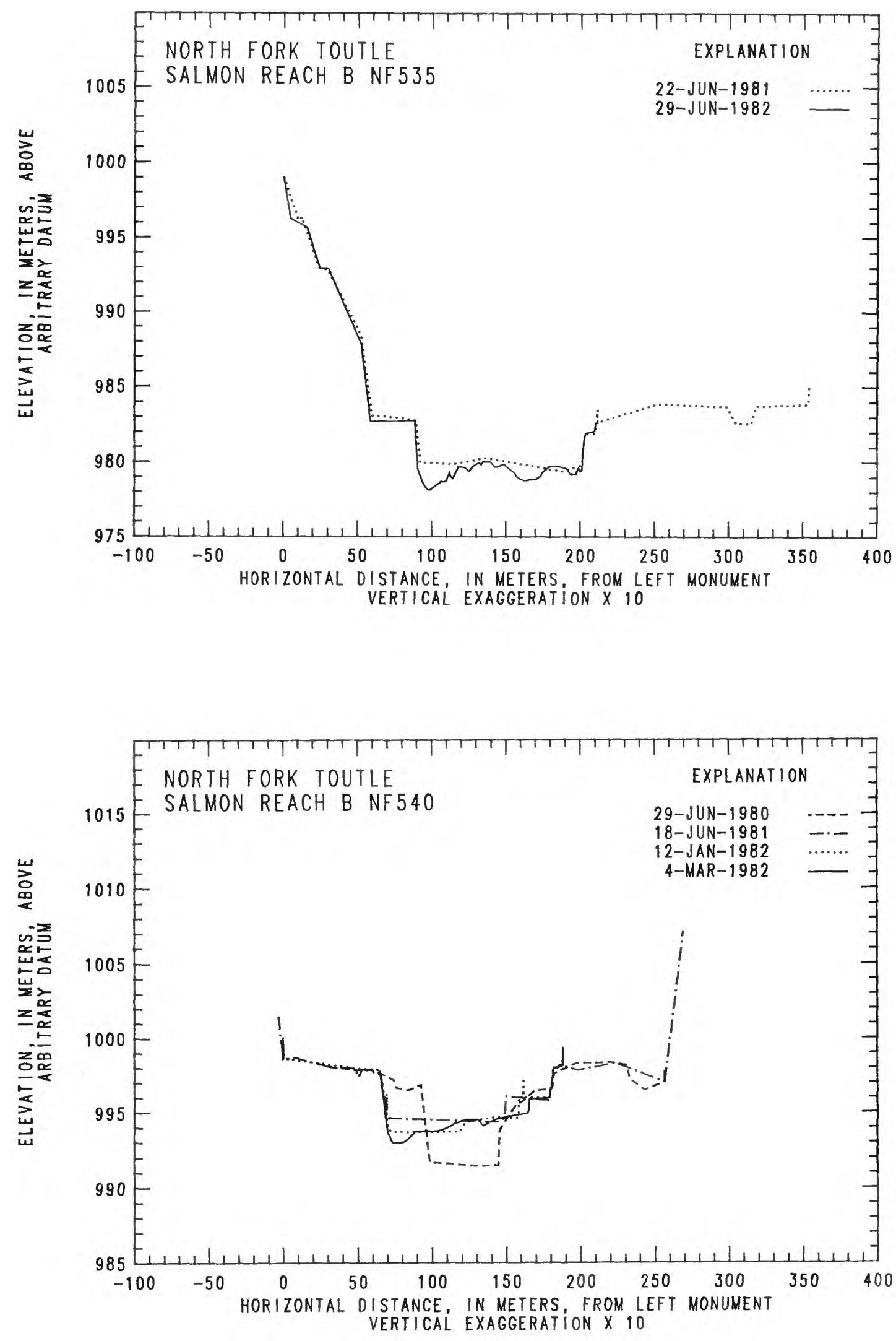

Figure 13.--Channel cross-section profiles for selected sites, North Fork Toutle River--Continued 

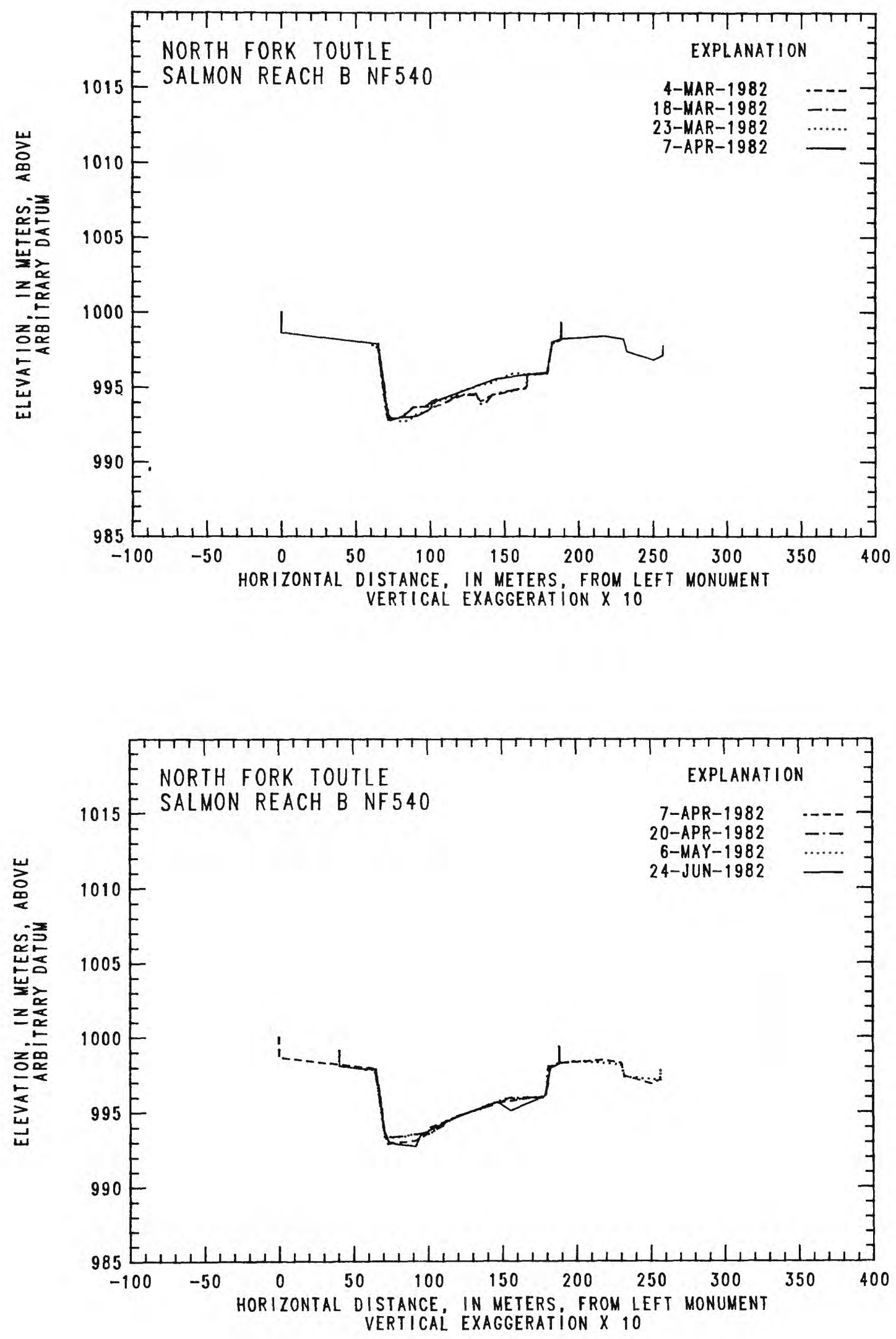

Figure 13.--Channel cross-section profiles for selected sites, North Fork Toutle River--Continued 

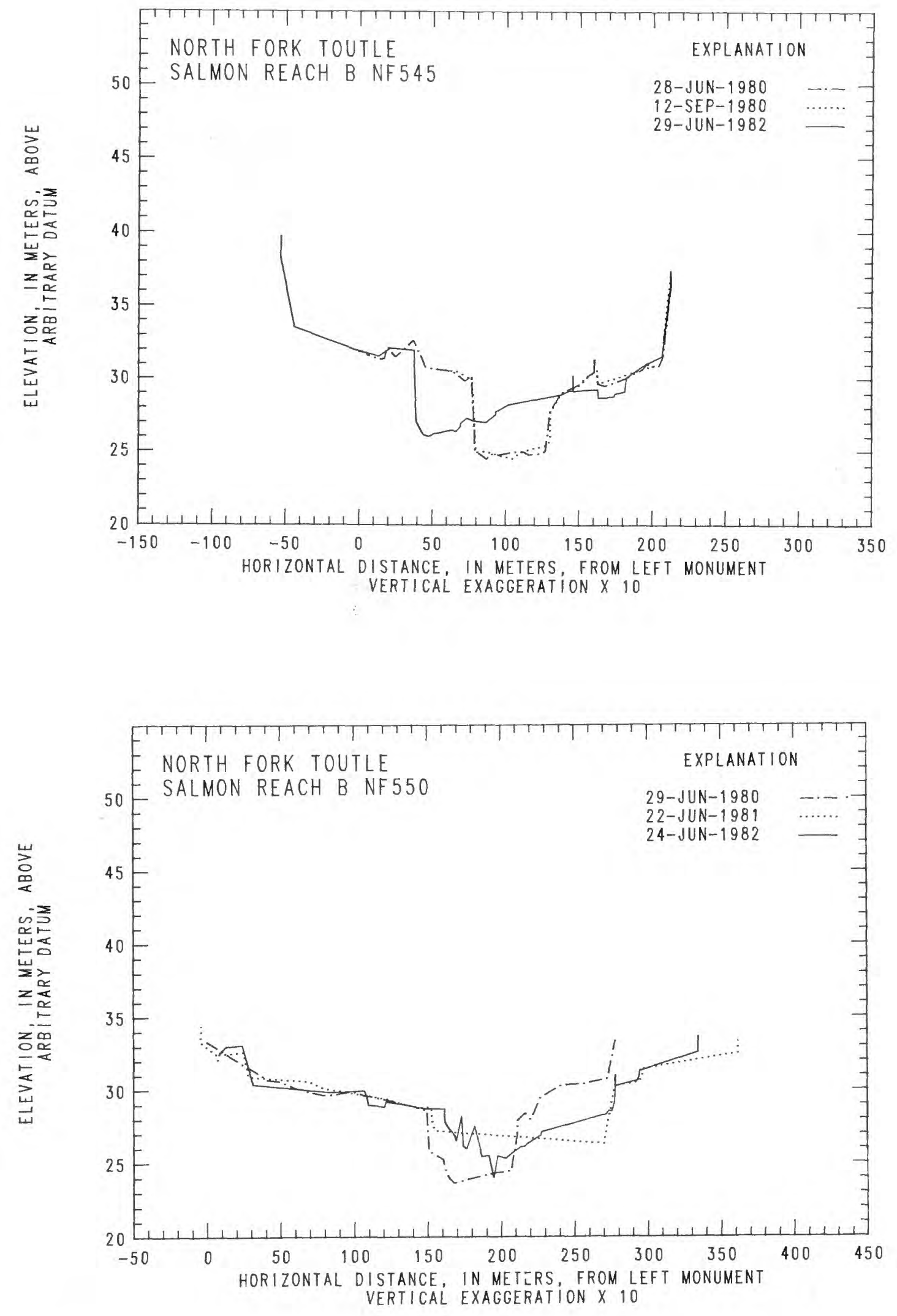

Figure 13.--Channel cross-section profiles for selected sites, North Fork Toutle River--Continued 

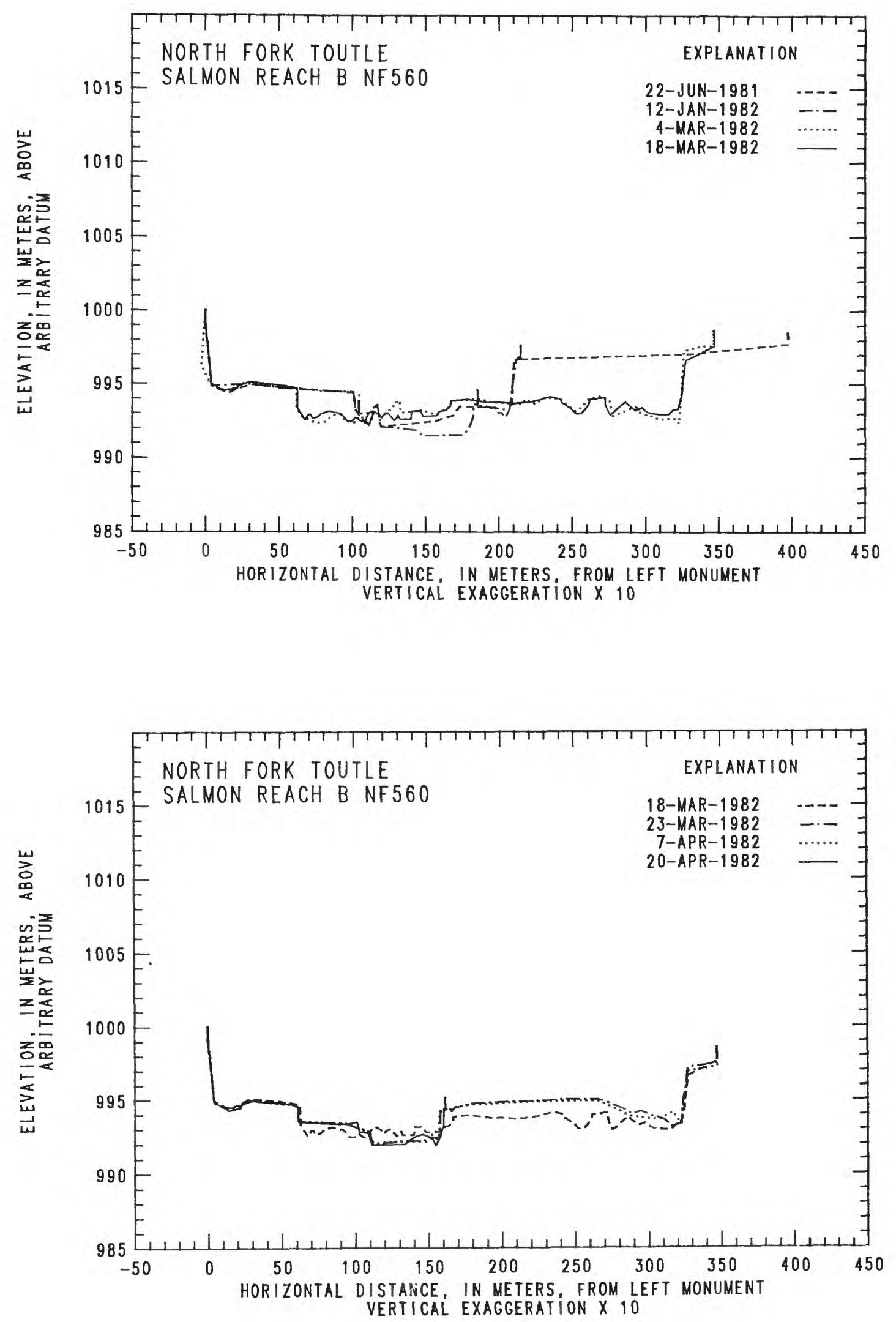

Figure 13.--Channel cross-section profiles for selected sites, North Fork Toutle River--Continued 

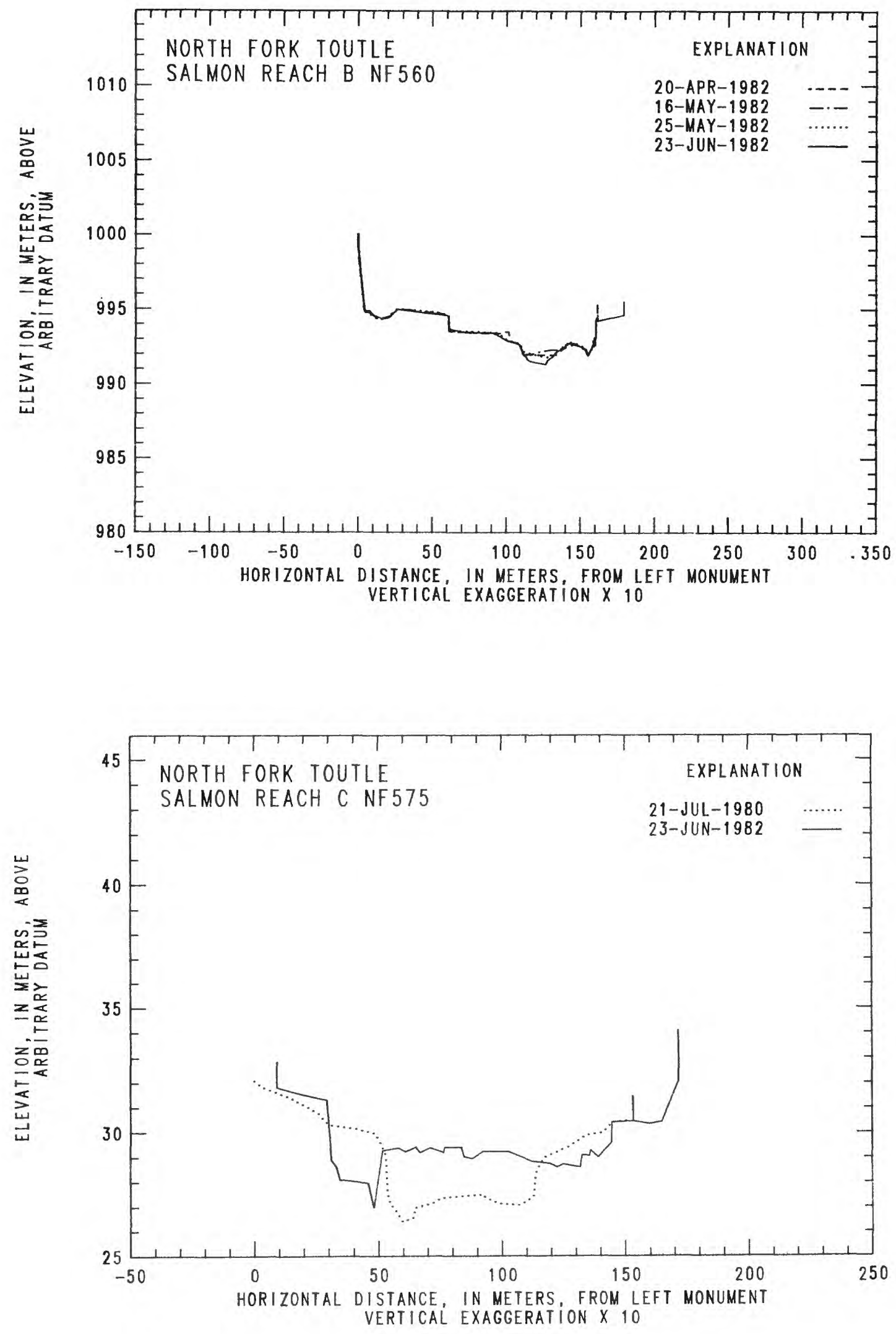

Figure 13.--Channel cross-section profiles for selected sites, North Fork Toutle River--Continued 

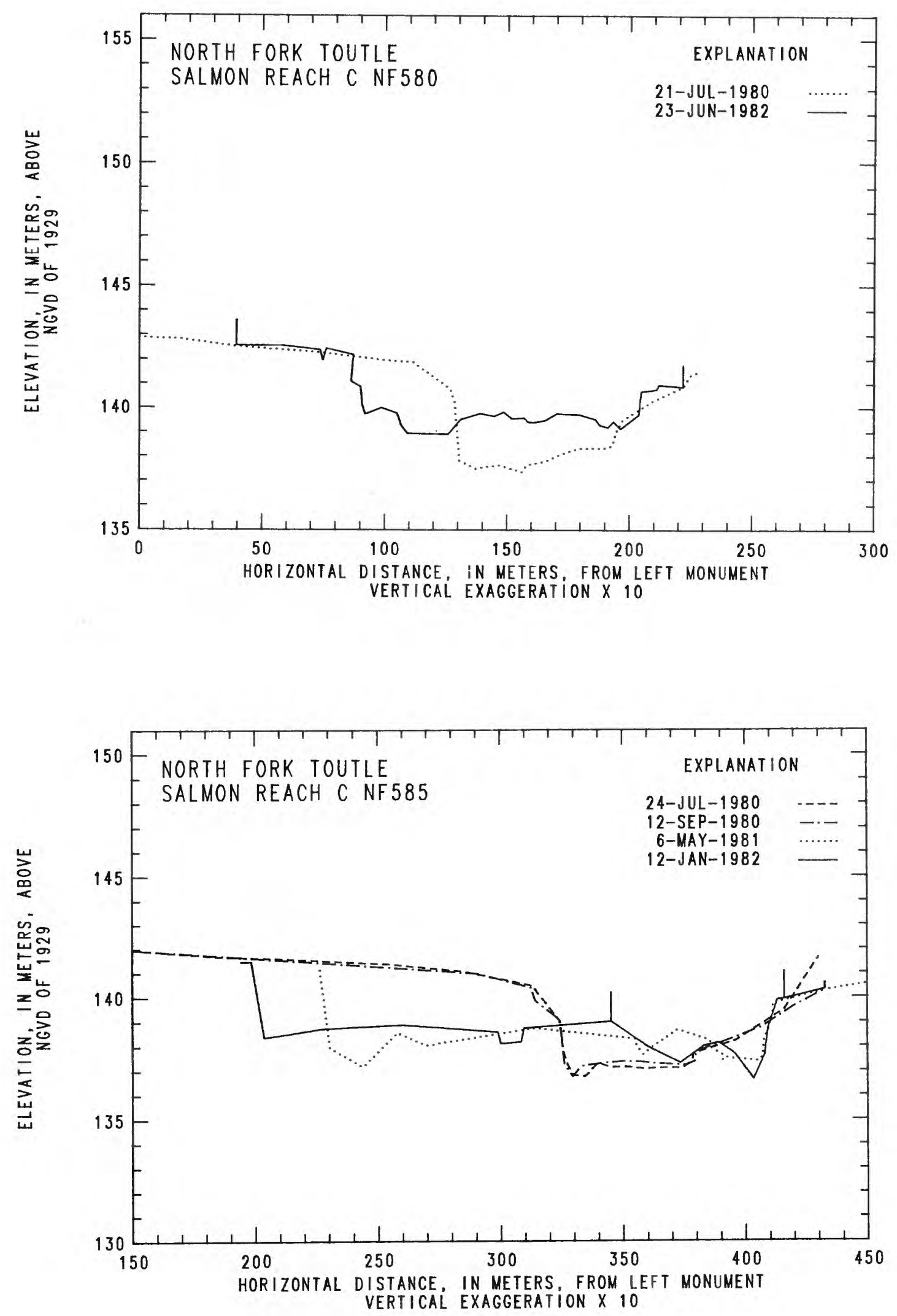

Figure 13.--Channel cross-section profiles for selected sites, North Fork Toutle River--Continued 

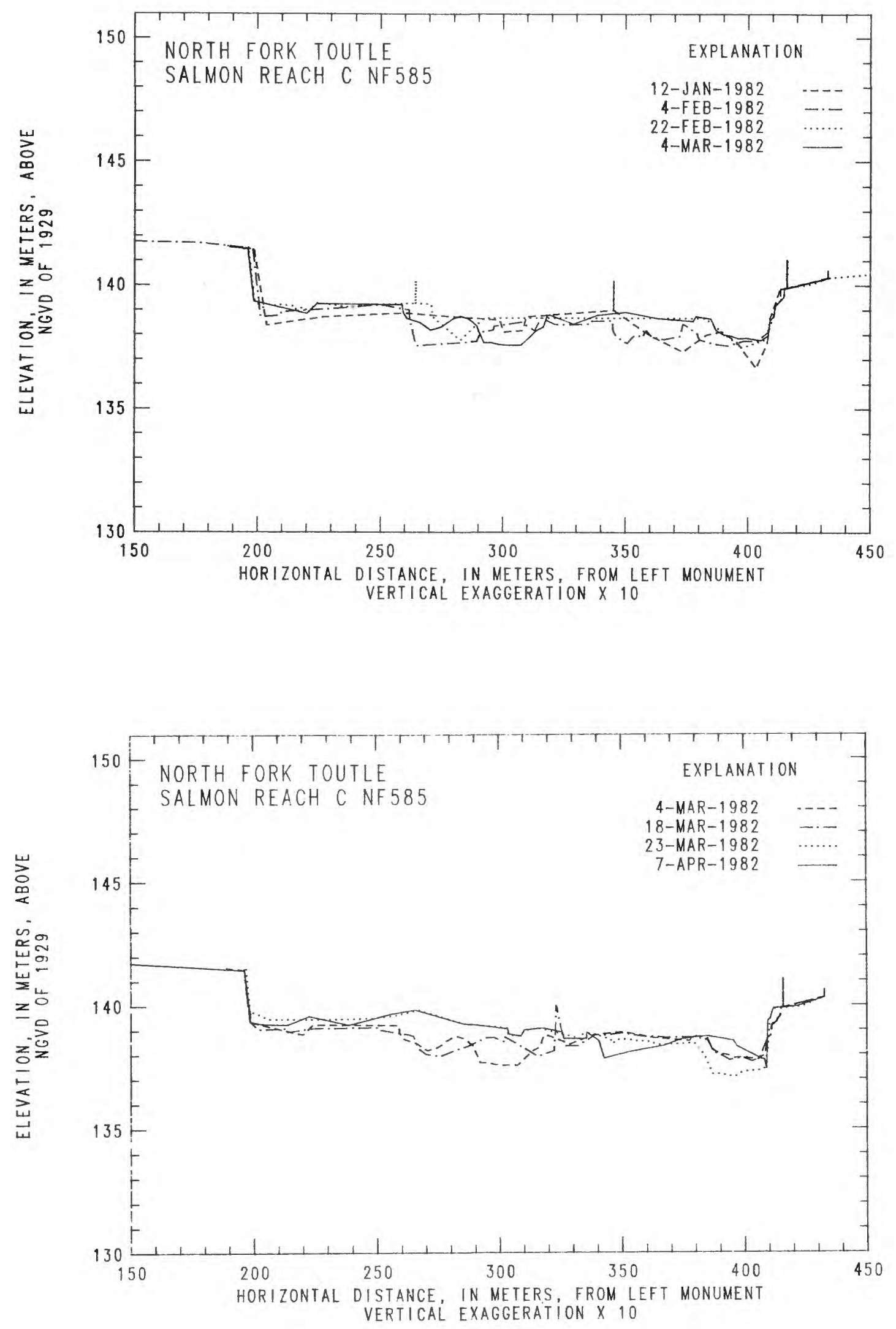

Figure 13.--Channel cross-section profiles for selected sites, North Fork Toutle River--Continued 

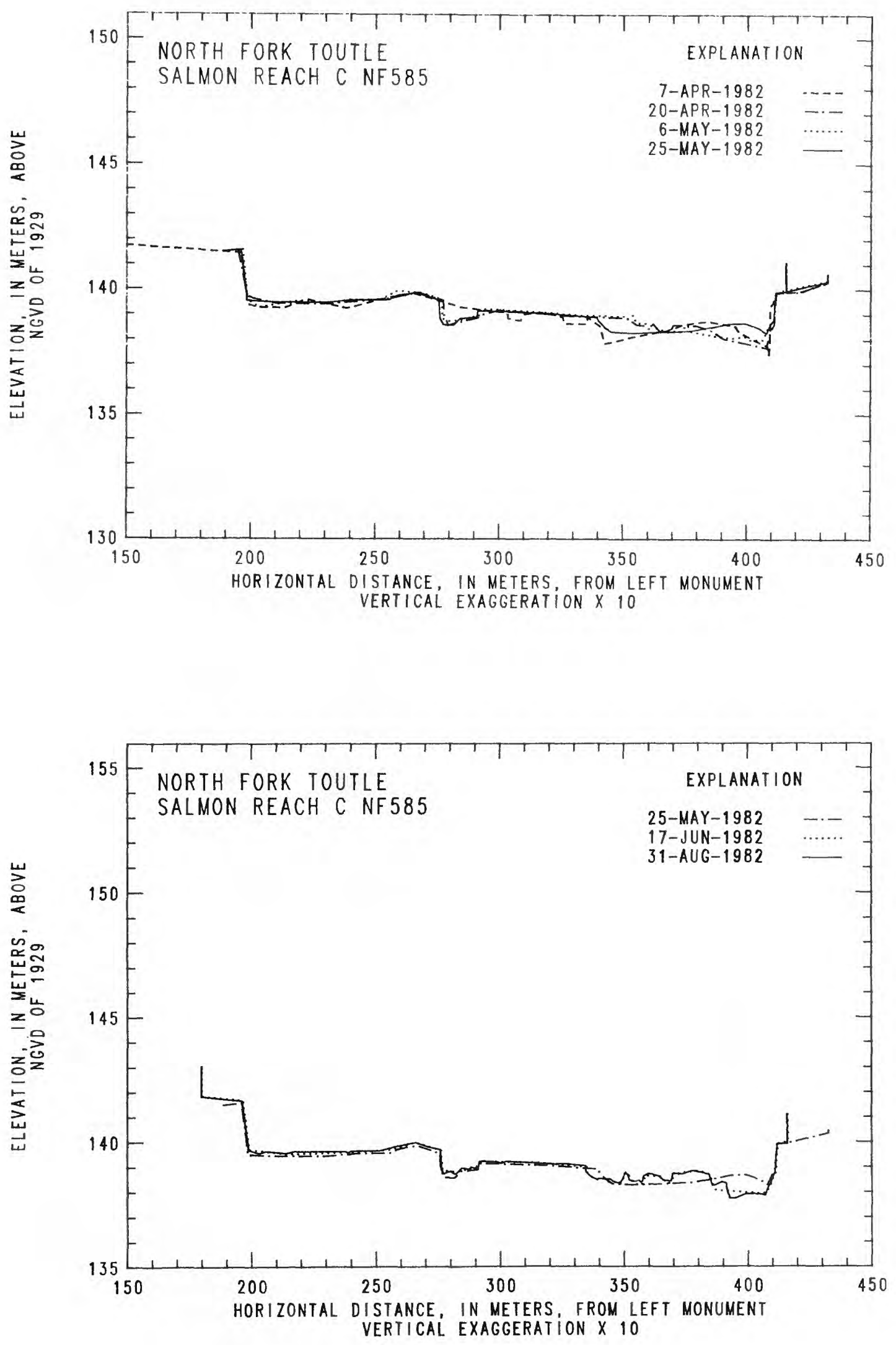

Figure 13.--Channel cross-section profiles for selected sites, North Fork Toutle River--Continued 


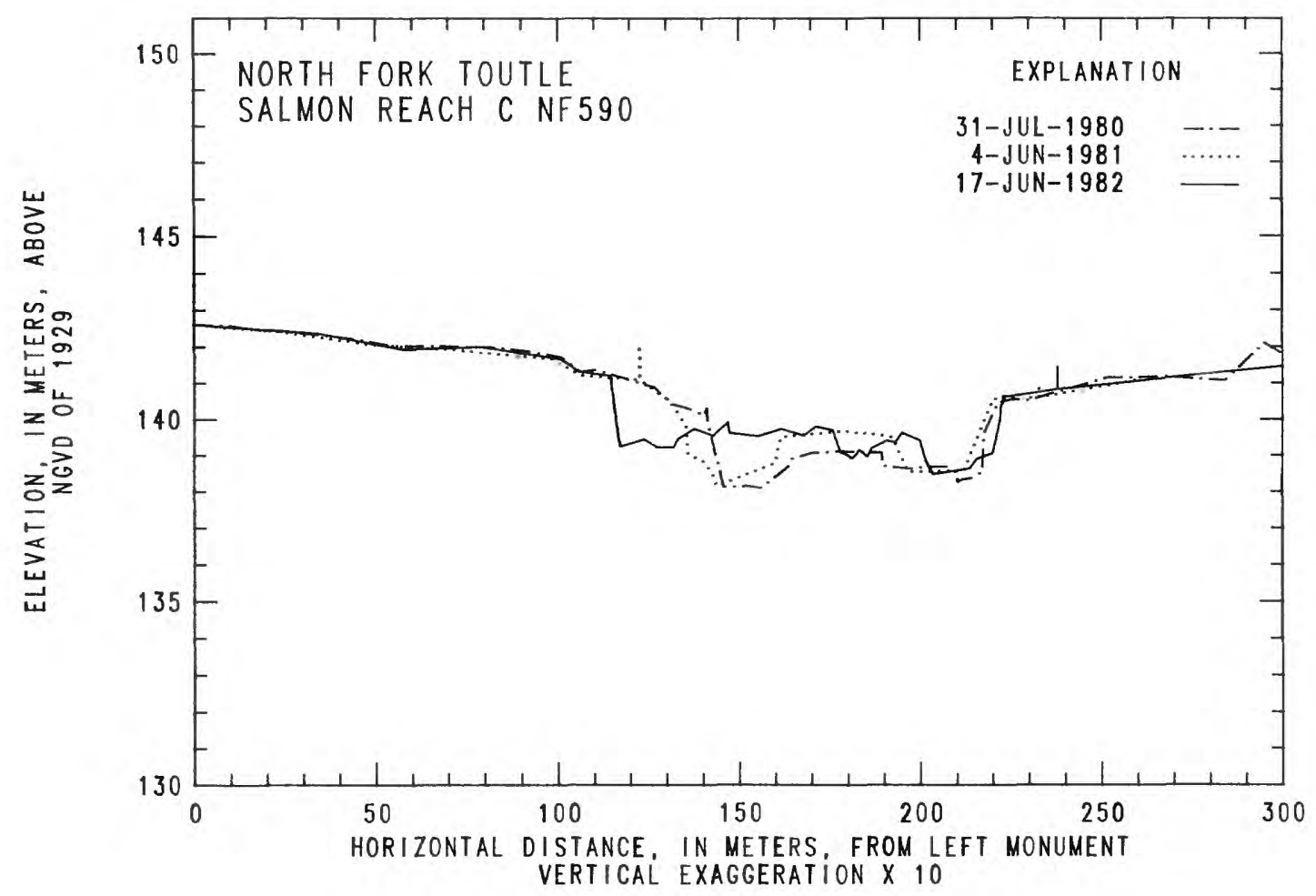

Figure 13.--Channel cross-section profiles for selected sites, North Fork Toutle River--Continued 


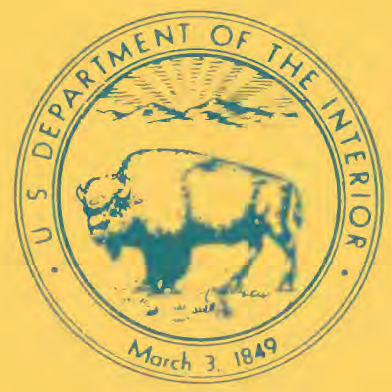

